Cochrane Database of Systematic Reviews

\title{
Sedation of children undergoing dental treatment (Review)
}

Ashley PF, Chaudhary M, Lourenço-Matharu L

Ashley PF, Chaudhary M, Lourenço-Matharu L.

Sedation of children undergoing dental treatment.

Cochrane Database of Systematic Reviews 2018, Issue 12. Art. No.: CD003877.

DOI: 10.1002/14651858.CD003877.pub5.

www.cochranelibrary.com 
TABLE OF CONTENTS

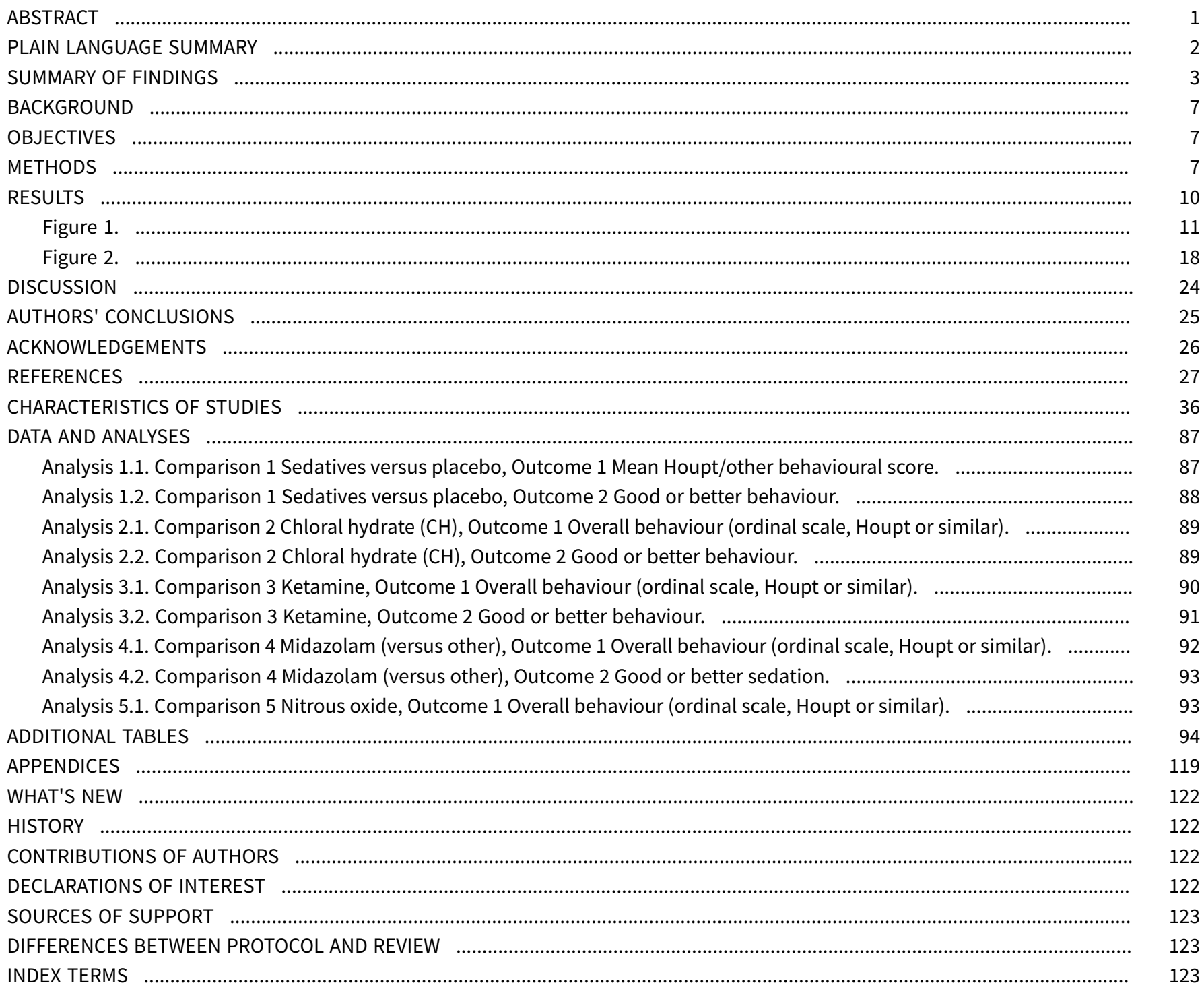


[Intervention Review]

\section{Sedation of children undergoing dental treatment}

Paul F Ashley ${ }^{1}$, Mohsin Chaudhary², Liege Lourenço-Matharu ${ }^{3}$

1Unit of Paediatric Dentistry, Department of Craniofacial Growth and Development, UCL Eastman Dental Institute, London, UK.

2Paediatrics, University College London Hospital, London, UK. ${ }^{3}$ London, UK

Contact: Paul F Ashley, Unit of Paediatric Dentistry, Department of Craniofacial Growth and Development, UCL Eastman Dental Institute, 256 Grays Inn Road, London, WC1X 8LD, UK. p.ashley@ucl.ac.uk.

Editorial group: Cochrane Oral Health Group.

Publication status and date: New search for studies and content updated (conclusions changed), published in Issue 12, 2018.

Citation: Ashley PF, Chaudhary M, Lourenço-Matharu L. Sedation of children undergoing dental treatment. Cochrane Database of Systematic Reviews 2018, Issue 12. Art. No.: CD003877. DOI: 10.1002/14651858.CD003877.pub5.

Copyright (c) 2018 The Cochrane Collaboration. Published by John Wiley \& Sons, Ltd.

\section{A B S T R A C T}

\section{Background}

Children's fear about dental treatment may lead to behaviour management problems for the dentist, which can be a barrier to the successful dental treatment of children. Sedation can be used to relieve anxiety and manage behaviour in children undergoing dental treatment. There is a need to determine from published research which agents, dosages and regimens are effective. This is the second update of the Cochrane Review first published in 2005 and previously updated in 2012.

\section{Objectives}

To evaluate the efficacy and relative efficacy of conscious sedation agents and dosages for behaviour management in paediatric dentistry.

\section{Search methods}

Cochrane Oral Health's Information Specialist searched the following databases: Cochrane Oral Health's Trials Register (to 22 February 2018); the Cochrane Central Register of Controlled Trials (CENTRAL; 2018, Issue 1) in the Cochrane Library (searched 22 February 2018); MEDLINE Ovid (1946 to 22 February 2018); and Embase Ovid (1980 to 22 February 2018). The US National Institutes of Health Ongoing Trials Register (ClinicalTrials.gov) and the World Health Organization International Clinical Trials Registry Platform were searched for ongoing trials. No restrictions were placed on the language or date of publication when searching the electronic databases.

\section{Selection criteria}

Studies were selected if they met the following criteria: randomised controlled trials of conscious sedation comparing two or more drugs/ techniques/placebo undertaken by the dentist or one of the dental team in children up to 16 years of age. We excluded cross-over trials.

\section{Data collection and analysis}

Two review authors independently extracted, in duplicate, information regarding methods, participants, interventions, outcome measures and results. Where information in trial reports was unclear or incomplete authors of trials were contacted. Trials were assessed for risk of bias. Cochrane statistical guidelines were followed.

\section{Main results}

We included 50 studies with a total of 3704 participants. Forty studies (81\%) were at high risk of bias, nine (18\%) were at unclear risk of bias, with just one assessed as at low risk of bias. There were 34 different sedatives used with or without inhalational nitrous oxide. Dosages, mode of administration and time of administration varied widely. Studies were grouped into placebo-controlled, dosage and head-tohead comparisons. Meta-analysis of the available data for the primary outcome (behaviour) was possible for studies investigating oral midazolam versus placebo only. There is moderate-certainty evidence from six small clinically heterogeneous studies at high or unclear risk of bias, that the use of oral midazolam in doses between $0.25 \mathrm{mg} / \mathrm{kg}$ to $1 \mathrm{mg} / \mathrm{kg}$ is associated with more co-operative behaviour compared 
to placebo; standardized mean difference (SMD) favoured midazolam (SMD 1.96, 95\% confidence interval (Cl) 1.59 to 2.33 , P $<0.0001$, $1^{2}=90 \%$; 6 studies; 202 participants). It was not possible to draw conclusions regarding the secondary outcomes due to inconsistent or inadequate reporting or both.

\section{Authors' conclusions}

There is some moderate-certainty evidence that oral midazolam is an effective sedative agent for children undergoing dental treatment. There is a need for further well-designed and well-reported clinical trials to evaluate other potential sedation agents. Further recommendations for future research are described and it is suggested that future trials evaluate experimental regimens in comparison with oral midazolam or inhaled nitrous oxide.

\section{PLAIN LANGUAGE SUMMARY}

\section{Sedation of children undergoing dental treatment}

\section{Review question}

The aim of this Cochrane Review was to find out which drugs used to sedate children during dental treatment were the most effective.

\section{Background}

Fear of the dentist may be expressed as unco-operative behaviour in children requiring dental treatment. Behaviour management problems can result in a child's tooth decay going untreated. While behavioural techniques play an important role in managing children, some children still find it difficult to co-operate with dental treatment and may require sedation. This review examined the effects of drugs to sedate a child whilst keeping them conscious.

\section{Study characteristics}

Authors from Cochrane Oral Health carried out this review and the evidence is up to date to 22 February 2018. A total of 50 randomised controlled trials were included with a total of 3704 participants. Within these studies 34 different sedatives were used, often with inhalational nitrous oxide as well. Dosages and delivery of these drugs varied widely. We grouped studies into those where drugs were compared to a placebo, where drugs were compared to other drugs or where different dosages of drugs were compared. Because all the studies were so different we could only carry out a meta-analysis for studies comparing oral midazolam to a placebo. The review showed that use of oral midazolam made patients more co-operative for dental treatment than a placebo drug. Where reported, adverse effects were few and minor.

\section{Key results}

Oral midazolam probably improves behaviour of children during dental treatment. We evaluated other sedatives but there is insufficient evidence to draw any conclusions.

\section{Certainty of the evidence}

There is some moderate-certainty evidence that midazolam administered in a drink of juice is effective. 
SUMMARY OF FINDINGS

\section{Summary of findings for the main comparison. Sedative compared to placebo for children needing dental care}

Sedative compared to placebo for children needing dental care

Patient or population: children needing dental care

Setting: hospital

Intervention: sedative

Comparison: placebo

\begin{tabular}{|c|c|c|c|c|c|c|}
\hline \multirow[t]{2}{*}{ Outcomes } & \multicolumn{2}{|c|}{$\begin{array}{l}\text { Anticipated absolute effects* }(95 \% \\
\mathrm{Cl})\end{array}$} & \multirow[t]{2}{*}{$\begin{array}{l}\text { Relative effect } \\
(95 \% \mathrm{CI})\end{array}$} & \multirow{2}{*}{$\begin{array}{l}\text { Number of par- } \\
\text { ticipants } \\
\text { (studies) }\end{array}$} & \multirow{2}{*}{$\begin{array}{l}\text { Certainty of } \\
\text { the evidence } \\
\text { (GRADE) }\end{array}$} & \multirow[t]{2}{*}{ Comments } \\
\hline & $\begin{array}{l}\text { Risk with place- } \\
\text { bo }\end{array}$ & $\begin{array}{l}\text { Risk with seda- } \\
\text { tive }\end{array}$ & & & & \\
\hline \multirow[t]{2}{*}{$\begin{array}{l}\text { Houpt/other behavioural } \\
\text { score - Midazolam (oral) } \\
\text { SD units: investigators } \\
\text { measure behaviour using } \\
\text { different scales - Higher val- } \\
\text { ues mean better behaviour }\end{array}$} & \multirow{2}{*}{\multicolumn{2}{|c|}{$\begin{array}{l}\text { The Houpt/other behavioural score in } \\
\text { the midazolam (oral) group was on } \\
\text { average } \mathbf{1 . 9 6} \text { SDs higher (1.59 higher } \\
\text { to } 2.33 \text { higher) than the placebo group }\end{array}$}} & - & $\begin{array}{l}202 \\
(6 \mathrm{RCTs})\end{array}$ & $\begin{array}{l}\oplus \oplus \oplus \odot \\
\text { MODERATE } 1\end{array}$ & $\begin{array}{l}\text { As a rule of thumb } 0.2 \text { SD represents a } \\
\text { small difference, } 0.5 \text { a moderate differ- } \\
\text { ence, and } 0.8 \text { a large difference } \\
\text { Adverse events: vomiting/hiccupping re- } \\
\text { ported in } 1 \text { study. Amnesia reported in } 1 \\
\text { study }\end{array}$ \\
\hline & & & & & & $\begin{array}{l}\text { Oral midazolam probably improves be- } \\
\text { haviour }\end{array}$ \\
\hline $\begin{array}{l}\text { Houpt/other behaviour- } \\
\text { al score - Midazolam (intra- } \\
\text { venous) }\end{array}$ & \multirow{2}{*}{\multicolumn{2}{|c|}{$\begin{array}{l}\text { The Houpt/other behavioural score in } \\
\text { the midazolam (intravenous) group } \\
\text { was on average } 1.21 \text { SDs higher ( } 0.24 \\
\text { higher to } 2.18 \text { higher) than the placebo } \\
\text { group }\end{array}$}} & - & $\begin{array}{l}20 \\
(1 \mathrm{RCT})\end{array}$ & $\begin{array}{l}\oplus \ominus \ominus \ominus \\
\text { VERY LOW1, } 2\end{array}$ & $\begin{array}{l}\text { As a rule of thumb } 0.2 \text { SD represents a } \\
\text { small difference, } 0.5 \text { a moderate differ- } \\
\text { ence, and } 0.8 \text { a large difference }\end{array}$ \\
\hline $\begin{array}{l}\text { SD units: investigators } \\
\text { measure behaviour using } \\
\text { different scales - Higher val- } \\
\text { ues mean better behaviour }\end{array}$ & & & & & & $\begin{array}{l}\text { No adverse events reported } \\
\text { Uncertain whether intravenous midazo- } \\
\text { lam improves behaviour }\end{array}$ \\
\hline \multirow{3}{*}{$\begin{array}{l}\text { Houpt/other behavioural } \\
\text { score - Nitrous oxide } \\
\text { SD units: investigators } \\
\text { measure behaviour using } \\
\text { different scales - Higher val- } \\
\text { ues mean better behaviour }\end{array}$} & \multirow{3}{*}{\multicolumn{2}{|c|}{$\begin{array}{l}\text { The Houpt/other behavioural score in } \\
\text { the nitrous oxide group was on aver- } \\
\text { age } \mathbf{0 . 6 9} \text { SDs higher ( } 0.13 \text { higher to } \\
1.26 \text { higher) than the placebo group }\end{array}$}} & - & $\begin{array}{l}52 \\
(1 \mathrm{RCT})\end{array}$ & $\begin{array}{l}\oplus \ominus \ominus \ominus \\
\text { VERY LOW } 1,3\end{array}$ & $\begin{array}{l}\text { As a rule of thumb } 0.2 \text { SD represents a } \\
\text { small difference, } 0.5 \text { a moderate differ- } \\
\text { ence, and } 0.8 \text { a large difference }\end{array}$ \\
\hline & & & & & & No adverse events reported \\
\hline & & & & & & $\begin{array}{l}\text { Uncertain whether nitrous oxide im- } \\
\text { proves behaviour }\end{array}$ \\
\hline
\end{tabular}




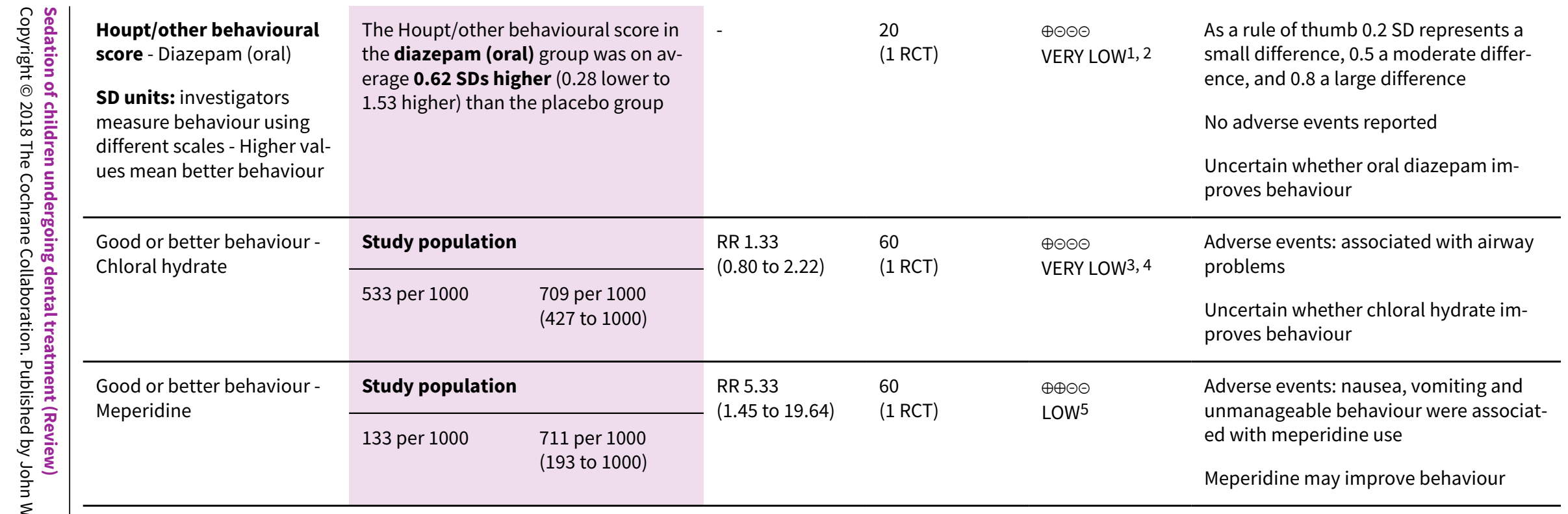

*The risk in the intervention group (and its $95 \% \mathrm{Cl}$ ) is based on the assumed risk in the comparison group and the relative effect of the intervention (and its $95 \% \mathrm{Cl}$ ).

Cl: confidence interval; RCT: randomised controlled trial; RR: risk ratio; SD: standard deviation; SMD: standardized mean difference.

GRADE Working Group grades of evidence

High certainty: we are very confident that the true effect lies close to that of the estimate of the effect.

Moderate certainty: we are moderately confident in the effect estimate: the true effect is likely to be close to the estimate of the effect, but there is a possibility that it is substantially different.

Low certainty: our confidence in the effect estimate is limited: the true effect may be substantially different from the estimate of the effect.

Very low certainty: we have very little confidence in the effect estimate: the true effect is likely to be substantially different from the estimate of effect.

1Downgraded for risk of bias (lack of blinding and randomisation processes unclear).

2Downgraded for imprecision (large confidence interval and small numbers).

3Downgraded for imprecision (large confidence interval).

4Downgraded for risk of bias (randomisation unclear and incomplete outcome assessment).

${ }^{5}$ Downgraded for risk of bias (randomisation unclear) and imprecision.

\section{Summary of findings 2 . Sedative compared with different dosage of the same sedative for children needing dental care}

\section{Sedative compared with different dosage of the same sedative for children needing dental care}

Patient or population: children needing dental care 
Intervention: sedative

Comparison: different dosage of the same sedative

\begin{tabular}{|c|c|c|c|}
\hline Outcomes & $\begin{array}{l}\text { Number of participants } \\
\text { (studies) }\end{array}$ & $\begin{array}{l}\text { Certainty of the evidence } \\
\text { (GRADE) }\end{array}$ & Comments \\
\hline $\begin{array}{l}\text { Any behavioural score - } \\
\text { Midazolam (any mode of } \\
\text { delivery) }\end{array}$ & $394(10)$ & $\begin{array}{l}\oplus \odot \odot \ominus \\
\text { VERY LOW } 1\end{array}$ & $\begin{array}{l}\text { There is insufficient evidence to determine whether any specific dose of intranasal } \\
\text { midazolam is effective } \\
\text { There is weak evidence from two trials that oral midazolam at a dose of } 0.5 \mathrm{mg} / \mathrm{kg} \\
\text { to } 0.75 \mathrm{mg} / \mathrm{kg} \text { is an effective sedative for children. However, one trial administered } \\
\text { both nitrous oxide and midazolam so it is difficult to attribute benefit to midazo- } \\
\text { lam alone }\end{array}$ \\
\hline $\begin{array}{l}\text { Any behavioural score - } \\
\text { Hydroxyzine }\end{array}$ & $30(1)$ & $\begin{array}{l}\oplus \ominus \ominus \ominus \\
\text { VERY LOW } 1\end{array}$ & $\begin{array}{l}\text { There is insufficient evidence to determine whether any specific dose of hydrox- } \\
\text { yzine is effective }\end{array}$ \\
\hline
\end{tabular}

\section{GRADE Working Group grades of evidence}

High certainty: we are very confident that the true effect lies close to that of the estimate of the effect.

Moderate certainty: we are moderately confident in the effect estimate: the true effect is likely to be close to the estimate of the effect, but there is a possibility that it is

substantially different.

Low certainty: our confidence in the effect estimate is limited: the true effect may be substantially different from the estimate of the effect.

Very low certainty: we have very little confidence in the effect estimate: the true effect is likely to be substantially different from the estimate of effect.

1Downgraded for risk of bias, inconsistency and/or imprecision.

Summary of findings 3 . Sedative compared with a different sedative for children needing dental care

\section{Sedative compared with a different sedative for children needing dental care}

Patient or population: children needing dental care

Setting: hospital

Intervention: sedative

Comparison: different sedative

\begin{tabular}{|c|c|c|c|}
\hline Outcomes & $\begin{array}{l}\text { Number of participants } \\
\text { (studies) }\end{array}$ & $\begin{array}{l}\text { Certainty of the evidence } \\
\text { (GRADE) }\end{array}$ & Comments \\
\hline $\begin{array}{l}\text { Any behavioural score - } \\
\text { Chloral hydrate/hydroxyzine versus }\end{array}$ & $235(6)$ & $\begin{array}{l}\oplus \ominus \ominus \ominus \\
\text { VERY LOW1 }\end{array}$ & \multirow{2}{*}{$\begin{array}{l}\text { No two studies evaluat- } \\
\text { ing the same intervention } \\
\text { and comparison found the } \\
\text { same effect. There is insuf- }\end{array}$} \\
\hline Any behavioural score - & $24(1)$ & $\oplus \ominus \odot \odot$ & \\
\hline
\end{tabular}


Dexmedetomidine versus

VERY LOW 1

\begin{tabular}{|c|c|c|}
\hline $\begin{array}{l}\text { Any behavioural score - } \\
\text { Ketamine versus }\end{array}$ & $494(8)$ & $\begin{array}{l}\oplus \ominus \odot \odot \\
\text { VERY LOW1 }\end{array}$ \\
\hline $\begin{array}{l}\text { Any behavioural score - } \\
\text { Ketamine/midazolam versus }\end{array}$ & $27(1)$ & $\begin{array}{l}\oplus \ominus \odot \odot \\
\text { VERY LOW } 1\end{array}$ \\
\hline $\begin{array}{l}\text { Any behavioural score - } \\
\text { Midazolam (oral) versus }\end{array}$ & $654(7)$ & $\begin{array}{l}\oplus \ominus \odot \ominus \\
\text { VERY LOW } 1\end{array}$ \\
\hline $\begin{array}{l}\text { Any behavioural score - } \\
\text { Midazolam (intravenous) versus }\end{array}$ & $70(2)$ & $\begin{array}{l}\oplus \ominus \ominus \ominus \\
\text { VERY LOW } 1\end{array}$ \\
\hline Any behavioural score - Midazolam (rectal) versus & $90(1)$ & $\begin{array}{l}\oplus \ominus \ominus \ominus \\
\text { VERY LOW } 1\end{array}$ \\
\hline $\begin{array}{l}\text { Any behavioural score - } \\
\text { Sevoflurane versus }\end{array}$ & $1140(3)$ & $\begin{array}{l}\oplus \ominus \odot \odot \\
\text { VERY LOW } 1\end{array}$ \\
\hline
\end{tabular}

\section{GRADE Working Group grades of evidence}

High certainty: we are very confident that the true effect lies close to that of the estimate of the effect.

Moderate certainty: we are moderately confident in the effect estimate: the true effect is likely to be close to the estimate of the effect, but there is a possibility that it is substantially different.

Low certainty: our confidence in the effect estimate is limited: the true effect may be substantially different from the estimate of the effect.

Very low certainty: we have very little confidence in the effect estimate: the true effect is likely to be substantially different from the estimate of effect.

1Downgraded for risk of bias, inconsistency and/or imprecision. 


\section{B A C K G R O U N D}

\section{Description of the condition}

Dental decay is one of the most common human diseases and affects almost $100 \%$ of adults and $60 \%$ to $90 \%$ of school children across the world (WHO 2012). This decay in children is often untreated. In 2015, 25\% of 5-year olds in England had teeth affected by dental decay with each of these children having on average three teeth damaged. Only $12 \%$ of these damaged teeth were filled (NDEP 2015). This represents a significant problem, if dentine caries is left it will usually lead to pain and sepsis which can often only be managed by extraction or extensive restoration of the affected teeth. Historically this has been managed in children by use of general anaesthetic. Whilst a proportion of children will always require this process, it is now recognised that it should be avoided wherever possible due to the associated rare risk of death. General anaesthesia is also very costly, it requires the use of specialist facilities and staff such as anaesthetists and specialist nurses.

The obvious alternative is to provide treatment under local anaesthesia, however some children will not be able to accept to this. Barriers to treatment may be dental fear or behaviour management problems (BMP). Estimates of the prevalence of dental fear and BMP are hard to find, however one Swedish study reported a value of $10.5 \%$ of children with BMP out of a population of 4 to 11-year olds (Klingberg 1994). Dental fear and BMP are closely related phenomena. Dental fear or anxiety is associated with increased levels of caries and BMP, however not all children who are dentally anxious will present with BMP, one study reported that only $60 \%$ of children with dental fear presented with BMP (Klingberg 1995). In turn, children exhibiting BMP may also be dentally anxious, though in the same study only $25 \%$ of those children with BMP were dentally anxious.

Methods of managing anxiety and behaviour are therefore required to meet this need. Whilst behavioural techniques that do not involve the use of drugs can play an important part in a child's management, many children will still find it difficult to tolerate dental treatment. In these cases sedation could be considered as a method for reducing anxiety and facilitating the provision of dental treatment.

\section{Description of the intervention}

Views of what constitutes sedation differ between clinicians, however any definition should seek to differentiate sedation from general anaesthetic. Unfortunately many sedative agents can also act as general anaesthetics and the difference in dose required to move from a sedated patient to an anaesthetised patient can be very small and extremely variable between patients. The ideal sedative agent would reduce anxiety and improve behaviour thus facilitating the completion of dental treatment and providing a positive experience for the patient. It could be carried out safely in the primary care sector and have a wide margin of safety. For the purposes of this review, therefore, a widely used definition of sedation will be followed which clearly states the level of consciousness beyond which a patient could be considered to be anaesthetised (AAP 1992):

"a state of depression of the central nervous system which reduces anxiety thus enabling treatment to be carried out satisfactorily. During sedation the patient will be able to independently maintain an open mouth, and respond sensibly to verbal commands. In addition, the patient will retain adequate function of protective reflexes such as the laryngeal reflex. The drugs used should carry a margin of safety sufficient to render unintended loss of consciousness extremely unlikely."

This type of sedation will be referred to as conscious sedation or moderate sedation.

This review will not consider agents used to induce so-called 'deep sedation' for the above mentioned reasons. Deep sedation can be defined as (AAP 1992):

"a medically controlled state of depression consciousness or unconsciousness from which the patient is not easily aroused. Deep sedation may be accompanied by a partial or complete loss of protective reflexes, including the inability to maintain an airway independently and to respond purposefully to physical stimulation or to verbal command. The state and risks of deep sedation may be indistinguishable from those of general anaesthesia."

\section{Why it is important to do this review}

Commonly used agents for sedation include the benzodiazepines, nitrous oxide or other agents. Unfortunately these agents are delivered by a large variety of methods (such as oral, rectal and nasal), in a bewildering variety of combinations and in varying doses. They may also be used in conjunction with forms of physical restraint (such as a papoose board). A preliminary search of the literature suggests that very few of these drugs have been assessed against a negative or placebo control to test their efficacy. In addition many of the agents or combinations of agents may induce deep sedation rather than conscious sedation. Finally, outcome variables in the majority of studies assessing the different sedative agents appear to focus predominantly on its effect on behaviour rather than anxiety.

The aim of this review was to determine which sedative agents are effective for behaviour management in children who are receiving dental care in order to allow completion of dental treatment. This is the second update of the Cochrane Review first published in 2005 and previously updated in 2012 (Matharu 2005; Matharu 2012).

\section{O B JECTIVES}

To evaluate the efficacy and relative efficacy of conscious sedation agents and dosages for behaviour management in paediatric dentistry.

\section{METHO DS}

\section{Criteria for considering studies for this review}

\section{Types of studies}

Randomised controlled trials (including cluster-randomised). Quasi-randomised trials were excluded. We also excluded crossover trials from this review, as they are not an appropriate study design when the intervention can have a long lasting effect (Higgins 2011). The relationship between pain and anxiety is well established, it is clear that the child's experience of any procedure will have an impact on any subsequent one (Shashikiran 2006).

\section{Types of participants}

Both the following criteria had to be met for a study to be included in this review. 
- Children and adolescents aged 0 to 16 years of age (including children with specific medical or behavioural problems).

- Children having simple restorative treatment with local anaesthesia (e.g. fillings, stainless steel crowns), simple extractions or management of dental trauma (e.g. repositioning of tooth, splinting, removal of nerve from tooth).

Studies where children were having complex surgical procedures were not included in this review. We included studies regardless of whether a measure of anxiety was reported at baseline.

\section{Types of interventions}

\section{Test group}

Any sedative agent via any route of admission that can be administered by a dentist, anaesthetist, sedationist or dental auxiliary in an outpatient setting or dental office. Studies that reported induction of deep sedation were excluded.

\section{Control group}

Placebo (including no intervention) or alternative sedation agent or different dosage of the same agent.

\section{Types of outcome measures}

\section{Primary outcomes}

- Behaviour.

This was measured by a range of different indices; where possible these were combined to allow meta-analysis to be carried out Behaviour for the procedure overall would be recorded; if this information was not available then behaviour at the time of injection was used.

\section{Secondary outcomes}

- Completion of treatment (yes/no).

- Postoperative anxiety.

- Adverse events.

\section{Search methods for identification of studies}

\section{Electronic searches}

Cochrane Oral Health's Information Specialist conducted systematic searches in the following databases for randomised controlled trials and controlled clinical trials without language or publication status restrictions:

- Cochrane Oral Health's Trials Register (searched 22 February 2018) (Appendix 1);

- Cochrane Central Register of Controlled Trials (CENTRAL; 2018, Issue 1) in the Cochrane Library (searched 22 February 2018) (Appendix 2);

- MEDLINE Ovid (1946 to 22 February 2018) (Appendix 3);

- Embase Ovid (1980 to 22 February 2018) (Appendix 4).

Subject strategies were modelled on the search strategy designed for MEDLINE Ovid. Where appropriate, they were combined with subject strategy adaptations of the highly sensitive search strategy designed by Cochrane for identifying randomised controlled trials and controlled clinical trials as described in the Cochrane Handbook for Systematic Reviews of Interventions Chapter 6 (Lefebvre 2011).

\section{Searching other resources}

The following trial registries were searched for ongoing studies:

- US National Institutes of Health Ongoing Trials Register ClinicalTrials.gov (clinicaltrials.gov; searched 22 February 2018) (Appendix 5);

- World Health Organization International Clinical Trials Registry Platform (apps.who.int/trialsearch; searched 22 February 2018) (Appendix 6).

The reference lists of all eligible trials were checked for additional studies.

Specialists in the field known to review authors were contacted for any unpublished data.

Titles and abstracts were assessed by review authors for inclusion in the review.

We did not perform a separate search for adverse effects of interventions used, we considered adverse effects described in included studies only.

\section{Data collection and analysis}

\section{Selection of studies}

Following the electronic search, two review authors independently screened the titles and abstracts to exclude all articles clearly not meeting the inclusion criteria. The search was designed to be sensitive and include controlled clinical trials, these were filtered out early in the selection process if they were not randomised. Of all the remaining articles, full texts were obtained and assessed independently by two review authors and only articles fully meeting the inclusion criteria were considered. Any disagreements were resolved by discussion.

\section{Data extraction and management}

Data extraction was carried out on a specially designed form independently by two review authors who were blinded to each other's data. Results were compared to check for inconsistencies and disagreements resolved by discussion. Review authors were not blinded to the journal of publication or the author's names on the papers.

Descriptive data collected (where available) in addition to that already outlined included:

- year study started, if not available, year it was published,

- country where study was carried out,

- use of supplemental nitrous oxide gas $\left(\mathrm{N}_{2} \mathrm{O}\right)$,

- use of restraints during the procedure,

- previous dental treatments of patients,

- anxiety prior to treatment,

- baseline behaviour,

- sample size calculation,

- dental treatment procedure,

- fasting before the procedure,

- level of consciousness throughout the procedure,

- adverse effects,

- monitoring used, 
- procedure and recovery time,

- assessment of examiner variability,

- patient satisfaction/acceptance.

The characteristics of the trial participants, interventions and outcomes for the included trials are presented in Characteristics of included studies table. Where information in the published report was incomplete or unclear, we contacted the trial authors for clarification or for further information.

\section{Assessment of risk of bias in included studies}

We assessed risk of bias in included studies using Cochrane's risk of bias tool and the methodology set out in the Cochrane Handbook for Systematic Reviews of Interventions (Higgins 2011). We analysed data using Review Manager software (Review Manager 2014). We completed a 'Risk of bias' table for each included study. Each study was assessed on the following domains:

- sequence generation (selection bias),

- allocation concealment (selection bias),

- blinding - of participant and operator/sedationist (performance bias), and outcome assessor (detection bias). If the authors stated that a study was double-blinded then it was assumed that at least the patient and outcome assessor were blinded,

- incomplete outcome data (attrition bias),

- free of selective outcome reporting (reporting bias),

- free of other bias.

For each domain the risk of bias was judged either low, unclear or high.

We categorised the overall risk of bias of individual studies. Studies were categorised as being at low, high, or unclear risk of bias according to the following criteria:

- low risk of bias (plausible bias unlikely to seriously alter the results) if all domains were at low risk of bias;

- high risk of bias (plausible bias that seriously weakens confidence in the results) if one or more domains were at high risk of bias; or

- unclear risk of bias (plausible bias that raises some doubt about the results) if one or more domains were at unclear risk of bias.

We also presented the 'Risk of bias' summary graphically.

\section{Measures of treatment effect}

Dichotomous outcomes such as treatment completion were compared by calculating risk ratios along with $95 \%$ confidence intervals. Continuous outcomes (e.g. Frankl behaviour scale) were reported as mean and standard deviations in each group.

In this review outcome measures were reported either using scales where a higher score is associated with desired behaviour, or scales where a higher score indicates greater anxiety (i.e. undesirable outcome). In order for outcomes to be comparable between studies, anxiety scores (as measured on the Venham scale) were transformed by subtracting the mean score per group from the maximum possible score of five (see Cochrane Handbook for Systematic Reviews of Interventions Section 9.2.3.2 (Higgins 2011)).

\section{Unit of analysis issues}

The participant was the unit of analysis. Cross-over trials were excluded because the level of baseline anxiety/behaviour in the second treatment phase is highly dependent on the success or otherwise of the first treatment period.

\section{Dealing with missing data}

Only available data were analysed. We attempted to contact the author(s) of all included studies, where feasible, for clarification, and missing data.

\section{Assessment of heterogeneity}

Heterogeneity in the results of the trials was assessed where appropriate by inspection of a graphical display of the results and by formal tests of heterogeneity (Higgins 2011).

\section{Assessment of reporting biases}

If sufficient number of studies were included in a meta-analysis, we would have assessed publication bias according to the recommendations on testing for funnel plot asymmetry (Egger 1997), as described in Section 10.4 of the Cochrane Handbook for Systematic Reviews of Interventions (Higgins 2011). If asymmetry were identified, we would have examined possible causes.

\section{Data synthesis}

Where either dichotomous outcome variables or continuous outcome variables with means and standard deviations were available, these data were recorded.

- Completion of treatment (yes/no).

- Difference in behaviour between test and control groups.

- Difference in postoperative anxiety between test and control groups.

- Adverse events.

Because the trials included in this review presented complex data with a range of different interventions being compared and different outcome measures, we separated studies into three groups:

- those comparing active treatment with a placebo;

- those comparing different doses of the same agent (or different routes of administration of the same agent);

- those which compare different agents head to head.

Results of individual studies are presented in a narrative format and differences between interventions are reported as statistically significant if the trial reported $P<0.05$. Data from these three groups were summarised in Additional Table 1; Table 2; and Table 3 respectively. There were few opportunities to combine data from similar trials for meta-analysis, but where this was possible the data are presented in forest plots in Analyses 1 to 5 in the Data and analyses section. Data from trials evaluating active interventions compared to placebo, or the following four commonly used agents: chloral hydrate, ketamine, midazolam or nitrous oxide were presented. It was not possible nor did we attempt to combine these data by meta-analysis. However, we decided that presenting data within forest plots would help the reader to understand the data. The following rules were used when compiling this information. 
- Where data were only presented in their raw format this was used to calculate the appropriate mean and standard deviations.

- Data were treated as continuous even though Houpt (and other scales) were commonly used as outcome measure (ranked scores).

- Houpt was taken as the standard when ranking behaviour i.e. higher values equal better behaviour. Where scales ran in the reverse order, values were transformed so that higher values equalled better behaviour e.g. anxiety scores as measured on the Venham scale have been transformed by subtracting the mean score per group from the maximum possible score (see Higgins 2011 Section 9.2.3.2).

- Where dosage studies were analysed, the lowest dosage was compared to the highest dosage. Results from the lowest dosage were listed first.

'Summary of findings' tables were produced for data from placebo studies only as in the other groups the large number of different combinations tested made this type of summary difficult to understand.

\section{Subgroup analysis and investigation of heterogeneity}

We proposed conducting subgroup analyses for the following groups provided sufficient data existed.

- Age.

This would be subdivided into three groups, 0 to 5,6 to 11,12 to 17 (as recommended by the British National Formulary (BNF) when prescribing drugs to children).

- Dental procedure.

\section{Sensitivity analysis}

Sensitivity analysis was planned a priori to compare the study results for risk of bias. Both fixed and random-effects model metaanalyses were undertaken to assess the robustness of the results.

\section{Summary of findings}

The certainty of the evidence was assessed using GRADE methodology. We produced 'Summary of findings' tables for the main comparisons of the review and the following outcomes: mean Houpt/other behavioral score and good or better behaviour, and adverse events. We used GRADE methods (GRADE 2004), and the GRADEpro online tool for developing the 'Summary of findings' tables (www.guidelinedevelopment.org). We assessed the certainty of the body of evidence for each comparison and outcome by considering the overall risk of bias of the included studies, the directness of the evidence, the inconsistency of the results, the precision of the estimates, and the risk of publication bias. We categorised the certainty of each body of evidence as high, moderate, low, or very low.

\section{RES U L T S}

\section{Description of studies}

\section{Results of the search}

As this is the first version of this review to incorporate a PRISMA flow diagram (Figure 1), only information about searches for the current update are presented, the previous version of the review serves as one particular source of studies. One thousand one hundred and fifty-six records were identified in this update as possibly meeting the inclusion criteria. We screened the title and abstracts of 180 records and assessed 16 full-text articles for eligibility. Of these, two studies were excluded, with reasons, bringing the total number of excluded studies (including the 114 from the previous version of this review) to 116 . Fourteen studies were found to fulfil the inclusion criteria of the review bringing the total number of included studies (including the 36 from the previous version of this review) to 50. Summary details are given in the Characteristics of included studies and Characteristics of excluded studies tables. 
Figure 1. Study flow diagram.

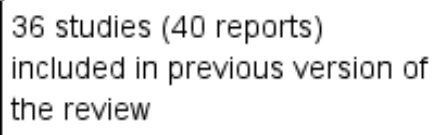

36 studies (40 reports) included in previous version of the review

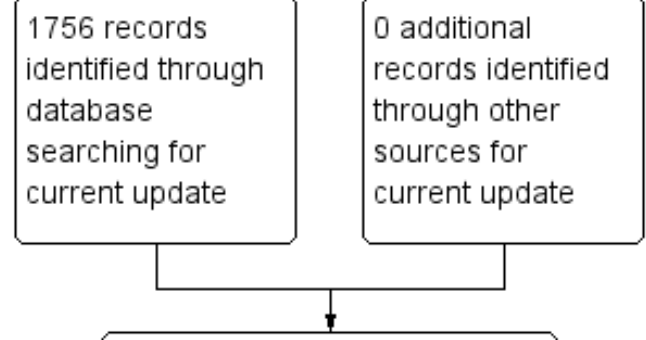

1156 records after duplicates removed for current update

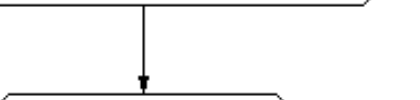

$$
\begin{aligned}
& 180 \text { records } \\
& \text { screened for }
\end{aligned}
$$$$
\text { current update }
$$
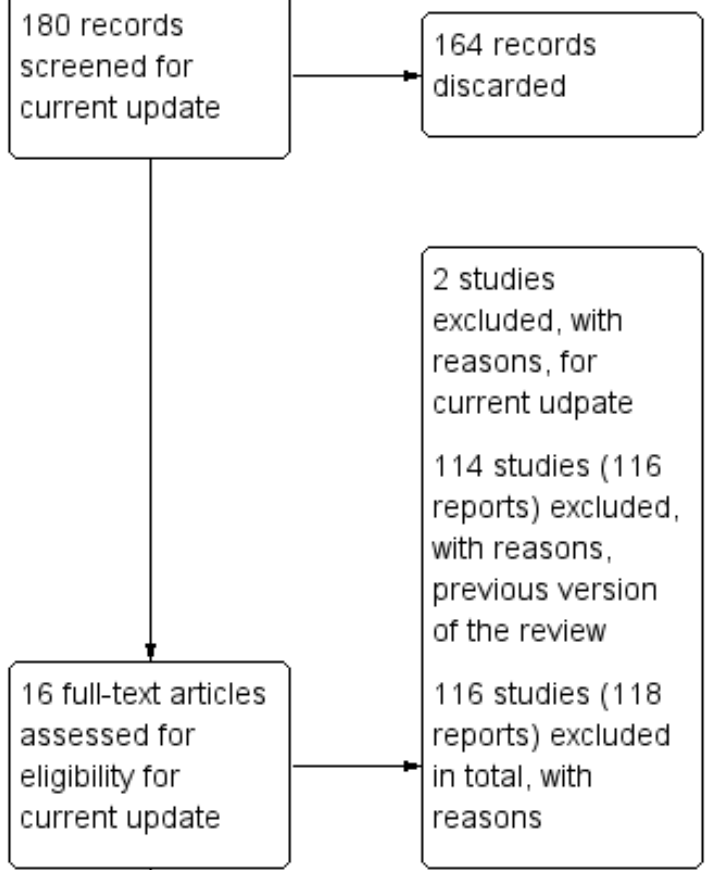

14 studies included in current udpate

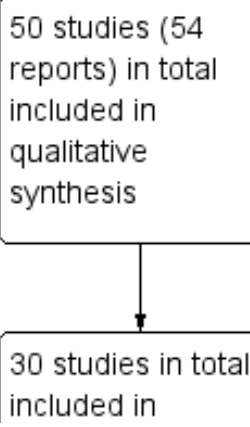


Figure 1. (Continued)

30 studies in total
included in
quantitative
synthesis
(meta-analysis)

\section{Included studies}

\section{Characteristics of the studies}

Dates of publication ranged from 1966 to 2017.

Studies were undertaken in 16 different countries with the greatest proportion of studies ( $n=12,24 \%$ ) from the USA (see Characteristics of included studies table for details).

Six studies reported a sample size calculation (Baygin 2010; Gomes 2017; Isik 2008a; Moreira 2013; Shanmugaavel 2016a; Shanmugaavel 2016b). Averley et al conducted a pilot study (Averley 2004a) which refers to the collection of information to enable a sample size calculation to be done, and this pilot was then followed by a full trial (Averley 2004b). However, a sample size calculation was not reported in the published papers for either of these studies.

\section{Characteristics of the participants}

Age of participants included in the trials ranged from 1 year to 16 years. Mean age (approximation) for all studies was 4.8 years. The mean number of participants was 74.08 (standard deviation (SD) $=109$ ) with a total of 3704 subjects randomised in the 50 included trials.

In the majority of studies ( $\mathrm{n}=39,78 \%$ ) subjects were reported as being unco-operative or anxious at the beginning of the study with the Frankl behavioural rating scale often used to measure baseline behaviour. Sixteen of the included studies reported the use of restrain such as papoose boards or pediwrap to support or restrain children during the dental procedure. Papoose boards were used in seven of the studies conducted in the USA (Alfonzo-Echeverri 1993; Bui 2002; Lam 2005; Lee-Kim 2004; Meyer 1990; Reeves 1996; Sams 1993a), and also in Brazil (Moreira 2013), China (Wan 2006), Mexico (Avalos-Arenas 1998) and Saudi Arabia (Al-Rakaf 2001), and the trials by Faytrouny 2007 and Özen 2012 used a pediwrap.

\section{Characteristics of interventions}

A wide variety of drugs $(n=34)$ either singly or in combination were used (Additional Table 4) and delivered orally, intranasally, intravenously, rectally, intramuscularly, submucosally, transmucosally or by inhalation depending on the type of drug and experimental aims. Inhalation sedation required a bulky machine and scavenging system. Intranasal sedation was administered by a metered-dose atomizer. Rectal sedation was usually given with a rectal applicator applied to a syringe inserted 3 to 4 centimetres into the rectum and the buttocks opposed tightly for 1 minute. In some studies, enemas were given to parents to apply 1 hour before each appointment to avoid variations in rectal absorption.

In 14 of the studies (28\%) all participants were administered supplemental nitrous oxide/oxygen (Alfonzo-Echeverri 1993;
Baygin 2010; Bui 2002; Faytrouny 2007; Isik 2008a; Isik 2008b; Lam 2005; Lee-Kim 2004; Meyer 1990; Moody 1986; Moore 1984; Özen 2012; Park 2006; Sams 1993a). The proportion of studies looking at either comparison with a placebo, comparison of the same drug with different dosages, or comparison of different drugs are summarised in Additional Table 1, Table 2, and Table 3. Some of the studies appear in more than one group as they included a combination of these types.

Dental treatment was poorly described on the whole, all subjects appeared to have some sort of restoration under rubber dam or extraction with local anaesthetic, but little information was given on type of restoration, number of teeth involved, type of local anaesthetic or if any attempt was made to ensure similar treatment was provided in control and experimental groups.

In the following section summary data are presented first, followed by a more detailed breakdown into three classifications. This is intended to help the reader in meaningful interpretation of the data. The three classifications are as follows.

1. Studies where test drug(s) were compared to a placebo.

2. Studies where differing dosages of the same $\operatorname{drug}(\mathrm{s})$ were compared.

3. Studies comparing different drugs, or combinations of drugs.

Within each of the three classifications, studies have been grouped where possible by the chief agent used (e.g. chloral hydrate, nitrous oxide, etc.). This was difficult when collating data for studies comparing different drugs or combinations of drugs, therefore some of the grouping decisions made for this table may appear arbitrary. Nevertheless we feel that this grouping helps the reader to understand these data. Drug groupings are in alphabetical order. Where a study compares different drugs with each other and also with a placebo, it has been filed in the placebo section under a different heading for each drug. It has also been filed in the drug comparison section. Where different routes of administration of the same drug have been compared, this has been filed in the dosage section.

\section{Characteristics of outcome measures}

Of the outcome measures proposed for this review (completion of treatment, difference in behaviour, difference in postoperative anxiety, and adverse events), meaningful data could only be extracted on behaviour. Postoperative anxiety was rarely mentioned and in most of the studies almost all the participants completed treatment. Adverse events were recorded but this was not done in a uniform manner between studies.

Outcome variables reported in the studies were predominantly ordinal (e.g. five-point scale for increasing movement) or dichotomous in nature (e.g. success/failure). Methods used for statistical analysis in the trials included both non-parametric (Chi2 
test, Wilcoxon matched pairs, Kruskal-Wallis, Mann-Whitney $U$ test, Fishers Exact test, non-parametric two-factor ANOVA, McNemar test, sign test) and parametric tests (t-test, ANOVA, Tukey's range test, Friedman two-way analysis, method of least squares).

Measures of behaviour or level of sedation scales were commonly used (Houpt or modified versions of Houpt used most frequently ( $n=19,40 \%$ ). Nineteen different types of measurement scales for behaviour or sedation were used and these are summarised in Additional Table 5 and Table 6.

\section{Placebo-controlled studies}

There were 12 placebo studies included which investigated oral chloral hydrate (Moore 1984), intranasal dexmedetomidine (Malhotra 2016), oral diazepam (Tyagi 2012), melatonin (Isik 2008a), intramuscular meperidine (McKee 1990), oral midazolam (Gallardo 1994; Isik 2008a; Kapur 2004; Moreira 2013; Mortazavi 2009; Tyagi 2012; Wan 2006), intravenous midazolam (Tyagi 2012), midazolam/ ketamine (Malhotra 2016; Moreira 2013), and nitrous oxide (Nathan 1988; Veerkamp 1993) (Additional Table 1).

Where the general medical status of the children was reported they were usually healthy or had mild systemic disease (American Society of Anesthesiologists (ASA) physical status classification system: ASA I and ASA II). Six papers did not report on the gender balance, seven did not report the weight of the children.

Times for withholding food prior to the sedation (NPO - nil per os: nothing by mouth) were given in four papers (Isik 2008a; Kapur 2004; Mortazavi 2009; Wan 2006). Monitoring of the children during the sedation included blood pressure, heart rate, oxygen saturation, body temperature, and respiratory rate. There was no specified involvement with an anaesthetist during sedation though in some studies patients were assessed by an anaesthetist before treatment.

Papoose board or pediwrap was used in one study (Wan 2006). Nitrous oxide was used in conjunction with the main sedative agents under test in two studies (Isik 2008a; Moore 1984). A range of outcome variables were used and these are summarised in Additional Table 1. One study reported recovery times (Nathan 1988) and three gave the total treatment time (Isik 2008a; Kapur 2004; Veerkamp 1993). Three studies used video cameras to record sedation during dental treatment (Nathan 1988; Veerkamp 1993; Wan 2006).

Data from the different drug types are listed below.

\section{Oral midazolam}

Seven trials compared oral midazolam with placebo (Gallardo 1994; Isik 2008a; Kapur 2004; Moreira 2013 Mortazavi 2009; Tyagi 2012; Wan 2006).

Gallardo 1994 randomised children aged 4 to 10 years to either 7.5 $\mathrm{mg}$ of midazolam or placebo (the range of weight of the children included in the trial is not reported but the stated average weight of $21.65 \mathrm{~kg}$ would result in a dose equivalent to $0.35 \mathrm{mg} / \mathrm{kg}$ ). The actual dose in $\mathrm{mg} / \mathrm{kg}$ would be expected to vary considerably. The authors used means and standard errors to summarise ranked data in each group with only three categories which was thought to be inappropriate. However, subsequent analysis using Wilcoxon's rank test was appropriate. Midazolam was reported to be significantly better than placebo.

Isik 2008a used a dose of $0.75 \mathrm{mg} / \mathrm{kg}$ and noted vomiting and hiccupping in the midazolam group.

Kapur 2004 described midazolam delivery in their study as being a mixture of oral and transmucosal with a dose of $0.5 \mathrm{mg} / \mathrm{kg}$.

Moreira 2013 used the highest dose in this group of trials, of $1 \mathrm{mg} / \mathrm{kg}$. Co-operation as recorded by the sum of the Ohio State University Behavior Rating Scale (OSUBRS) score at each measurement point was not significantly different than the placebo $(\mathrm{P}=0.55)$.

Mortazavi 2009 used the lowest dose of the five trials in this group $(0.25 \mathrm{mg} / \mathrm{kg})$.

Tyagi 2012 used a dose of $0.5 \mathrm{mg} / \mathrm{kg}$.

Wan 2006 used a dose of $0.5 \mathrm{mg} / \mathrm{kg}$ and noted amnesia associated with midazolam use.

\section{Nitrous oxide/oxygen}

Two studies (Nathan 1988; Veerkamp 1993) evaluated nitrous oxide/oxygen sedation compared to placebo and both were assessed as being at high risk of bias. In Nathan 1988 children received 20\% to 50\% nitrous oxide in oxygen and in Veerkamp 1993 participants received up to $40 \%$ nitrous oxide in oxygen. No adverse effects were mentioned.

\section{Chloral hydrate}

In Moore 1984 children were randomly allocated to either $20 \mathrm{mg} /$ $\mathrm{kg}, 40 \mathrm{mg} / \mathrm{kg}$ or $60 \mathrm{mg} / \mathrm{kg}$ of chloral hydrate or a placebo and then all children received up to $40 \%$ nitrous oxide in oxygen as well. This trial was assessed as being at high risk of bias.

\section{Meperidine}

Intramuscular meperidine $(0.55 \mathrm{mg} / \mathrm{kg}$ to $2.2 \mathrm{mg} / \mathrm{kg}$ - calculated from $\mathrm{mg} / \mathrm{lb}$ given in text) was evaluated in a single study (McKee 1990) which was assessed at unclear risk of bias.

\section{Intravenous midazolam}

$0.06 \mathrm{mg} / \mathrm{kg}$ body weight was used in one study, Tyagi 2012, assessed as at high risk of bias.

\section{Oral diazepam}

$0.5 \mathrm{mg} / \mathrm{kg}$ body weight was used in one study, Tyagi 2012, assessed as at high risk of bias.

\section{Midazolam/ketamine}

Moreira 2013 used a dose of $0.5 \mathrm{mg} / \mathrm{kg}$ midazolam with $3 \mathrm{mg} / \mathrm{kg}$ ketamine.

\section{Dose comparison studies}

There were 10 studies which compared different dosages or routes of admission of sedative agents: one used hydroxyzine (Faytrouny 2007), the remaining nine varied dosage or method of midazolam with six primarily using intranasal midazolam (Al-Rakaf 2001; Lam 2005; Lee-Kim 2004; Shashikiran 2006; Shanmugaavel 2016a; 
Shanmugaavel 2016b) and three oral midazolam (Aydintug 2004; Isik 2008b; Somri 2012) (Additional Table 2).

All children were assessed as healthy or having mild systemic disease (ASA I and ASA II). Eight studies described the gender balance. Seven recorded the mean weight. Two studies measured baseline anxiety and compared this to anxiety at the end (Shanmugaavel 2016a; Shanmugaavel 2016b).

All studies described NPO times which ranged from either a light breakfast (but no milk) up to nothing from midnight. Monitoring was reported in all studies, using a precordial stethoscope, blood pressure unit and electrocardiograph as well as clinical observations. Five studies mentioned the involvement of anaesthetists (Al-Rakaf 2001; Lam 2005; Shanmugaavel 2016a; Shanmugaavel 2016b; Somri 2012).

Use of papoose board (or equivalent) was mentioned in four studies (Al-Rakaf 2001; Lam 2005; Lee-Kim 2004; Shanmugaavel 2016a), one study mentioned manual restraint (Somri 2012). In four studies nitrous oxide was used in conjunction with the main sedative agent (Faytrouny 2007; Isik 2008b; Lam 2005; Lee-Kim 2004). A range of outcome variables were used and these are summarised in Additional Table 2. Three studies recorded recovery times (Al-Rakaf 2001; Isik 2008b; Shashikiran 2006) and two gave the total dental treatment time (Shashikiran 2006; Somri 2012). Four studies used video cameras to record dental treatment during sedation (Lam 2005; Lee-Kim 2004; Shanmugaavel 2016a; Shanmugaavel 2016b).

In addition to looking at behaviour ratings and sedation, Al-Rakaf 2001 also assessed the effects of fasting on behaviour.

Data from the different drug types are listed below.

\section{Hydroxyzine}

One study (Faytrouny 2007) looked at the effect of a dose of hydroxyzine given 24 hours preoperatively $(20 \mathrm{mg})$ at home followed by a second dose at the appointment $(3.7 \mathrm{mg} / \mathrm{kg}$ ) versus hydroxyzine given at the appointment only $(3.7 \mathrm{mg} / \mathrm{kg})$. The study was at high risk of bias. All children also received $50 \%$ nitrous oxide. Faytrouny 2007 reported the dose as $20 \mathrm{mg} / \mathrm{kg}$ hydroxyzine in the main text but $20 \mathrm{mg}$ in the abstract.

\section{Midazolam (intranasal)}

Six studies looked primarily at intranasal midazolam (AlRakaf 2001; Lam 2005; Lee-Kim 2004; Shanmugaavel 2016a; Shanmugaavel 2016b; Shashikiran 2006). The participants in the Lam 2005 and Lee-Kim 2004 trials all received nitrous oxide inhalation as well at $50 \%$ or $45 \%$ respectively. All studies were at high risk of bias.

Al-Rakaf 2001 compared $0.5 \mathrm{mg}$ intranasal midazolam to either 0.3 $\mathrm{mg} / \mathrm{kg}$ or $0.4 \mathrm{mg} / \mathrm{kg}$.

Lee-Kim 2004 compared intranasal midazolam $(0.3 \mathrm{mg} / \mathrm{kg})$ to oral midazolam $(0.7 \mathrm{mg} / \mathrm{kg})$.

Lam 2005 and Shashikiran 2006 compared $0.2 \mathrm{mg} / \mathrm{kg}$ intranasal midazolam versus $0.2 \mathrm{mg} / \mathrm{kg}$ intramuscular midazolam. Lam 2005 used the midazolam as a premedication for an unspecified intravenous sedative.
Shanmugaavel 2016a and Shanmugaavel 2016b compared $0.2 \mathrm{mg} /$ $\mathrm{kg}$ intranasal midazolam to $0.2 \mathrm{mg} / \mathrm{kg}$ sublingual midazolam.

\section{Midazolam (oral)}

Three studies (Aydintug 2004; Isik 2008b; Somri 2012) evaluated oral midazolam, with participants in Isik 2008b also receiving nitrous oxide inhalation. Aydintug 2004 was assessed as being at high risk of bias and in Isik 2008b; Somri 2012 risk of bias was unclear.

Aydintug 2004 compared $0.5 \mathrm{mg} / \mathrm{kg}$ oral midazolam versus 0.35 $\mathrm{mg} / \mathrm{kg}$ rectal midazolam.

Isik 2008b randomised children to oral doses of either $0.2 \mathrm{mg} / \mathrm{kg}$, $0.5 \mathrm{mg} / \mathrm{kg}, 0.75 \mathrm{mg} / \mathrm{kg}$ or $1 \mathrm{mg} / \mathrm{kg}$ after fasting for 3 to 5 hours. All children also received $40 \%$ nitrous oxide in oxygen (Additional Table 2).

Somri 2012 compared oral doses of $0.5 \mathrm{mg} / \mathrm{kg}, 0.75 \mathrm{mg} / \mathrm{kg}$ and 1 $\mathrm{mg} / \mathrm{kg}$

\section{Head-to-head drug comparison studies}

There were 31 studies comparing different drugs and delivery methods which are summarised in Additional Table 3.

All studies reported children's medical status at baseline. In 14 studies gender was not specified and in 22 papers the mean weight of participants was not described. The age of children in these studies ranged from 1 year to 14 years of age.

NPO was not mentioned in 12 of the studies (Abrams 1993; Averley 2004a; Averley 2004b; Bhatnagar 2012; Koirala 2006; Lahoud 2002; Özen 2012; Roelofse 1996a; Roelofse 1996b; Singh 2002; Tyagi 2012; Torres-Perez 2007). Of those studies reporting NPO, times ranged from midnight to 2 hours before sedation or appointment. Monitoring was well reported in most of the studies and included verbal contact, pulse oximeter, precordial stethoscope, automatic blood pressure, capnograph, nasal respiration monitor, endtidal carbon dioxide tension. Fourteen studies mentioned the involvement of anaesthetists (Abrams 1993; Alfonzo-Echeverri 1993; Averley 2004a; Averley 2004b; Bhatnagar 2012; Eshghi 2016; Gomes 2017; Kaviani 2015; Lahoud 2002; Malhotra 2016; Moreira 2013; Singh 2014; Surendar 2014; Tyagi 2012).

The use of a papoose board was mentioned in nine of the studies (Alfonzo-Echeverri 1993; Avalos-Arenas 1998; Bui 2002; Meyer 1990; Moreira 2013; Özen 2012; Park 2006; Reeves 1996; Sams 1993a), and in seven nitrous oxide/oxygen inhalation was used in conjunction with sedation (Alfonzo-Echeverri 1993; Baygin 2010; Bui 2002; Meyer 1990; Moody 1986; Özen 2012; Sams 1993a). A range of outcome variables were used and these are summarised in Additional Table 3. Two papers reported dentist and parents preferences after sedation (Averley 2004a; Averley 2004b). Recovery times were given in 13 papers (Abrams 1993; Alfonzo-Echeverri 1993; Averley 2004a; Averley 2004b; Eshghi 2016; Kaviani 2015; Lahoud 2002; Meyer 1990; Roelofse 1996a; Roelofse 1996b; Singh 2002; Singh 2014; Surendar 2014), and nine gave the total dental treatment time (Alfonzo-Echeverri 1993; Avalos-Arenas 1998; Baygin 2010; Bui 2002; Lahoud 2002; Reeves 1996; Roelofse 1996a; Roelofse 1998; Torres-Perez 2007). Four studies used video cameras to record sedation during dental treatment (Gomes 2017; Meyer 1990; Park 2006; Surendar 2014). 
Data from drug types is summarised below.

\section{Chloral hydrate/hydroxyzine}

Six studies investigated chloral hydrate/hydroxyzine and compared it to other agents (Avalos-Arenas 1998; Meyer 1990; Moody 1986; Park 2006; Reeves 1996; Torres-Perez 2007). In Meyer 1990; Moody 1986 and Park 2006 all participants also received nitrous oxide inhalation. All studies in this group were assessed at high risk of bias.

Avalos-Arenas 1998 compared chloral hydrate $(70 \mathrm{mg} / \mathrm{kg}) /$ hydroxyzine $(2 \mathrm{mg} / \mathrm{kg})$ with chloral hydrate $(70 \mathrm{mg} / \mathrm{kg})$ alone.

Meyer 1990 compared oral chloral hydrate $(40 \mathrm{mg} / \mathrm{kg}$ ) plus hydroxyzine $(25 \mathrm{mg})$ with oral triazolam $(0.02 \mathrm{mg} / \mathrm{kg})$ in children who also received inhalation of $40 \%$ nitrous oxide.

In the trial by Moody 1986 rectal chloral hydrate $(50 \mathrm{mg} / \mathrm{kg}$ ) was compared with either oral chloral hydrate $(50 \mathrm{mg} / \mathrm{kg}$ ) or oral chloral hydrate $(30 \mathrm{mg} / \mathrm{kg})$ plus hydroxyzine $(25 \mathrm{mg})$ in children who all received $30 \%$ to $50 \%$ inhalational nitrous oxide as well.

Park 2006 compared chloral hydrate $(60 \mathrm{mg} / \mathrm{kg}$ ) plus hydroxyzine (1 $\mathrm{mg} / \mathrm{kg}$ ) to chloral hydrate $(60 \mathrm{mg} / \mathrm{kg}$ oral) plus hydroxyzine $(1 \mathrm{mg} /$ $\mathrm{kg}$ oral) plus midazolam $(0.1 \mathrm{mg} / \mathrm{kg}$ submucosal) in children who all received $50 \%$ inhalational nitrous oxide as well. Outcome measures were Houpt and whether or not restraint was required.

Chloral hydrate $(50 \mathrm{mg} / \mathrm{kg}$ ) plus hydroxyzine $(25 \mathrm{mg})$ was compared to oral midazolam $(0.5 \mathrm{mg} / \mathrm{kg})$ plus acetaminophen $(10 \mathrm{mg} / \mathrm{kg})(\mathrm{M} /$ A) in Reeves 1996.

In a trial by Torres-Perez 2007 children were randomised to sedation with chloral hydrate $(50 \mathrm{mg} / \mathrm{kg}) /$ hydroxyzine $(1.5 \mathrm{mg} / \mathrm{kg})$ or midazolam $(0.5 \mathrm{mg} / \mathrm{kg}) /$ hydroxyzine $(1.5 \mathrm{mg} / \mathrm{kg})$ or hydroxyzine ( $2 \mathrm{mg} / \mathrm{kg}$ plus further $1 \mathrm{mg} / \mathrm{kg}$ ).

\section{Chloral hydrate/promethazine}

Sams 1993a compared chloral hydrate $(50 \mathrm{mg} / \mathrm{kg}) /$ promethazine $(1 \mathrm{mg} / \mathrm{kg})$ with meperidine $(1 \mathrm{mg} / \mathrm{kg}) /$ promethazine $(1 \mathrm{mg} / \mathrm{kg})$, in children planned to receive inhalational nitrous oxide as well.

\section{Dexmedetomidine}

Surendar 2014 randomised patients into four groups for intranasal intervention: dexmedetomidine $(1 \mu \mathrm{g} / \mathrm{kg})$, dexmedetomidine $(1.5$ $\mu \mathrm{g} / \mathrm{kg}$ ), midazolam (0.2 mg/kg), and ketamine ( $5 \mathrm{mg} / \mathrm{kg})$.

\section{Ketamine}

Eight studies evaluated ketamine (Abrams 1993; Alfonzo-Echeverri 1993; Bui 2002; Rai 2007; Roelofse 1996a; Roelofse 1996b; Roelofse 1998; Singh 2014). In two of these trials (Alfonzo-Echeverri 1993; Bui 2002) nitrous oxide inhalation was also used at a concentration of $30 \%$ to $50 \%$ or $35 \%$ to $50 \%$ respectively. One of the eight trials in this group (Singh 2014) was assessed at low risk of bias, one (Bui 2002) at unclear risk of bias, and the remainder at high risk of bias.

Abrams 1993 compared $3 \mathrm{mg} / \mathrm{kg}$ ketamine with either $0.4 \mathrm{mg} / \mathrm{kg}$ midazolam or $1.0 \mu \mathrm{g} / \mathrm{kg}$ or $1.5 \mu \mathrm{g} / \mathrm{kg}$ sufentanil all administered intranasally.

Anaesthetists in the trial by Rai 2007 administered a premedication of $0.5 \mathrm{mg} / \mathrm{kg}$ midazolam to all the children followed by a bolus dose plus infusion of either midazolam $(0.1 \mathrm{mg} / \mathrm{kg}$ followed by 0.004 $\mathrm{mg} / \mathrm{kg} / \mathrm{min}$ ), propofol ( $1 \mathrm{mg} / \mathrm{kg}$ followed by $0.06 \mathrm{mg} / \mathrm{kg} / \mathrm{min}$ ) or ketamine $(0.5 \mathrm{mg} / \mathrm{kg}$ followed by $0.01 \mathrm{mg} / \mathrm{kg} / \mathrm{min})$.

Roelofse 1996a compared rectal ketamine $(5 \mathrm{mg} / \mathrm{kg}) / \mathrm{midazolam}$ $(0.35 \mathrm{mg} / \mathrm{kg})$ to rectal midazolam $(1 \mathrm{mg} / \mathrm{kg})$ alone.

In a second study (Roelofse 1996b) children were randomised to either an oral dose of $12.5 \mathrm{mg} / \mathrm{kg}$ ketamine or $0.5 \mathrm{ml} / \mathrm{kg}$ of standard oral premedication (comprising trimeprazine $(6 \mathrm{mg}$ / $\mathrm{ml}) /$ physeptone (methadone) $(0.4 \mathrm{mg} / \mathrm{ml}))$ to which was added droperidol $(0.1 \mathrm{mg} / \mathrm{ml})$.

The third trial by this group (Roelofse 1998) compared oral ketamine $(5 \mathrm{mg} / \mathrm{kg})$ plus midazolam $(0.35 \mathrm{mg} / \mathrm{kg})$ with a combination of oral trimeprazine $(3 \mathrm{mg} / \mathrm{kg})$ and methadone $(0.2$ $\mathrm{mg} / \mathrm{kg}$ ) administered 30 minutes prior to dental treatment.

Two trials evaluated ketamine in combination with inhalation of nitrous oxide (Alfonzo-Echeverri 1993; Bui 2002).

Alfonzo-Echeverri 1993 compared oral ketamine $(6 \mathrm{mg} / \mathrm{kg})$ with oral meperidine $(2 \mathrm{mg} / \mathrm{kg})$ plus promethazine $(0.5 \mathrm{mg} / \mathrm{kg})$ in children who had NPO for 6 hours. Nitrous oxide (30\% to 50\%) was administered to all the children prior to the local anaesthetic.

In the trial by Bui 2002 , oral ketamine $(10 \mathrm{mg} / \mathrm{kg}$ ) was compared with oral ketamine $(10 \mathrm{mg} / \mathrm{kg})$ plus promethazine $(1.1 \mathrm{mg} / \mathrm{kg})$ in a trial where all the participants also received $50 \%$ nitrous oxide inhalation.

Singh 2014 in their trial compared oral ketamine $8 \mathrm{mg} / \mathrm{kg}^{-1}$ to oral dexmedetomidine in doses of $3 \mu \mathrm{g} / \mathrm{kg}^{-1}, 4 \mu \mathrm{g} / \mathrm{kg}^{-1}$ and $5 \mu \mathrm{g} / \mathrm{kg}^{-1}$.

\section{Midazolam (oral)}

Eight studies evaluated oral midazolam compared to other sedatives (Baygin 2010; Bhatnagar 2012; Koirala 2006; Malhotra 2016; Moreira 2013; Özen 2012; Singh 2002; Tyagi 2012). In two of these trials (Baygin 2010; Özen 2012) participants also received nitrous oxide by inhalation. The studies were assessed as being at high risk of bias.

Baygin 2010 randomised participants to either oral administration of hydroxyzine $(1 \mathrm{mg} / \mathrm{kg})$, oral midazolam $(0.7 \mathrm{mg} / \mathrm{kg})$, oral administration of ketamine ( $3 \mathrm{mg} / \mathrm{kg}$ ) plus midazolam $(0.25 \mathrm{mg} / \mathrm{kg})$ or no oral premedication (nitrous oxide alone). All patients in the trial received $40 \%$ nitrous oxide.

Bhatnagar 2012 compared oral administration of midazolam 0.5 $\mathrm{mg} / \mathrm{kg}$, tramadol $2 \mathrm{mg} / \mathrm{kg}$, triclofos $70 \mathrm{mg} / \mathrm{kg}$ and zolpidem $0.4 \mathrm{mg} /$ $\mathrm{kg}$.

Koirala 2006 randomised participants to six different oral interventions: midazolam $(0.5 \mathrm{mg} / \mathrm{kg})$, ketamine $(5 \mathrm{mg} / \mathrm{kg})$, zolpidem $(0.4 \mathrm{mg} / \mathrm{kg})$, midazolam $(0.4 \mathrm{mg} / \mathrm{kg})$ plus ketamine $(3 \mathrm{mg} /$ $\mathrm{kg})$, midazolam $(0.5 \mathrm{mg} / \mathrm{kg})$ plus tramadol $(2 \mathrm{mg} / \mathrm{kg})$ and zolpidem $(0.4 \mathrm{mg} / \mathrm{kg})$ plus tramadol $(2 \mathrm{mg} / \mathrm{kg})$.

Malhotra 2016 compared oral midazolam $(0.5 \mathrm{mg} / \mathrm{kg})$ plus oral ketamine $(5 \mathrm{mg} / \mathrm{kg})$ plus intranasal placebo, with intranasal dexmedetomidine $(1 \mu / \mathrm{kg})$ plus oral placebo and a third group of oral and intranasal placebo.

Moreira 2013 randomised participants into two oral intervention groups: midazolam $(0.5 \mathrm{mg} / \mathrm{kg})$ plus ketamine $(3 \mathrm{mg} / \mathrm{kg})$, 
midazolam $1 \mathrm{mg} / \mathrm{kg}$ and compared it to a no sedation group. The study used protective stabilisation.

Özen 2012 compared four interventions: $0.20 \mathrm{mg} / \mathrm{kg}$ midazolam (40 mg/ml) intranasally plus inhalation sedation 50\%-50\% nitrous oxide/oxygen, $0.75 \mathrm{mg} / \mathrm{kg}$ midazolam $(15 \mathrm{mg} / 3 \mathrm{ml}$ ) orally plus inhalation sedation $50 \%-50 \%$ nitrous oxide/oxygen, $0.50 \mathrm{mg} / \mathrm{kg}$ midazolam (15 mg/3 ml) orally plus inhalation sedation $50 \%-50 \%$ nitrous oxide/oxygen, and inhalation sedation 50\%-50\% nitrous oxide/oxygen. Restraint was used. A modified scale was used to classify behaviour/response to treatment/sedation.

Singh 2002 compared midazolam $(0.5 \mathrm{mg} / \mathrm{kg}$ ) to either triclofos ( 70 $\mathrm{mg} / \mathrm{kg}$ ) or promethazine $(1.3 \mathrm{mg} / \mathrm{kg})$, all administered in fruit juice prior to treatment. Sedation scores were reported on an eight-point scale in which a high score indicated poor sedation.

Tyagi 2012 randomised participants into four groups: oral midazolam $0.5 \mathrm{mg} / \mathrm{kg}$, oral diazepam $0.5 \mathrm{mg} / \mathrm{kg}$, intravenous midazolam $0.06 \mathrm{mg} / \mathrm{kg}$, and placebo.

\section{Midazolam (intravenous)}

Two studies, both at high risk of bias, compared intravenous midazolam to other sedatives (Eshghi 2016; Kaviani 2015).

Eshghi 2016 randomised participants into two groups for intravenous sedation administration: remifentanil $(0.1 \mu \mathrm{g} / \mathrm{kg} / \mathrm{min})$ plus midazolam $(0.01 \mathrm{mg} / \mathrm{kg}$ ) plus propofol $(0.5 \mathrm{mg} / \mathrm{kg})$, and ketamine $(0.5 \mathrm{mg} / \mathrm{kg})$ plus midazolam $(0.1 \mathrm{mg} / \mathrm{kg})$ plus propofol $(0.5 \mathrm{mg} / \mathrm{kg})$.

Kaviani 2015 compared intravenous midazolam $(0.05 \mathrm{mg} / \mathrm{kg})$ plus ketamine $(0.5 \mathrm{mg} / \mathrm{kg})$ with midazolam $(0.05 \mathrm{mg} / \mathrm{kg})$ plus fentanyl $(0.5 \mu \mathrm{g} / \mathrm{kg})$. Additional midazolam $(0.25 \mathrm{mg})$ was administered to both groups if needed.

\section{Midazolam (rectal)}

Rectal sedation was evaluated by Jensen 1999 who compared diazepam $(0.7 \mathrm{mg} / \mathrm{kg})$ with midazolam $(0.3 \mathrm{mg} / \mathrm{kg})$.

\section{Sevoflurane}

Three trials evaluated sevoflurane (Averley 2004a; Averley 2004b; Lahoud 2002), but used different outcome measures. Two were assessed at high and one at unclear (Lahoud 2002) risk of bias.

Lahoud 2002 compared sevoflurane $(0.1 \%$ to $0.3 \%)$ /nitrous oxide (40\%) with nitrous oxide (40\%) alone.

Averley 2004a was a pilot study which randomised children to either intravenous midazolam $(0.5 \mathrm{mg} / \mathrm{min})$ titrated to induce adequate sedation, or $40 \%$ nitrous oxide inhalation plus intravenous midazolam $(0.5 \mathrm{mg} / \mathrm{min})$ titrated to induce adequate sedation, or inhalation of $0.3 \%$ sevoflurane plus $40 \%$ nitrous oxide plus intravenous midazolam $(0.5 \mathrm{mg} / \mathrm{min})$ titrated to induce adequate sedation.

In the subsequent trial (Averley 2004b) the same interventions were used.

\section{Excluded studies}

Reasons for trial exclusion are summarised in Characteristics of excluded studies table. Reasons included description of the study as using deep sedation, the sedative agent being used as a premedication prior to an anaesthetic, no comparative groups or evaluating outcomes not relevant to this review. We continued to exclude cross-over trials.

\section{Risk of bias in included studies}

\section{Allocation}

Eleven studies were assessed as low risk of bias with regard to method of sequence generation (Averley 2004a; Averley 2004b; Eshghi 2016; Gomes 2017; Malhotra 2016; Moreira 2013; Shanmugaavel 2016a; Shanmugaavel 2016b; Singh 2014; Somri 2012; Surendar 2014). Barring four of these (Shanmugaavel 2016a; Shanmugaavel 2016b; Somri 2012; Surendar 2014) all of the others reported adequate allocation concealment. Two other studies were reported as having adequate allocation concealment, but the method of sequence generation in these studies was not described (Jensen 1999; Lahoud 2002). Bui 2002 used an independent person to select patients, make the random allocation and administer the intervention, this was assessed as unclear risk. Eshghi 2016 used an anaesthetist to divide the sample into two groups based on odd and even codes, this was considered to be at unclear risk of bias for allocation concealment. Lee-Kim 2004, the principal investigator conducted the subject selection and random allocation, this was assessed to be at high risk of selection bias. In the remaining trials neither the method of sequence generation, nor any concealment of allocation was described, and these studies were assessed as being at unclear risk of selection bias.

\section{Blinding}

For avoiding performance and detection bias the ideal situation is when the operator, outcome assessor and patient are all blinded to the intervention. However, we acknowledge that in trials of sedative agents in children, blinding of dental operators is difficult in part due to the nature of the equipment and drugs involved, and the need to ensure patient safety during the procedure. Blinding of children participating in these studies is usually possible, especially with young children. Some of the trials incorporated video recordings and one of more outcome assessors, blinded to the allocated treatment, evaluated the outcomes from these recordings.

In many trials the outcome was assessed by the operative dentist carrying out the procedure. In some trials the sedatives were administered by a nurse or researcher and the operator, who was blinded to the intervention, undertook the assessment. In other trials the procedures were videotaped and outcomes were assessed from the recordings, but bias is possible if an unblinded operator interacts with the patients in different ways depending on expectations about the effect of a specific sedative.

Where studies were described as double-blinded, this was interpreted to mean participant and outcome assessor were blinded to the allocated treatment. Where the participant and outcome assessor at least were blinded to the treatment, the risk of performance and detection biases were deemed to be low. The outcome assessor and operator could be separate individuals or the same person.

Twenty-three studies were assessed as being at low risk of performance and detection biases (Alfonzo-Echeverri 1993; AlRakaf 2001; Avalos-Arenas 1998; Averley 2004a; Averley 2004b; 
Bui 2002; Gallardo 1994; Gomes 2017; Isik 2008a; Jensen 1999; Kapur 2004; Koirala 2006; McKee 1990; Moore 1984; Mortazavi 2009; Reeves 1996; Roelofse 1996a; Roelofse 1996b; Sams 1993; Singh 2002; Singh 2014; Surendar 2014; Wan 2006).

In eight trials only the assessor was blinded to the intervention (Lam 2005; Lee-Kim 2004; Meyer 1990; Nathan 1988; Park 2006; Shanmugaavel 2016b; Torres-Perez 2007; Veerkamp 1993).

In five trials the operator and the outcome assessor was blinded (Baygin 2010; Kaviani 2015; Malhotra 2016; Roelofse 1998; Shashikiran 2006).

In three studies only the operator was blinded (Faytrouny 2007; Shanmugaavel 2016a; Somri 2012).

In four trials there was no blinding (Aydintug 2004; Moody 1986; Moreira 2013; Tyagi 2012). The mother of the patient was aware of the treatment in Moreira 2013. In Tyagi 2012 the intravenous midazolam group was not blinded.

There was no placebo used in Baygin 2010, therefore participants would have been aware that this was the control group.

\section{Incomplete outcome data}

The number of trial participants included in the outcome evaluations was poorly reported in many trials, and it was sometimes difficult to determine whether or not dropouts had occurred. Twenty-one studies were at low risk of attrition bias. In three studies the risk of attrition bias was assessed as unclear (Bhatnagar 2012; Malhotra 2016; Nathan 1988) and in the remainder, where incomplete treatment/sedation failure was not recorded or reported on at all, trials were assessed as being at high risk of attrition bias.

\section{Selective reporting}

All but four of the included trials reported the outcomes described in the methods sections of the reports, and were deemed to be at low risk of reporting bias. Averley 2004a and Averley 2004b reported the primary outcome, treatment completion, on all the trial participants who received the allocated intervention, but reported secondary outcomes only on those who were deemed to have undergone successful sedation (69\% and $78 \%$ respectively) of those who received sedation, and $69 \%$ and $65 \%$ of those randomised. Bhatnagar 2012 did not report on the recovery times in the results.

\section{Other potential sources of bias}

There were no baseline demographic data reported on the participants in nine trials (Alfonzo-Echeverri 1993; Al-Rakaf 2001; Bhatnagar 2012; Kaviani 2015; Koirala 2006; Lam 2005; Nathan 1988; Shanmugaavel 2016a; Tyagi 2012), and little or unclear baseline demographic data in a further seven trials (Averley 2004a; Malhotra 2016; Mortazavi 2009; Özen 2012; Rai 2007; Singh 2002; Veerkamp 1993). There were inconsistencies in two trials (Eshghi 2016; Gomes 2017). In the trial by Averley 2004b baseline demographic data were only provided for $65 \%$ of those randomised. The randomisation code in Abrams 1993 was broken early due to significant desaturations in the study and there was a subsequent change to the protocol reducing the high dose sufentanil $1.5 \mu \mathrm{g} / \mathrm{kg}$ to $1.0 \mu \mathrm{g} / \mathrm{kg}$. In Moreira 2013 it was not clear if the no sedation group had a placebo intervention or no intervention at all. The remainder of studies was assessed as at low risk of other bias.

\section{Overall risk of bias}

See Figure 2. Of the 50 trials included in this review, only one was assessed as being at low risk of bias overall (Singh 2014). Nine trials $(18 \%)$ were assessed as being at unclear risk of bias (Bui 2002; Gomes 2017; Isik 2008a; Isik 2008b; Lahoud 2002; McKee 1990; Mortazavi 2009; Somri 2012; Wan 2006) and in the remaining 40 trials $(81 \%)$ at least one domain was assessed as being at high risk of bias. 
Figure 2. Risk of bias summary: review authors' judgements about each risk of bias item for each included study.

\begin{tabular}{|c|c|c|c|c|c|c|c|c|}
\hline & 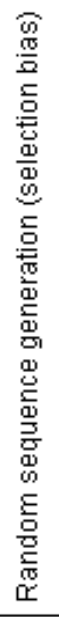 & 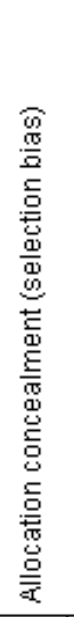 & 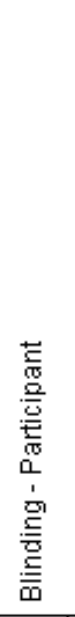 & 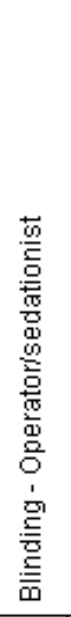 & 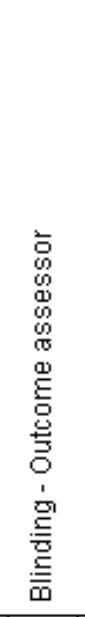 & 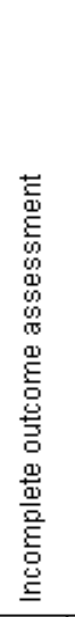 & 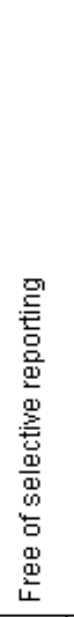 & 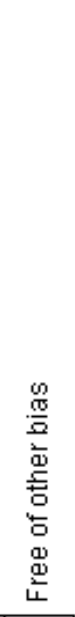 \\
\hline Abrams 1993 & $?$ & $?$ & $\odot$ & $?$ & $\theta$ & $\odot$ & $\odot$ & $?$ \\
\hline Alfonzo-Echeverri 1993 & $?$ & $?$ & $\oplus$ & + & $\odot$ & $\oplus$ & $\oplus$ & $\odot$ \\
\hline Al-Rakaf 2001 & $?$ & $?$ & + & + & + & $\odot$ & + & O \\
\hline Avalos-Arenas 1998 & $?$ & $?$ & + & $\odot$ & $\odot$ & $\odot$ & + & 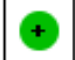 \\
\hline Averley $2004 a$ & + & + & $\odot$ & + & $\odot$ & $\theta$ & $\theta$ & $?$ \\
\hline Averley 2004b & + & $\odot$ & + & $\odot$ & $\odot$ & $\odot$ & $\odot$ & - \\
\hline Aydintug 2004 & $?$ & $?$ & $\odot$ & $\odot$ & - & $\odot$ & $\odot$ & + \\
\hline Baygin 2010 & $?$ & $?$ & 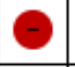 & $\odot$ & $\odot$ & $\odot$ & $\odot$ & 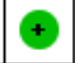 \\
\hline Bhatnagar 2012 & $?$ & $?$ & $?$ & $?$ & $?$ & $?$ & $\odot$ & - \\
\hline Bui 2002 & $?$ & $?$ & + & $\odot$ & $\odot$ & $\odot$ & $\odot$ & + \\
\hline Eshghi 2016 & $\odot$ & $?$ & $\odot$ & $\Theta$ & $\odot$ & $\odot$ & $\odot$ & - \\
\hline Faytrouny 2007 & $?$ & $?$ & $\Theta$ & $\odot$ & $?$ & $\Theta$ & $\odot$ & + \\
\hline Gallardo 1994 & $?$ & $?$ & $\odot$ & $\Theta$ & $\odot$ & $\odot$ & + & + \\
\hline Gomes 2017 & + & $\odot$ & $\odot$ & $\odot$ & + & $\odot$ & $\odot$ & $?$ \\
\hline Isik 2008a & $?$ & $?$ & $\odot$ & $\odot$ & $\odot$ & $\odot$ & + & + \\
\hline Isik 2008b & $?$ & $?$ & $\odot$ & $\odot$ & $?$ & + & + & + \\
\hline Jensen 1999 & $?$ & $\odot$ & $\odot$ & $\odot$ & $\odot$ & $\odot$ & + & + \\
\hline Kapur 2004 & $?$ & $?$ & $\odot$ & $\odot$ & $\odot$ & $\odot$ & $\odot$ & + \\
\hline Kaviani 2015 & $?$ & $?$ & $?$ & + & + & 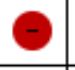 & $\odot$ & $\theta$ \\
\hline Koirala 2006 & $?$ & $?$ & $\odot$ & $\odot$ & $\odot$ & $\Theta$ & $\odot$ & $\odot$ \\
\hline Lahoud 2002 & $?$ & $\odot$ & $?$ & $?$ & $?$ & + & $\odot$ & + \\
\hline Lam 2005 & $?$ & $?$ & 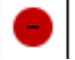 & 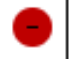 & $\odot$ & 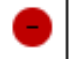 & + & - \\
\hline
\end{tabular}


Figure 2. (Continued)

\begin{tabular}{|c|c|c|c|c|c|c|c|c|}
\hline Lam 2005 & $?$ & $?$ & $\Theta$ & $\theta$ & + & $\Theta$ & + & O \\
\hline Lee-Kim 2004 & ? & $\odot$ & - & 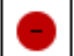 & + & $\odot$ & + & $\odot$ \\
\hline Malhotra 2016 & + & $\odot$ & $?$ & + & + & $?$ & + & 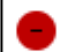 \\
\hline McKee 1990 & $?$ & $?$ & + & $\odot$ & + & + & + & + \\
\hline Meyer 1990 & $?$ & $?$ & $?$ & 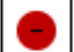 & + & - & + & + \\
\hline Moody 1986 & $?$ & $?$ & - & 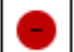 & - & $\odot$ & + & + \\
\hline Moore 1984 & $?$ & $?$ & + & + & + & $\odot$ & + & + \\
\hline Moreira 2013 & + & + & - & $\theta$ & - & + & + & C \\
\hline Mortazavi 2009 & $?$ & $?$ & + & $\odot$ & + & + & + & $?$ \\
\hline Nathan 1988 & $?$ & $?$ & $?$ & $?$ & + & ? & + & $\theta$ \\
\hline Özen 2012 & ? & $?$ & $?$ & $?$ & $?$ & O & + & $\theta$ \\
\hline Park 2006 & ? & $?$ & - & $\theta$ & + & + & + & + \\
\hline Rai 2007 & ? & $?$ & $?$ & $?$ & $?$ & $\Theta$ & + & $?$ \\
\hline Reeves 1996 & ? & ? & $\odot$ & + & + & $\Theta$ & + & + \\
\hline Roelofse 1996a & $?$ & $?$ & + & $\odot$ & $\odot$ & $\odot$ & + & + \\
\hline Roelofse $1996 \mathrm{~b}$ & $?$ & ? & + & + & + & $\Theta$ & + & + \\
\hline Roelofse 1998 & $?$ & ? & $\Theta$ & + & + & $\Theta$ & + & + \\
\hline Sams 1993a & ? & $?$ & + & + & + & O & + & + \\
\hline Shanmugaavel 2016a & + & $?$ & $?$ & + & $?$ & O & + & O \\
\hline Shanmugaavel $2016 \mathrm{~b}$ & + & $?$ & $\theta$ & $\theta$ & + & + & + & + \\
\hline Shashikiran 2006 & $?$ & ? & $\Theta$ & + & + & + & + & + \\
\hline Singh 2002 & $?$ & ? & + & + & + & $\Theta$ & + & $?$ \\
\hline Singh 2014 & + & + & + & + & + & + & + & + \\
\hline Somri 2012 & + & ? & $?$ & + & $?$ & + & + & + \\
\hline Surendar 2014 & + & $\Theta$ & $\odot$ & + & $\odot$ & $\odot$ & $\odot$ & $\odot$ \\
\hline Torres-Perez 2007 & ? & $?$ & $\theta$ & $\theta$ & + & $\Theta$ & + & + \\
\hline Tyagi 2012 & ? & $?$ & $\Theta$ & $\theta$ & $\theta$ & + & + & - \\
\hline Veerkamp 1993 & ? & $?$ & $\theta$ & $\theta$ & + & + & + & $?$ \\
\hline Wan 2006 & $?$ & $?$ & + & 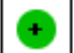 & + & + & + & $\odot$ \\
\hline
\end{tabular}

In common with many other Cochrane Reviews the overall quality of studies was found to be disappointing. Poor reporting was an obvious problem with these studies and this may have masked other defects in design or conduct of these trials.

\section{Effects of interventions}

See: Summary of findings for the main comparison Sedative compared to placebo for children needing dental care; Summary of findings 2 Sedative compared with different dosage of the same 
sedative for children needing dental care; Summary of findings 3 Sedative compared with a different sedative for children needing dental care

\section{Placebo-controlled studies}

See Additional Table 1 We included 12 placebo studies in the review.

\section{Oral midazolam}

Where possible studies were included in the meta-analysis using overall behaviour as measured by Houpt (or a scale in the same direction) as an outcome measure. Gallardo 1994 and Isik 2008a did not record Houpt but did use a similar scale (three-point as opposed to six-point). Raw data were supplied by Isik 2008a and Tyagi 2012 so these were used to calculate mean and standard deviation (satisfactory scored as 3, unsatisfactory as 1 in Isik 2008a). Gallardo 1994 reported standard error so this was converted to standard deviation. Kapur 2004 used a reversed scale so these data were transformed. Wan 2006 appeared to have a reporting error whereby test and control results were transposed. Close examination of the paper shows that values for all measures of behaviour reported in Table 2 are the opposite as described in the text i.e. they suggest the intervention worsens behaviour whereas in the text it states that patient behaviour improved. The same is not true for the physiological measures (Table 2 again), subjects in the intervention group had a significantly lower heart rate. We were unable to contact the authors therefore we have decided this most likely represents an error in reporting and have therefore transposed values for the control and intervention groups. Moreira 2013 did not report overall behaviour, instead behaviour was recorded at discrete intervals throughout the visit. In addition, behaviour was recorded using OSUBRS as opposed to a scale like Houpt (or similar). OSUBRS runs in the reverse direction to Houpt. We therefore decided not to include this study in the meta-analysis.

The results can be seen in Analysis 1.1. A fixed-effect model and standardized mean difference (SMD) was used as the scales were not completely alike. Use of oral midazolam produced a significant improvement in behaviour in all of these trials (SMD $1.96,95 \%$ confidence interval $(\mathrm{Cl}) 1.59$ to 2.33 ; $\mathrm{P}<0.0001 ; 6$ studies; 202 participants). The considerable heterogeneity $(12=90 \%, P<$ 0.00001 ) in this estimate is likely due to the different tools used to measure the outcome in each trial and the range of doses of oral midazolam used from $0.25 \mathrm{mg} / \mathrm{kg}$ to $0.75 \mathrm{mg} / \mathrm{kg}$ (see Additional Table 1). We assessed the certainty of the evidence as moderate (according to GRADE recommendations). The risk of bias was high or unclear in most studies. The remaining measures were scored as low. We could not assess the risk of publication bias. Oral midazolam probably improves behaviour (moderate-certainty evidence).

\section{Nitrous oxide/oxygen}

Two trials (Nathan 1988; Veerkamp 1993) reported changes in favour of nitrous oxide in either behaviour or anxiety, but no data were available from the Nathan trial. Data from Veerkamp 1993 was added to the meta-analysis. In this study they reported anxiety on the Venham scale which is in the opposite direction to Houpt, so scores were transformed for forest plots (Analysis 1.1). No adverse effects were mentioned. We assessed the certainty of evidence as very low (according to GRADE recommendations) due to the risk of bias and imprecision. We are uncertain whether nitrous oxide/ oxygen improves behaviour (very low-certainty evidence).

\section{Chloral hydrate (CH)}

There was no statistically significant increase in positive behaviour between placebo and any of the oral chloral hydrate groups, and all participants completed treatment regardless of group (Moore 1984). There was no statistically significant difference between placebo and the three active chloral hydrate groups combined for the outcome of positive behaviour during the operatory (Analysis 1.2), possibly due to a strong response to the placebo. However, after nitrous oxide/oxygen was administered, there were airway issues with four children (27\%) in the $60 \mathrm{mg} / \mathrm{kg}$ chloral hydrate group not responding to obstruction. We are uncertain whether chloral hydrate improves behaviour as the certainty of the evidence has been assessed as very low due to the risk of bias, incomplete outcome assessment and imprecision. We could not assess the risk of publication bias.

\section{Meperidine}

Meperidine was statistically significantly more effective $(P<0.05)$ than placebo for the outcome of good or better behaviour (good, very good or excellent behaviour) ( $71 \%$ in meperidine groups compared to $13 \%$ in placebo) (Analysis 1.2.). However, two patients in the meperidine groups (13\%) had unmanageable behaviour and treatment had to be aborted and rescheduled. Nausea and vomiting were more frequent in the meperidine groups (38\% versus $7 \%$ ) and rates showed a dose response (McKee 1990). Meperidine may improve behaviour (low-certainty evidence due to unclear risk of bias and imprecission).

\section{Intravenous midazolam}

Overall behaviour was significantly better in this group when compared to placebo $(P=0.01)$ (Analysis 1.1) (Tyagi 2012). However, we are uncertain whether intravenous midazolam improves behaviour as the certainty of the evidence has been assessed as very low due to high risk of bias and imprecision. We could not assess the risk of publication bias.

\section{Oral diazepam}

Overall behaviour was not significantly better in this group when compared to placebo $(P=0.18)$ (Analysis 1.1, Tyagi 2012). No adverse effects were reported. We are uncertain whether oral diazepam improves behaviour (very low-quality/certainty evidence).

\section{Midazolam/ketamine}

$0.5 \mathrm{mg} / \mathrm{kg}$ midazolam with $3 \mathrm{mg} / \mathrm{kg}$ ketamine produced significantly better behaviour (as measured by the sum of the OSUBRS score at each measurement point) than the placebo and oral midazolam $(P=0.03$ ) (Moreira 2013). Because of the way these data were presented, we were unable to include them in the metaanalysis.

\section{Dose comparison studies}

See Additional Table 2. Ten studies compared different dosages or routes of admission of sedative agents.

\section{Hydroxyzine}

Faytrouny 2007 reported no differences between groups at any of the time points measured. No adverse effects were reported. 


\section{Midazolam (intranasal)}

Al-Rakaf 2001 found that behaviour improved in the group receiving $0.5 \mathrm{mg}$ intranasal midazolam compared to either $0.3 \mathrm{mg} / \mathrm{kg}$ or $0.4 \mathrm{mg} / \mathrm{kg}$ (Analysis 4.1), but there was no statistically significant improvement in behaviour between $0.4 \mathrm{mg}$ group and $0.3 \mathrm{mg}$ group. The number of patients completing treatment increased also $(79 \%, 96 \%$ and $100 \%$ in groups 1, 2 and 3 respectively - data from fasting children were used). Authors also reported that fasting made no difference to overall behaviour $(P=0.8286)$.

Lee-Kim 2004 found no differences between groups in mean Houpt behaviour score at any of the times measured - data not available $(P=0.749)$. As expected, mean time to onset of sedation was much shorter in the intranasal group, but mean duration of sedation (working time) was statistically significantly longer in the group who received oral midazolam (Additional Table 2).

Lam 2005 reported that there was improved behaviour at time of delivery of local anaesthetic and venepuncture in the intramuscular group, and good or excellent sedation was achieved in all of the intramuscular group compared to only $6 / 11(54 \%)$ of the intranasal group (Analysis 4.1).

Shashikiran 2006 reported no difference with regard to behaviour between the intramuscular and intranasal groups, which both showed improvement from baseline. Induction of sedation, treatment and recovery however was faster in the intranasal group (Analysis 4.1). Despite receiving a light snack prior to treatment, none of the children vomited.

Shanmugaavel 2016a reported a decrease in the anxiety after 20 minutes of the sedatives administration in both groups. Although the intranasal group showed more statistically significant decrease in anxiety at various set points during treatment compared to the sublingual group. They could not show a link between measuring salivary cortisol levels and detection of anxiety.

Adverse effects were reported by Al-Rakaf 2001 and Shashikiran 2006 and included sneezing, coughing, diplopia and hiccups.

\section{Midazolam (oral)}

Aydintug 2004 found oral and rectal midazolam to be equally effective with no differences in behaviour between the groups (Additional Table 2). However, acceptance of rectal administration by the children was much poorer when compared to oral administration.

Isik 2008b reported that children receiving $0.75 \mathrm{mg} / \mathrm{kg}$ or $1 \mathrm{mg}$ had a statistically significantly greater sedation score compared to those receiving $0.2 \mathrm{mg} / \mathrm{kg}$ or $0.5 \mathrm{mg} / \mathrm{kg}(\mathrm{P}<0.05)$ (Analysis 4.1). Sedation was considered inadequate in $86 \%, 38 \%, 23 \%$ and $38 \%$ of children in groups 1 to 4 respectively. Three children in group $4(1 \mathrm{mg} / \mathrm{kg})$ had delayed recovery time and in one patient a desaturation. Hypoxaemia, vomiting and nausea were reported as adverse effects. Authors recommended the $0.75 \mathrm{mg} / \mathrm{kg}$ dose as providing adequate sedation with good recovery time and few adverse effects.

Somri 2012 reported significant difference in sedation scores with $0.75 \mathrm{mg} / \mathrm{kg}$ and $1 \mathrm{mg} / \mathrm{kg}$ having higher scores compared to $0.5 \mathrm{mg} /$ $\mathrm{kg}$. No statistically significant difference was found in the sedation score of $0.75 \mathrm{mg} / \mathrm{kg}$ and $1 \mathrm{mg} / \mathrm{kg}$ groups. Behavioural co-operation was better in the $1 \mathrm{mg} / \mathrm{kg}$ group followed by $0.75 \mathrm{mg} / \mathrm{kg}$ and 0.5 $\mathrm{mg} / \mathrm{kg}$ groups. There was no difference in the duration of treatment between the groups although completion of treatment scores were better in the $1 \mathrm{mg} / \mathrm{kg}$ group. Discharge times were the shortest in the $0.5 \mathrm{mg} / \mathrm{kg}$ group followed by the $0.75 \mathrm{mg} / \mathrm{kg}$ group and the longest in the $1 \mathrm{mg} / \mathrm{kg}$ group. Adverse effects of respiratory events and nausea and drowsiness were noted more as the dose of midazolam increased. Authors recommended the $0.75 \mathrm{mg} / \mathrm{kg}$ as the optimal dose for effectiveness, acceptability and safety.

\section{Head-to-head drug comparison studies}

See Additional Table 3. Thirty-one included studies compared different drugs and delivery methods.

\section{Chloral hydrate/hydroxyzine}

Avalos-Arenas 1998 found significantly decreased crying and movement, but higher rates of oxygen desaturations and deep sedation in the chloral hydrate/hydroxyzine group. Overall there was no statistically significant difference between the groups at the time of giving the local anaesthetic injection (Analysis 2.1 and Additional Table 3). All participants completed treatment in both groups.

Meyer 1990 reported that both regimens resulted in similar sedation (Additional Table 3) and one child in the chloral hydrate/ hydroxyzine group experienced vomiting.

In the trial by Moody 1986 good or excellent sedation was achieved by $70 \%$ of children in both the rectal chloral hydrate and oral chloral hydrate/hydroxyzine groups suggesting that these two regimens have equivalent sedative effects compared to oral chloral hydrate alone which resulted in good/excellent sedation in $40 \%$ of children, but the difference was not statistically significant (Analysis 2.2 and Additional Table 3).

In Park 2006 subjects in the chloral hydrate/midazolam group showed better overall behaviour as measured by Houpt $(P=0.004)$ and less restraint was required in the chloral hydrate/midazolam group $(\mathrm{P}<0.05)$.

Reeves 1996 reported no difference in the mean overall behaviour score in each group (Analysis 2.1), though the authors noted that children in the chloral hydrate/hydroxyzine group were in a significantly deeper sleep $(P=0.0015)$. Treatment was aborted for one participant in the chloral hydrate/hydroxyzine group, and $60 \%$ of children in the chloral hydrate/hydroxyzine group compared with $55 \%$ of children in the midazolam/acetaminophen group had an overall evaluation of good or better sedation, a difference which was not statistically significant. This suggests that the regimens were similar in terms of effective sedation, but approximately $40 \%$ of procedures were still difficult.

In the trial by Torres-Perez 2007 chloral hydrate/hydroxyzine resulted in "quieter" sedation as measured by OHSBRS and mean cardiac rate in each group. Authors did not provide any estimates of statistical significance but comment that although hydroxyzine alone was "not controllable", the addition of either choral hydrate or midazolam resulted in similarly enhanced sedative effects (Additional Table 3). 


\section{Chloral hydrate/promethazine}

In Sams 1993a three patients did not actually receive nitrous oxide because of their behaviour (one in the chloral hydrate/ promethazine group displayed excellent behaviour and nitrous oxide was not required, and two children in the meperidine/ promethazine group exhibited extreme head body movements such that the hood could not be used). The authors describe that over all 10 time points there was a statistically significantly greater likelihood that children were drowsy or asleep rather than awake and alert in the choral hydrate/promethazine group, but at the time the local anaesthetic injection was administered there was no difference between the two groups (Analysis 2.1). Differences between the groups in movement, crying and overall scores statistically significantly favoured the choral hydrate/ promethazine group at $40 \%$ of the time points measured and in the remainder there was no difference (Sams 1993a). Both groups completed all planned treatment and there was no difference in mean duration of treatment (Additional Table 3). No adverse effects were reported.

\section{Dexmedetomidine}

Surendar 2014 reported no significant difference in overall behaviour, overall success rate of treatment and distribution of sedation levels between the groups. Midazolam had statistically significant higher intra and post-operative analgesia scores compared to the other groups. Significant difference in onset time, recovery time, pulse rate and systolic blood pressure of the two dexmedetomidine groups compared to the midazolam and ketamine groups was observed. The authors concluded that all the interventions can be used safely and effectively.

\section{Ketamine}

Abrams 1993 reported that both ketamine and midazolam induced the same mean sedation score of 4 (where 5 is ideal) and both had short recovery times ( $7 \pm 7$ and $3 \pm 2$ minutes respectively). Use of sufentanil resulted in heavily sedated children and oxygen desaturations; desaturations were of such concern that the operators broke the code during the study to determine which drug was the cause $(1.5 \mu \mathrm{g} / \mathrm{kg}$ sufentanil in all four cases). Authors concluded that both intranasal ketamine $(3 \mathrm{mg} / \mathrm{kg}$ ) and midazolam $(0.4 \mathrm{mg} / \mathrm{kg})$ resulted in acceptable sedation in children.

Rai 2007 found that ketamine showed higher mean overall behaviour scores when compared to either midazolam or propofol (Additional Table 3, Analysis 3.1).

When rectal ketamine $(5 \mathrm{mg} / \mathrm{kg}) /$ midazolam $(0.35 \mathrm{mg} / \mathrm{kg})$ was compared to rectal midazolam ( $1 \mathrm{mg} / \mathrm{kg}$ ) alone (Roelofse 1996a), both regimens were well accepted by $78 \%$ and $70 \%$ of children, and only one child in the combination group experienced nausea. The combined regimen resulted in a statistically significant improvement in behaviour. Excessive salivation was reported in $26 \%$ and $14 \%$ and hallucinations in $14 \%$ and $42 \%$ of children in the midazolam only and ketamine/midazolam groups respectively (Roelofse 1996a). In this study treatment was aborted in one patient $(2 \%)$ in the ketamine/midazolam group (Additional Table 3).

In a second study (Roelofse 1996b) very good or excellent sedation was achieved in $80 \%$ of the SOP (trimeprazine/physeptone/ droperidol) group and $93 \%$ of the ketamine group (Analysis 3.2) but this difference was not statistically significant. Overall evaluation, which was more subjective, was good/very good in $67 \%$ of the SOP group and $90 \%$ of the ketamine group, a difference that was statistically significant (Additional Table 3). There were more adverse effects in the ketamine group (Additional Table 3) but all participants in both groups completed treatment.

The third trial by this group (Roelofse 1998) compared oral ketamine $(5 \mathrm{mg} / \mathrm{kg})$ plus midazolam $(0.35 \mathrm{mg} / \mathrm{kg})$ with a combination of oral trimeprazine $(3 \mathrm{mg} / \mathrm{kg})$ and methadone $(0.2$ $\mathrm{mg} / \mathrm{kg}$ ) administered 30 minutes prior to dental treatment. In the group receiving the ketamine/midazolam combination, $46 \%$ of children were "oriented and calm" at the start of dental treatment compared to $84 \%$ in the other group (Analysis 3.2). However, the more subjective outcome of overall sedation was rated as good or very good in $94 \%$ of children in the ketamine/midazolam group compared to $78 \%$ in the trimeprazine/methadone group, a statistically significant difference favouring ketamine. However, adverse outcomes of vomiting (4\%) and hallucinations (20\%) were only observed in the ketamine/midazolam group in this trial.

Alfonzo-Echeverri 1993 found no statistically significant difference in the distribution of sedation outcomes between the groups (Additional Table 3; Analysis 3.1), however four children (20\%) had treatment aborted in the meperidine/promethazine group compared to none in the ketamine group. Eight children (40\%) in the ketamine vomited, half of them during treatment and the remainder during recovery.

In the trial by Bui 2002 there was a statistically significant difference in mean Houpt behaviour score favouring ketamine (Analysis 3.1) compared to ketamine/promethazine. In one child, planned treatment was aborted (ketamine/promethazine group) but vomiting was only observed in the ketamine group $(n=3,27 \%)$.

Singh 2014 showed that oral dexmedetomidine at $5 \mu \mathrm{g} / \mathrm{kg}^{-1}$ had the most "adequate" depth of sedation and "satisfactory" completion of treatment, but had no statistically significant difference compared to the other groups. Ketamine $8 \mathrm{mg} / \mathrm{kg}^{-1}$ and dexmedetomidine at $5 \mu \mathrm{g} / \mathrm{kg}^{-1}$ had a quicker onset time, prolonged recovery time, and better intra and post-operative pain score compared to the other groups. Ketamine resulted in more profound retrograde amnesia. $25 \%(n=7)$ sessions with ketamine resulted in adverse effects of vomiting and hallucinations, whereas one patient on dexmedetomidine at $5 \mu \mathrm{g} / \mathrm{kg}^{-1}$ reported vomiting.

\section{Midazolam (oral)}

Baygin 2010 reported that all premedication agents produced better behaviour than just nitrous oxide at all time points (Analysis 4.1). Ramsay sedation scores were statistically significantly greater in midazolam plus nitrous oxide group compared to nitrous oxide alone $(P<0.05)$ (Analysis 4.1). There was no statistically significant difference found between midazolam plus nitrous oxide and either hydroxyzine (Analysis 4.1) or midazolam/ketamine (Analysis 4.1). A wide variety of adverse effects were recorded including nausea/ vomiting, cough, hiccup, enuresis, bronchospasm, hypersalivation, otalgia, hallucination and epistaxis (Additional Table 3).

Bhatnagar 2012 noted better depth of sedation and ease of treatment in the midazolam and tramadol groups compared to the other interventions. Ease of treatment scores between midazolam, tramadol and triclofos were not significantly different. The authors 
concluded that midazolam followed by tramadol is best to produce sufficient levels of sedation.

Koirala 2006 reported the most favourable sedation scores in the group receiving midazolam plus ketamine followed by the group receiving midazolam plus tramadol (data only presented graphically in paper) (Additional Table 3). No adverse effects were reported.

Malhotra 2016 found significant difference in improvement of behaviour during treatment compared to baseline in the two groups. Significant difference in the level of sedation in group 1 and group 2 when a comparison is made at specific time stages (treatment-baseline and end of treatment-baseline) (e.g. for group 1 treatment-baseline comparison shows significant difference $(P=$ 0.002 ) in the level of sedation). No significant difference in sedative efficacy or anxiolysis potential. The authors concluded that success of sedation and ease of treatment was higher in the midazolam/ ketamine group compared to the dexmedetomidine group.

Moreira 2013 noticed significant differences in behaviour with the midazolam/ketamine group having better behaviour compared to the midazolam group and the no sedation group. All groups showed the same behavioural pattern at the end of the treatment session. Adverse reactions of agitation and vomiting were reported in the midazolam/ketamine group.

Özen 2012 found the highest scores for behaviour for the intranasal midazolam/nitrous oxide followed by oral midazolam $0.75 \mathrm{mg} /$ $\mathrm{kg}$ and nitrous oxide, oral midazolam $0.50 \mathrm{mg} / \mathrm{kg}$ and nitrous oxide and lastly the inhalation sedation nitrous oxide group. Overall success of operative treatment was significantly better in the intranasal midazolam/nitrous oxide group compared to oral midazolam $0.50 \mathrm{mg} / \mathrm{kg}$ and nitrous oxide. Between the intranasal midazolam/nitrous oxide and oral midazolam $0.75 \mathrm{mg} / \mathrm{kg}$ and nitrous oxide group no significant difference was reported. This was similar to the two oral midazolam groups where no significant difference was reported. Inhalation sedation with nitrous oxide group showed the least success rate compared to all other groups. Depth of sedation was measured using bispectral index (BIS) values. Oral midazolam $0.75 \mathrm{mg} / \mathrm{kg}$ and nitrous oxide group was most sedated except for at 30 minutes after initiation of sedation. From 15 minutes after initiation of sedation to the end of treatment in all groups had BIS values were above 90 and therefore the patients were awake. Recovery time in minutes was shorter for intranasal midazolam compared to oral midazolam groups. Adverse effect reported in the oral midazolam group was of vomiting. In the intranasal group nose bleeding, along with transient burning and discomfort was reported. After discharge irritability, crying, sleepiness and nausea were recorded. The authors concluded that both oral and intranasal midazolam in conjugation with nitrous oxide can be used to achieve moderate sedation.

Singh 2002 sedation scores were reported on an eight-point scale in which a high score indicated poor sedation. In order to use these data in meta-analysis (Analysis 4.1) scores were transformed and standard deviations were calculated (Additional Table 3). No adverse effects were reported.

Tyagi 2012 reported that the overall behaviour rating was significantly better in the intravenous midazolam group compared to other groups. Positive behaviour postsedation was significantly approved in the intravenous midazolam group compared to the other groups, no significant difference was reported between the oral midazolam and the oral diazepam. This study did not report standard deviations for the overall behaviour. However, as raw data were reported, these could be calculated.

\section{Midazolam (intravenous)}

In Eshghi 2016 bispectral index system values noted for the ketamine/midazolam/propofol group were all in the range of general anaesthesia, whereas for the remifentanil/midazolam/ propofol group at 15 minutes postadministration of the sedation the values were in the range of general anaesthesia. The ketamine/ midazolam/propofol group were more deeply sedated compared to the remifentanil/midazolam/propofol group, the difference was statistically significant. Dental Sedation Teachers Group scale (DSTG) in both groups was noted as 5 (eyes closed, no response to mild physical stimulus) during the treatment. Heart rate and respiratory rate showed no significant difference between the two groups. Remifentanil/midazolam/propofol group showed quicker recovery. Adverse effects of severe nausea and vomiting was reported in the remifentanil group. The authors concluded that the remifentanil/midazolam/propofol group produced effective and safe sedation with a shorter recovery time.

Kaviani 2015 noted no significant difference in the sedation score or score of operative conditions at specific time intervals. The authors concluded that there was no difference between the two interventions

\section{Midazolam (rectal)}

Jensen 1999 at 10 minutes found no significant difference in sedation level between the groups. After 1 hour there was a statistically significant difference favouring diazepam. More children were agitated with diazepam at 1 hour when comparing rectal midazolam to rectal diazepam (data only presented graphically in paper) (Additional Table 3).

\section{Sevoflurane}

Lahoud 2002 compared sevoflurane $(0.1 \%$ to $0.3 \%)$ /nitrous oxide $(40 \%)$ with nitrous oxide (40\%) alone. There was a statistically significant difference in rate of effective sedation favouring the sevoflurane/nitrous oxide group $(P<0.001)$ (Additional Table 3).

Averley 2004a was a pilot study which randomised children to either intravenous midazolam $(0.5 \mathrm{mg} / \mathrm{min})$ titrated to induce adequate sedation, or $40 \%$ nitrous oxide inhalation plus intravenous midazolam $(0.5 \mathrm{mg} / \mathrm{min})$ titrated to induce adequate sedation, or inhalation of $0.3 \%$ sevoflurane plus $40 \%$ nitrous oxide plus intravenous midazolam $(0.5 \mathrm{mg} / \mathrm{min})$ titrated to induce adequate sedation. Treatment was successfully completed in 50\%,73\% and $83 \%$ of children in each group respectively and researchers noted that nine of the 16 children in groups 1 or 2 who failed were subsequently successfully treated with the addition of sevoflurane and nitrous oxide (Additional Table 3).

In the subsequent trial (Averley 2004b) the same interventions were used as in the pilot study and treatment completion rates were $54 \%, 80 \%$ and $94 \%$ for groups 1 to 3 respectively. Vomiting only occurred in group 3, but incidence was low $(n=6,2 \%)$ (Additional Table 3). 


\section{DISCUSSION}

\section{Summary of main results}

See Summary of findings for the main comparison; Summary of findings 2; and Summary of findings 3.

In common with the findings from many other systematic reviews, the design and reporting of studies included in this review was mostly poor. In general, the risk of bias for most studies was at best a mix of low and unclear (18\% of included trials) and likely to have at least one domain that was high ( $82 \%$ of included trials). Combining data from included studies to facilitate a metaanalysis was difficult. The enormous range of sedative agents used both in combination and singly, along with the wide range of outcome measures, precluded meta-analysis of homogenous groups of interventions.

\section{Placebo-controlled studies}

It was possible to carry out a meta-analysis for studies comparing oral midazolam with placebo (Analysis 1.1). There is consistent evidence from six heterogeneous trials, that following administration of oral midazolam the behaviour of children was improved relative to placebo, with variations in the size of the benefit according to the dosage used. Where reported, adverse effects were few and minor. This effect was considered to be moderately sized and of moderate certainty according to the GRADE recommendations.

\section{Dose comparison studies}

Intranasal midazolam was evaluated in four studies, but the comparators and dosages were different and results conflicting. There is insufficient evidence to determine whether any specific dose of intranasal midazolam is effective.

There is weak evidence from two trials that oral midazolam at a dose of $0.5 \mathrm{mg} / \mathrm{kg}$ to $0.75 \mathrm{mg} / \mathrm{kg}$ is an effective sedative for children. However, one trial administered both nitrous oxide and midazolam so it is difficult to attribute benefit to midazolam alone.

\section{Head-to-head drug comparison studies}

In this group no two studies evaluating the same intervention and comparison found the same effect. There is insufficient evidence to draw any conclusions from these trials.

\section{Adverse effects}

There is insufficient evidence from trials in this review to support the effectiveness of either chloral hydrate or ketamine. However, it should be noted that chloral hydrate was associated with significant adverse effects, specifically airway issues especially when high doses (> $50 \mathrm{mg} / \mathrm{kg}$ ) were combined with the use of inhalational nitrous oxide. Ketamine was also associated with significant adverse effects.

\section{Overall completeness and applicability of evidence}

It was apparent whilst carrying out this review that there were significant differences in techniques and drugs used between countries and regions. Studies can be loosely grouped into two types, those based on a 'North American' model of sedation and those based on a more 'European' model. The North American model was typified by use of multiple agents (including adjunctive nitrous oxide) at any age, the use of restraint and intent to induce a deeper level of sedation. The European model was typified by use of single agents (typically nitrous oxide or midazolam) with intent to induce lighter levels of sedation. This is most likely due to cultural and legal differences and needs to be considered when making recommendations for the most effective methods of conscious sedation.

Interpretation of outcome data related to behaviour was difficult. Over half of the studies used the Houpt or a modified Houpt scoring system to record behaviour, however the remaining studies used a wide variety of methodologies. Even within studies using modified versions of the Houpt scale, there was a large variation in how Houpt was modified. Behaviour was recorded in some studies for the whole episode and in others at a series of discrete points such as application of local anaesthetic or venepuncture. Furthermore, many of the outcome measures used relied on observations of movement, yet in a large proportion of studies patients were restrained in a papoose board. It is difficult to determine how this might have influenced recorded values of behaviour. Interestingly participants often completed treatment regardless of which group they were assigned to. This might reflect a lack of baseline anxiety in all participants which then begs the question as to why they were included in the study. Alternatively given the use of papoose boards and supplemental nitrous oxide oxygen perhaps it is not surprising.

The efficacy of a particular agent will be influenced by the baseline anxiety of the child involved. Ideally this should always be recorded and then compared to levels of anxiety after sedation. Baseline values of anxiety were not uniformly reported and very few studies recorded anxiety at the end.

The majority of studies involved sedation in children less than 6 years of age, probably because this age range belongs to a 'preco-operative' group. Treatment needs and management of children will vary as they grow and develop. Techniques that are appropriate in a 3-year old may not be appropriate in a 12-year old and vice versa.

In most papers the medical status of the children was healthy or having mild systemic disease (American Society of Anesthesiologists (ASA) physical status classification system: ASA I and ASA II). Some of the techniques described may be useful in the management of medically compromised patients, but at present there are no studies carried out in these groups.

Little information was provided on restorative treatment carried out in many of the studies, although several articles mentioned the use of local anaesthesia, mouth prop and rubber dam. Obviously the treatment provided may well influence the behaviour and anxiety of the participant.

\section{Quality of the evidence}

In general reporting of the trials was poor with data such as method of sequence generation and allocation concealment frequently not reported. Participants were poorly described with important information such as gender or weight often missing. Sample size calculations were either not carried out or not reported, and it is likely that many of the trials lacked statistical power to detect a difference between intervention and control. This would then result in significant imprecision. Statistical methods used varied widely between studies even though outcome measures were sometimes 
similar. In some instances these tests were arguably inappropriate for the types of data usually produced by these studies.

\section{Potential biases in the review process}

In a previous update (Matharu 2012) the decision was made to exclude cross-over trials. Cross-over trials were excluded as they are not an appropriate study design when the intervention can have a lasting effect (Cochrane Handbook for Systematic Reviews of Interventions Section 16.4.2, Higgins 2011). It is well recognised that previous treatment episodes influence the anxiety associated with dental treatment, especially in children. Evidence to support this can be found in Veerkamp 1995. In this study, anxiety in children who received a treatment phase under nitrous oxide was compared with children who received treatment without nitrous oxide approximately 72 weeks after the first phase. They found that overall and peak scores for anxiety were significantly reduced $(\mathrm{P}<$ 0.05 ) in the nitrous oxide group at the start of the second treatment phase when compared to the control group. This decision resulted in a significant proportion of included studies from earlier versions becoming excluded. We felt this approach was justified.

\section{Agreements and disagreements with other studies or reviews}

A related review was published by the National Institute for Health and Care Excellence (NICE) on sedation in children and young people (NICE 2010). It was different from this Cochrane Review in that it considered sedation for any medical or dental therapeutic procedure, and it also was restricted to procedures that could be used within the regulatory framework of England and Wales. Randomised controlled trials with less than 20 subjects were excluded, cross-over studies were included. NICE 2010 recommended for dentistry that only midazolam or nitrous oxide be used. In common with this review they found "surprisingly few high-quality published reports and clinical trials."

\section{AUTHORS' CONCLUSIONS}

\section{Implications for practice}

There is moderate-certainty evidence from six trials that oral midazolam is an effective agent for sedation of children. Although other sedatives have been evaluated, the range of sedatives, regimens, doses, modes of administration and comparisons included makes it impossible to produce a clear statement of implications for practice regarding other agents.

\section{Implications for research}

This is the second update of the Cochrane Review first published in 2005 and previously updated in 2012. It is unfortunate that there has been little improvement in the design, statistical power and reporting of studies carried out since then.

The shortfalls of studies reported in this review are many. The principles that researchers should adhere to when designing, carrying out and reporting clinical trials in the future are the CONSORT guidelines (Moher 2001). There also needs to be a improvement in reporting of variables like gender, weight, time starved, time of onset of sedation, dropouts, reason for patient failing to complete treatment, etc.
More specific recommendations for studies assessing sedative agents are as follows.

\section{Blinding}

Ideally the operator, participant and assessor should all be blinded to the sedation agent used, however blinding of the operator is problematic. When comparing drugs with different modes of delivery e.g. oral midazolam versus nitrous oxide/oxygen, it would not be possible to blind the operator as techniques of administration are totally different. If this is the case then it is important that the assessor is blinded to the allocation. In the aforementioned example this could be achieved by using an inhalation mask to deliver air in the midazolam group and the patient videotaped, to enable blinded outcome assessment.

\section{Sample}

Obviously calculating and reporting sample sizes should be carried out before starting any clinical trial, something that has not been done well to date in trials of sedation agents in children requiring dental treatment. More consideration also needs to be given to the children included in trials, in particular their age. Consideration should be given to dividing age into three broad groups (as recommended by the British National Formulary (BNF) when prescribing drugs to children). These groups are: from 1 to 6 years, from 6 to 12 years and over 12 years of age. There is a need to establish which sedation is more effective for a given age group.

Consideration should also be given to the reasons for sedation which may well vary widely between groups. In pre-co-operative children (under 6) the intention is often to get treatment done. In older children (e.g. over 12) the intention might be to provide a pleasant experience for the patient thus reducing anxiety for further visits. It would also be helpful for research to investigate suitable sedative regimens for dental treatment in medically compromised children of various ages, those with learning difficulties or other behavioural problems such Attention Deficit Hyperactivity Disorder (ADHD).

\section{Design}

Only studies of a parallel design should be carried out. Cross-over trials are not appropriate because the level of baseline anxiety/ behaviour in the second treatment phase is highly dependent on the success or otherwise of the first treatment period.

\section{Baseline and outcome variables}

Behaviour is the most commonly used outcome measured in a range of ways. Anxiety is sometimes measured before the study commences but rarely afterwards. Treatment completion is not always reported and very rarely statistically tested between groups. Outcome variables are very clinician centred - what was the quality of the sedation? How immobile was the child? etc. These approaches need to change.

Outcome variables need to be more patient-centred. This might include satisfaction, reduction in anxiety or other measures relating the patient's perception.

A wider debate needs to be had on the purpose of sedation. The majority of studies to date, focus on the use of sedation as a tool to facilitate the delivery of dental treatment in children. This is important; but sedation could (and should) have a larger 
role. It could be used to facilitate the introduction of treatment to anxious children with a view to reducing or removing sedation in subsequent visits (an approach taken by Veerkamp 1993). Outcome variables should be chosen to reflect this.

Where behaviour-type outcome measures are used, thought must be given to the appropriateness of movement-based measures for children who are restrained e.g. by a papoose board.

Considering the above comments the review authors would suggest that reviews have the following 'key' or 'core' variables in common to allow comparison between studies in future.

1. Some measurement of baseline anxiety.

2. Completion of treatment as the primary outcome variable.

3. Patient satisfaction or preference.

\section{Deep versus conscious sedation}

It was originally intended to exclude any papers that dealt with deep sedation for reasons outlined in the introduction. This proved to be impossible because many papers did not state explicitly whether they were practicing conscious or deep sedation, sleeping was also poorly reported. We believe that in some of these papers deep sedation was undertaken, as participants were reported as falling asleep and mouth props were used. This highlights the importance of reaching a consensus definition of conscious sedation, or at the very least using the definitions already available. Without this information it is impossible for researchers or clinicians in countries where the existing regulatory framework does not permit deep sedation to make appropriate use of published data. Alternatively the definition of deep sedation could be abandoned, as it is not used.

\section{Agents/regimens under test}

There are 32 sedative drugs or drug combinations tested for conscious sedation in this review, given either orally, by inhalation, intramuscular injections, intranasally and/or rectally and at varying dosages. The majority were not compared against a placebo or even a drug of known efficacy. Future trials should consider the use of either oral midazolam or nitrous oxide sedation as a comparator.
As mentioned, not all agents are available in all countries and the choice of sedation will depend on cultural acceptance and also laws and availability. It would seem appropriate to identify agents of particular interest and co-ordinate research on these internationally. Furthermore, it would seem appropriate for different countries to investigate those drugs and modes of delivery that are most appropriate for them.

A further problem is the use of supplemental nitrous oxide/oxygen. This is often used in studies (particularly from North America) and would be expected to increase the overall level of sedation. Whilst there is nothing wrong in using supplemental nitrous oxide/oxygen it needs to be made clear from the outset that this is the case in clinical trials. Unfortunately it is often not mentioned initially when agents under test are described. For example the drug under investigation should be given as chloral hydrate and nitrous oxide/ oxygen rather than just chloral hydrate with a subsequent note buried in the text describing the use of supplemental nitrous oxide oxygen.

Finally the use of papoose boards needs to be clarified. What is the impact of physical restraint on sedative effectiveness? Or anxiety reduction? Further work needs to be done on the role of physical restraints in sedation of children. However, it is important that use of papoose board in a clinical trial of sedation should also be specified clearly from the outset.

\section{A CKN OWLEDGEMENTS}

The review authors would like to thank the two translators, Pati Pungchanchaikul and Jens Poppen. We also acknowledge the help and assistance of Cochrane Oral Health and the contribution of Susan Furness to all aspects of the 2012 update of this review, in particular data extraction, analysis and interpretation of data and entering data into Review Manager. We would like to thank Professor MT Hosey, King's College London, and Professor Richard Welbury, University of Central Lancashire, for their peer review comments. 


\section{R E F E R E N C E S}

\section{References to studies included in this review}

\section{Abrams 1993 \{published data only\}}

Abrams R, Morrison JE, Villasenor A, Hencmann D, Da Fonseca M, Mueller W. Safety and effectiveness of intranasal administration of sedative medications (ketamine, midazolam, or sufentanil) for urgent brief pediatric dental procedures. Anesthesia Progress 1993;40(3):63-6.

\section{Alfonzo-Echeverri 1993 \{published data only\}}

Alfonzo-Echeverri EC, Berg JH, Wild TW, Glass NL. Oral ketamine for pediatric outpatient dental surgery sedation. Pediatric Dentistry 1993;15(3):182-5.

\section{Al-Rakaf 2001 \{published data only\}}

Al-Rakaf H, Bello LL, Turkustani A, Adenubi JO. Intra-nasal midazolam in conscious sedation of young paediatric dental patients. International Journal of Paediatric Dentistry 2001;11(1):33-40.

\section{Avalos-Arenas 1998 \{published data only\}}

Avalos-Arenas V, Moyao-Garcia D, Nava-Ocampo AA, ZayasCarranza RE, Fragoso-Rios R. Is chloral hydrate/hydroxyzine a good option for paediatric dental outpatient sedation?. Current Medical Research and Opinion 1998;14(4):219-26.

\section{Averley 2004a \{published data only\}}

Averley PA, Lane I, Sykes J, Girdler NM, Steen N, Bond S. An RCT pilot study to test the effects of intravenous midazolam as a conscious sedation technique for anxious children requiring dental treatment - an alternative to general anaesthesia. British Dental Journal 2004;197(9):553-8.

\section{Averley 2004b \{published data only\}}

Averley PA, Girdler NM, Bond S, Steen N, Steele J. A randomised controlled trial of paediatric conscious sedation for dental treatment using intravenous midazolam combined with inhaled nitrous oxide or nitrous oxide/sevoflurane. Anaesthesia 2004;59(9):844-52.

\section{Aydintug 2004 \{published data only\}}

Aydintug YS, Okcu KM, Guner Y, Gunaydin Y, Sencimen M. Evaluation of oral or rectal midazolam as conscious sedation for pediatric patients in oral surgery. Military Medicine 2004;169(4):270-3.

\section{Baygin 2010 \{published data only\}}

Baygin O, Bodur H, Isik B. Effectiveness of premedication agents administered prior to nitrous oxide/oxygen. European Journal of Anaesthesiology 2010;27(4):341-6.

\section{Bhatnagar 2012 \{published data only\}}

Bhatnagar S, Das UM, Bhatnagar G. Comparison of oral midazolam with oral tramadol, triclofos and zolpidem in the sedation of pediatric dental patients: an in vivo study. Journal of the Indian Society of Pedodontics and Preventive Dentistry 2012;30(2):109-14.
Bui 2002 \{published data only\}

Bui T, Redden RJ, Murphy S. A comparison study between ketamine and ketamine-promethazine combination for oral sedation in pediatric dental patients. Anesthesia Progress 2002;49(1):14-8.

\section{Eshghi 2016 \{published data only\}}

Eshghi A, Mohammadpour M, Kaviani N, Tahririan D, Akhlaghi N. Comparative evaluation of bispectral index system after sedation with midazolam and propofol combined with remifentanil versus ketamine in uncooperative during dental procedures. Dental Research Journal 2016;13(1):1-6.

\section{Faytrouny 2007 \{published data only\}}

Faytrouny M, Okte Z, Kucukyavuz Z. Comparison of two different dosages of hydroxyzine for sedation in the paediatric dental patient. International Journal of Paediatric Dentistry 2007;17(5):378-82.

\section{Gallardo 1994 \{published data only\}}

Auil B, Cornejo G, Gallardo F. Flunitrazepam and diazepam compared as sedatives in children. ASDC Journal of Dentistry for Children 1983;50(6):442-4.

* Gallardo F, Cornejo G, Borie R. Oral midazolam as premedication for the apprehensive child before dental treatment. Journal of Clinical Pediatric Dentistry 1994;18(2):123-7.

Gomes 2017 \{published data only\}

Gomes HS, Gomes HS, Sado-Filho J, Costa LR, Costa PS. Does sevoflurane add to outpatient procedural sedation in children? A randomised clinical trial. BMC Pediatrics 2017;17(1):86.

Isik 2008a \{published data only\}

Isik B, Baygin O, Bodur H. Premedication with melatonin vs midazolam in anxious children. Pediatric Anesthesia 2008;18(7):635-41.

Isik 2008b \{published data only\} Isik B, Baygin O, Bodur H. Oral midazolam premedication in anxious children: effectiveness of different doses. Anestezi Dergisi 2008;16(1):34-40.

\section{Jensen 1999 \{published data only\}}

Jensen B, Schroder U, Mansson U. Rectal sedation with diazepam or midazolam during extractions of traumatized primary incisors: a prospective, randomized, double-blind trial in Swedish children aged 1.5-3.5 years. Acta Odontologica Scandinavica 1999;57(4):190-4.

\section{Kapur 2004 \{published data only\}}

Kapur A, Chawla HS, Goyal A, Gauba K, Bhardwaj N. Efficacy and acceptability of oral-transmucosal midazolam as a conscious sedation agent in pre-school children. Journal of the Indian Society of Pedodontics and Preventive Dentistry 2004;22(3):109-13. 
Kaviani 2015 \{published data only\}

Kaviani N, Ashrafi S, Jabbarifar SE, Ghaffari E. The efficacy of two intravenous sedative drugs in management of uncooperative children for dental treatments. Journal of Dentistry 2015;16(1 Suppl):29-34.

Koirala 2006 \{published data only\}

Koirala B, Pandey RK, Saksen AK, Kumar R, Sharma S. A comparative evaluation of newer sedatives in conscious sedation. Journal of Clinical Pediatric Dentistry 2006;30(4):273-6.

\section{Lahoud 2002 \{published data only\}}

Lahoud GY, Averley PA. Comparison of sevoflurane and nitrous oxide mixture with nitrous oxide alone for inhalation conscious sedation in children having dental treatment: a randomised controlled trial. Anaesthesia 2002;57(5):446-50.

\section{Lam 2005 \{published data only\}}

Lam C, Udin RD, Malamed SF, Good DL, Forrest JL. Midazolam premedication in children: a pilot study comparing intramuscular and intranasal administration. Anesthesia Progress 2005;52(2):56-61.

\section{Lee-Kim 2004 \{published data only\}}

Lee-Kim SJ, Fadavi S, Punwani I, Koerber A. Nasal versus oral midazolam sedation for pediatric dental patients. Journal of Dentistry for Children 2004;71(2):126-30.

\section{Malhotra 2016 \{published data only\}}

Malhotra PU, Thakur S, Singhal P, Chauhan D, Jayam C, Sood R, et al. Comparative evaluation of dexmedetomidine and midazolam-ketamine combination as sedative agents in pediatric dentistry: a double-blinded randomized controlled trial. Contemporary Clinical Dentistry 2016;7(2):186-92.

\section{McKee 1990 \{published data only\}}

McKee K, Nazif MM, Jackson DL, Barnhart DC, Close J, Moore PA. Dose-responsive characteristics of meperidine sedation in preschool children. Pediatric Dentistry 1990;12(4):222-7.

\section{Meyer 1990 \{published data only\}}

Meyer M, Mourino AP, Farrington FH. Comparison of triazolam to a chloral hydrate/hydroxyzine combination in the sedation of pediatric dental patients. Pediatric Dentistry 1990;12(5):283-7.

\section{Moody 1986 \{published data only\}}

Moody EH Jr, Mourino AP, Campbell RL. The therapeutic effectiveness of nitrous oxide and chloral hydrate administered orally, rectally, and combined with hydroxyzine for pediatric dentistry. ASDC Journal of Dentistry for Children 1986;53(6):425-9.

\section{Moore 1984 \{published data only\}}

Moore PA, Mickey EA, Hargreaves JA, Needleman HL. Sedation in pediatric dentistry: a practical assessment procedure. Journal of the American Dental Association 1984;109(4):564-9.

\section{Moreira 2013 \{published data only\}}

Moreira TA, Costa PS, Costa LR, Jesus-França CM, Antunes DE, Gomes HS, et al. Combined oral midazolam-ketamine better than midazolam alone for sedation of young children: a randomized controlled trial. International Journal of Paediatric Dentistry 2013;23(3):207-15.

\section{Mortazavi 2009 \{published data only\}}

Mortazavi M, Pourhashemi SJ, Khosravi MB, Ashtari S, Ghaderi F. Assessment of a low dose of IV midazolam used orally for conscious sedation in pediatric dentistry. Daru 2009;17(2):79-82.

Nathan 1988 \{published data only\}

Nathan JE, Venham LL, West MS, Werboff J. The effects of nitrous oxide on anxious young pediatric patients across sequential visits: a double-blind study. ASDC Journal of Dentistry for Children 1988;55(3):220-30.

\section{Özen 2012 \{published data only\}}

Özen B, Malamed SF, Cetiner S, Özalp N, Özer L, Altun C. Outcomes of moderate sedation in paediatric dental patients. Australian Dental Journal 2012;57(2):144-50.

\section{Park 2006 \{published data only\}}

Park M, Kim Y, Jung S, Beak K. Safety and efficacy of submucosal midazolam when combined with oral chloral hydrate, hydroxyzine and nitrous oxide sedation by using Houpt's scale. Journal of the Korean Dental Society of Anesthesiology 2006;6:103-12.

\section{Rai 2007 \{published data only\}}

Rai K, Hegde M, Goel K. Sedation in uncooperative children undergoing dental procedures: a comparative evaluation of midazolam, propofol and ketamine. Journal of Clinical Pediatric Dentistry 2007;32(1):1-4.

\section{Reeves 1996 \{published data only\}}

Reeves ST, Wiedenfeld KR, Wrobleski J, Hardin CL, Pinosky ML. A randomized double-blind trial of chloral hydrate/hydroxyzine versus midazolam/acetaminophen in the sedation of pediatric dental outpatients. ASDC Journal of Dentistry for Children 1996;63(2):95-100.

\section{Roelofse 1996a \{published data only\}}

Roelofse JA, Joubert JJ, Roelofse PG. A double-blind randomized comparison of midazolam alone and midazolam combined with ketamine for sedation of pediatric dental patients. Journal of Oral and Maxillofacial Surgery 1996;54(7):838-44.

Roelofse 1996b \{published data only\}

Roelofse JA, Joubert JJ, Swart LC, Stander I, Roelofse PG. An evaluation of the effect of oral ketamine and standard oral premedication in the sedation of paediatric dental patients. Journal of the Dental Association of South Africa 1996;51(4):197-201.

\section{Roelofse 1998 \{published data only\}}

Roelofse JA, Louw LR, Roelofse PG. A double-blind randomized comparison of oral trimeprazine-methadone and ketaminemidazolam for sedation of pediatric dental patients for oral surgical procedures. Anesthesia Progress 1998;45(1):3-11. 
Sams 1993a \{published data only\}

Sams DR, Cook EW, Jackson JG, Roebuck BL. Behavioral assessments of two drug combinations for oral sedation. Pediatric Dentistry 1993;15(3):186-90.

\section{Shanmugaavel 2016a \{published data only\}}

Shanmugaavel AK, Asokan S, Baby JJ, Priya G, Gnana Devi J. Comparison of behavior and dental anxiety during intranasal and sublingual midazolam sedation - A randomized controlled trial. Journal of Clinical Pediatric Dentistry 2016;40(1):81-7.

\section{Shanmugaavel 2016b $\{$ published data only\}}

Shanmugaavel AK, Asokan S, John JB, Priya PR, Raaja MT. Comparison of drug acceptance and anxiety between intranasal and sublingual midazolam sedation. Pediatric Dentistry 2016;38(2):106-11.

\section{Shashikiran 2006 \{published data only\}}

Shashikiran ND, Reddy SV, Yavagal CM. Conscious sedation - an artist's science! An Indian experience with midazolam. Journal of the Indian Society of Pedodontics and Preventive Dentistry 2006;24(1):7-14.

\section{Singh 2002 \{published data only\}}

Singh N, Pandey RK, Saksena AK, Jaiswal JN. A comparative evaluation of oral midazolam with other sedatives as premedication in pediatric dentistry. Journal of Clinical Pediatric Dentistry 2002;26(2):161-4.

\section{Singh 2014 \{published data only\}}

Singh C, Pandey RK, Saksena AK, Chandra G. A comparative evaluation of analgo-sedative effects of oral dexmedetomidine and ketamine: a triple-blind, randomized study. Pediatric Anesthesia 2014;24(12):1252-9.

\section{Somri 2012 \{published data only\}}

Somri M, Parisinos CA, Kharouba J, Cherni N, Smidt A, Abu Ras Z, et al. Optimising the dose of oral midazolam sedation for dental procedures in children: a prospective, randomised, and controlled study. International Journal of Paediatric Dentistry 2012;22(4):271-9.

\section{Surendar 2014 \{published data only\}}

Surendar MN, Pandey RK, Saksena AK, Kumar R, Chandra G. A comparative evaluation of intranasal dexmedetomidine, midazolam and ketamine for their sedative and analgesic properties: a triple blind randomized study. Journal of Clinical Paediatric Dentistry 2014;38(3):255-61.

\section{Torres-Perez 2007 \{published data only\}}

Torres-Perez J, Tapia-Garcia I, Rosales-Berber MA, HernandezSierra JF, Pozos-Guillen AJ. Comparison of three conscious sedation regimens for pediatric dental patients. Journal of Paediatric Dentistry 2007;31(2):183-6.

\section{Tyagi 2012 \{published data only\}}

Tyagi P, Dixit U, Tyagi S, Jain A. Sedative effects of oral midazolam, intravenous midazolam and oral diazepam. Journal of Clinical Pediatric Dentistry 2012;36(4):383-8.

\section{Veerkamp 1993 \{published data only\}}

Veerkamp JS, Gruythuysen RJ, Hoogstraten J, van Amerongen WE. Dental treatment of fearful children using nitrous oxide. Part 4: Anxiety after two years. ASDC Journal of Dentistry for Children 1993;60(4):372-6.

Veerkamp JS, Gruythuysen RJ, van Amerongen WE, Hoogstraten J. Dental treatment of fearful children using nitrous oxide. Part 2: The parents' point of view. ASDC Journal of Dentistry for Children 1992;59(2):115-9.

* Veerkamp JS, Gruythuysen RJ, van Amerongen WE, Hoogstraten J. Dental treatment of fearful children using nitrous oxide. Part 3: Anxiety during sequential visits. ASDC Journal of Dentistry for Children 1993;60(3):175-82.

Veerkamp JS, van Amerongen WE, Hoogstraten J, Groen HJ. Dental treatment of fearful children, using nitrous oxide. Part I: Treatment times. ASDC Journal of Dentistry for Children 1991;58(6):453-7.

\section{Wan 2006 \{published data only\}}

Wan $\mathrm{K}$, Jing $\mathrm{Q}$, Zhao JZ. Evaluation of oral midazolam as conscious sedation for pediatric patients in oral restoration. Chinese Medical Sciences Journal 2006;21(3):163-6.

\section{References to studies excluded from this review}

\section{Al-Zahrani 2009 \{published data only\}}

Al-Zahrani AM, Wyne AH, Sheta SA. Comparison of oral midazolam with a combination of oral midazolam and nitrous oxide-oxygen inhalation in the effectiveness of dental sedation for young children. Journal of the Indian Society of Pedodontics and Preventive Dentistry 2009;27(1):9-16.

Arya 2002 \{published data only\}

Arya VS, Damle SG. Comparative evaluation of midazolam and propofol as intravenous sedative agents in the management of unco-operative children. Journal of the Indian Society of Pedodontics and Preventive Dentistry 2002;20(1):6-8.

Badalaty 1990 \{published data only\}

Badalaty MM, Houpt MI, Koenigsberg SR, Maxwell KC, Desjardins PJ. A comparison of chloral hydrate and diazepam sedation in young children. Pediatric Dentistry 1990;12(1):33-7.

Baldinelli 1989 \{published data only\}

Baldinelli L, Melloti R. Outpatient intravenous sedation. Anesthesia Progress 1989;36(4-5):157-8.

Berge 1999 \{published data only\}

Berge TI. Acceptance and side effects of nitrous oxide oxygen sedation for oral surgical procedures. Acta Odontologica Scandinavica 1999;57(4):201-6.

Blake 1999 \{published and unpublished data\}

Blake K. A comparison of midazolam and propofol for dental sedation. National Research Register Document 1999. 


\section{Campbell 1998 \{published data only\}}

Campbell RL, Ross GA, Campbell JR, Mourino AP. Comparison of oral chloral hydrate with intramuscular ketamine, meperidine, and promethazine for pediatric sedation-preliminary report. Anesthesia Progress 1998;45(2):46-50.

\section{Canpolat 2017 \{published data only\}}

Canpolat DG, Yildirim MD, Kutuk N, Dogruel F, Ocak H, Aksu R, et al. Comparison of ketamine-propofol and ketaminedexmedetomidine combinations in children for sedation during tooth extraction. Journal of the Pakistan Medical Association 2017;67(5):693-7.

\section{Cathers 2005 \{published data only\}}

Cathers JW, Wilson CF, Webb MD, Alvarez ME, Schiffman T, Taylor S. A comparison of two meperidine/hydroxyzine sedation regimens for the uncooperative pediatric dental patient. Pediatric Dentistry 2005;27(5):395-400.

\section{Chaushu 2002 \{published data only\}}

Chaushu S, Gozal D, Becker A. Intravenous sedation: an adjunct to enable orthodontic treatment for children with disabilities. European Journal of Orthodontics 2002;24(1):81-9.

Coldwell 1999 \{published data only\}

Coldwell SE, Awamura KA, Milgrom P, Depner KS, Kaufman E, Preston KL, et al. Side effects of triazolam in children. Pediatric Dentistry 1999;21(1):18-25.

\section{da Costa 2007 \{published data only\}}

da Costa LR, da Costa PS, Lima AR. A randomized doubleblinded trial of chloral hydrate with or without hydroxyzine versus placebo for pediatric dental sedation. Brazilian Dental Journal 2007;18(4):334-40.

\section{Dallman 2001 \{published data only\}}

Dallman JA, Ignelzi MA Jr, Briskie DM. Comparing the safety, efficacy and recovery of intranasal midazolam vs oral chloral hydrate and promethazine. Pediatric Dentistry 2001;23(5):424-30.

\section{Davila 1990 \{published data only\}}

Davila JM. Restraint and sedation of the dental patient with developmental disabilities. Special Care Dentist 1990;10(6):210-2.

\section{Doring 1985 \{published data only\}}

Doring KR. Evaluation of an alphaprodine-hydroxyzine combination as a sedative agent in the treatment of the pediatric dental patient. Journal of the American Dental Association 1985;111(4):567-76.

\section{Downs 1997 \{published data only\}}

Downs AT, Dembo J, Ferretti G, Lyons TD, Pelphery A. A comparative study of midazolam to meperidine/promethazine as an IM sedative technique for the pediatric dental patient. ASDC Journal of Dentistry for Children 1997;64(3):197-200.
Duncan 1984 \{published data only\}

Duncan GH, Moore P. Nitrous oxide and the dental patient: a review of adverse reactions. Journal of the American Dental Association 1984;108(2):213-9.

Duncan 1994 \{published data only\}

Duncan WK, De Ball S, Perkins TM. Chloral hydrate sedation: a simple technique. Compendium 1994;15(7):884-7.

Dunn-Russell 1993 \{published data only\}

Dunn-Russell T, Adair SM, Sams DR, Russell CM, Barenie JT. Oxygen saturation and diffusion hypoxia in children following nitrous oxide sedation. Pediatric Dentistry 1993;15(2):88-92.

el Magboul 1995 \{published data only\}

el Magboul KM, O'Sullivan EA, Curzon ME. A clinical trial comparing two doses of oral temazepam for sedation of paediatric dental patients. International Journal of Paediatric Dentistry 1995;5(2):97-102.

\section{Erlandsson 2001 \{published data only\}}

Erlandsson AL, Backman B, Stenstrom A, Stecksen-Blicks C. Conscious sedation by oral administration of midazolam in paediatric dental treatment. Swedish Dental Journal 2001;25(3):97-104.

\section{Evans 1966 \{published data only\}}

Evans WO, Tannenbaum K, Turek B, Ailing EF. A method for evaluating the use of premedicating agents in difficult pedodontic patients. ASDC Journal of Dentistry for Children 1966;33:317-23.

\section{Flaitz 1985 \{published data only\}}

Flaitz CM, Novak AJ. Evaluation of the sedative effect of rectally administered diazepam for the young dental patient. Pediatric Dentistry 1985;7(4):292-6.

Flaitz CM, Nowak AJ, Hicks MJ. Double-blind comparison of rectally administered diazepam to placebo for pediatric sedation: the cardiovascular response. Anesthesia Progress 1985;32(6):232-6.

\section{Fuks 1994 \{published data only\}}

Fuks AB, Kaufman E, Ram D, Hovav S, Shapira J. Assessment of two doses of intranasal midazolam for sedation of young pediatric dental patients. Pediatric Dentistry 1994;16(4):301-5.

\section{Fukuta 1993 \{published data only\}}

Fukuta O, Braham RL, Yanase H, Atsumi N, Kurosu K. The sedative effect of intranasal midazolam administration in the dental treatment of patients with mental disabilities. Part 1: the effect of a $0.2 \mathrm{mg} / \mathrm{kg}$ dose. Journal of Clinical Pediatric Dentistry 1993;17(4):231-7.

\section{Fukuta 1994 \{published data only\}}

Fukuta O, Braham RL, Yanase H, Kurosu K. The sedative effects of intranasal midazolam administration in the dental treatment of patients with mental disabilities. Part 2: optimal concentration of intranasal midazolam. Journal of Clinical Pediatric Dentistry 1994;18(4):259-65. 
Gallardo 1984 \{published data only\}

Gallardo F, Cornejo G, Auil B. Premedication with flunitrazepam, diazepam and placebo in the apprehensive child. ASDC Journal of Dentistry for Children 1984;51(3):208-10.

\section{Gamonal Aravena 1989 \{published data only\}}

Gamonal Aravena J. Effectiveness of chlormezanone and flunitrazepam in treatment of difficult children. Revista Dental de Chile 1989;80(2):64-9.

\section{Garton 1970 \{published data only\}}

Garton J. Intravenous sedation in dental practice. Dental Student 1970;48(9):66-7.

\section{Haas 1996 \{published data only\}}

Haas DA, Nenninger SA, Yacobi R, Magathan JG, Grad HA, Copp PE, et al. A pilot study of the efficacy of oral midazolam for sedation in pediatric dental patients. Anesthesia Progress 1996;43(1):1-8.

\section{Hall 2006 \{published data only\}}

Hall DL, Tatakis DN, Walters JD, Rezvan E. Oral clonidine pretreatment and diazepam/meperidine sedation. Journal of Dental Research 2006;85(9):854-8.

\section{Hartgraves 1994 \{published data only\}}

Hartgraves PM, Primosch RE. An evaluation of oral and nasal midazolam for pediatric dental sedation. ASDC Journal of Dentistry for Children 1994;61(3):175-81.

\section{Hasty 1991 \{published data only\}}

Hasty MF, Vann WF Jr, Dilley DC, Anderson JA. Conscious sedation of pediatric dental patients: an investigation of chloral hydrate, hydroxyzine pamoate, and meperidine vs chloral hydrate and hydroxyzine pamoate. Pediatric Dentistry 1991;13(1):10-9.

\section{Heard 2010 \{published data only\}}

Heard C, Smith J, Creighton P, Joshi P, Feldman D, Lerman J. A comparison of four sedation techniques for pediatric dental surgery. Pediatric Anesthesia 2010;20(10):924-30.

\section{Henry 1990 \{published data only\}}

Henry RJ, Jerrell RG. Ambient nitrous oxide levels during pediatric sedations. Pediatric Dentistry 1990;12(20):87-91.

\section{Houpt 1985a \{published data only\}}

Houpt MI, Weiss NJ, Koenigsberg SR, Desjardins PJ. Comparison of chloral hydrate with and without promethazine in the sedation of young children. Pediatric Dentistry 1985;7(1):41-6.

\section{Houpt 1985b \{published data only\}}

Houpt MI, Sheskin RB, Koenigsberg SR, Desjardins PJ, Shey Z. Assessing chloral hydrate dosage for young children. ASDC Journal of Dentistry for Children 1985;52(5):364-9.

\section{Houpt 1989 \{published data only\}}

Houpt M, Manetas C, Joshi A, Desjardins P. Effects of chloral hydrate on nitrous oxide sedation of children. Pediatric Dentistry 1989;11(1):26-9.
Houpt 1996 \{published data only\}

Houpt MI, Kupietzky A, Tofsky NS, Koenigsberg SR. Effects of nitrous oxide on diazepam sedation of young children. Pediatric Dentistry 1996;18(3):236-41.

\section{Hulland 2002 \{published data only\}}

Hulland SA, Freilich MM, Sandor GK. Nitrous oxide-oxygen or oral midazolam for pediatric outpatient sedation. Oral Surgery, Oral Medicine, Oral Pathology, Oral Radiology, and Endodontics 2002;93(6):643-6.

\section{Isik 2008 \{published data only\}}

Isik B, Baygin O, Bodur H. Effect of drinks that are added as flavouring in oral midazolam premedication on sedation success. Pediatric Anesthesia 2008;18(6):494-500.

\section{Jensen 1998 \{published data only\}}

Jensen B, Schroder U. Acceptance of dental care following early extractions under rectal sedation with diazepam in preschool children. Acta Odontologica Scandinavica 1998;56(4):229-32.

\section{Kantovitz 2007 \{published data only\}}

Kantovitz KR, Puppin-Rontani RM, Gaviao MB. Sedative effect of oral diazepam and chloral hydrate in the dental treatment of children. Journal of the Indian Society of Pedodontics and Preventive Dentistry 2007;25(2):69-75.

\section{Kayalibay 1987 \{published data only\}}

Kayalibay $\mathrm{H}$. The use of chloral hydrate for enteral sedation in adaptation of patients in pedodontics. Dent, Contemporary Dentistry 1987;2(1):20-5

Kerins 2007 \{published data only\} Kerins CA, McWhorter AG, Seale NS. Pharmacologic behavior management of pediatric dental patients diagnosed with attention deficit disorder/attention deficit hyperactivity disorder. Pediatric Dentistry 2007;29(6):507-13.

Kopel 1971 \{published data only\}

Kopel HM. Hydroxyzine as a pre-operative sedative: a doubleblind study with apprehensive children. Anesthesia Progress 1971;18(6):127-33.

\section{Koroluk 2000 \{published data only\}}

Koroluk LD. Dental anxiety in adolescents with a history of childhood dental sedation. ASDC Journal of Dentistry for Children 2000;67(3):200-5.

\section{Kramer 1991a \{published data only\}}

Kramer N, Krafft T, Kunzelmann KH, Hickel R. Individually controlled sedation using midazolam. Deutsche Zahnarzthiche Zeitschrift 1991;46(2):142-4.

\section{Kramer 1991b \{published data only\}}

Kramer N, Krafft T, Hunzelmann KH, Hickel R. Sedation under rectal application of midazolam. Deutsche Zahnarzthiche Zeitschrift 1991;46(9):609-11. 
Kupietzky 1996 \{published data only\}

Kupietzky A, Holan G, Shapira J. Intranasal midazolam better at effecting amnesia after sedation than oral hydroxyzine: a pilot study. Pediatric Dentistry 1996;18(1):32-4.

\section{Lahoud 2001 \{published data only\}}

Lahoud GY, Averley PA, Hanlon MR. Sevoflurane inhalation conscious sedation for children having dental treatment. Anaesthesia 2001;56(5):476-80.

\section{Leelataweedwud 2001 \{published data only\}}

Leelataweedwud P, Vann WF Jr. Adverse events and outcomes of conscious sedation for pediatric patients: study of an oral sedation regimen. Journal of the American Dental Association 2001;132(11):1531-9.

\section{Leelataweewud 2000 \{published data only\}}

Leelataweewud P, Vann WF Jr, Dilley DC, Lucas WJ. The physiological effects of supplemental oxygen versus nitrous oxide/oxygen during conscious sedation of pediatric dental patients. Pediatric Dentistry 2000;22(2):125-33.

\section{Lima 2003 \{published data only\}}

Lima AR, da Costa LR, da Costa PS. A randomized, controlled, cross-over trial of oral midazolam and hydroxyzine for pediatric dental sedation. Pesquisa Odontologica Brasileira 2003;17(3):206-11.

\section{Lindh-Stromberg 2001 \{published data only\}}

Lindh-Stromberg U. Rectal administration of midazolam for conscious sedation of uncooperative children in need of dental treatment. Swedish Dental Journal 2001;25(3):105-11.

\section{Lindsay 1980 \{published data only\}}

Lindsay SJ, Roberts GJ. Methods for behaviour research on dentally anxious children. The example of relative analgesia. British Dental Journal 1980;149(6):175-9.

\section{Lindsay 1985 \{published data only\}}

Lindsay SJ, Yates JA. The effectiveness of oral diazepam in anxious child dental patients. British Dental Journal 1985;159(5):149-53.

\section{Litman 1997 \{published data only\}}

Litman RS, Kottra JA, Berkowitz RJ, Ward DS. Breathing patterns and levels of consciousness in children during administration of nitrous oxide or after midazolam premedication. Journal of Oral and Maxillofacial Surgery 1997;55(12):1372-7.

\section{Litman 1998 \{published data only\}}

Litman RS, Kottra JA, Verga KA, Berkowitz RJ, Ward DS. Chloral hydrate sedation: the additive sedative and respiratory depressant effects of nitrous oxide. Anesthesia and Analgesia 1998;86(4):724-8.

\section{Lökken 1994 \{published data only\}}

Lökken P, Bakstad OJ, Fonnelop E, Skogedal N, Hellsten K, Bjerkelund $\mathrm{CE}$, et al. Conscious sedation by rectal administration of midazolam or midazolam plus ketamine as alternatives to general anesthesia for dental treatment of uncooperative children. Scandinavian Journal of Dental Research 1994;102(5):274-80.

Machen 1977 \{published data only\}

Machen JB, Ayer WA, Mueller BH. Psychomotor effects of nitrous oxide-oxygen sedation on children. ASDC Journal of Dentistry for Children 1977;44(3):219-21.

\section{Malamed 1989 \{published data only\}}

Malamed SF, Quinn CL, Hatch HG. Pediatric sedation with intramuscular and intravenous midazolam. Anesthesia Progress 1989;36(4-5):155-7.

\section{Marshall 1999 \{published data only\}}

Marshall WR, Weaver BD, McCutcheon P. A study of the effectiveness of oral midazolam as a dental preoperative sedative and hypnotic. Special Care in Dentistry 1999;19(6):259-66.

\section{Martinez 2006 \{published data only\}}

Martinez D, Wilson S. Children sedated for dental care: a pilot study of the 24-hour postsedation period. Pediatric Dentistry 2006;28(3):260-4.

\section{McCann 1996 \{published data only\}}

McCann W, Wilson S, Larsen P, Stehle B. The effects of nitrous oxide on behavior and physiological parameters during conscious sedation with a moderate dose of chloral hydrate and hydroxyzine. Pediatric Dentistry 1996;18(1):35-41.

Milnes 2000 \{published data only\}

Milnes AR, Maupome G, Cannon J. Intravenous sedation in pediatric dentistry using midazolam, nalbuphine and droperidol. Pediatric Dentistry 2000;22(2):113-9.

\section{Moore 1997 \{published data only\}}

Moore PA, Finder RL, Jackson DL. Multidrug intravenous sedation: determinants of the sedative dose of midazolam. Oral Surgery, Oral Medicine, Oral Pathology, Oral Radiology, and Endodontics 1997;84(1):5-10.

Musial 2003 \{published data only\}

Musial KM, Wilson S, Preisch J, Weaver J. Comparison of the efficacy of oral midazolam alone versus midazolam and meperidine in the pediatric dental patient. Pediatric Dentistry 2003;25(5):468-74.

\section{Myers 1977 \{published data only\}}

Myers M, Shoaf HK. The intramuscular use of a combination of meperidine, promethazine and chlorpromazine for sedation of the child dental patient. ASDC Journal of Dentistry for Children 1977;44(6):453-6.

\section{Myers 2004 \{published data only\}}

Myers GR, Maestrello CL, Mourino AP, Best AM. Effect of submucosal midazolam on behaviour and physiologic response when combined with oral chloral hydrate and nitrous oxide sedation. Pediatric Dentistry 2004;26(1):37-43. 
Nathan 1987 \{published data only\}

Nathan JE, West MS. Comparison of chloral hydratehydroxyzine with and without meperidine for management of the difficult pediatric patient. ASDC Journal of Dentistry for Children 1987;54(6):437-44.

Oei-Lim 1991 \{published data only\}

Oei-Lim LB, Vermeulen-Cranch DM, Bouvy-Berends EC. Conscious sedation with propofol in dentistry. British Dental Journal 1991;170(9):340-2.

\section{Pandey 2010 \{published data only\}}

Pandey RK, Padmanabhan MY, Saksena AK, Chandra G. Midazolam-fentanyl analgo-sedation in pediatric dental patients - a pilot study. Journal of Clinical Pediatric Dentistry 2010;35(1):105-10

\section{Pisalchaiyong 2005 \{published data only\}}

Pisalchaiyong T, Trairatvorakul C, Jirakijja J, Yuktarnonda W. Comparison of the effectiveness of oral diazepam and midazolam for the sedation of autistic patients during dental treatment. Pediatric Dentistry 2005;27(3):198-206.

\section{Poorman 1990 \{published data only\}}

Poorman TL, Farrington FH, Mourino AP. Comparison of a chloral hydrate/hydroxyzine combination with and without meperidine in the sedation of pediatric dental patients. Pediatric Dentistry 1990;12(5):288-91.

\section{Primosch 1999 \{published data only\}}

* Primosch RE, Buzzi IM, Jerrell G. Effect of nitrous oxideoxygen inhalation with scavenging on behavioral and physiological parameters during routine pediatric dental treatment. Pediatric Dentistry 1999;21(7):417-20.

Primosch RE, Buzzi IM, Jerrell G. Monitoring pediatric dental patients with nasal mask capnography. Pediatric Dentistry 2000;22(2):120-4.

\section{Primosch 2001 \{published data only\}}

Primosch RE, Bender F. Factors associated with administration route when using midazolam for pediatric conscious sedation. ASDC Journal of Dentistry for Children 2001;68(4):233-8.

\section{Quarnstrom 1992 \{published data only\}}

Quarnstrom FC, Milgrom P, Moore PA. Experience with triazolam in preschool children. Anesthesia and Pain Control in Dentistry 1992;1(3):157-9.

\section{Ram 1999 \{published data only\}}

Ram D, Mamber E, Chosack A, Fuks AB. The effect of metoclopramide and hydroxyzine in sedation of infants undergoing dental treatment. ASDC Journal of Dentistry for Children 1999;66(1):49-52.

\section{Reinemer 1996 \{published data only\}}

Reinemer HC, Wilson CF, Webb M. A comparison of two oral ketamine-diazepam regimens for sedating anxious pediatric dental patients. Pediatric Dentistry 1996;18(4):294-300.
Robbins 1967 \{published data only\}

Robbins MB. Chloral hydrate and promethazine as premedicants for the apprehensive child. Journal of Dentistry for Children 1967;34(5):327-31.

\section{Roberts 1979 \{published data only\}}

Roberts GJ, Gibson A, Porter J, de Zoysa S. Relative analgesia. An evaluation of the efficacy and safety. British Dental Journal 1979;146(6):177-82.

\section{Roberts 1982 \{published data only\}}

Roberts GJ, Wignall BK. Efficacy of the laryngeal reflex during oxygen-nitrous oxide sedation (relative analgesia). British Journal of Anaesthesia 1982;54(12):1277-81.

Roberts 1992 \{published data only\}

Roberts SM, Wilson CF, Seale NS, McWhorter AG. Evaluation of morphine as compared to meperidine when administered to the moderately anxious pediatric dental patient. Pediatric Dentistry 1992;14(5):306-13.

\section{Robertson 1998 \{published data only\}}

Robertson HG. A Comparison Between Nitrous Oxide and Oral Midazolam for Sedation in Paediatric Dentistry [Diploma in Conscious Sedation]. Newcastle upon Tyne (UK): University of Newcastle upon Tyne 1998.

Roelofse 1990 \{published data only\}

Roelofse JA, van der Bijl P, Stegmann DH, Hartshorne JE. Preanesthetic medication with rectal midazolam in children undergoing dental extractions. Journal of Oral and Maxillofacial Surgery 1990;48(8):791-6.

Roelofse 1993 \{published data only\}

Roelofse JA, van der Bijl P. Comparison of rectal midazolam and diazepam for premedication in pediatric dental patients. Journal of Oral and Maxillofacial Surgery 1993;51(5):525-9.

Rohlfing 1998 \{published data only\}

Rohlfing GK, Dilley DC, Lucas WJ, Vann WF Jr. The effect of supplemental oxygen on apnea and oxygen saturation during pediatric conscious sedation. Pediatric Dentistry 1998;20(8):8-16.

\section{Sams 1992 \{published data only\}}

Sams DR, Thornton JB, Wright JT. The assessment of two ora sedation drug regimens in pediatric dental patients. $A S D C$ Journal of Dentistry for Children 1992;59(4):306-12.

\section{Sams 1993b \{published data only\}}

Sams DR, Russell CM. Physiologic response and adverse reactions in pediatric dental patients sedated with promethazine and chloral hydrate or meperidine. Pediatric Dentistry 1993;15(6):422-4.

\section{Sanders 1997 \{published data only\}}

Sanders BJ, Avery DR. The effect of sleep on conscious sedation: a follow-up study. Journal of Clinical Pediatric Dentistry 1997;21(2):131-4. 
Shapira 1992 \{published data only\}

Shapira J, Holan G, Guelmann M, Cahan S. Evaluation of the effect of nitrous oxide and hydroxyzine in controlling the behavior of the pediatric dental patient. Pediatric Dentistry 1992;14(3):167-70.

\section{Shapira 1996 \{published data only\}}

Shapira J, Holan G, Botzer E, Kupietzky A, Tal E, Fuks AB. The effectiveness of midazolam and hydroxyzine as sedative agents for young pediatric dental patients. ASDC Journal of Dentistry for Children 1996;63(6):421-5.

\section{Shapira 2004 \{published data only\}}

Shapira J, Kupietzky A, Kadari A, Fuks AB, Holan G. Comparison of oral midazolam with and without hydroxyzine in the sedation of pediatric dental patients. Pediatric Dentistry 2004;26(6):492-6.

\section{Sharma 1992 \{published data only\}}

Sharma RK, Pinto RR, Mirchandani NN. Use of sedation analgesia for pediatric dentistry. Journal of the Indian Society of Pedodontics and Preventive Dentistry 1992;10(1):28-32.

\section{Sheroan 2006 \{published data only\}}

Sheroan MM, Dilley DC, Lucas WJ, Vann WF. A prospective study of 2 sedation regimens in children: chloral hydrate, meperidine, and hydroxyzine versus midazolam, meperidine, and hydroxyzine. Anesthesia Progress 2006;53(4):83-90.

\section{Silver 1994 \{published data only\}}

Silver T, Wilson C, Webb M. Evaluation of two dosages of oral midazolam as a conscious sedation for physically and neurologically compromised pediatric dental patients. Pediatric Dentistry 1994;16(5):350-9.

\section{Songvasin 1990 \{published data only\}}

Songvasin C, Pasavorakul A. A comparison of the child's behavior between two groups of oral sedative drugs. Journal of the Dental Association of Thailand 1990;40(6):237-45.

\section{Subramaniam 2017 \{published data only\}}

Subramaniam P, Girish Babu KL, Lakhotia D. Evaluation of nitrous oxide-oxygen and triclofos sodium as conscious sedative agents. Journal of the Indian Society of Pedodontics and Preventive Dentistry 2017;35(2):156-161.

\section{Sullivan 2001 \{published data only\}}

Sullivan DC, Wilson CF, Webb MD. A comparison of two oral ketamine-diazepam regimens for the sedation of anxious pediatric dental patients. Pediatric Dentistry 2001;23(3):223-31.

\section{Tanaka 2000 \{published data only\}}

Tanaka M, Sato M, Saito A, Nishikawa T. Reevaluation of rectal ketamine premedication in children: comparison with rectal midazolam. Anaesthesiology 2000;93(5):1217-24.

\section{Tobias 1975 \{published data only\}}

Tobias M, Lipschultz DH, Album MM. A study of three preoperative sedative combinations. ASDC Journal of Dentistry for Children 1975;42(6):453-9.

\section{Tsinidou 1992 \{published data only\}}

Tsinidou KG, Curzon ME, Sapsford DJ. A study to compare the effectiveness of temazepam and a chloral hydrate/ hydroxyzine combination in sedating paediatric dental patients. International Journal of Paediatric Dentistry 1992;2(3):163-9.

\section{van der Bijl 1991 \{published data only\}}

van der Bijl P, Roelofse JA, Joubert JJ, van Zyl JF. Comparison of various physiologic and psychomotor parameters in patients sedated with intravenous lorazepam, diazepam, or midazolam during oral surgery. Journal of Oral and Maxillofacial Surgery 1991;49(7):672-8.

\section{Varpio 1991 \{published data only\}}

Varpio M, Wellfelt B. Some characteristics of children with dental behaviour problems. Five-year follow-up pedodontic treatment. Swedish Dental Journal 1991;15(2):83-93.

\section{Veerkamp 1997 \{published data only\}}

Veerkamp JSJ, Porcelijn T, Gruythuysen RJ. Intravenous sedation for outpatient treatment of child dental patients: an exploratory study. ASDC Journal of Dentistry for Children 1997;64(1):48-54.

\section{Whitehead 1988 \{published data only\}}

Whitehead BG, Durr DP, Adair SM, Proskin HM. Monitoring of sedated pediatric dental patients. ASDC Journal of Dentistry for Children 1988;55(5):329-33.

\section{Wilson 1990 \{published data only\}}

Wilson S. Conscious sedation and pulse oximetry: false alarms?. Pediatric Dentistry 1990;12(4):228-32.

\section{Wilson 1992 \{published data only\}}

Wilson S. Chloral hydrate and its effects on multiple physiological parameters in young children: a dose-response study. Pediatric Dentistry 1992;14(3):171-7.

Wilson 1993 \{published data only\}

Wilson S. Facial electromyography and chloral hydrate in the young dental patient. Pediatric Dentistry 1993;15(5):343-7.

\section{Wilson 2000 \{published data only\}}

Wilson S, Easton J, Lamb K, Orchardson R, Casamassimo P. A retrospective study of chloral hydrate, meperidine, hydroxyzine, and midazolam regimens used to sedate children for dental care. Pediatric Dentistry 2000;22(2):107-12.

\section{Wilson 2002 \{published data only\}}

* Wilson KE, Welbury RR, Girdler NM. A randomised, controlled, cross-over trial of oral midazolam and nitrous oxide for paediatric dental sedation. Anaesthesia 2002;57(9):860-7.

Wilson KE, Welbury RR, Girdler NM. A study of the effectiveness of oral midazolam sedation for orthodontic extraction of permanent teeth in children: a prospective, randomised, controlled, cross-over trial. British Dental Journal 2002;192(8):457-62. 
Wilson 2003 \{published data only\}

Wilson KE, Girdler NM, Welbury RR. Randomized, controlled, cross-over clinical trial comparing intravenous midazolam sedation with nitrous oxide sedation in children undergoing dental extractions. British Journal of Anaesthesia 2003;91(6):850-6.

\section{Wilson 2006 \{published data only\}}

Wilson KE, Girdler NM, Welbury RR. A comparison of oral midazolam and nitrous oxide sedation for dental extractions in children. Anaesthesia 2006;61(12):1138-44.

\section{Wilson 2007 \{published data only\}}

Wilson KE, Welbury RR, Girdler NM. Comparison of transmucosal midazolam with inhalation sedation for dental extractions in children. A randomized, cross-over, clinical trial. Acta Anaesthesiologica Scandinavica 2007;51(8):1062-7.

\section{Yanase 1996 \{published data only\}}

Yanase H, Braham RL, Fukuta O, Kurosu K. A study of the sedative effect of home-administered oral diazepam for the dental treatment of children. International Journal of Paediatric Dentistry 1996;6(1):13-7.

\section{Additional references}

\section{AAP 1992}

American Academy of Pediatrics Committee on Drugs. American Academy of Pediatrics Committee on Drugs: Guidelines for monitoring and management of pediatric patients during and after sedation for diagnostic and therapeutic procedures. Pediatrics 1992;89(6 Pt 1):1110-5.

\section{Egger 1997}

Egger M, Davey Smith G, Schneider M, Minder C. Bias in meta-analysis detected by a simple, graphical test. BMJ 1997;315(7109):629-34.

\section{GRADE 2004}

Atkins D, Best D, Briss PA, Eccles M, Falck-Ytter Y, Flottorp S, et al. Grading quality of evidence and strength of recommendations. BMJ 2004;328(7454):1490.

\section{Higgins 2011}

Higgins JP, Green S, editor(s). Cochrane Handbook for Systematic Reviews of Interventions Version 5.1.0 (updated March 2011). The Cochrane Collaboration, 2011. Available from handbook.cochrane.org.

\section{Klingberg 1994}

Klingberg G, Vannas Lofqvist L, Bjarnason S, Noren JG. Dental behaviour management problems in Swedish children. Community Dentistry and Oral Epidemiology 1994;22(3):201-5.

\section{Klingberg 1995}

Klingberg G, Berggren U, Carlsson SG, Noren JG. Child dental fear: cause-related factors and clinical effects. European Journal of Oral Science 1995;103(6):405-12.

\section{Lefebvre 2011}

Lefebvre C, Manheimer E, Glanville J. Chapter 6: Searching for studies. In: Higgins JP, Green S, editor(s). Cochrane Handbook for Systematic Reviews of Interventions Version 5.1.0 (updated March 2011). The Cochrane Collaboration, 2011. Available from handbook.cochrane.org.

\section{Moher 2001}

Moher D, Schulz KF, Altman DG. The CONSORT statement: revised recommendations for improving the quality of reports of parallel-group randomised trials. Lancet 2001;357(9263):1191-4.

\section{NDEP 2015}

Public Health England, National Dental Epidemiology Programme for England. National Dental Epidemiology Programme for England: oral health survey of five-year-old children 2015. A report on the prevalence and severity of dental decay.www.nwph.net/dentalhealth/14_15_5yearold/14_15_16/ DPHEP\%20for\%20England\%200H\%20Survey\%205yr \%202015\%20Report\%20FINAL\%20Gateway\%20approved.pdf (accessed 15 May 2016).

\section{NICE 2010}

National Institute for Health and Care Excellence (NICE). Sedation for diagnostic and therapeutic procedures in children and young people. Clinical Guideline CG112. Available from www.nice.org.uk/guidance/cg112 2010.

\section{Review Manager 2014 [Computer program]}

Nordic Cochrane Centre, The Cochrane Collaboration. Review Manager 5 (RevMan 5). Version 5.3. Copenhagen: Nordic Cochrane Centre, The Cochrane Collaboration, 2014.

\section{Veerkamp 1995}

Veerkamp JS, Gruythuysen RJM, Hoogstraten J, van Amerongen WE. Anxiety reduction with nitrous oxide: a permanent solution. Journal of Dentistry for Children 1995;62(1):44-8.

\section{WHO 2012}

World Health Organization (WHO). Oral Health Factsheet 3018, April 2012. www.who.int/mediacentre/factsheets/fs318/en/ index.htm (accessed 20 March 2016).

\section{References to other published versions of this review}

\section{Matharu 2002}

Matharu L, Ashley P. Sedation of anxious children undergoing dental treatment. Cochrane Database of Systematic Reviews 2002, Issue 3. [DOI: 10.1002/14651858.CD003877]

\section{Matharu 2005}

Matharu LM, Ashley PF. Sedation of anxious children undergoing dental treatment. Cochrane Database of Systematic Reviews 2005, Issue 2. [DOI: 10.1002/14651858.CD003877.pub2] 


\section{Matharu 2006}

Matharu L, Ashley PF. Sedation of anxious children undergoing dental treatment. Cochrane Database of Systematic Reviews 2006, Issue 1. [DOI: 10.1002/14651858.CD003877.pub3]

\section{Matharu 2012}

Lourenço-Matharu L, Ashley PF, Furness S. Sedation of children undergoing dental treatment. Cochrane Database of Systematic Reviews 2012, Issue 3. [DOI: 10.1002/14651858.CD003877.pub4]

* Indicates the major publication for the study

\title{
CHARACTERISTICS OF STUDIES
}

Characteristics of included studies [ordered by study ID]

\begin{abstract}
Abrams 1993
\end{abstract}

\begin{tabular}{|c|c|c|}
\hline Methods & \multicolumn{2}{|c|}{$\begin{array}{l}\text { Parallel design, pilot study } \\
\text { Funding: grant from Children's Hospital Research Institute } \\
\text { Location: USA }\end{array}$} \\
\hline Participants & \multicolumn{2}{|c|}{$\begin{array}{l}\text { Inclusion criteria: children whose "unruly or hysterical behavior precluded adequate examination or } \\
\text { treatment" } \\
n=30 \text { ( } 10 \text { per group with sufentanil divided into } 2 \text { subgroups of } 5 \text { each) } \\
\text { Age range }=17 \text { to } 62 \text { months }\end{array}$} \\
\hline Interventions & \multicolumn{2}{|c|}{$\begin{array}{l}\text { Group } 1(n=10): \text { ketamine }(3 \mathrm{mg} / \mathrm{kg}) \\
\text { Group } 2(n=10): \text { midazolam }(0.4 \mathrm{mg} / \mathrm{kg}) \\
\text { Group } 3(n=5): \text { sufentanil }(1 \mu \mathrm{g} / \mathrm{kg}) \\
\text { Group } 4(n=5): \text { sufentanil }(1.5 \mu \mathrm{kg}) \\
\text { All intranasal, administered by paediatric anaesthesiologist or dentist }\end{array}$} \\
\hline Outcomes & \multicolumn{2}{|c|}{ Sedation scoring criteria, recovery time } \\
\hline Notes & \multicolumn{2}{|c|}{ Sufentanil $1.5 \mu \mathrm{g} / \mathrm{kg}$ and ketamine caused significant desaturations as recorded by pulse oximeter } \\
\hline \multicolumn{3}{|l|}{ Risk of bias } \\
\hline Bias & Authors' judgement & Support for judgement \\
\hline $\begin{array}{l}\text { Random sequence genera- } \\
\text { tion (selection bias) }\end{array}$ & Unclear risk & "Selected at random" - method of sequence generation not described \\
\hline $\begin{array}{l}\text { Allocation concealment } \\
\text { (selection bias) }\end{array}$ & Unclear risk & Not described \\
\hline Blinding - Participant & Low risk & Study described as double-blind \\
\hline $\begin{array}{l}\text { Blinding - Operator/seda- } \\
\text { tionist }\end{array}$ & Unclear risk & It seems likely that operating dentist was blinded \\
\hline $\begin{array}{l}\text { Blinding - Outcome asses- } \\
\text { sor }\end{array}$ & High risk & $\begin{array}{l}\text { Study described as double-blind, but "significant desaturations observed early } \\
\text { in the study resulted in breaking the code" }\end{array}$ \\
\hline $\begin{array}{l}\text { Incomplete outcome as- } \\
\text { sessment }\end{array}$ & Low risk & All patients included in outcome evaluation \\
\hline Free of selective reporting & Low risk & All planned outcomes reported \\
\hline Free of other bias & Unclear risk & $\begin{array}{l}\text { Following significant desaturations and prolonged recovery time the dose of } \\
\text { sufentanil was reduced to } 1.0 \mathrm{\mu g} / \mathrm{kg} \text { during the trial }\end{array}$ \\
\hline
\end{tabular}


Al-Rakaf 2001

\begin{tabular}{|c|c|}
\hline Methods & $\begin{array}{l}\text { Parallel design RCT } \\
\text { Funded by College of Dentistry Research Centre, King Saud University, Riyadh } \\
\text { Location: Saudi Arabia }\end{array}$ \\
\hline Participants & $\begin{array}{l}\text { Unco-operative ("Frankl behavior score } 1 \text { or } 2 " \text { ) } \\
n=38 \text { children } \\
\text { Mean age }(S D) \text { in years and gender: } \\
\text { Group } 1(n=12), 3.75(0.75), 6 \text { male, } 6 \text { female } \\
\text { Group } 2(n=13), 4.3(0.65), 6 \text { male, } 7 \text { female } \\
\text { Group } 3(n=13), 4(0.71), 6 \text { male, } 7 \text { female }\end{array}$ \\
\hline Interventions & $\begin{array}{l}\text { Group 1: midazolam }(0.3 \mathrm{mg} / \mathrm{kg}) \\
\text { Group 2: midazolam }(0.4 \mathrm{mg} / \mathrm{kg}) \\
\text { Group 3: midazolam }(0.5 \mathrm{mg} / \mathrm{kg}) \\
\text { All intranasal }\end{array}$ \\
\hline Outcomes & Houpt \\
\hline Notes & $\begin{array}{l}\text { Papoose board. Groups subdivided into fasting and non-fasting } \\
\text { Error in Table } 1 \text { on page } 36 \text { where } 49 \text { was written instead of } 4.9\end{array}$ \\
\hline
\end{tabular}

\section{Risk of bias}

\begin{tabular}{|c|c|c|}
\hline Bias & Authors' judgement & Support for judgement \\
\hline $\begin{array}{l}\text { Random sequence genera- } \\
\text { tion (selection bias) }\end{array}$ & Unclear risk & "Randomly assigned" - method of sequence generation not described \\
\hline $\begin{array}{l}\text { Allocation concealment } \\
\text { (selection bias) }\end{array}$ & Unclear risk & Not described \\
\hline Blinding - Participant & Low risk & Double-blind \\
\hline $\begin{array}{l}\text { Blinding - Operator/seda- } \\
\text { tionist }\end{array}$ & Low risk & Double-blind \\
\hline $\begin{array}{l}\text { Blinding - Outcome asses- } \\
\text { sor }\end{array}$ & Low risk & $\begin{array}{l}\text { Quote: "Behaviour of the child during treatment was evaluated by a trained } \\
\text { observer who was also blind to the drug regimen used" }\end{array}$ \\
\hline $\begin{array}{l}\text { Incomplete outcome as- } \\
\text { sessment }\end{array}$ & High risk & $\begin{array}{l}\text { Number of participants included in outcome evaluation unclear as only per- } \\
\text { centage given }\end{array}$ \\
\hline Free of selective reporting & Low risk & Depth of sedation, time to onset of sedation and Houpt scores reported \\
\hline Free of other bias & High risk & No characteristics of the groups at baseline are reported \\
\hline
\end{tabular}

\section{Alfonzo-Echeverri 1993}

\begin{tabular}{ll}
\hline Methods & Parallel design \\
& Funding: not stated
\end{tabular}


Alfonzo-Echeverri 1993 (Continued)

$$
\text { Location: USA }
$$

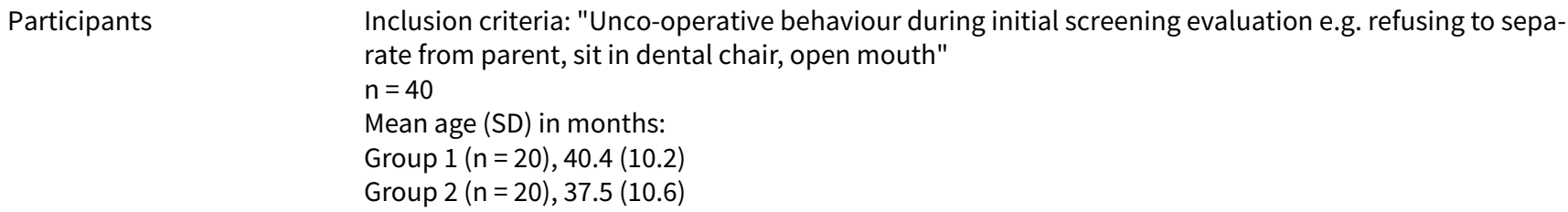

$\begin{array}{ll}\text { Interventions } & \text { Group 1: ketamine }(6 \mathrm{mg} / \mathrm{kg}) \\ & \text { Group 2: meperidine }(2.0 \mathrm{mg} / \mathrm{kg})+\text { promethazine }(0.5 \mathrm{mg} / \mathrm{kg}) \\ & \text { All oral, administered by paediatric anaesthesiologist }\end{array}$

\begin{tabular}{ll}
\hline Outcomes & Modified Houpt \\
\hline Notes & Papoose board (loose straps) \\
& 30-50:50 nitrous oxide/oxygen given to all participants
\end{tabular}

\section{Risk of bias}

\begin{tabular}{|c|c|c|}
\hline Bias & Authors' judgement & Support for judgement \\
\hline $\begin{array}{l}\text { Random sequence genera- } \\
\text { tion (selection bias) }\end{array}$ & Unclear risk & "Patients were randomised" - method of sequence generation not described \\
\hline $\begin{array}{l}\text { Allocation concealment } \\
\text { (selection bias) }\end{array}$ & Unclear risk & Not described \\
\hline Blinding - Participant & Low risk & Both drugs masked using flavoured soft drink \\
\hline $\begin{array}{l}\text { Blinding - Operator/seda- } \\
\text { tionist }\end{array}$ & Low risk & Quote: "operating dentist was not aware of which drug the child received" \\
\hline $\begin{array}{l}\text { Blinding - Outcome asses- } \\
\text { sor }\end{array}$ & Low risk & $\begin{array}{l}\text { Quote: "The quality of the sedation was assessed by the operating dentist who } \\
\text { was blinded to the study drug" }\end{array}$ \\
\hline $\begin{array}{l}\text { Incomplete outcome as- } \\
\text { sessment }\end{array}$ & Low risk & All patients included in outcome evaluation \\
\hline Free of selective reporting & Low risk & All planned outcomes reported \\
\hline Free of other bias & High risk & $\begin{array}{l}\text { Nitrous oxide/oxygen titrated to desired effect - this is a co-intervention. Lev- } \\
\text { els of nitrous oxide not reported }\end{array}$ \\
\hline
\end{tabular}

Avalos-Arenas 1998

\begin{tabular}{ll}
\hline Methods & Parallel design RCT \\
& Funding: not stated \\
& Location: Mexico \\
\hline Participants & Inclusion criteria: ASA I healthy children undergoing dental procedures \\
& $\mathrm{n}=40$ \\
Mean age $(\mathrm{SD})$ in months and gender: \\
Group $1(\mathrm{n}=20), 27.7(2.9), 13$ male, 7 female
\end{tabular}


Avalos-Arenas 1998 (Continued)

Group $2(n=20), 29.2(3.6), 14$ male, 6 female

Interventions Group 1: chloral hydrate $(70 \mathrm{mg} / \mathrm{kg})+$ placebo

Group 2: chloral hydrate $(70 \mathrm{mg} / \mathrm{kg})+$ hydroxyzine $(2 \mathrm{mg} / \mathrm{kg})$

All oral, administered by nurse

\begin{tabular}{ll}
\hline Outcomes & Houpt \\
\hline Notes & Papoose board
\end{tabular}

\section{Risk of bias}

\begin{tabular}{|c|c|c|}
\hline Bias & Authors' judgement & Support for judgement \\
\hline $\begin{array}{l}\text { Random sequence genera- } \\
\text { tion (selection bias) }\end{array}$ & Unclear risk & "Randomly assigned" - method of sequence generation not described \\
\hline $\begin{array}{l}\text { Allocation concealment } \\
\text { (selection bias) }\end{array}$ & Unclear risk & Not described \\
\hline Blinding - Participant & Low risk & Study described as double-blind \\
\hline $\begin{array}{l}\text { Blinding - Operator/seda- } \\
\text { tionist }\end{array}$ & Low risk & $\begin{array}{l}\text { Quote: "dental procedures were completed by one dentist who was ignorant } \\
\text { of the patient location group" }\end{array}$ \\
\hline $\begin{array}{l}\text { Blinding - Outcome asses- } \\
\text { sor }\end{array}$ & Low risk & $\begin{array}{l}\text { Study described as double-blind, independent rater unaware of patient treat- } \\
\text { ment }\end{array}$ \\
\hline $\begin{array}{l}\text { Incomplete outcome as- } \\
\text { sessment }\end{array}$ & High risk & Numbers evaluated not stated \\
\hline Free of selective reporting & Low risk & All planned outcomes reported \\
\hline Free of other bias & Low risk & No other bias \\
\hline
\end{tabular}

Averley 2004a

\begin{tabular}{ll}
\hline Methods & Pilot study, parallel group \\
& Funding: NHS R\&D Award \\
& Location: UK \\
\hline Participants & Inclusion criteria: healthy children aged 6 to 14 years who are anxious (Wong \& Baker scale), unco-oper- \\
& ative (Venham scale) requiring 'invasive' dental procedures \\
& $\mathrm{n}=65$ randomised \\
& Mean age $(\mathrm{SD})$ in years, gender, weight $(\mathrm{SD}) \mathrm{kg}:$ \\
& Group $1(\mathrm{n}=20), 9.3(2.2), 13$ males and 7 females, $33.6(11.2)$ \\
& Group $2(\mathrm{n}=22), 9.6(2.3), 15$ males and 5 females, $37.6(14.6)$ \\
& Group $3(\mathrm{n}=23), 9.9(2.2), 4$ males and 16 females, $36.1(11.8)$
\end{tabular}

Interventions Group 1: midazolam (IV) $(0.5 \mathrm{mg} / \mathrm{min})+$ air (nasal inhalation)

Group 2: midazolam (IV) $(0.5 \mathrm{mg} / \mathrm{min}$ titrated) + nitrous oxide (40\%) (nasal inhalation)

Group 3: midazolam (IV) $(0.5 \mathrm{mg} / \mathrm{min}$ titrated) + nitrous oxide (40\%) (nasal inhalation) + sevoflurane

(0.3\%) (nasal inhalation) 
Averley 2004a (Continued)

$$
\text { Administered by anaesthetist }
$$

Outcomes Primary: completion of treatment

Secondary: level of co-operation during treatment, recovery time, perception of anxiety and pain and parent's satisfaction

\begin{tabular}{ll}
\hline Notes & Secondary outcomes reported only for successful sedations \\
Dr Averley was contacted to clarify blinding and to enquire about any unpublished literature on con- \\
scious sedation
\end{tabular}

\section{Risk of bias}

\begin{tabular}{|c|c|c|}
\hline Bias & Authors' judgement & Support for judgement \\
\hline $\begin{array}{l}\text { Random sequence genera- } \\
\text { tion (selection bias) }\end{array}$ & Low risk & $\begin{array}{l}\text { Computerised random number generation "used Newcastle Centre for Health } \\
\text { Services Research web-based randomisation service" }\end{array}$ \\
\hline $\begin{array}{l}\text { Allocation concealment } \\
\text { (selection bias) }\end{array}$ & Low risk & $\begin{array}{l}\text { Envelope which had been placed in patient's record card opened by anaes- } \\
\text { thetist }\end{array}$ \\
\hline Blinding - Participant & Low risk & Blinded \\
\hline $\begin{array}{l}\text { Blinding - Operator/seda- } \\
\text { tionist }\end{array}$ & Low risk & Dentist blinded to sedation type. Anaesthetist not blinded \\
\hline $\begin{array}{l}\text { Blinding - Outcome asses- } \\
\text { sor }\end{array}$ & Low risk & Outcomes assessed by dentist \\
\hline $\begin{array}{l}\text { Incomplete outcome as- } \\
\text { sessment }\end{array}$ & High risk & $\begin{array}{l}\text { ITT analysis done initially. However, secondary outcomes only reported on } \\
\text { 'successful sedations' (69\% of those randomised) }\end{array}$ \\
\hline Free of selective reporting & High risk & All planned outcomes reported, but not for all participants \\
\hline Free of other bias & Unclear risk & Some imbalance in the groups - gender and invasiveness of treatment \\
\hline
\end{tabular}

Averley 2004b

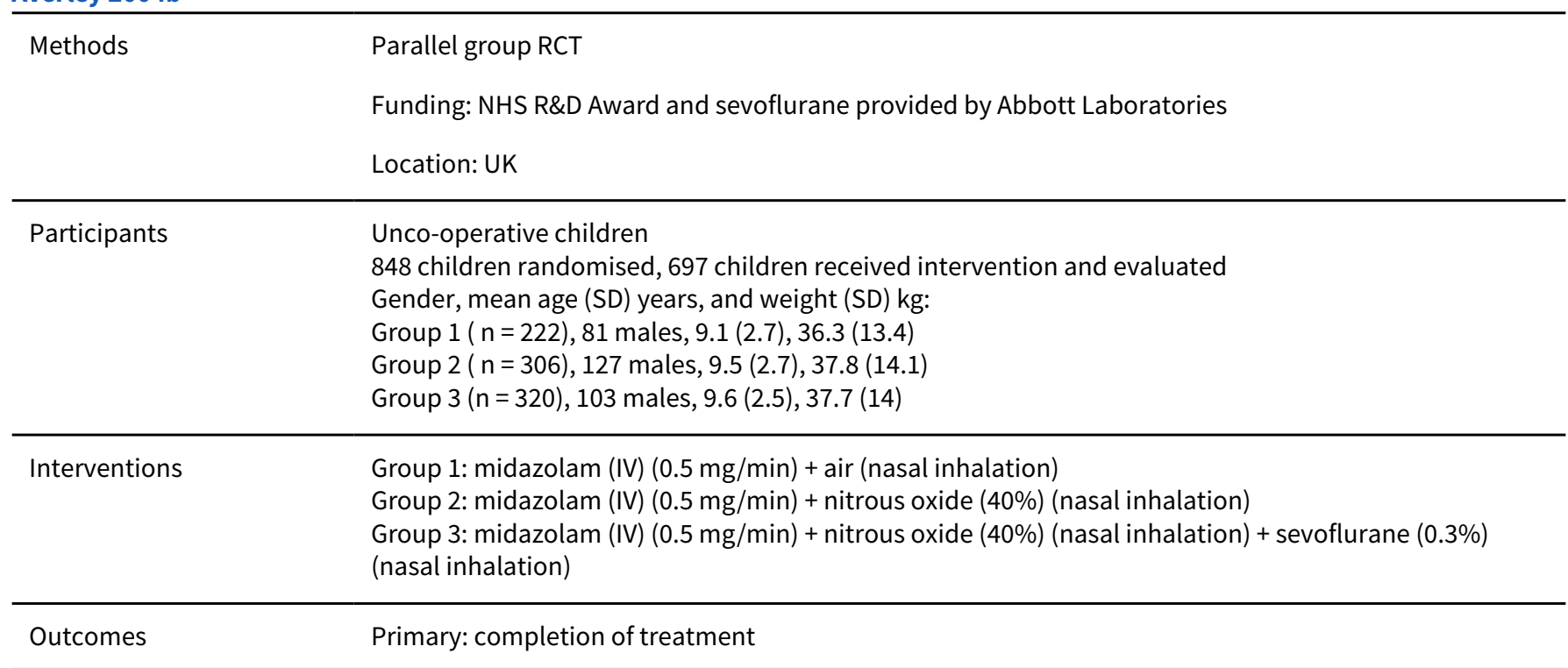


Averley 2004b (Continued)

Secondary: level of co-operation during treatment, recovery time, perception of anxiety and pain and parent's satisfaction

\begin{tabular}{|c|c|c|}
\hline Notes & $\begin{array}{l}\text { Secondary outcomes } r \\
\text { Anaesthetist involvem } \\
\text { Group } 1 \text { not included i }\end{array}$ & $\begin{array}{l}\text { norted only for successful sedations } \\
\text { the analysis }\end{array}$ \\
\hline \multicolumn{3}{|l|}{ Risk of bias } \\
\hline Bias & Authors' judgement & Support for judgement \\
\hline $\begin{array}{l}\text { Random sequence genera- } \\
\text { tion (selection bias) }\end{array}$ & Low risk & Computerised random number generation \\
\hline $\begin{array}{l}\text { Allocation concealment } \\
\text { (selection bias) }\end{array}$ & Low risk & Allocated by independent third person \\
\hline Blinding - Participant & Low risk & Blinded \\
\hline $\begin{array}{l}\text { Blinding - Operator/seda- } \\
\text { tionist }\end{array}$ & Low risk & $\begin{array}{l}\text { Sedation administered by anaesthetist. Dentist unaware of allocated treat- } \\
\text { ment }\end{array}$ \\
\hline $\begin{array}{l}\text { Blinding - Outcome asses- } \\
\text { sor }\end{array}$ & Low risk & Dentist blinded to allocated treatment undertook outcome assessments \\
\hline $\begin{array}{l}\text { Incomplete outcome as- } \\
\text { sessment }\end{array}$ & High risk & $\begin{array}{l}848 \text { children randomised and } 697 \text { received intervention and were analysed. } \\
22 \%, 16 \% \text { and } 17 \% \text { of children randomised to groups } 1,2 \text { and } 3 \text { did not receive } \\
\text { allocated treatment. Paper states ITT performed but this appears to be only on } \\
\text { those who received treatment ( } 82 \% \text { of those randomised) }\end{array}$ \\
\hline Free of selective reporting & High risk & $\begin{array}{l}\text { All planned outcomes reported, but secondary outcomes only reported for } \\
\text { 'successful' sedations ( } 65 \% \text { of those initially randomised) }\end{array}$ \\
\hline Free of other bias & High risk & $\begin{array}{l}\text { Baseline data only reported for those who received treatment. Unbalanced for } \\
\text { gender and anxiety. Interim analysis led to discontinuation of group } 1 \text { after } 222 \\
\text { children randomised }\end{array}$ \\
\hline
\end{tabular}

Aydintug 2004

\begin{tabular}{ll} 
Methods & Parallel group RCT \\
& Location: Turkey \\
& Funding: not stated \\
\hline Participants & Unco-operative (Frankl) \\
& Gender, mean age (unclear, possibly SD) in years, mean weight (unclear, possibly SD) in kg: \\
& Group 1 ( $\mathrm{n}=25), 18$ males, 7 females, 5.36 (1.7), 19.068 (3.43) \\
& Group 2 $(\mathrm{n}=25), 12$ males, 13 females, $4.96(1.513), 17.804(3.08)$
\end{tabular}


Aydintug 2004 (Continued)

Group 2: midazolam (0.35 mg/kg) (rectal)

Outcomes Ramsay Sedation Score, acceptance of local anaesthetic, acceptance of sedation, operating conditions

Notes

\section{Risk of bias}

\begin{tabular}{lll}
\hline Bias & Authors' judgement & Support for judgement \\
\hline $\begin{array}{l}\text { Random sequence genera- } \\
\text { tion (selection bias) }\end{array}$ & Unclear risk & "Randomly chosen" - method of sequence generation not described \\
\hline $\begin{array}{l}\text { Allocation concealment } \\
\text { (selection bias) }\end{array}$ & Unclear risk & Not described \\
\hline Blinding - Participant & High risk & No blinding \\
\hline $\begin{array}{l}\text { Blinding - Operator/seda- } \\
\text { tionist }\end{array}$ & High risk & No blinding \\
\hline $\begin{array}{l}\text { Blinding - Outcome asses- } \\
\text { sor }\end{array}$ & High risk & No blinding \\
\hline $\begin{array}{l}\text { Incomplete outcome as- } \\
\text { sessment }\end{array}$ & High risk & Numbers evaluated not stated \\
\hline $\begin{array}{l}\text { Free of selective reporting } \\
\text { Free of other bias }\end{array}$ & Low risk & Low risk \\
\hline
\end{tabular}

\section{Baygin 2010}

\begin{tabular}{|c|c|}
\hline Methods & $\begin{array}{l}\text { Parallel group RCT } \\
\text { Location: Turkey } \\
\text { Funding: not stated }\end{array}$ \\
\hline Participants & $\begin{array}{l}\text { Unco-operative (Frankl > 3) } \\
n=60(n=15 \text { per group) } \\
\text { Gender, mean age (unclear, possibly SD) in years, mean weight (unclear, possibly SD) in kg: } \\
\text { Group } 1(n=15), 10 \text { males, } 5 \text { females, } 5.33(0.62), 18.93(2.31) \\
\text { Group } 2(n=15), 11 \text { males, } 4 \text { females, } 5.27(0.80), 19.07(3.62) \\
\text { Group } 3(n=15), 9 \text { males, } 6 \text { females, } 5.20(0.41), 18.20(2.34) \\
\text { Group } 4(n=15), 6 \text { males, } 9 \text { females, } 5.53(0.99), 20.01(3.99)\end{array}$ \\
\hline Interventions & $\begin{array}{l}\text { Group 1: hydroxyzine }(1 \mathrm{mg} / \mathrm{kg}) \text { (oral) }+40 \% \text { nitrous oxide oxygen } \\
\text { Group 2: midazolam }(0.7 \mathrm{mg} / \mathrm{kg})+40 \% \text { nitrous oxide oxygen } \\
\text { Group 3: ketamine }(3 \mathrm{mg} / \mathrm{kg})+\text { midazolam }(0.25 \mathrm{mg} / \mathrm{kg})+40 \% \text { nitrous oxide oxygen }\end{array}$ \\
\hline
\end{tabular}


Baygin 2010 (Continued)

Group 4: 40\% nitrous oxide oxygen

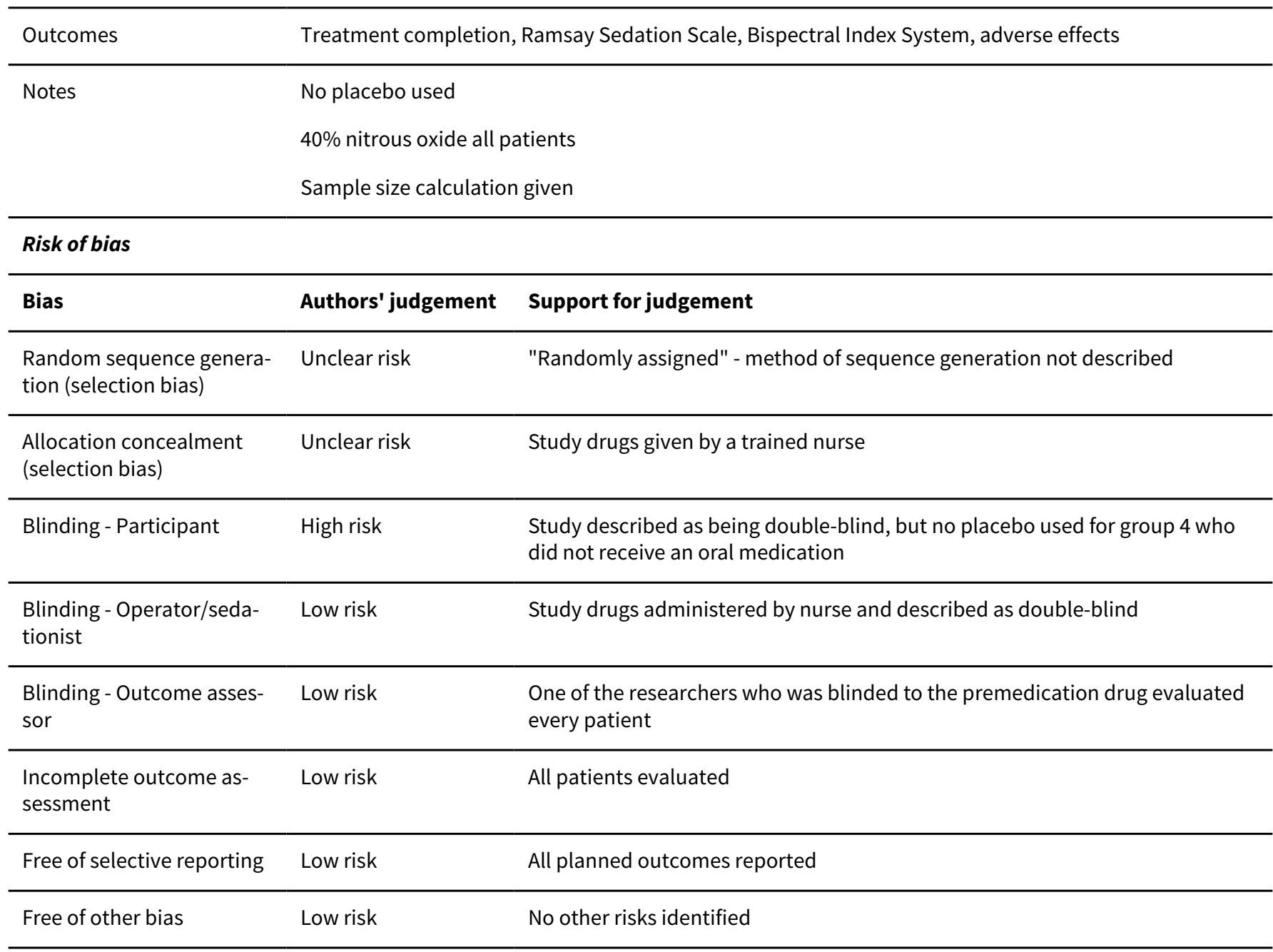

Bhatnagar 2012

\begin{tabular}{ll} 
Methods & Parallel design \\
& Funding: not stated \\
& Location: India \\
\hline Participants & Inclusion criteria: patient who exhibited fearful or refractory behaviour at previous dental appoint- \\
& ments, as documented by Frankl behaviour rating scale \\
& $\mathrm{n}=60$ \\
& Age range = 3 to 9 years \\
\hline Interventions & Group 1: midazolam $(0.5 \mathrm{mg} / \mathrm{kg}$ body weight $)$ \\
& Group 2: tramadol $(2 \mathrm{mg} / \mathrm{kg}$ body weight $)$ \\
Group 3: triclofos $(70 \mathrm{mg} / \mathrm{kg}$ body weight $)$ \\
Group 4: zolpidem $(0.4 \mathrm{mg} / \mathrm{kg}$ body weight $)$ \\
All orally
\end{tabular}


Bhatnagar 2012 (Continued)

\begin{tabular}{ll} 
Outcomes & Sedation rating scale, ease of treatment completion, recovery time \\
\hline Notes & $\begin{array}{l}\text { No additional drug was administered if the children spat the drug or vomited. The number of children } \\
\text { who spat the drug were not recorded }\end{array}$
\end{tabular}

\section{Risk of bias}

Bias

\section{Authors' judgement Support for judgement}

Random sequence genera- Unclear risk "Randomly assigned" - method of sequence generation not described tion (selection bias)

\begin{tabular}{|c|c|c|}
\hline $\begin{array}{l}\text { Allocation concealment } \\
\text { (selection bias) }\end{array}$ & Unclear risk & Not described \\
\hline Blinding - Participant & Unclear risk & Not described \\
\hline $\begin{array}{l}\text { Blinding - Operator/seda- } \\
\text { tionist }\end{array}$ & Unclear risk & Not described \\
\hline $\begin{array}{l}\text { Blinding - Outcome asses- } \\
\text { sor }\end{array}$ & Unclear risk & Not described \\
\hline $\begin{array}{l}\text { Incomplete outcome as- } \\
\text { sessment }\end{array}$ & Unclear risk & Not described \\
\hline Free of selective reporting & High risk & All planned outcomes not reported \\
\hline Free of other bias & High risk & No information on the demographic characteristic at baseline \\
\hline
\end{tabular}

\section{Bui 2002}

\begin{tabular}{ll}
\hline Methods & Parallel group RCT \\
& Location: USA \\
& Funding: not stated \\
\hline Participants & $\begin{array}{l}\text { Unco-operative children } \\
\mathrm{n}=22 \\
\text { Mean age }(\mathrm{SD}) \text { in months: } \\
\text { Group } 1(\mathrm{n}=11), 34(6.28) \\
\text { Group 2 }(\mathrm{n}=11), 33(6.65)\end{array}$ \\
\hline Interventions & Group 1: ketamine $(10 \mathrm{mg} / \mathrm{kg})+$ promethazine $(1.1 \mathrm{mg} / \mathrm{kg})$ \\
& Group 2: ketamine $(10 \mathrm{mg} / \mathrm{kg})$ \\
\hline Outcomes & Houpt, adverse effects \\
\hline Notes & $\begin{array}{l}\text { Papoose board } \\
\text { 35:65 nitrous oxide/oxygen given to all participants }\end{array}$ \\
\hline
\end{tabular}

\section{Risk of bias}


Bui 2002 (Continued)

\begin{tabular}{|c|c|c|}
\hline Bias & Authors' judgement & Support for judgement \\
\hline $\begin{array}{l}\text { Random sequence genera- } \\
\text { tion (selection bias) }\end{array}$ & Unclear risk & "Randomly selected" - method of sequence generation not described \\
\hline $\begin{array}{l}\text { Allocation concealment } \\
\text { (selection bias) }\end{array}$ & Unclear risk & Independent person randomly selected, allocated and administered \\
\hline Blinding - Participant & Low risk & $\begin{array}{l}\text { Study described as double-blind - operator, dentist/anaesthetist and patient } \\
\text { did not know which regimen was selected }\end{array}$ \\
\hline $\begin{array}{l}\text { Blinding - Operator/seda- } \\
\text { tionist }\end{array}$ & Low risk & $\begin{array}{l}\text { Study described as double-blind - operator, dentist/anaesthetist and patient } \\
\text { did not know which regimen was selected }\end{array}$ \\
\hline $\begin{array}{l}\text { Blinding - Outcome asses- } \\
\text { sor }\end{array}$ & Low risk & $\begin{array}{l}\text { Study described as double-blind - operator, dentist/anaesthetist and patient } \\
\text { did not know which regimen was selected }\end{array}$ \\
\hline $\begin{array}{l}\text { Incomplete outcome as- } \\
\text { sessment }\end{array}$ & Low risk & All randomised participants evaluated \\
\hline Free of selective reporting & Low risk & All planned outcomes reported \\
\hline Free of other bias & Low risk & No other bias \\
\hline
\end{tabular}

Eshghi 2016

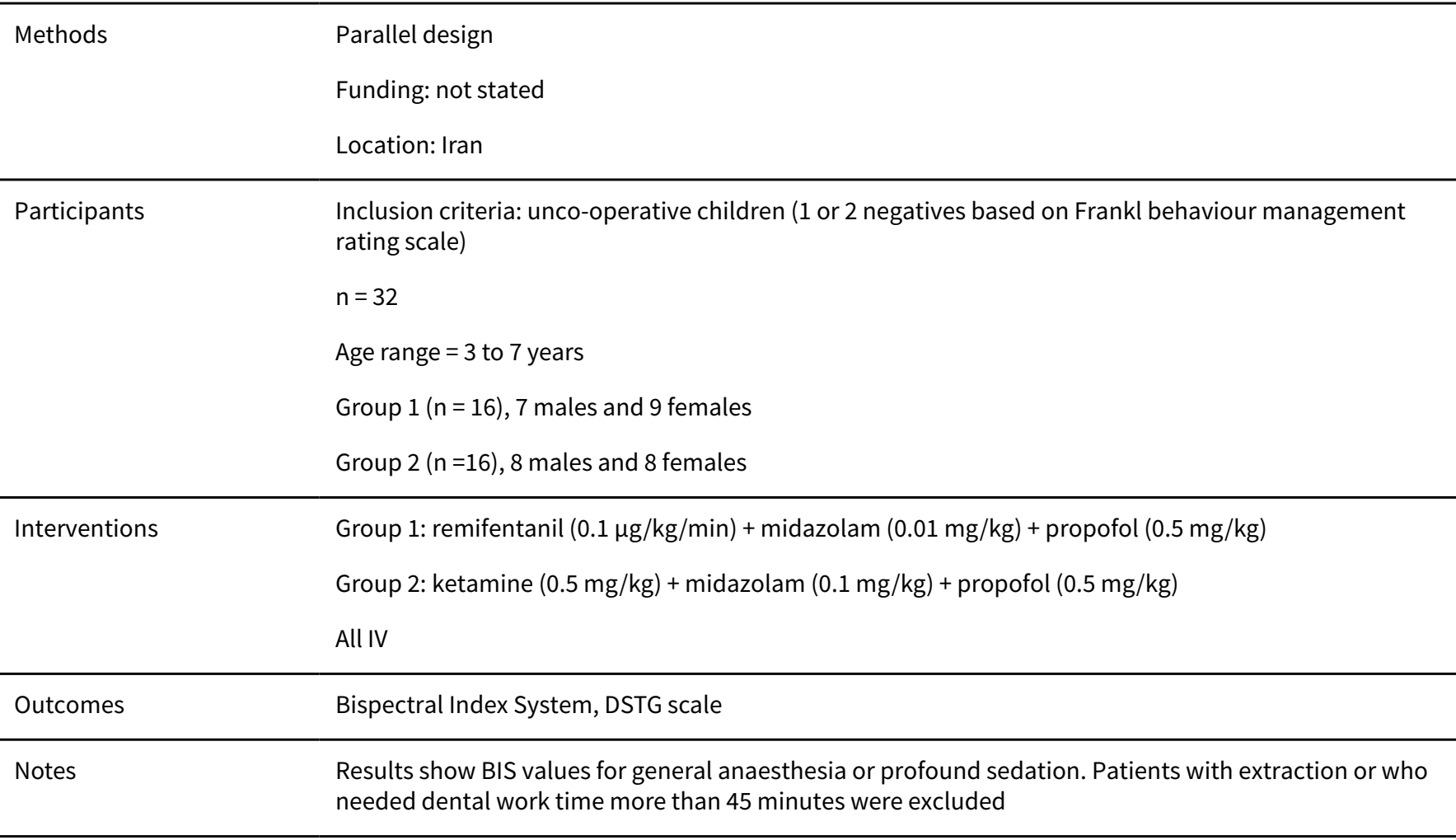

\section{Risk of bias}

\section{Bias}

Authors' judgement Support for judgement 
Eshghi 2016 (Continued)

Random sequence genera- Low risk Quotes: "On the day of the procedure each subject was given a code of which tion (selection bias)

only the anethesiologist was aware" and "patients were randomly divided into

2 groups based on odd or even code"

\begin{tabular}{lll}
\hline $\begin{array}{l}\text { Allocation concealment } \\
\text { (selection bias) }\end{array}$ & Unclear risk & Not described \\
\hline Blinding - Participant & Low risk & Study described as double-blinded \\
\hline $\begin{array}{l}\text { Blinding - Operator/seda- } \\
\text { tionist }\end{array}$ & High risk & $\begin{array}{l}\text { Study described as double-blinded and operator blinded but the sedationist } \\
\text { (anaesthesiologist) not blinded }\end{array}$ \\
\hline $\begin{array}{l}\text { Blinding - Outcome asses- } \\
\text { sor }\end{array}$ & High risk & The BIS score was recorded by the anaesthesiologist \\
\hline $\begin{array}{l}\text { Incomplete outcome as- } \\
\text { sessment }\end{array}$ & Low risk & All randomised participants evaluated \\
\hline $\begin{array}{l}\text { Free of selective reporting } \\
\text { Free of other bias }\end{array}$ & Low risk & High risk \\
\hline
\end{tabular}

Faytrouny 2007

\begin{tabular}{|c|c|}
\hline \multirow[t]{3}{*}{ Methods } & Parallel group RCT \\
\hline & Funding: not stated \\
\hline & Location: Turkey \\
\hline \multirow[t]{5}{*}{ Participants } & $\begin{array}{l}\text { Inclusion criteria: unco-operative fearful healthy children, ASA I, requiring sedation due to Frankl score } \\
\text { of definitely negative or negative }\end{array}$ \\
\hline & $\mathrm{n}=30,14$ females, 16 males \\
\hline & Mean age (SD) months: \\
\hline & Group $1(n=15), 61.9(11.9)$ \\
\hline & Group $2(n=15), 53.7(12.8)$ \\
\hline \multirow[t]{3}{*}{ Interventions } & Group 1: hydroxyzine (20 mg 24 hours before) + hydroxyzine (3.7 mg/kg at the appointment) \\
\hline & Group 2: hydroxyzine (3.7 mg/kg at the appointment) \\
\hline & All oral \\
\hline Outcomes & Houpt \\
\hline \multirow[t]{3}{*}{ Notes } & $\begin{array}{l}20 \mathrm{mg} / \mathrm{kg} \text { as stated in the text a mistake as this appears to be high. } 20 \mathrm{mg} \text { in the abstract, presumably } \\
\text { this is the correct value }\end{array}$ \\
\hline & 50:50 nitrous oxide/oxygen given to all participants \\
\hline & Pediwrap used after sedation achieved \\
\hline
\end{tabular}

\section{Risk of bias}

Sedation of children undergoing dental treatment (Review)

Copyright $\odot 2018$ The Cochrane Collaboration. Published by John Wiley \& Sons, Ltd. 
Faytrouny 2007 (Continued)

\begin{tabular}{|c|c|c|}
\hline Bias & Authors' judgement & Support for judgement \\
\hline $\begin{array}{l}\text { Random sequence genera- } \\
\text { tion (selection bias) }\end{array}$ & Unclear risk & $\begin{array}{l}\text { "Subjects were assigned randomly" - method of sequence generation not de- } \\
\text { scribed }\end{array}$ \\
\hline $\begin{array}{l}\text { Allocation concealment } \\
\text { (selection bias) }\end{array}$ & Unclear risk & Not described \\
\hline Blinding - Participant & High risk & Drugs given at home by parents or administered at clinic by the assistant \\
\hline $\begin{array}{l}\text { Blinding - Operator/seda- } \\
\text { tionist }\end{array}$ & Low risk & Quote: "Blinded to subject group assignment" \\
\hline $\begin{array}{l}\text { Blinding - Outcome asses- } \\
\text { sor }\end{array}$ & Unclear risk & $\begin{array}{l}\text { Outcomes assessed by the "monitoring dentist." Unclear whether this person } \\
\text { was blinded to treatment }\end{array}$ \\
\hline $\begin{array}{l}\text { Incomplete outcome as- } \\
\text { sessment }\end{array}$ & High risk & Numbers evaluated not stated \\
\hline Free of selective reporting & Low risk & All planned outcomes reported \\
\hline Free of other bias & Low risk & No other bias \\
\hline
\end{tabular}

Gallardo 1994

\begin{tabular}{ll}
\hline Methods & Parallel group RCT \\
& Location: Chile \\
& Funding: not stated \\
\hline Participants & $\begin{array}{l}\text { Inclusion criteria: children referred to pedodontic clinic for treatment after treatment refusal following } \\
\text { conventional psychological approach } \\
\mathrm{n}=32, \text { age range }=4 \text { to } 10 \text { years } \\
17 \text { male, } 15 \text { female }\end{array}$ \\
\hline Interventions & $\begin{array}{l}\text { Group 1: midazolam (7.5 mg) } \\
\text { Group 2: placebo } \\
\text { All oral, administered by dental assistant }\end{array}$ \\
\hline Outcomes & Overall sedation, mental attitude, hypnotic effects, motor activity, ease of treatment \\
\hline Notes & \\
\hline
\end{tabular}

\section{Risk of bias}

\begin{tabular}{lll}
\hline Bias & Authors' judgement & Support for judgement \\
\hline $\begin{array}{l}\text { Random sequence genera- } \\
\text { tion (selection bias) }\end{array}$ & Unclear risk & "Randomly assigned" - method of sequence generation not described \\
\hline $\begin{array}{l}\text { Allocation concealment } \\
\text { (selection bias) }\end{array}$ & Unclear risk & Not described \\
\hline Blinding - Participant & Low risk & Study described as double-blind \\
\hline
\end{tabular}


Gallardo 1994 (Continued)

\begin{tabular}{lll}
$\begin{array}{l}\text { Blinding - Operator/seda- } \\
\text { tionist }\end{array}$ & High risk & $\begin{array}{l}\text { Study described as double-blind but likely that sedative effects of active inter- } \\
\text { vention were obvious to dentist }\end{array}$ \\
\hline $\begin{array}{l}\text { Blinding - Outcome asses- } \\
\text { sor }\end{array}$ & Low risk & Study described as double-blind \\
\hline $\begin{array}{l}\text { Incomplete outcome as- } \\
\text { sessment }\end{array}$ & High risk & Numbers evaluated not stated \\
\hline $\begin{array}{l}\text { Free of selective reporting } \\
\text { Free of other bias }\end{array}$ & Low risk & All planned outcomes reported on
\end{tabular}

Gomes 2017

\begin{tabular}{|c|c|c|}
\hline \multirow[t]{3}{*}{ Methods } & \multicolumn{2}{|l|}{ Parallel RCT } \\
\hline & \multicolumn{2}{|l|}{ Funding: government } \\
\hline & \multicolumn{2}{|l|}{ Location: Brazil } \\
\hline \multirow[t]{4}{*}{ Participants } & \multicolumn{2}{|c|}{ Inclusion criteria: children requiring sedation for dental procedures } \\
\hline & \multicolumn{2}{|c|}{ Mean age (SD) in years, gender, mean weight ( $25 \%$ median to $75 \%)$ in kg: } \\
\hline & \multicolumn{2}{|c|}{ Group $1(n=13), 4.7(0.6), 10$ males, 3 females, $16.5(15.7,19.6)$} \\
\hline & \multicolumn{2}{|c|}{ Group $2(n=14), 5.2(0.8), 8$ males, 6 females, $19.6(16.7,23.9)$} \\
\hline \multirow[t]{2}{*}{ Interventions } & \multicolumn{2}{|c|}{ Group 1: midazolam $(0.5 \mathrm{mg} / \mathrm{kg})+$ ketamine $(3 \mathrm{mg} / \mathrm{kg})$ (oral) } \\
\hline & \multicolumn{2}{|c|}{$\begin{array}{l}\text { Group 2: midazolam }(0.5 \mathrm{mg} / \mathrm{kg}) \text { (oral) + ketamine }(3 \mathrm{mg} / \mathrm{kg}) \text { (oral) + sevoflurane }(0.1 \% \text { to } 0.4 \%) \text { (inhala- } \\
\text { tion) }\end{array}$} \\
\hline Outcomes & \multicolumn{2}{|l|}{ Houpt, adverse events } \\
\hline \multicolumn{3}{|l|}{ Notes } \\
\hline \multicolumn{3}{|l|}{ Risk of bias } \\
\hline Bias & Authors' judgement & Support for judgement \\
\hline $\begin{array}{l}\text { Random sequence genera- } \\
\text { tion (selection bias) }\end{array}$ & Low risk & $\begin{array}{l}\text { Quote: "1 researcher that did not participate in the interventions and out- } \\
\text { comes assessments } \\
\text { created a computer-generated list through the website Randomization.com } \\
\text { (www.randomization.com)" }\end{array}$ \\
\hline $\begin{array}{l}\text { Allocation concealment } \\
\text { (selection bias) }\end{array}$ & Low risk & $\begin{array}{l}\text { Quote: "Each child was assigned to a group at the day of the intervention ac- } \\
\text { cording to the consecutively numbered code generated in the list. As only the } \\
\text { physicians knew the codes, they assigned participants to interventions" }\end{array}$ \\
\hline Blinding - Participant & Low risk & Study reported as triple-blind \\
\hline $\begin{array}{l}\text { Blinding - Operator/seda- } \\
\text { tionist }\end{array}$ & Low risk & Study reported as triple-blind \\
\hline
\end{tabular}


Gomes 2017 (Continued)

\begin{tabular}{lll}
$\begin{array}{l}\text { Blinding - Outcome asses- } \\
\text { sor }\end{array}$ & Low risk & Study reported as triple-blind \\
\hline $\begin{array}{l}\text { Incomplete outcome as- } \\
\text { sessment }\end{array}$ & Low risk & All patients evaluated
\end{tabular}

\begin{tabular}{lll}
\hline Free of selective reporting & Low risk & All planned outcomes reported \\
\hline Free of other bias & Unclear risk & $\begin{array}{l}\text { More boys in Group 1 compared to Group 2. No significant differences in other } \\
\text { demographic characteristics }\end{array}$ \\
\hline
\end{tabular}

Isik 2008a

\begin{tabular}{ll}
\hline Methods & Parallel \\
& Funding: not stated \\
Location: Turkey \\
\hline
\end{tabular}

$\begin{array}{ll}\text { Participants } & \text { Inclusion criteria: children requiring sedation for dental proced } \\ \text { Mean age }(S D) \text { in years, gender, mean weight }(S D) \text { in } k: \\ \text { Group } 1(n=15), 4.87(0.99), 7 \text { males, } 8 \text { females, } 18.87(2.5) \\ \text { Group } 2(n=15), 4.93(1.11), 7 \text { males, } 8 \text { females, } 17.87 \text { (3.88) } \\ \text { Group } 3(n=15), 4.93(1.10), 8 \text { males, } 7 \text { females, } 18.6(3.31) \\ \text { Group } 4(n=15), 5.01(1.03), 9 \text { males, } 6 \text { females, } 19.73(4.77)\end{array}$

Interventions
Group 1: melatonin (3 mg) (60 minutes prior to treatment)
Group 3: midazolam $(0.75 \mathrm{mg} / \mathrm{kg})(15$ minutes prior to treatment)
Group 4: placebo (half group 15 minutes prior to treatment and half 60 minutes prior to treatment)
All oral, administered by nurse

\begin{tabular}{ll}
\hline Outcomes & Ramsay Sedation Score \\
\hline Notes & $40: 60$ nitrous oxide/oxygen given to all \\
& Sample size calculation given \\
\hline
\end{tabular}

\section{Risk of bias}

Bias Authors' judgement Support for judgement

Random sequence genera- Unclear risk $\quad$ "Randomly assigned" - method of sequence generation not described
tion (selection bias)

\begin{tabular}{lll}
\hline $\begin{array}{l}\text { Allocation concealment } \\
\text { (selection bias) }\end{array}$ & Unclear risk & Not described \\
\hline Blinding - Participant & Low risk & Study reported as double-blind \\
\hline
\end{tabular}


Isik 2008a (Continued)

$\begin{aligned} & \text { Blinding - Operator/seda- Low risk } \\ & \text { tionist }\end{aligned}$
$\begin{aligned} & \text { Quote: "neither the researcher nor the parents were informed which drug was } \\ & \text { administered" }\end{aligned}$
tionist administered"

\begin{tabular}{|c|c|c|}
\hline $\begin{array}{l}\text { Blinding - Outcome asses- } \\
\text { sor }\end{array}$ & Low risk & Study reported as double-blind \\
\hline $\begin{array}{l}\text { Incomplete outcome as- } \\
\text { sessment }\end{array}$ & Low risk & All patients evaluated \\
\hline Free of selective reporting & Low risk & All planned outcomes reported \\
\hline Free of other bias & Low risk & No apparent differences between the groups at baseline \\
\hline
\end{tabular}

Isik 2008b

\begin{tabular}{ll}
\hline Methods & Parallel group RCT \\
Location: Turkey \\
Funding: not stated \\
\hline
\end{tabular}

\begin{tabular}{ll}
\hline Participants & Unco-operative, Frankl scores 3, 4 \\
& Mean age $(S D)$ in years, gender, mean weight $(S D)$ in kg: \\
& Group $1(n=14), 4.6(1.2), 7$ males, 7 females, $15.6(2.8)$ \\
& Group $2(n=13), 4.4(1.0), 8$ males, 5 females, $16.2(2.4)$ \\
& Group $3(n=13), 4.4(0.9), 6$ males, 7 females, $16.1(2.4)$ \\
Group $4(n=13), 4.3(0.9), 5$ males, 8 females, $15.8(2.6)$
\end{tabular}

\begin{tabular}{ll}
\hline Interventions & Group 1: midazolam $(0.2 \mathrm{mg} / \mathrm{kg})$ \\
& Group 2: midazolam $(0.5 \mathrm{mg} / \mathrm{kg})$ \\
& Group 3: midazolam $(0.75 \mathrm{mg} / \mathrm{kg})$ \\
& Group 4: midazolam $(1 \mathrm{mg} / \mathrm{kg})$ \\
& All orally \\
\hline Outcomes & Ramsay Sedation Score \\
\hline Notes & $40: 60$ nitrous oxide/oxygen given to all \\
& Translated from Turkish \\
\hline
\end{tabular}

\section{Risk of bias}

\begin{tabular}{lll}
\hline Bias & Authors' judgement & Support for judgement \\
\hline $\begin{array}{l}\text { Random sequence genera- } \\
\text { tion (selection bias) }\end{array}$ & Unclear risk & "Randomized" - method of sequence generation not described \\
\hline $\begin{array}{l}\text { Allocation concealment } \\
\text { (selection bias) }\end{array}$ & Unclear risk & Not described \\
\hline
\end{tabular}


Isik 2008b (Continued)

\begin{tabular}{lll} 
Blinding - Participant & Low risk & Subject blinded \\
\hline $\begin{array}{l}\text { Blinding - Operator/seda- } \\
\text { tionist }\end{array}$ & Low risk & Dentist blinded \\
\hline $\begin{array}{l}\text { Blinding - Outcome asses- } \\
\text { sor }\end{array}$ & Unclear risk & Separate outcome assessor, blinding unclear \\
\hline $\begin{array}{l}\text { Incomplete outcome as- } \\
\text { sessment }\end{array}$ & Low risk & All patients evaluated \\
\hline Free of selective reporting & Low risk & All planned outcomes reported \\
\hline Free of other bias & Low risk & No other bias \\
\hline
\end{tabular}

\section{Jensen 1999}

\begin{tabular}{ll}
\hline Methods & Parallel group RCT \\
& Funding: grants from Swedish Dental Association \\
& Location: Sweden \\
\hline Participants & $\mathrm{n}=90$ \\
& Median age (age range) in months and gender: \\
& Group 1 ( $\mathrm{n}=45), 32(18$ to 44$), 23$ male, 22 female \\
\hline Interventions 2 ( $\mathrm{n}=45), 29(15$ to 44$), 23$ male, 22 female \\
\hline Group $1:$ diazepam $(0.7 \mathrm{mg} / \mathrm{kg})$ \\
Group 2: midazolam $(0.3 \mathrm{mg} / \mathrm{kg})$ \\
All rectal, administered by dentist \\
\hline Wotes & Wilton's sedation scale, acceptance of treatment (Holst) \\
\hline Drious sedation
\end{tabular}

\begin{tabular}{lll}
\hline Risk of bias & \\
\hline Bias & Authors' judgement & Support for judgement \\
\hline $\begin{array}{l}\text { Random sequence genera- } \\
\text { tion (selection bias) }\end{array}$ & Unclear risk & "Randomly allocated" - method of sequence generation not described \\
\hline $\begin{array}{l}\text { Allocation concealment } \\
\text { (selection bias) }\end{array}$ & Low risk & Coded bottles \\
\hline $\begin{array}{l}\text { Blinding - Participant } \\
\begin{array}{l}\text { Blinding - Operator/seda- } \\
\text { tionist }\end{array}\end{array}$ & Low risk & $\begin{array}{l}\text { Quote: "delivered by the pharmacy in coded bottles and neither the dentist } \\
\text { nor the parents knew which agent was being used" }\end{array}$ \\
\hline $\begin{array}{l}\text { Blinding - Outcome asses- } \\
\text { sor }\end{array}$ & Low risk & $\begin{array}{l}\text { Quote: "delivered by the pharmacy in coded bottles and neither the dentist } \\
\text { nor the parents knew which agent was being used" }\end{array}$ \\
\hline
\end{tabular}


Jensen 1999 (Continued)

\begin{tabular}{lll}
$\begin{array}{l}\text { Incomplete outcome as- } \\
\text { sessment }\end{array}$ & High risk & Numbers evaluated not stated \\
\hline Free of selective reporting & Low risk & All planned outcomes reported \\
\hline Free of other bias & Low risk & No differences between groups at baseline \\
\hline
\end{tabular}

\section{Kapur 2004}

$\begin{array}{ll}\text { Methods } & \text { Parallel group RCT } \\ & \text { Location: India } \\ & \text { Funding: not stated }\end{array}$

Participants Potentially unco-operative (not measured), healthy children ASA I with $>1$ carious deciduous mandibular molar requiring a class II amalgam restoration $\mathrm{n}=40$

Age: younger than 4 years old - no differences at baseline with regards to age, sex and body weight

\begin{tabular}{ll}
\hline Interventions & $\begin{array}{l}\text { Group 1: midazolam }(0.5 \mathrm{mg} / \mathrm{kg}) \text { (oral/transmucosal) } \\
\text { Group 2: placebo (same volume) } \\
\text { Administered by chief investigator }\end{array}$ \\
\hline Outcomes & Completion of treatment, sedation time, treatment time \\
\hline Notes & Type of tooth or cavity matched for dental treatment \\
\hline
\end{tabular}

\section{Risk of bias}

\begin{tabular}{|c|c|c|}
\hline Bias & Authors' judgement & Support for judgement \\
\hline $\begin{array}{l}\text { Random sequence genera- } \\
\text { tion (selection bias) }\end{array}$ & Unclear risk & "Randomly divided" - method of sequence generation not described \\
\hline $\begin{array}{l}\text { Allocation concealment } \\
\text { (selection bias) }\end{array}$ & Unclear risk & Not described \\
\hline Blinding - Participant & Low risk & Study reported as double-blind \\
\hline $\begin{array}{l}\text { Blinding - Operator/seda- } \\
\text { tionist }\end{array}$ & Low risk & $\begin{array}{l}\text { "chief investigator blind to treatment allocation" - performed the restorative } \\
\text { procedures }\end{array}$ \\
\hline $\begin{array}{l}\text { Blinding - Outcome asses- } \\
\text { sor }\end{array}$ & Low risk & $\begin{array}{l}\text { "chief investigator blind to treatment allocation" - recorded the various para- } \\
\text { meters }\end{array}$ \\
\hline $\begin{array}{l}\text { Incomplete outcome as- } \\
\text { sessment }\end{array}$ & High risk & Numbers evaluated not stated \\
\hline Free of selective reporting & Low risk & All planned outcomes reported \\
\hline Free of other bias & Low risk & No differences at baseline with regards to age, sex and body weight \\
\hline
\end{tabular}


Kaviani 2015

\begin{tabular}{|c|c|c|}
\hline \multirow[t]{3}{*}{ Methods } & \multicolumn{2}{|l|}{ Parallel design } \\
\hline & \multicolumn{2}{|l|}{ Funding: not stated } \\
\hline & \multicolumn{2}{|l|}{ Location: Iran } \\
\hline \multirow[t]{6}{*}{ Participants } & \multicolumn{2}{|c|}{$\begin{array}{l}\text { Inclusion criteria: healthy children referred to dental operating room and needed treatment on "left up- } \\
\text { per teeth" }\end{array}$} \\
\hline & \multicolumn{2}{|l|}{$\mathrm{n}=38$} \\
\hline & \multicolumn{2}{|l|}{ Age range $=4$ to 9 years } \\
\hline & \multicolumn{2}{|c|}{ Gender, mean age in years: } \\
\hline & \multicolumn{2}{|c|}{ Group 1 midazolam-ketamine group ( $n=18$ ), 8 male, 10 female, 6.27} \\
\hline & \multicolumn{2}{|c|}{ Group 2 midazolam-fentanyl group ( $n=20), 12$ male, 8 female, 6.75} \\
\hline Interventions & \multicolumn{2}{|c|}{$\begin{array}{l}\text { GROUP 1: midazolam }(0.05 \mathrm{mg} / \mathrm{kg})+\text { ketamine }(0.5 \mathrm{mg} / \mathrm{kg}) \\
\text { GROUP 2: midazolam }(0.05 \mathrm{mg} / \mathrm{kg})+\text { fentanyl }(0.5 \mu \mathrm{g} / \mathrm{kg})\end{array}$} \\
\hline & \multicolumn{2}{|c|}{ All intravenous, administered by an anaesthesiologist } \\
\hline Outcomes & \multicolumn{2}{|c|}{ Dental sedation teacher groups system, Frankl behaviour rating scale } \\
\hline Notes & \multicolumn{2}{|c|}{ Additional midazolam $(0.25 \mathrm{mg})$ was administered to both groups if needed } \\
\hline \multicolumn{3}{|l|}{ Risk of bias } \\
\hline Bias & Authors' judgement & Support for judgement \\
\hline $\begin{array}{l}\text { Random sequence genera- } \\
\text { tion (selection bias) }\end{array}$ & Unclear risk & "Randomly assigned" - method of sequence generation not described \\
\hline $\begin{array}{l}\text { Allocation concealment } \\
\text { (selection bias) }\end{array}$ & Unclear risk & Not described \\
\hline Blinding - Participant & Unclear risk & Not described \\
\hline $\begin{array}{l}\text { Blinding - Operator/seda- } \\
\text { tionist }\end{array}$ & Low risk & Operating dentist not aware of the group he was treating \\
\hline $\begin{array}{l}\text { Blinding - Outcome asses- } \\
\text { sor }\end{array}$ & Low risk & $\begin{array}{l}\text { Quote: "Neither the dentist nor the person who was collecting data had a clue } \\
\text { about grouping method" }\end{array}$ \\
\hline $\begin{array}{l}\text { Incomplete outcome as- } \\
\text { sessment }\end{array}$ & High risk & Dropouts and failed sedation difficult to examine, typo errors in tables \\
\hline Free of selective reporting & Low risk & All planned outcomes reported \\
\hline Free of other bias & High risk & No information on the demographic characteristics at baseline \\
\hline
\end{tabular}

Koirala 2006

Methods Parallel group RCT


Koirala 2006 (Continued)

Location: Nepal

Funding: not stated

\begin{tabular}{ll}
\hline Participants & 6 experimental groups, $n=120$ \\
& Age range 2 to 9 years \\
\hline Interventions & Group $1(\mathrm{n}=20)$ : midazolam $(0.5 \mathrm{mg} / \mathrm{kg})$ \\
& Group $2(\mathrm{n}=20)$ : $\operatorname{ketamine}(5 \mathrm{mg} / \mathrm{kg})$ \\
& Group $3(\mathrm{n}=20):$ zolpidem $(0.4 \mathrm{mg} / \mathrm{kg})$ \\
& Group $4(\mathrm{n}=20):$ midazolam $(0.4 \mathrm{mg} / \mathrm{kg})+\operatorname{ketamine}(3 \mathrm{mg} / \mathrm{kg})$ \\
& Group $5(\mathrm{n}=20):$ midazolam $(0.5 \mathrm{mg} / \mathrm{kg})+\operatorname{tramadol}(2 \mathrm{mg} / \mathrm{kg})$ \\
& Group $6(\mathrm{n}=20):$ zolpidem $(0.4 \mathrm{mg} / \mathrm{kg})+\operatorname{tramadol}(2 \mathrm{mg} / \mathrm{kg})$ \\
& All oral
\end{tabular}

Outcomes

Onset of action, level of sedation, ease of treatment completion, recovery time, anterograde amnesia

\section{Notes}

\section{Risk of bias}

\begin{tabular}{|c|c|c|}
\hline Bias & Authors' judgement & Support for judgement \\
\hline $\begin{array}{l}\text { Random sequence genera- } \\
\text { tion (selection bias) }\end{array}$ & Unclear risk & "Randomly assigned" - method of sequence generation not described \\
\hline $\begin{array}{l}\text { Allocation concealment } \\
\text { (selection bias) }\end{array}$ & Unclear risk & Not described \\
\hline Blinding - Participant & Low risk & Study reported as double-blind \\
\hline $\begin{array}{l}\text { Blinding - Operator/seda- } \\
\text { tionist }\end{array}$ & Low risk & No separate outcome assessor described. Assumed dentist was blinded \\
\hline $\begin{array}{l}\text { Blinding - Outcome asses- } \\
\text { sor }\end{array}$ & Low risk & Study reported as double-blind \\
\hline $\begin{array}{l}\text { Incomplete outcome as- } \\
\text { sessment }\end{array}$ & High risk & Numbers evaluated not reported \\
\hline Free of selective reporting & Low risk & Planned outcomes reported \\
\hline Free of other bias & High risk & No characteristics of the groups at baseline are reported \\
\hline
\end{tabular}

Lahoud 2002

\begin{tabular}{ll} 
Methods & Parallel group RCT \\
& Location: UK \\
& Funding: Abbot Laboratories provided the sevoflurane \\
\hline
\end{tabular}


Lahoud 2002 (Continued)

Participants
Inclusion criteria: anxious children 3 to 10 years old able to sit in chair, tolerate dental exam, accept nasal hood, with unobstructed nasal airway

$\mathrm{n}=411$

Mean age (SD) in years:

Group $1(n=170), 6.2(1.9)$

Group $2(n=241), 6(1.7)$

\begin{tabular}{|c|c|c|}
\hline Interventions & \multicolumn{2}{|c|}{$\begin{array}{l}\text { Group 1: } 40: 60 \text { nitrous oxide/oxygen } \\
\text { Group 2: } 40: 60 \text { nitrous oxide/oxygen }+0.1 \% \text { to } 0.3 \% \text { sevoflurane } \\
\text { All inhalation, administered by anaesthetist }\end{array}$} \\
\hline Outcomes & \multicolumn{2}{|c|}{ Venham scale, level of sedation, treatment completion } \\
\hline \multicolumn{3}{|l|}{ Notes } \\
\hline \multicolumn{3}{|l|}{ Risk of bias } \\
\hline Bias & Authors' judgement & Support for judgement \\
\hline $\begin{array}{l}\text { Random sequence genera- } \\
\text { tion (selection bias) }\end{array}$ & Unclear risk & "randomly allocated" - method of sequence generation not described \\
\hline $\begin{array}{l}\text { Allocation concealment } \\
\text { (selection bias) }\end{array}$ & Low risk & $\begin{array}{l}\text { "allocated by means of sealed envelopes" - not stated whether these were } \\
\text { numbered }\end{array}$ \\
\hline Blinding - Participant & Unclear risk & Not described \\
\hline $\begin{array}{l}\text { Blinding - Operator/seda- } \\
\text { tionist }\end{array}$ & Unclear risk & Not described \\
\hline $\begin{array}{l}\text { Blinding - Outcome asses- } \\
\text { sor }\end{array}$ & Unclear risk & Not described \\
\hline $\begin{array}{l}\text { Incomplete outcome as- } \\
\text { sessment }\end{array}$ & Low risk & All randomised participants included in outcome evaluation \\
\hline Free of selective reporting & Low risk & All planned outcomes reported \\
\hline Free of other bias & Low risk & No reported differences between groups at baseline \\
\hline
\end{tabular}

Lam 2005

$\begin{array}{ll}\text { Methods } & \text { Parallel group RCT } \\ & \text { Location: USA } \\ & \text { Funding: not stated }\end{array}$

Participants

Inclusion criteria: healthy ASA I children with severe caries involving 2 or more quadrants, very anxious, unlikely to tolerate treatment with or without $\mathrm{N}_{2} \mathrm{O}$, requiring IV sedation. Unco-operative (no index used)

$\mathrm{n}=23,15$ males, 7 females

Mean age (range) in years: $5.13(2-9)$ 
Lam 2005 (Continued)

Mean weight (range) in kg: 21.74 (12-30)

\begin{tabular}{ll}
\hline Interventions & Group $1(\mathrm{n}=12):$ midazolam $(0.2 \mathrm{mg} / \mathrm{kg})$ (intramuscular) \\
& Group $2(\mathrm{n}=11):$ midazolam $(0.2 \mathrm{mg} / \mathrm{kg})$ (intranasal) \\
\hline Outcomes & All used as premedication for unspecified IV sedation drug. Drug administered by anaesthetist \\
\hline Notes & Houpt \\
\hline
\end{tabular}

\section{Risk of bias}

\begin{tabular}{|c|c|c|}
\hline Bias & Authors' judgement & Support for judgement \\
\hline $\begin{array}{l}\text { Random sequence genera- } \\
\text { tion (selection bias) }\end{array}$ & Unclear risk & "Randomly assigned" - method of sequence generation not described \\
\hline $\begin{array}{l}\text { Allocation concealment } \\
\text { (selection bias) }\end{array}$ & Unclear risk & Not described \\
\hline Blinding - Participant & High risk & Not possible \\
\hline $\begin{array}{l}\text { Blinding - Operator/seda- } \\
\text { tionist }\end{array}$ & High risk & Not blinded \\
\hline $\begin{array}{l}\text { Blinding - Outcome asses- } \\
\text { sor }\end{array}$ & Low risk & $\begin{array}{l}\text { Quote: "evaluators had no prior knowledge of which premedication route had } \\
\text { been used" }\end{array}$ \\
\hline $\begin{array}{l}\text { Incomplete outcome as- } \\
\text { sessment }\end{array}$ & High risk & Numbers evaluated unclear \\
\hline Free of selective reporting & Low risk & All planned outcomes reported \\
\hline Free of other bias & High risk & No characteristics of the groups at baseline are reported \\
\hline
\end{tabular}

Lee-Kim 2004

\begin{tabular}{ll}
\hline Methods & Parallel group RCT \\
& Location: USA \\
& Funding: not stated
\end{tabular}

Participants Inclusion criteria: healthy children ASA I requiring > 1 visits for comprehensive dental care, who demonstrated definitely or slightly negative behaviour on Frankl scale

$n=40$

Gender, mean age (unclear, possibly SD) in months, mean weight (unclear, possibly SD) in kg:

Group $1(\mathrm{n}=20), 11$ males, 9 females, $40.8(11), 17(3.6)$

Group $2(n=20), 10$ males, 10 females, $38.5(9.8), 16.2(4)$

Interventions Group 1: midazolam $(0.7 \mathrm{mg} / \mathrm{kg}$ ) (oral)


Lee-Kim 2004 (Continued)

Group 2: midazolam $(0.3 \mathrm{mg} / \mathrm{kg}$ ) (nasal)

Administered by dental provider

\begin{tabular}{ll}
\hline Outcomes & Modified Houpt, time of onset, duration of sedation \\
\hline Notes & $45 \%$ nitrous oxide all patients and papoose board
\end{tabular}

\section{Risk of bias}

\begin{tabular}{|c|c|c|}
\hline Bias & Authors' judgement & Support for judgement \\
\hline $\begin{array}{l}\text { Random sequence genera- } \\
\text { tion (selection bias) }\end{array}$ & Unclear risk & $\begin{array}{l}\text { "subjects randomly received..." - method of sequence generation not de- } \\
\text { scribed }\end{array}$ \\
\hline $\begin{array}{l}\text { Allocation concealment } \\
\text { (selection bias) }\end{array}$ & High risk & $\begin{array}{l}\text { Quote: "The principal investigator conducted subject selection and random } \\
\text { assignment of PO or IN midazolam administration" }\end{array}$ \\
\hline Blinding - Participant & High risk & Not possible \\
\hline $\begin{array}{l}\text { Blinding - Operator/seda- } \\
\text { tionist }\end{array}$ & High risk & Not possible \\
\hline $\begin{array}{l}\text { Blinding - Outcome asses- } \\
\text { sor }\end{array}$ & Low risk & Independent assessor using videotapes \\
\hline $\begin{array}{l}\text { Incomplete outcome as- } \\
\text { sessment }\end{array}$ & High risk & Numbers evaluated not stated \\
\hline Free of selective reporting & Low risk & All planned outcomes reported \\
\hline Free of other bias & Low risk & No apparent differences between groups at baseline \\
\hline
\end{tabular}

\section{Malhotra 2016}

\begin{tabular}{|c|c|}
\hline \multirow[t]{3}{*}{ Methods } & Parallel design RCT \\
\hline & Funding: not stated \\
\hline & Location: India \\
\hline \multirow[t]{5}{*}{ Participants } & $\begin{array}{l}\text { Inclusion criteria: ASA 1. Early childhood caries and negative behaviour according to Frankl behaviour } \\
\text { rating scale in their first visit at outpatients }\end{array}$ \\
\hline & $\mathrm{n}=36$ \\
\hline & Age range $=3$ to 9 years \\
\hline & Mean age (SD) in years: $4.60 \pm 1.99$ \\
\hline & Mean weight (SD) kg: $15.62 \pm 4.21$ \\
\hline \multirow[t]{3}{*}{ Interventions } & $\begin{array}{l}\text { Group 1: intranasal normal saline, oral midazolam }(0.5 \mathrm{mg} / \mathrm{kg})+\text { oral ketamine }(5 \mathrm{mg} / \mathrm{kg}) \text { in } 30 \mathrm{ml} \text { of } \\
\text { mango juice }\end{array}$ \\
\hline & Group 2: intranasal dexmedetomidine $(1 \mu / \mathrm{kg}), 30 \mathrm{ml}$ of mango juice \\
\hline & Group 3: intranasal normal saline, $30 \mathrm{ml}$ of mango juice \\
\hline
\end{tabular}


Malhotra 2016 (Continued)

\begin{tabular}{|c|c|c|}
\hline Outcomes & \multicolumn{2}{|c|}{ Modified Observer Assessment of Alertness and Sedation (MOAAS), Houpt scale } \\
\hline Notes & \multicolumn{2}{|c|}{ Participants in the groups not evenly distributed } \\
\hline Risk of bias & & \\
\hline Bias & Authors' judgement & Support for judgement \\
\hline $\begin{array}{l}\text { Random sequence genera- } \\
\text { tion (selection bias) }\end{array}$ & Low risk & Quote: "allocated to 1 of 3 groups by envelope draw method" \\
\hline $\begin{array}{l}\text { Allocation concealment } \\
\text { (selection bias) }\end{array}$ & Low risk & $\begin{array}{l}\text { Quote:"3 different color codes were decided for each group and were printed } \\
\text { and placed within envelope to eliminate any dissimilarity" }\end{array}$ \\
\hline Blinding - Participant & Unclear risk & Not described \\
\hline $\begin{array}{l}\text { Blinding - Operator/seda- } \\
\text { tionist }\end{array}$ & Low risk & $\begin{array}{l}\text { Quote: "performed by a single experienced pediatric dentist, who was blinded } \\
\text { to the study design" }\end{array}$ \\
\hline $\begin{array}{l}\text { Blinding - Outcome asses- } \\
\text { sor }\end{array}$ & Low risk & $\begin{array}{l}\text { Quote: "Evaluators and attending pedodontist were blinded to the study drug } \\
\text { given" }\end{array}$ \\
\hline $\begin{array}{l}\text { Incomplete outcome as- } \\
\text { sessment }\end{array}$ & Unclear risk & $\begin{array}{l}\text { Material and methods mention "about } 36 \text { " patients included in the study. Re- } \\
\text { sult table show count of } 36 \text { as sample size }\end{array}$ \\
\hline Free of selective reporting & Low risk & All planned outcomes reported \\
\hline Free of other bias & High risk & Little information on demographics of participants in each group at baseline \\
\hline
\end{tabular}

McKee 1990

\begin{tabular}{|c|c|}
\hline Methods & $\begin{array}{l}\text { Parallel group RCT } \\
\text { Location: USA } \\
\text { Funding: not stated }\end{array}$ \\
\hline Participants & $\begin{array}{l}\text { Inclusion criteria: healthy children } 2 \text { to } 5 \text { years old, Frankl scale behaviour negative or definitely nega- } \\
\text { tive, failed non-pharma management, requiring restorative treatment with LA and rotary instrument } \\
n=60 \\
\text { Mean age (SE) in months: } \\
\text { Group } 1(n=15), 36.5(2.7) \\
\text { Group } 2(n=15), 41.7(3) \\
\text { Group } 3(n=15), 35.9(2.7) \\
\text { Group } 4(n=15), 43(2.7)\end{array}$ \\
\hline Interventions & $\begin{array}{l}\text { Group 1: placebo } \\
\text { Group 2: meperidine }(0.25 \mathrm{mg} / \mathrm{lb}) \text { (approximately } 0.11 \mathrm{mg} / \mathrm{kg} \text { ) } \\
\text { Group 3: meperidine }(0.50 \mathrm{mg} / \mathrm{lb}) \text { (approximately } 0.22 \mathrm{mg} / \mathrm{kg} \text { ) } \\
\text { Group 4: meperidine }(1 \mathrm{mg} / \mathrm{lb}) \text { (approximately } 0.45 \mathrm{mg} / \mathrm{kg} \text { ) } \\
\text { All intramuscular, administered by "third party" }\end{array}$ \\
\hline Outcomes & $\begin{array}{l}\text { Modified Houpt, dichotomous behaviour scale, 10-point behaviour scale, global rating scale, adverse } \\
\text { effects }\end{array}$ \\
\hline
\end{tabular}


McKee 1990 (Continued)

Notes

\section{Risk of bias}

\begin{tabular}{|c|c|c|}
\hline Bias & Authors' judgement & Support for judgement \\
\hline $\begin{array}{l}\text { Random sequence genera- } \\
\text { tion (selection bias) }\end{array}$ & Unclear risk & "Randomly assigned" - method of sequence generation not described \\
\hline $\begin{array}{l}\text { Allocation concealment } \\
\text { (selection bias) }\end{array}$ & Unclear risk & Not described \\
\hline Blinding - Participant & Low risk & $\begin{array}{l}\text { Quote: "Dentist, patient and research observer were unaware of treatment al- } \\
\text { location" }\end{array}$ \\
\hline $\begin{array}{l}\text { Blinding - Operator/seda- } \\
\text { tionist }\end{array}$ & Low risk & $\begin{array}{l}\text { Quote: "Dentist, patient and research observer were unaware of treatment al- } \\
\text { location" }\end{array}$ \\
\hline $\begin{array}{l}\text { Blinding - Outcome asses- } \\
\text { sor }\end{array}$ & Low risk & $\begin{array}{l}\text { Quote: "Dentist, patient and research observer were unaware of treatment al- } \\
\text { location" }\end{array}$ \\
\hline $\begin{array}{l}\text { Incomplete outcome as- } \\
\text { sessment }\end{array}$ & Low risk & Dropouts/aborted patients reported \\
\hline Free of selective reporting & Low risk & All planned outcomes reported \\
\hline Free of other bias & Low risk & No apparent differences between groups at baseline \\
\hline
\end{tabular}

Meyer 1990

\begin{tabular}{ll}
\hline Methods & Parallel group RCT \\
& Location: USA \\
& Funding: not stated \\
\hline Participants & $\begin{array}{l}\text { Inclusion criteria: children who were unco-operative at screening visit, ASA I needing dental treatment } \\
\mathrm{n}=40 \\
\end{array}$ \\
& $\begin{array}{l}\text { Mean age (age range) in months: } \\
\text { Group 2 ( } \mathrm{n}=20) \text {, } 42 \text { (23 to } 64)\end{array}$ \\
\hline Interventions & $\begin{array}{l}\text { Group 1: triazolam (0.02 } \mathrm{mg} / \mathrm{kg}) \\
\text { Group 2: chloral hydrate }(40 \mathrm{mg} / \mathrm{kg})+\text { hydroxyzine }(25 \mathrm{mg}) \\
\text { All oral, administered by operating dentist }\end{array}$ \\
\hline Outcomes & Houpt \\
\hline Notes & $\begin{array}{l}\text { Papoose board } \\
50: 50 \text { nitrous oxide/oxygen given to all }\end{array}$ \\
\hline Risk of bias & Authors' judgement Support for judgement \\
\hline Bias & \\
\hline
\end{tabular}


Meyer 1990 (Continued)

\begin{tabular}{|c|c|c|}
\hline $\begin{array}{l}\text { Random sequence genera- } \\
\text { tion (selection bias) }\end{array}$ & Unclear risk & "Random administration" - method of sequence generation not described \\
\hline $\begin{array}{l}\text { Allocation concealment } \\
\text { (selection bias) }\end{array}$ & Unclear risk & Not described \\
\hline Blinding - Participant & Unclear risk & Not clear if the patient was blinded or not \\
\hline $\begin{array}{l}\text { Blinding - Operator/seda- } \\
\text { tionist }\end{array}$ & High risk & Operating dentist not blinded to drug given \\
\hline $\begin{array}{l}\text { Blinding - Outcome asses- } \\
\text { sor }\end{array}$ & Low risk & $\begin{array}{l}\text { Quote: "Sedations were videotaped and evaluated by } 2 \text { paediatric dentists not } \\
\text { involved in the study" }\end{array}$ \\
\hline $\begin{array}{l}\text { Incomplete outcome as- } \\
\text { sessment }\end{array}$ & High risk & Numbers evaluated unclear \\
\hline Free of selective reporting & Low risk & All planned outcomes reported \\
\hline Free of other bias & Low risk & No apparent differences between groups at baseline \\
\hline
\end{tabular}

Moody 1986

\begin{tabular}{ll}
\hline Methods & Parallel group RCT \\
& Location: USA \\
& Funding: not stated \\
\hline Participants & Inclusion criteria: healthy children aged 27 to 74 months who were unco-operative at previous appoint- \\
& ments and required dental restorations \\
& $\mathrm{n}=30$ \\
& Mean age in months: \\
& Group $1(\mathrm{n}=10), 39.6$ \\
& Group $2(\mathrm{n}=10), 42$ \\
& Group $3(\mathrm{n}=10), 38.4$
\end{tabular}

Interventions Group 1: chloral hydrate $(50 \mathrm{mg} / \mathrm{kg}$ ) (oral)

Group 2: chloral hydrate $(50 \mathrm{mg} / \mathrm{kg}$ ) (rectal)

Group 3: chloral hydrate (30 mg/kg) + hydroxyzine (25 mg) (oral)

All administered by operating dentist

\begin{tabular}{ll}
\hline Outcomes & Modified Barker, overall quality sedation \\
\hline Notes & $50: 50$ nitrous oxide/oxygen given to all, reduced to $30 \%$ to $40 \%$ after LA administered
\end{tabular}

\section{Risk of bias}

\begin{tabular}{lll}
\hline Bias & Authors' judgement & Support for judgement \\
\hline $\begin{array}{l}\text { Random sequence genera- } \\
\text { tion (selection bias) }\end{array}$ & Unclear risk & "Randomly placed" - method of sequence generation not described \\
\hline $\begin{array}{l}\text { Allocation concealment } \\
\text { (selection bias) }\end{array}$ & Unclear risk & Not described \\
\hline \hline
\end{tabular}


Moody 1986 (Continued)

\begin{tabular}{|c|c|c|}
\hline Blinding - Participant & High risk & Not possible \\
\hline $\begin{array}{l}\text { Blinding - Operator/seda- } \\
\text { tionist }\end{array}$ & High risk & Operator administered sedation \\
\hline $\begin{array}{l}\text { Blinding - Outcome asses- } \\
\text { sor }\end{array}$ & High risk & Operator administered sedation and assessed outcomes \\
\hline $\begin{array}{l}\text { Incomplete outcome as- } \\
\text { sessment }\end{array}$ & High risk & Numbers evaluated unclear \\
\hline Free of selective reporting & Low risk & All planned outcomes reported \\
\hline Free of other bias & Low risk & No significant differences between groups reported at baseline \\
\hline
\end{tabular}

\section{Moore 1984}

\begin{tabular}{ll}
\hline Methods & Parallel group RCT \\
& Location: USA/Canada \\
& Funding: PHS grant
\end{tabular}

\begin{tabular}{ll}
\hline Participants & $\begin{array}{l}\text { Inclusion criteria: healthy children aged } 2 \text { to } 5 \text { years who were considered unco-operative and required } \\
\text { treatment under local anaesthesia } \\
\mathrm{n}=60 \\
\text { Gender, mean age in years: } \\
\text { Group } 1(\mathrm{n}=15), 11 \text { male, } 4 \text { female, } 3.6 \\
\text { Group 2 }(\mathrm{n}=15), 7 \text { male, } 8 \text { female, } 3.3 \\
\text { Group 3 }(\mathrm{n}=15), 9 \text { male, } 6 \text { female, } 3.8 \\
\text { Group 4 }(\mathrm{n}=15), 7 \text { male, } 8 \text { female, 3.9 }\end{array}$ \\
\hline Interventions & $\begin{array}{l}\text { Group 1: placebo } \\
\text { Group 3: chloral hydrate }(20 \mathrm{mg} / \mathrm{kg}) \\
\text { Group 4: chloral hydrate }(40 \mathrm{mg} / \mathrm{kg}) \\
\text { All oral, administered by research assistant }\end{array}$ \\
\hline Butcomes & Behaviour evaluations, completion of treatment \\
\hline Notes & 40:60 nitrous oxide/oxygen given to all
\end{tabular}

\section{Risk of bias}

\begin{tabular}{lll}
\hline Bias & Authors' judgement & Support for judgement \\
\hline $\begin{array}{l}\text { Random sequence genera- } \\
\text { tion (selection bias) }\end{array}$ & Unclear risk & "Randomly assigned" - method of sequence generation not described \\
\hline $\begin{array}{l}\text { Allocation concealment } \\
\text { (selection bias) }\end{array}$ & Unclear risk & Not described \\
\hline Blinding - Participant & Low risk & Quote: "double blind conditions" \\
\hline $\begin{array}{l}\text { Blinding - Operator/seda- } \\
\text { tionist }\end{array}$ & Low risk & Quote: "double blind conditions" \\
\hline \hline
\end{tabular}


Moore 1984 (Continued)

$\begin{array}{ll}\begin{array}{l}\text { Blinding - Outcome asses- Low risk } \\ \text { sor }\end{array} & \begin{array}{l}\text { Each child was monitored by a single research assistant, assumed to be blind- } \\ \text { ed to allocated treatment }\end{array}\end{array}$
so

Incomplete outcome as- High risk Numbers evaluated unclear
sessment

\begin{tabular}{lll}
\hline Free of selective reporting & Low risk & All planned outcomes reported \\
\hline Free of other bias & Low risk & No apparent differences between groups at baseline
\end{tabular}

\section{Moreira 2013}

\begin{tabular}{|c|c|}
\hline Methods & $\begin{array}{l}\text { Parallel design } \\
\text { Funding: not stated } \\
\text { Location: Brazil }\end{array}$ \\
\hline Participants & $\begin{array}{l}\text { Inclusion criteria: ASA } 1 \text { presenting with early childhood caries and definitely negative behaviour } \\
n=44 \\
\text { Age range = below } 36 \text { months } \\
\text { Mean age (SD) in months, gender: } \\
\text { Group } 1(n=11), 27.1 \text { (8.3), } 6 \text { males, } 5 \text { females } \\
\text { Group } 2 \text { ( } n=18 \text {, parents refused treatment for } 2), 27.7(5.5), 9 \text { males, } 7 \text { females } \\
\text { Group } 3(n=15 \text {, parents refused treatment for } 1), 27.3(6.4), 9 \text { males, } 5 \text { females }\end{array}$ \\
\hline Interventions & $\begin{array}{l}\text { Group 1: midazolam }(0.5 \mathrm{mg} / \mathrm{kg})+\text { ketamine }(3 \mathrm{mg} / \mathrm{kg}) \\
\text { Group 2: midazolam }(1 \mathrm{mg} / \mathrm{kg}) \\
\text { Group 3: no sedation } \\
\text { Group } 1 \text { and } 2 \text { orally }\end{array}$ \\
\hline
\end{tabular}

Outcomes

Ohio State University Behavior Rating Scale (OSUBRS) reported at individual points or as a sum of all the measurements at individual points added together

\begin{tabular}{lll}
\hline Notes & Protective stabilization used. No placebo given \\
\hline Risk of bias & Authors' judgement & Support for judgement \\
\hline Bias & Quote: "randomized using envelopes" \\
\hline $\begin{array}{l}\text { Random sequence genera- } \\
\text { tion (selection bias) }\end{array}$ & Low risk & $\begin{array}{l}\text { Quotes: "48 opaque sealed envelopes divided equally among the } 3 \text { tech- } \\
\text { niques", "shuffled the envelopes and had her pull } 1 \text { out. After opening the en- } \\
\text { velope, the mother reviewed the insert and the ascertained the child's treat- } \\
\text { ment assignment" }\end{array}$ \\
\hline $\begin{array}{l}\text { Allocation concealment } \\
\text { (selection bias) }\end{array}$ & Low risk & \\
\hline
\end{tabular}


Moreira 2013 (Continued)

Blinding - Participant High risk Quote: "After opening the envelope, the mother reviewed the insert and ascertained the child's treatment assignment"

\begin{tabular}{|c|c|c|}
\hline $\begin{array}{l}\text { Blinding - Operator/seda- } \\
\text { tionist }\end{array}$ & High risk & $\begin{array}{l}\text { Blinding of the operator is unclear, all sedation was carried out by } 1 \text { anaesthe- } \\
\text { siologist and they appear to be unblinded }\end{array}$ \\
\hline $\begin{array}{l}\text { Blinding - Outcome asses- } \\
\text { sor }\end{array}$ & High risk & $\begin{array}{l}\text { Quote: "The behaviour of the children was assessed by } 1 \text { trained, unblinded } \\
\text { observer throughout the dental exam" }\end{array}$ \\
\hline $\begin{array}{l}\text { Incomplete outcome as- } \\
\text { sessment }\end{array}$ & Low risk & All patients and dropouts mentioned \\
\hline Free of selective reporting & Low risk & All planned outcomes reported \\
\hline Free of other bias & High risk & Not clear if Group 3 had a placebo intervention or no intervention at all \\
\hline
\end{tabular}

Mortazavi 2009

\begin{tabular}{|c|c|c|}
\hline \multirow[t]{3}{*}{ Methods } & \multicolumn{2}{|l|}{ Parallel group RCT } \\
\hline & \multicolumn{2}{|l|}{ Location: Iran } \\
\hline & \multicolumn{2}{|c|}{ Funding: university grant } \\
\hline \multirow[t]{3}{*}{ Participants } & \multicolumn{2}{|c|}{ Inclusion criteria: healthy children rate 1 or 2 on Frankl scale requiring dental treatment } \\
\hline & \multicolumn{2}{|l|}{$\mathrm{n}=40$} \\
\hline & \multicolumn{2}{|c|}{ Mean age (SD) in years: $3.99(0.38)$} \\
\hline \multirow[t]{3}{*}{ Interventions } & \multicolumn{2}{|l|}{ Group 1: placebo } \\
\hline & \multicolumn{2}{|c|}{ Group 2: midazolam $(0.25 \mathrm{mg} / \mathrm{kg})$} \\
\hline & \multicolumn{2}{|c|}{ All oral, administered by dental nurse } \\
\hline Outcomes & \multicolumn{2}{|l|}{ Houpt } \\
\hline Notes & \multicolumn{2}{|c|}{ Lack of demographic data } \\
\hline \multicolumn{3}{|l|}{ Risk of bias } \\
\hline Bias & Authors' judgement & Support for judgement \\
\hline $\begin{array}{l}\text { Random sequence genera- } \\
\text { tion (selection bias) }\end{array}$ & Unclear risk & "Randomly given" - method of sequence generation not described \\
\hline $\begin{array}{l}\text { Allocation concealment } \\
\text { (selection bias) }\end{array}$ & Unclear risk & Not described \\
\hline Blinding - Participant & Low risk & Study described as double-blind \\
\hline $\begin{array}{l}\text { Blinding - Operator/seda- } \\
\text { tionist }\end{array}$ & Low risk & Quote: "operator blind to drug used" \\
\hline
\end{tabular}


Mortazavi 2009 (Continued)

\begin{tabular}{lll}
$\begin{array}{l}\text { Blinding - Outcome asses- } \\
\text { sor }\end{array}$ & Low risk & Study described as double-blind - outcomes assessed by "senior investigator" \\
\hline $\begin{array}{l}\text { Incomplete outcome as- } \\
\text { sessment }\end{array}$ & Low risk & All randomised participants included in outcome assessment \\
\hline Free of selective reporting & Low risk & Planned outcomes reported \\
\hline Free of other bias & Unclear risk & Very little information on participant demographics at baseline
\end{tabular}

Nathan 1988

$\begin{array}{ll}\text { Methods } & \text { Parallel group RCT } \\ \text { Location: USA } \\ \text { Funding: university grant }\end{array}$

\begin{tabular}{ll}
\hline Participants & Inclusion criteria: healthy children without previous dental experience requiring 4 restorative treat- \\
ment visits, rated as anxious at screening visit \\
$\mathrm{n}=35$ \\
Age range $=48$ to 72 months
\end{tabular}

\begin{tabular}{ll}
\hline Interventions & Group 1: no intervention \\
& $\begin{array}{l}\text { Group 2: placebo inhalation (oxygen) } \\
\text { Group 3: 20-50:50 nitrous oxide/oxygen } \\
\text { Inhalation, all administered by anaesthetist }\end{array}$ \\
\hline Outcomes & Venham scale, parental questionnaire, behavioural screening instrument \\
\hline Notes & Dr Nathan was contacted to clarify the blinding in this trial and to enquire about any unpublished trials
\end{tabular}

\section{Risk of bias}

Bias Authors' judgement Support for judgement

Random sequence genera- Unclear risk "Randomly assigned" - method of sequence generation not described tion (selection bias)

\begin{tabular}{lll}
\hline $\begin{array}{l}\text { Allocation concealment } \\
\text { (selection bias) }\end{array}$ & Unclear risk & Not described \\
\hline Blinding - Participant & Unclear risk & Study described as double-blind. This only applies to Group 2 and Group 3 \\
\hline $\begin{array}{l}\text { Blinding - Operator/seda- } \\
\text { tionist }\end{array}$ & Unclear risk & Study described as double-blind. This only applies to Group 2 and Group 3 \\
\hline $\begin{array}{l}\text { Blinding - Outcome asses- } \\
\text { sor }\end{array}$ & Low risk & $\begin{array}{l}\text { Ratings of unco-operative behaviour and anxiety were made by trained judges } \\
\text { naive to experimental hypotheses and inhalant conditions }\end{array}$ \\
\hline $\begin{array}{l}\text { Incomplete outcome as- } \\
\text { sessment }\end{array}$ & Unclear risk & Numbers included/dropouts unclear \\
\hline \begin{tabular}{l} 
Free of selective reporting \\
\hline
\end{tabular} & Low risk & All planned outcomes reported \\
\hline
\end{tabular}


Nathan 1988 (Continued)

Free of other bias High risk No information on demographic characteristics at baseline

Park 2006

\begin{tabular}{|c|c|}
\hline Methods & $\begin{array}{l}\text { Parallel } \\
\text { Location: South Korea } \\
\text { Funding: not stated }\end{array}$ \\
\hline Participants & $\begin{array}{l}\text { Inclusion criteria: ASA I, under } 6 \text { years, } 20 \text { kg body weight, unco-operative requiring sedation for dental } \\
\text { treatment } \\
\text { Mean age in months (SD), gender, mean weight in } \mathrm{kg}(\mathrm{SD}) \text { : } \\
\text { Group } 1 \text { ( } \mathrm{n}=15), 44.5(14.1), 6 \text { males and } 9 \text { females, } 15.6(2.7) \\
\text { Group } 2(\mathrm{n}=16), 34.3(9.3), 11 \text { males and } 5 \text { females, } 15.1(2.6)\end{array}$ \\
\hline Interventions & $\begin{array}{l}\text { Group 1: chloral hydrate }(60 \mathrm{mg} / \mathrm{kg})+\text { hydroxyzine }(1 \mathrm{mg} / \mathrm{kg}) \text {. Both oral } \\
\text { Group 2: chloral hydrate }(60 \mathrm{mg} / \mathrm{kg}) \text { (oral) + hydroxyzine }(1 \mathrm{mg} / \mathrm{kg}) \text { (oral) + midazolam }(0.1 \mathrm{mg} / \mathrm{kg}) \text { (sub- } \\
\text { mucosal) } \\
\text { Administered by dentist }\end{array}$ \\
\hline Outcomes & Houpt, requirement for restraint \\
\hline Notes & $50 \%$ nitrous oxide/oxygen administered to all \\
\hline
\end{tabular}

Risk of bias

\begin{tabular}{lll}
\hline Bias & Authors' judgement & Support for judgement \\
\hline $\begin{array}{l}\text { Random sequence genera- } \\
\text { tion (selection bias) }\end{array}$ & Unclear risk & Not described \\
\hline $\begin{array}{l}\text { Allocation concealment } \\
\text { (selection bias) }\end{array}$ & Unclear risk & Not described \\
\hline Blinding - Participant & High risk & Not blinded \\
\hline $\begin{array}{l}\text { Blinding - Operator/seda- } \\
\text { tionist }\end{array}$ & High risk & Not blinded \\
\hline $\begin{array}{l}\text { Blinding - Outcome asses- } \\
\text { sor }\end{array}$ & Low risk & Video used, assessor blinded \\
\hline $\begin{array}{l}\text { Incomplete outcome as- } \\
\text { sessment }\end{array}$ & Low risk & All outcomes reported \\
\hline $\begin{array}{l}\text { Free of selective reporting } \\
\text { Free of other bias }\end{array}$ & Low risk & Low risk \\
\hline
\end{tabular}


Rai 2007

\begin{tabular}{|c|c|c|}
\hline \multirow[t]{3}{*}{ Methods } & \multicolumn{2}{|l|}{ Parallel group RCT } \\
\hline & \multicolumn{2}{|l|}{ Location: India } \\
\hline & \multicolumn{2}{|l|}{ Funding: not stated } \\
\hline Participants & \multicolumn{2}{|c|}{$\begin{array}{l}\text { Inclusion criteria: healthy, unco-operative, anxious and apprehensive children requiring oral prophy- } \\
\text { laxis/fluoride gel/restorations/extractions/composite fillings/pulp therapies }\end{array}$} \\
\hline & \multicolumn{2}{|l|}{$\mathrm{n}=30$ (10 per group) } \\
\hline & \multicolumn{2}{|l|}{ Age range: 3 to 6 years } \\
\hline \multirow[t]{5}{*}{ Interventions } & \multicolumn{2}{|c|}{ Group 1: midazolam $(0.1 \mathrm{mg} / \mathrm{kg}$ ) (bolus) $+0.004 \mathrm{mg} / \mathrm{kg} / \mathrm{min}$ infusion } \\
\hline & \multicolumn{2}{|c|}{ Group 2: propofol (1 mg/kg) (bolus) $+0.06 \mathrm{mg} / \mathrm{kg} / \mathrm{min}$ infusion } \\
\hline & \multicolumn{2}{|c|}{ Group 3: ketamine $(0.5 \mathrm{mg} / \mathrm{kg})$ (bolus) $+0.01 \mathrm{mg} / \mathrm{kg} / \mathrm{min}$ infusion } \\
\hline & \multicolumn{2}{|l|}{ All intravenous } \\
\hline & \multicolumn{2}{|c|}{$\begin{array}{l}\text { All children had premedication } 1 \text { hour before, comprising } 0.5 \mathrm{mg} / \mathrm{kg} \text { midazolam and atropine }(0.6 \mathrm{mg}) \text {, } \\
\text { all drugs administered by anaesthetist }\end{array}$} \\
\hline Outcomes & \multicolumn{2}{|l|}{ Houpt } \\
\hline \multicolumn{3}{|l|}{ Notes } \\
\hline \multicolumn{3}{|l|}{ Risk of bias } \\
\hline Bias & Authors' judgement & Support for judgement \\
\hline $\begin{array}{l}\text { Random sequence genera- } \\
\text { tion (selection bias) }\end{array}$ & Unclear risk & "Randomly divided" - method of sequence generation not described \\
\hline $\begin{array}{l}\text { Allocation concealment } \\
\text { (selection bias) }\end{array}$ & Unclear risk & Not described \\
\hline Blinding - Participant & Unclear risk & Not described \\
\hline $\begin{array}{l}\text { Blinding - Operator/seda- } \\
\text { tionist }\end{array}$ & Unclear risk & Not described \\
\hline $\begin{array}{l}\text { Blinding - Outcome asses- } \\
\text { sor }\end{array}$ & Unclear risk & Not described \\
\hline $\begin{array}{l}\text { Incomplete outcome as- } \\
\text { sessment }\end{array}$ & High risk & Numbers evaluated not stated \\
\hline Free of selective reporting & Low risk & All planned outcomes reported \\
\hline Free of other bias & Unclear risk & Very little information on participant demographics at baseline \\
\hline
\end{tabular}

Reeves 1996

Methods Parallel group RCT


Reeves 1996 (Continued)

Location: USA

Funding: not stated

\begin{tabular}{|c|c|c|}
\hline Participants & \multicolumn{2}{|c|}{$\begin{array}{l}\text { Inclusion criteria: healthy children aged } 27 \text { to } 73 \text { months, definitely negative behaviour on Frankl scale } \\
n=40 \\
\text { Gender, mean age (age range) in months: } \\
\text { Group } 1(\mathrm{n}=20), 11 \text { male, } 9 \text { female, } 48 \text { ( } 32 \text { to } 73) \\
\text { Group } 2(n=20), 10 \text { male, } 10 \text { female, } 42(27 \text { to } 70)\end{array}$} \\
\hline Interventions & \multicolumn{2}{|c|}{$\begin{array}{l}\text { Group 1: chloral hydrate }(50 \mathrm{mg} / \mathrm{kg})+\text { hydroxyzine }(25 \mathrm{mg}) \\
\text { Group 2: midazolam }(0.5 \mathrm{mg} / \mathrm{kg})+\text { acetaminophen }(10 \mathrm{mg} / \mathrm{kg}) \\
\text { All oral, administered by paediatric dentist not involved in study }\end{array}$} \\
\hline Outcomes & \multicolumn{2}{|l|}{ Modified Houpt } \\
\hline Notes & \multicolumn{2}{|l|}{ Papoose board } \\
\hline \multicolumn{3}{|l|}{ Risk of bias } \\
\hline Bias & Authors' judgement & Support for judgement \\
\hline $\begin{array}{l}\text { Random sequence genera- } \\
\text { tion (selection bias) }\end{array}$ & Unclear risk & $\begin{array}{l}\text { "Patients were assigned randomly" - method of sequence generation not de- } \\
\text { scribed }\end{array}$ \\
\hline $\begin{array}{l}\text { Allocation concealment } \\
\text { (selection bias) }\end{array}$ & Unclear risk & Not described \\
\hline Blinding - Participant & Low risk & Study described as double-blind \\
\hline $\begin{array}{l}\text { Blinding - Operator/seda- } \\
\text { tionist }\end{array}$ & Low risk & Study described as double-blind \\
\hline $\begin{array}{l}\text { Blinding - Outcome asses- } \\
\text { sor }\end{array}$ & Low risk & Outcomes were evaluated by primary operator and 1 observer \\
\hline $\begin{array}{l}\text { Incomplete outcome as- } \\
\text { sessment }\end{array}$ & High risk & Numbers evaluated not stated \\
\hline Free of selective reporting & Low risk & All planned outcomes reported \\
\hline Free of other bias & Low risk & No apparent differences between groups at baseline \\
\hline
\end{tabular}

Roelofse 1996a

\begin{tabular}{ll}
\hline Methods & Parallel group RCT \\
& Location: South Africa \\
& Funding: not stated \\
\hline Participants & Inclusion criteria: unco-operative children \\
& $\mathrm{n}=100$ \\
& Gender, mean age (SD) in years: \\
& Group $1(\mathrm{n}=50), 24$ male, 26 female, $4.3(1)$ \\
& Group 2 $(\mathrm{n}=50), 22$ male, 28 female, $4.3(1.1)$
\end{tabular}


Roelofse 1996a (Continued)

Interventions
Group 1: ketamine $(5 \mathrm{mg} / \mathrm{kg})+$ midazolam $(0.35 \mathrm{mg} / \mathrm{kg})$

Group 2: midazolam (1 mg/kg)

All rectal, administered by member of research team

Outcomes Ramsay Sedation Score, movement, crying, overall sedation and behaviour

\section{Notes}

\section{Risk of bias}

\begin{tabular}{|c|c|c|}
\hline Bias & Authors' judgement & Support for judgement \\
\hline $\begin{array}{l}\text { Random sequence genera- } \\
\text { tion (selection bias) }\end{array}$ & Unclear risk & "Randomly assigned" - method of sequence generation not described \\
\hline $\begin{array}{l}\text { Allocation concealment } \\
\text { (selection bias) }\end{array}$ & Unclear risk & Not described \\
\hline Blinding - Participant & Low risk & Study described as double-blind \\
\hline $\begin{array}{l}\text { Blinding - Operator/seda- } \\
\text { tionist }\end{array}$ & Low risk & Study described as double-blind \\
\hline $\begin{array}{l}\text { Blinding - Outcome asses- } \\
\text { sor }\end{array}$ & Low risk & Quote: "Anxiety was scored by an independent observer" \\
\hline $\begin{array}{l}\text { Incomplete outcome as- } \\
\text { sessment }\end{array}$ & High risk & Numbers evaluated not stated \\
\hline Free of selective reporting & Low risk & All planned outcomes reported \\
\hline Free of other bias & Low risk & No apparent differences between groups at baseline \\
\hline
\end{tabular}

\section{Roelofse 1996b}

\begin{tabular}{ll}
\hline Methods & Parallel group RCT \\
& Location: South Africa \\
& Funding: not stated
\end{tabular}

Participants
Inclusion criteria: children ASA I aged 2 to 7 years old, requiring dental extraction under sedation
$\mathrm{n}=60$
Gender, mean age $(S D)$ in years:
Group $1(\mathrm{n}=30), 14$ male, 16 female, $4.8(1.3)$
Group $2(\mathrm{n}=30), 16$ male, 14 female, $4.9(1.3)$

Group $2(\mathrm{n}=30), 16$ male, 14 female, $4.9(1.3)$

$\begin{array}{ll}\text { Interventions } & \text { Group 1: } 0.5 \mathrm{ml} / \mathrm{kg} \text { of trimeprazine } 6 \mathrm{mg} / \mathrm{ml}+\text { physeptone }(0.4 \mathrm{mg} / \mathrm{ml})(\mathrm{SOP}) \\ \text { Group 2: ketamine }(12.5 \mathrm{mg} / \mathrm{kg}) \\ \text { All oral, administered by a member of the research team not the operator }\end{array}$

Outcomes Anxiety, level of sedation, movement, crying, overall behaviour

\section{Notes}


Roelofse 1996b (Continued)

\section{Risk of bias}

\begin{tabular}{|c|c|c|}
\hline Bias & Authors' judgement & Support for judgement \\
\hline $\begin{array}{l}\text { Random sequence genera- } \\
\text { tion (selection bias) }\end{array}$ & Unclear risk & "Assigned randomly" - method of sequence generation not described \\
\hline $\begin{array}{l}\text { Allocation concealment } \\
\text { (selection bias) }\end{array}$ & Unclear risk & Not described \\
\hline Blinding - Participant & Low risk & Study described as double-blind \\
\hline $\begin{array}{l}\text { Blinding - Operator/seda- } \\
\text { tionist }\end{array}$ & Low risk & Quote: "both operator and assessor blind to treatment received" \\
\hline $\begin{array}{l}\text { Blinding - Outcome asses- } \\
\text { sor }\end{array}$ & Low risk & Quote: "both operator and assessor blind to treatment received" \\
\hline $\begin{array}{l}\text { Incomplete outcome as- } \\
\text { sessment }\end{array}$ & High risk & Numbers evaluated not stated \\
\hline Free of selective reporting & Low risk & All planned outcomes reported \\
\hline Free of other bias & Low risk & No apparent differences between groups at baseline \\
\hline
\end{tabular}

\section{Roelofse 1998}

$\begin{array}{ll}\text { Methods } & \text { Parallel group RCT } \\ & \text { Location: South Africa } \\ & \text { Funding: not stated }\end{array}$

Participants
\[ \begin{array}{l}\text { Inclusion criteria: children ASA I aged } 2 \text { to } 7 \text { years, randomly selected from dental clinic } \\ \text { Gender, mean age (SD) in years: } \\ \text { Group } 1(\mathrm{n}=50), 27 \text { male, } 23 \text { female, } 4.1(1.3) \\ \text { Group } 2(\mathrm{n}=50), 29 \text { male, } 21 \text { female, } 4(1.2)\end{array} \]

Interventions Group 1: ketamine $(5 \mathrm{mg} / \mathrm{kg})+$ midazolam $(0.35 \mathrm{mg} / \mathrm{kg})$

Group 2: trimeprazine $(3 \mathrm{mg} / \mathrm{kg})+$ methadone $(0.2 \mathrm{mg} / \mathrm{kg})$

All oral

Outcomes Modified Houpt, Ramsay Sedation Score

$$
\text { Notes }
$$

\section{Risk of bias}

\begin{tabular}{lll}
\hline Bias & Authors' judgement & Support for judgement \\
\hline $\begin{array}{l}\text { Random sequence genera- } \\
\text { tion (selection bias) }\end{array}$ & Unclear risk & "Randomly selected" - method of sequence generation not described \\
\hline
\end{tabular}


Roelofse 1998 (Continued)

\begin{tabular}{|c|c|c|}
\hline $\begin{array}{l}\text { Allocation concealment } \\
\text { (selection bias) }\end{array}$ & Unclear risk & Not described \\
\hline Blinding - Participant & High risk & Not reported as being blinded \\
\hline $\begin{array}{l}\text { Blinding - Operator/seda- } \\
\text { tionist }\end{array}$ & Low risk & Operator blinded to the treatment regimen \\
\hline $\begin{array}{l}\text { Blinding - Outcome asses- } \\
\text { sor }\end{array}$ & Low risk & Operator evaluated the sedation \\
\hline $\begin{array}{l}\text { Incomplete outcome as- } \\
\text { sessment }\end{array}$ & High risk & Numbers evaluated not stated \\
\hline Free of selective reporting & Low risk & All planned outcomes reported \\
\hline Free of other bias & Low risk & No apparent differences between groups at baseline \\
\hline
\end{tabular}

\section{Sams 1993a}

\begin{tabular}{|c|c|}
\hline \multirow[t]{3}{*}{ Methods } & Parallel group RCT \\
\hline & Location:USA \\
\hline & Funding: not stated \\
\hline Participants & $\begin{array}{l}\text { Inclusion criteria: children ASA I with no prior sedation experience, needing }>2 \text { restorations, with Fran- } \\
\text { kl score } 1 \text { (definitely negative behaviour) } \\
n=24 \\
\text { Mean age }(S D) \text { in months: } \\
\text { Group } 1(n=13), 31.0(8.6) \\
\text { Group } 2(n=11), 35.8(10.6)\end{array}$ \\
\hline Interventions & $\begin{array}{l}\text { Group 1: chloral hydrate }(50 \mathrm{mg} / \mathrm{kg})+\text { promethazine }(1 \mathrm{mg} / \mathrm{kg}) \\
\text { Group 2: meperidine }(1 \mathrm{mg} / \mathrm{kg})+\text { promethazine }(1 \mathrm{mg} / \mathrm{kg}) \\
\text { All oral, sedation administered by principal investigator or attending faculty member }\end{array}$ \\
\hline Outcomes & Modified Houpt \\
\hline Notes & $\begin{array}{l}\text { Papoose board } \\
\text { Nitrous oxide/oxygen where indicated }\end{array}$ \\
\hline
\end{tabular}

\section{Risk of bias}

Bias Authors' judgement Support for judgement

Random sequence genera- Unclear risk "Assigned randomly" - method of sequence generation not described tion (selection bias)

\begin{tabular}{lll}
\hline $\begin{array}{l}\text { Allocation concealment } \\
\text { (selection bias) }\end{array}$ & Unclear risk & Not described \\
\hline Blinding - Participant & Low risk & Study described as double-blind \\
\hline
\end{tabular}


Sams 1993a (Continued)

\begin{tabular}{lll}
$\begin{array}{l}\text { Blinding - Operator/seda- } \\
\text { tionist }\end{array}$ & Low risk & Study described as double-blind \\
\hline $\begin{array}{l}\text { Blinding - Outcome asses- } \\
\text { sor }\end{array}$ & Low risk & Operators, who were blinded to allocated treatment, assessed outcomes \\
\hline $\begin{array}{l}\text { Incomplete outcome as- } \\
\text { sessment }\end{array}$ & High risk & All planned outcomes reported \\
\hline $\begin{array}{l}\text { Free of selective reporting } \\
\text { Free of other bias }\end{array}$ & Low risk & No apparent differences between groups at baseline
\end{tabular}

Shanmugaavel 2016a

\begin{tabular}{ll}
\hline Methods & Parallel design RCT \\
& Funding: not stated \\
& Location: India \\
\hline Participants & $\begin{array}{l}\text { Inclusion criteria: ASA 1 and 2. Venham's clinical anxiety scale score } \geq 3 \text { during first visit and required } \\
\text { treatment under local anaesthesia }\end{array}$ \\
& $\mathrm{n}=20$ \\
& Age range $=4$ to 7 years \\
& Group 1 ( $\mathrm{n}=10)$ \\
& Group 2 ( $\mathrm{n}=10)$ \\
\hline Interventions & Group $1:$ midazolam $(0.2 \mathrm{mg} / \mathrm{kg}$ ) (intranasal) \\
& Group 2: midazolam $(0.2 \mathrm{mg} / \mathrm{kg})$ (sublingual) \\
\hline Outcomes & Venham's clinical anxiety scale, salivary cortisol level \\
\hline Notes & Procedure was videotaped, restraints were used \\
\hline
\end{tabular}

\section{Risk of bias}

\begin{tabular}{lll}
\hline Bias & Authors' judgement & Support for judgement \\
\hline $\begin{array}{l}\text { Random sequence genera- } \\
\text { tion (selection bias) }\end{array}$ & Low risk & Quote: "randomization pattern generated by computer software" \\
\hline $\begin{array}{l}\text { Allocation concealment } \\
\text { (selection bias) }\end{array}$ & Unclear risk & Not described \\
\hline Blinding - Participant & Unclear risk & Not described \\
\hline $\begin{array}{l}\text { Blinding - Operator/seda- } \\
\text { tionist }\end{array}$ & Low risk & Quote: "single operator blinded to routes of drug administration" \\
\hline $\begin{array}{l}\text { Blinding - Outcome asses- } \\
\text { sor }\end{array}$ & Unclear risk & Not described \\
\hline \hline
\end{tabular}


Shanmugaavel 2016a (Continued)

Incomplete outcome as- High risk Number of sedation failure not recorded
sessment

\begin{tabular}{lll}
\hline Free of selective reporting & Low risk & All planned outcomes reported \\
\hline Free of other bias & High risk & Sample demographics not explained \\
\hline
\end{tabular}

Shanmugaavel 2016b

\begin{tabular}{ll}
\hline Methods & Parallel group RCT \\
Location: India \\
Funding: not stated
\end{tabular}

Participants Inclusion criteria: ASA 1 and 2. Venham's clinical anxiety scale score $\geq 2$ during first visit and required treatment under local anaesthesia

$n=40$

Mean age (SD) in years, gender, weight (SD) in $\mathrm{kg}$ :

Group A: 5.1 (1.07), 12 males and 8 females, 17.5 (4.39)

Group B: 5.2 (1.15), 12 males and 8 females, 17.4 (4.33)

\begin{tabular}{ll}
\hline Interventions & Group A: midazolam $(0.2 \mathrm{mg} / \mathrm{kg})$ (intranasal) \\
& Group B: midazolam $(0.2 \mathrm{mg} / \mathrm{kg})$ (sublingual) \\
\hline Outcomes & Anxiety (Venham scale), acceptance \\
\hline Notes & No apparent differences between groups at baseline \\
\hline
\end{tabular}

\section{Risk of bias}

\begin{tabular}{lll}
\hline Bias & Authors' judgement & Support for judgement \\
\hline $\begin{array}{l}\text { Random sequence genera- } \\
\text { tion (selection bias) }\end{array}$ & Low risk & Excel used \\
\hline $\begin{array}{l}\text { Allocation concealment } \\
\text { (selection bias) }\end{array}$ & Unclear risk & Not described \\
\hline Blinding - Participant & High risk & Not blinded (not possible) \\
\hline $\begin{array}{l}\text { Blinding - Operator/seda- } \\
\text { tionist }\end{array}$ & High risk & Not blinded \\
\hline $\begin{array}{l}\text { Blinding - Outcome asses- } \\
\text { sor }\end{array}$ & Low risk & Video used \\
\hline $\begin{array}{l}\text { Incomplete outcome as- } \\
\text { sessment }\end{array}$ & Low risk & All outcomes assessed \\
\hline \begin{tabular}{l} 
Free of selective reporting \\
\hline
\end{tabular} & Low risk & Dropouts reported \\
\hline
\end{tabular}


Shanmugaavel 2016b (Continued)
Free of other bias
Low risk
No other bias

Shashikiran 2006

\begin{tabular}{|c|c|c|}
\hline \multirow[t]{3}{*}{ Methods } & \multicolumn{2}{|l|}{ Parallel group RCT } \\
\hline & \multicolumn{2}{|l|}{ Location: India } \\
\hline & \multicolumn{2}{|l|}{ Funding: not stated } \\
\hline \multirow[t]{3}{*}{ Participants } & \multicolumn{2}{|l|}{$n=40$} \\
\hline & \multicolumn{2}{|c|}{ Group 1 (11 males, 9 females), mean age 3.4 years $(S D=0.6)$, mean weight $12.2 \mathrm{~kg}(S D=1.2)$} \\
\hline & \multicolumn{2}{|c|}{ Group 2 ( 8 males, 12 females), mean age 3.5 years $(S D=0.7)$, mean weight $12.6 \mathrm{~kg}(S D=1.4)$} \\
\hline \multirow[t]{2}{*}{ Interventions } & \multicolumn{2}{|c|}{ Group $1(\mathrm{n}=20):$ midazolam $(0.2 \mathrm{mg} / \mathrm{kg}$ ) (intramuscular) } \\
\hline & \multicolumn{2}{|c|}{ Group 2 ( $\mathrm{n}=20):$ midazolam $(0.2 \mathrm{mg} / \mathrm{kg})$ (intranasal) } \\
\hline Outcomes & \multicolumn{2}{|l|}{ Houpt, Fukuta scales } \\
\hline \multicolumn{3}{|l|}{ Notes } \\
\hline \multicolumn{3}{|l|}{ Risk of bias } \\
\hline Bias & Authors' judgement & Support for judgement \\
\hline $\begin{array}{l}\text { Random sequence genera- } \\
\text { tion (selection bias) }\end{array}$ & Unclear risk & "Randomly allocated" - method of sequence generation not described \\
\hline $\begin{array}{l}\text { Allocation concealment } \\
\text { (selection bias) }\end{array}$ & Unclear risk & Not described \\
\hline Blinding - Participant & High risk & Not blinded \\
\hline $\begin{array}{l}\text { Blinding - Operator/seda- } \\
\text { tionist }\end{array}$ & Low risk & Operator blinded to route of administration \\
\hline $\begin{array}{l}\text { Blinding - Outcome asses- } \\
\text { sor }\end{array}$ & Low risk & Outcomes assessed by operator \\
\hline $\begin{array}{l}\text { Incomplete outcome as- } \\
\text { sessment }\end{array}$ & Low risk & All randomised participants included in outcome evaluation \\
\hline Free of selective reporting & Low risk & All planned outcomes reported \\
\hline Free of other bias & Low risk & No apparent differences between groups at baseline \\
\hline
\end{tabular}

Singh 2002

$\begin{array}{ll}\text { Methods } & \text { Parallel group RCT } \\ & \text { Location: India }\end{array}$


Singh 2002 (Continued)

Funding: not stated

\begin{tabular}{|c|c|c|}
\hline Participants & \multicolumn{2}{|c|}{$\begin{array}{l}\text { Inclusion criteria: healthy children ASA I referred for short dental procedures } \\
\mathrm{n}=90 \text { ( } 30 \text { per group) } \\
\text { Age range: } 3 \text { to } 9 \text { years }\end{array}$} \\
\hline Interventions & \multicolumn{2}{|c|}{$\begin{array}{l}\text { Group 1: midazolam }(0.5 \mathrm{mg} / \mathrm{kg}) \\
\text { Group 2: triclofos }(70 \mathrm{mg} / \mathrm{kg}) \\
\text { Group 3: promethazine }(1.2 \mathrm{mg} / \mathrm{kg}) \\
\text { All orally }\end{array}$} \\
\hline Outcomes & \multicolumn{2}{|c|}{ Sedation score, treatment completion } \\
\hline \multicolumn{3}{|l|}{ Notes } \\
\hline \multicolumn{3}{|l|}{ Risk of bias } \\
\hline Bias & Authors' judgement & Support for judgement \\
\hline $\begin{array}{l}\text { Random sequence genera- } \\
\text { tion (selection bias) }\end{array}$ & Unclear risk & "Patients were randomised" - method of sequence generation not described \\
\hline $\begin{array}{l}\text { Allocation concealment } \\
\text { (selection bias) }\end{array}$ & Unclear risk & Not described \\
\hline Blinding - Participant & Low risk & Study described as double-blind \\
\hline $\begin{array}{l}\text { Blinding - Operator/seda- } \\
\text { tionist }\end{array}$ & Low risk & Study described as double-blind \\
\hline $\begin{array}{l}\text { Blinding - Outcome asses- } \\
\text { sor }\end{array}$ & Low risk & Study described as double-blind \\
\hline $\begin{array}{l}\text { Incomplete outcome as- } \\
\text { sessment }\end{array}$ & High risk & Numbers evaluated not stated \\
\hline Free of selective reporting & Low risk & All selected variables reported \\
\hline Free of other bias & Unclear risk & Little information on participants in each group at baseline \\
\hline
\end{tabular}

Singh 2014

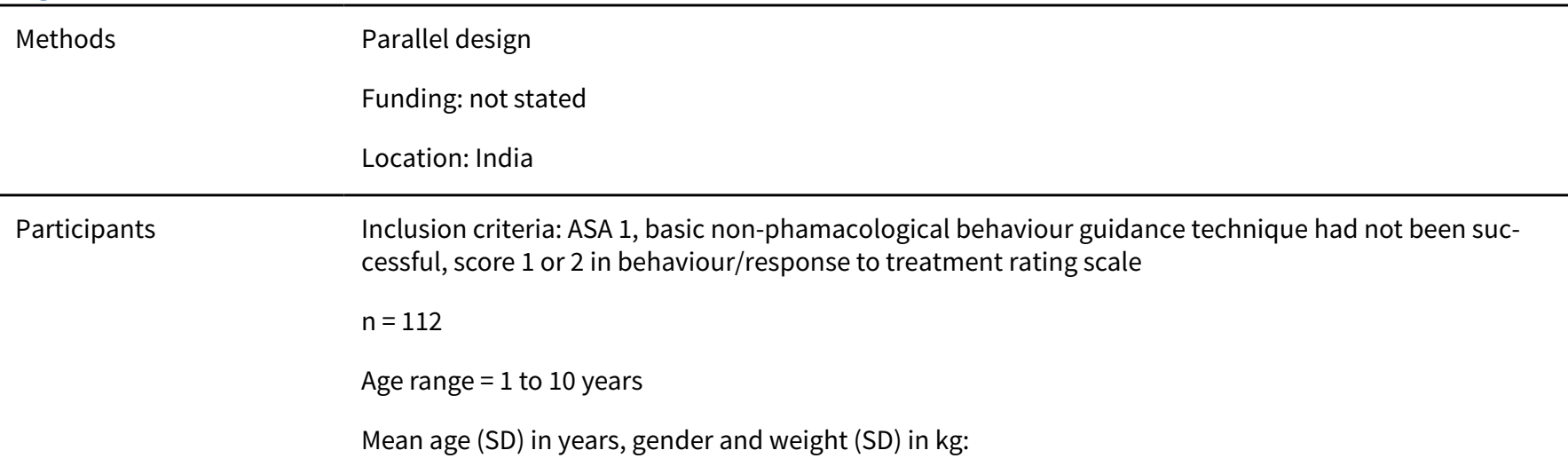


Singh 2014 (Continued)

Group $1(n=28), 6.54$ (1.79), 14 males and 14 females, 18.89 (4.33)

Group $2(n=28), 6.93$ (2.05), 13 males and 15 females, 17.04 (5.33)

Group 3 ( $n=28), 7.21$ (1.98), 11 males and 17 females, 16.93 (4.22)

Group 4 ( $n=28), 6.82$ (2.22), 14 males and 14 females, 16.61 (4.92)

Interventions $\quad$ Group 1: ketamine $\left(8 \mathrm{mg} / \mathrm{kg}^{-1}\right)$
Group 2: dexmedetomidine $\left(3 \mu \mathrm{g} / \mathrm{kg}^{-1}\right)$
Group 3: dexmedetomidine $\left(4 \mu \mathrm{g} / \mathrm{kg}^{-1}\right)$
Group 4: dexmedetomidine $\left(5 \mu \mathrm{g} / \mathrm{kg}^{-1}\right)$

Outcomes

Onset time, recovery time, sedation rating scale modified from AAPD guidelines, Face, Legs, Activity, Cry and Consolability Pain Scale, anterograde amnesia, behaviour score

Notes

\section{Risk of bias}

\begin{tabular}{|c|c|c|}
\hline Bias & Authors' judgement & Support for judgement \\
\hline $\begin{array}{l}\text { Random sequence genera- } \\
\text { tion (selection bias) }\end{array}$ & Low risk & Quote: "randomized according to computer-generated random number list" \\
\hline $\begin{array}{l}\text { Allocation concealment } \\
\text { (selection bias) }\end{array}$ & Low risk & $\begin{array}{l}\text { Quote: "The professor of pharmacology was then informed about weight of } \\
\text { the patient to enable him prepare the coded solutions of the drugs on the day } \\
\text { of treatment" }\end{array}$ \\
\hline Blinding - Participant & Low risk & Described as '"triple-blind" \\
\hline $\begin{array}{l}\text { Blinding - Operator/seda- } \\
\text { tionist }\end{array}$ & Low risk & $\begin{array}{l}\text { Quote: "the principal investigator (PI) obtained the drug solution having same } \\
\text { volume ( } 10 \mathrm{ml} \text { ) and the same colour in a transparent disposable container for } \\
\text { every patient, without knowing the drug ingredient in it" }\end{array}$ \\
\hline $\begin{array}{l}\text { Blinding - Outcome asses- } \\
\text { sor }\end{array}$ & Low risk & $\begin{array}{l}\text { PI was the outcome assessor and the operator sedationist. PI was not aware of } \\
\text { the drug administered }\end{array}$ \\
\hline $\begin{array}{l}\text { Incomplete outcome as- } \\
\text { sessment }\end{array}$ & Low risk & All participants included in the outcome evaluation \\
\hline Free of selective reporting & Low risk & All planned outcomes reported \\
\hline Free of other bias & Low risk & No other bias \\
\hline
\end{tabular}

Somri 2012

\begin{tabular}{ll}
\hline Methods & Parallel design \\
& Funding: not stated \\
& Location: Israel \\
\hline Participants & $\begin{array}{l}\text { Inclusion criteria: patients unable to tolerate dental treatment under behavioural management and lo- } \\
\text { cal anaesthetic or in combination with nitrous oxide use }\end{array}$ \\
\hline
\end{tabular}


Somri 2012 (Continued)

$$
\begin{aligned}
& \mathrm{n}=90 \\
& \text { Age range }=3 \text { to } 10 \text { years } \\
& \text { Mean age }(\mathrm{SD}) \text { in years, weight }(\mathrm{SD}) \text { in } \mathrm{kg} \text { : } \\
& \text { Group 1: } 5.6 \pm 1.85,19.2 \pm 3.68 \\
& \text { Group 2: } 5.6 \pm 1.67,19.7 \pm 3.38 \\
& \text { Group 3: } 6.2 \pm 2.00,20.3 \pm 3.65
\end{aligned}
$$

\begin{tabular}{|c|c|c|}
\hline Bias & Authors' judgement & Support for judgement \\
\hline $\begin{array}{l}\text { Random sequence genera- } \\
\text { tion (selection bias) }\end{array}$ & Low risk & Quote: "randomly assigned by sealed envelope technique" \\
\hline $\begin{array}{l}\text { Allocation concealment } \\
\text { (selection bias) }\end{array}$ & Unclear risk & Not described \\
\hline Blinding - Participant & Unclear risk & Not described \\
\hline $\begin{array}{l}\text { Blinding - Operator/seda- } \\
\text { tionist }\end{array}$ & Low risk & $\begin{array}{l}\text { Nursing staff administering the midazolam, specialist paediatric dentist and } \\
\text { anaesthetist performing procedure and post-operative discharge nurses were } \\
\text { blinded }\end{array}$ \\
\hline $\begin{array}{l}\text { Blinding - Outcome asses- } \\
\text { sor }\end{array}$ & Unclear risk & Not described if the assessor was blinded \\
\hline $\begin{array}{l}\text { Incomplete outcome as- } \\
\text { sessment }\end{array}$ & Low risk & All participants included in the outcome evaluation \\
\hline Free of selective reporting & Low risk & All planned outcomes reported \\
\hline Free of other bias & Low risk & No other bias \\
\hline
\end{tabular}

\begin{tabular}{ll}
\hline Interventions & Group 1: midazolam $(0.5 \mathrm{mg} / \mathrm{kg})$ \\
& Group 2: midazolam $(0.75 \mathrm{mg} / \mathrm{kg})$ \\
& Group 3: midazolam $(1 \mathrm{mg} / \mathrm{kg})$ \\
& All orally \\
\hline Outcomes & Wisconsin sedation scale, Houpt behavioural rating scale, parent satisfaction \\
\hline Notes & Immobilisation with manual restraining used \\
& Wisconsin level 5 (deep sedation) considered adequate \\
All children received 2 litres of oxygen during treatment
\end{tabular}

\section{Risk of bias}

Surendar 2014

$\begin{array}{ll}\text { Methods } & \text { Parallel design RCT } \\ & \text { Funding: not stated }\end{array}$


Surendar 2014 (Continued)

Location: India

Participants

Inclusion criteria: ASA 1, fearful/anxious and for whom basic behaviour guidance techniques had not been successful in rendering dental treatment, without any history of previous dental treatment under sedation or anaesthesia and whose treatment necessitated the administration of local anaesthesia

$\mathrm{n}=84$ (43 males, 41 females)

Age range $=4$ to 14 years, weight range $=9$ to $27 \mathrm{~kg}$

Age range in years, mean age (SD) in years, weight (SD) in $\mathrm{kg}$ :

Group $1: 4$ to $12,7.34 \pm 2.34,18.29 \pm 3.04$

Group 2: 4 to $11,6.71 \pm 2.31,16.52 \pm 3.87$

Group 3: 4 to $11,7.76 \pm 2.26,18.57 \pm 4.17$

Group 4: 4 to $11,7.24 \pm 2.36,17.71 \pm 5.36$

\begin{tabular}{ll}
\hline Interventions & Group 1: dexmedetomidine $(1 \mu \mathrm{g} / \mathrm{kg})$ \\
& Group 2: dexmedetomidine $(1.5 \mu \mathrm{g} / \mathrm{kg})$ \\
& Group 3: midazolam $(0.2 \mathrm{mg} / \mathrm{kg})$ \\
& Group 4: ketamine $(5 \mathrm{mg} / \mathrm{kg})$ \\
& All intranasal
\end{tabular}

Outcomes

Modified AAPD sedation record; behaviour/response to treatment rating scale; Face, Legs, Activity, Cry and Consolability (FLACC) scale

\begin{tabular}{|c|c|c|}
\hline Notes & Sedation was conside & d unsuccessful if use of physical restraint during the procedure was required \\
\hline \multicolumn{3}{|l|}{ Risk of bias } \\
\hline Bias & Authors' judgement & Support for judgement \\
\hline $\begin{array}{l}\text { Random sequence genera- } \\
\text { tion (selection bias) }\end{array}$ & Low risk & $\begin{array}{l}\text { Quote: "The order of the drugs was randomized using an online randomization } \\
\text { generator" }\end{array}$ \\
\hline $\begin{array}{l}\text { Allocation concealment } \\
\text { (selection bias) }\end{array}$ & High risk & $\begin{array}{l}\text { The anaesthetist administering the drugs was aware of the drug being admin- } \\
\text { istered }\end{array}$ \\
\hline Blinding - Participant & Low risk & Study described as triple-blinded \\
\hline $\begin{array}{l}\text { Blinding - Operator/seda- } \\
\text { tionist }\end{array}$ & Low risk & $\begin{array}{l}\text { The study is described as triple-blinded therefore the operator is considered to } \\
\text { be blinded }\end{array}$ \\
\hline $\begin{array}{l}\text { Blinding - Outcome asses- } \\
\text { sor }\end{array}$ & Low risk & Study described as triple-blinded \\
\hline $\begin{array}{l}\text { Incomplete outcome as- } \\
\text { sessment }\end{array}$ & Low risk & All participants included in the outcome evaluation \\
\hline Free of selective reporting & Low risk & All planned outcomes reported \\
\hline Free of other bias & Low risk & No other bias \\
\hline
\end{tabular}


Torres-Perez 2007

$\begin{array}{ll}\text { Methods } & \text { Parallel group RCT } \\ & \text { Location: Mexico } \\ & \text { Funding: not stated }\end{array}$

\begin{tabular}{ll}
\hline Participants & $\mathrm{n}=54$ \\
& Mean age (age range) in years, gender, mean weight (range) kg: \\
& Group 1: $3.9(4-6), 11$ males and 7 females, $18.1(0.9-22)$ \\
& Group 2: $2.83(1-8), 11$ males and 7 females, $15(10.4-22.5)$ \\
& Group 3: $2.94(1-10), 10$ males and 8 females, $16.33(10.4-20)$ \\
\hline Interventions & Group $1(\mathrm{n}=18):$ hydroxyzine $(2 \mathrm{mg} / \mathrm{kg} 2$ hours before, $1 \mathrm{mg} / \mathrm{kg} 20 \mathrm{minutes}$ before $)$ \\
& Group $2(\mathrm{n}=18):$ midazolam $(0.5 \mathrm{mg} / \mathrm{kg})+$ hydroxyzine $(1.5 \mathrm{mg} / \mathrm{kg})$ \\
& Group $3(\mathrm{n}=18):$ chloral hydrate $(50 \mathrm{mg} / \mathrm{kg})+$ hydroxyzine $(1.5 \mathrm{mg} / \mathrm{kg})$ \\
& All oral
\end{tabular}

Outcomes

Ohio State Behavioral Rating Scale, cardiac rate, oxygen saturation

\section{Notes}

\section{Risk of bias}

\begin{tabular}{|c|c|c|}
\hline Bias & Authors' judgement & Support for judgement \\
\hline $\begin{array}{l}\text { Random sequence genera- } \\
\text { tion (selection bias) }\end{array}$ & Unclear risk & "Randomly assigned" - method of sequence generation not described \\
\hline $\begin{array}{l}\text { Allocation concealment } \\
\text { (selection bias) }\end{array}$ & Unclear risk & Not described \\
\hline Blinding - Participant & High risk & No blinding reported \\
\hline $\begin{array}{l}\text { Blinding - Operator/seda- } \\
\text { tionist }\end{array}$ & High risk & No blinding reported \\
\hline $\begin{array}{l}\text { Blinding - Outcome asses- } \\
\text { sor }\end{array}$ & Low risk & Observer "was not informed of the objective of the study" \\
\hline $\begin{array}{l}\text { Incomplete outcome as- } \\
\text { sessment }\end{array}$ & High risk & Numbers evaluated not stated \\
\hline Free of selective reporting & Low risk & All planned outcomes reported \\
\hline Free of other bias & Low risk & No apparent differences between groups at baseline \\
\hline
\end{tabular}

Tyagi 2012

Methods Parallel design RCT

Sedation of children undergoing dental treatment (Review) 
Tyagi 2012 (Continued)

Funding: not stated

Location: India

\begin{tabular}{|c|c|}
\hline Participants & $\begin{array}{l}\text { Inclusion criteria: Frankl rating } 1 \text { (definitely negative) at the initial visit in spite of use of behav- } \\
\text { iour modification techniques } \\
\mathrm{n}=40 \\
\text { Age range }=2 \text { to } 10 \text { years }\end{array}$ \\
\hline Interventions & $\begin{array}{l}\text { Group 1: oral midazolam }(0.5 \mathrm{mg} / \mathrm{kg}) \\
\text { Group 2: oral diazepam }(0.5 \mathrm{mg} / \mathrm{kg}) \\
\text { Group 3: IV midazolam }(0.06 \mathrm{mg} / \mathrm{kg}) \\
\text { Group 4: placebo }\end{array}$ \\
\hline Outcomes & Houpt scale, child behaviour questionnaire \\
\hline Notes & $\begin{array}{l}\text { Error in abstract, "Positive behavior of patients in group } 2 \text { and } 3 \text { did not show significant difference but } \\
\text { positive behavior in group } 3 \text { was significantly }(P<0.05) \text { more than group } 2 " \\
\text { Abstract mentions the study as triple-blinded whereas in material and methods study has been classi- } \\
\text { fied as double-blinded }\end{array}$ \\
\hline
\end{tabular}

Risk of bias

\begin{tabular}{|c|c|c|}
\hline Bias & Authors' judgement & Support for judgement \\
\hline $\begin{array}{l}\text { Random sequence genera- } \\
\text { tion (selection bias) }\end{array}$ & Unclear risk & $\begin{array}{l}\text { Study described as randomised but no details of the randomisation procedure } \\
\text { described }\end{array}$ \\
\hline $\begin{array}{l}\text { Allocation concealment } \\
\text { (selection bias) }\end{array}$ & Unclear risk & Not described \\
\hline Blinding - Participant & High risk & Blinding not done for IV midazolam group \\
\hline $\begin{array}{l}\text { Blinding - Operator/seda- } \\
\text { tionist }\end{array}$ & High risk & $\begin{array}{l}\text { Sedation procedures and randomisation were performed with the assistance } \\
\text { of a registered anaesthetist. The operator was blinded from the type of med- } \\
\text { ication used in group } 1,2 \text { and } 4 \text {. Blinding not done for IV midazolam group }\end{array}$ \\
\hline \multirow[t]{2}{*}{$\begin{array}{l}\text { Blinding - Outcome asses- } \\
\text { sor }\end{array}$} & High risk & $\begin{array}{l}\text { Quote: "Monitoring of vital signs was performed by an evaluator who was } \\
\text { blinded for the use of oral sedative agent" }\end{array}$ \\
\hline & & Comment: not blinded for IV midazolam group \\
\hline $\begin{array}{l}\text { Incomplete outcome as- } \\
\text { sessment }\end{array}$ & Low risk & All participants included in the outcome evaluation \\
\hline Free of selective reporting & Low risk & All planned outcomes reported \\
\hline Free of other bias & High risk & $\begin{array}{l}\text { Not triple-blinded as IV midazolam group was not included in the blinding, on- } \\
\text { ly oral groups were blinded. Demographics at baseline not described }\end{array}$ \\
\hline
\end{tabular}


Veerkamp 1993

\begin{tabular}{|c|c|c|}
\hline \multirow[t]{3}{*}{ Methods } & \multicolumn{2}{|l|}{ Parallel group RCT } \\
\hline & \multicolumn{2}{|c|}{ Location: the Netherlands } \\
\hline & \multicolumn{2}{|l|}{ Funding: not stated } \\
\hline Participants & \multicolumn{2}{|c|}{$\begin{array}{l}\text { Inclusion criteria: healthy Dutch speaking children aged } 6 \text { to } 11 \text { years, requiring } 2 \text { dental treatment ses- } \\
\text { sions; all children had previous treatment session aborted at separate location; scored high on Likert } \\
\text { anxiety scale }(n=56) \\
\text { Age range all subjects }=6 \text { to } 11 \text { years }\end{array}$} \\
\hline Interventions & \multicolumn{2}{|c|}{$\begin{array}{l}\text { Group } 1(n=27) \text { : behaviour management } \\
\text { Group } 2(n=29): \text { up to } 40: 60 \text { nitrous oxide/oxygen } \\
\text { Inhalation, interventions administered by dentist }\end{array}$} \\
\hline Outcomes & \multicolumn{2}{|l|}{ Venham scale } \\
\hline Notes & \multicolumn{2}{|c|}{$\begin{array}{l}\text { Dr Veerkamp was contacted to clarify the blinding in this trial and to enquire about any unpublished tri- } \\
\text { als }\end{array}$} \\
\hline \multicolumn{3}{|l|}{ Risk of bias } \\
\hline Bias & Authors' judgement & Support for judgement \\
\hline $\begin{array}{l}\text { Random sequence genera- } \\
\text { tion (selection bias) }\end{array}$ & Unclear risk & $\begin{array}{l}\text { "Divided randomly into } 2 \text { matching (age, sex) groups" - method of sequence } \\
\text { generation not described }\end{array}$ \\
\hline $\begin{array}{l}\text { Allocation concealment } \\
\text { (selection bias) }\end{array}$ & Unclear risk & Not described \\
\hline Blinding - Participant & High risk & Not blinded \\
\hline $\begin{array}{l}\text { Blinding - Operator/seda- } \\
\text { tionist }\end{array}$ & High risk & Not blinded \\
\hline $\begin{array}{l}\text { Blinding - Outcome asses- } \\
\text { sor }\end{array}$ & Low risk & $\begin{array}{l}\text { Viewed by dentist and psychologist who "were not aware of the objective of } \\
\text { the study" }\end{array}$ \\
\hline $\begin{array}{l}\text { Incomplete outcome as- } \\
\text { sessment }\end{array}$ & Low risk & All randomised participants included in outcome evaluation \\
\hline Free of selective reporting & Low risk & All planned outcomes reported \\
\hline Free of other bias & Unclear risk & Little information on participants in each group at baseline \\
\hline
\end{tabular}

Wan 2006

\begin{tabular}{ll}
\hline Methods & Parallel group RCT \\
& Location: China \\
& Funding: not stated \\
\hline Participants & Inclusion criteria: healthy unco-operative children \\
& $\mathrm{n}=40$
\end{tabular}


Wan 2006 (Continued)

Mean age (range) in years: all subjects 7.3 (5-10)

Mean weight (range) in kg: all subjects 22.9 (16-32)

\begin{tabular}{ll}
\hline Interventions & Group $1(\mathrm{n}=19):$ placebo \\
& Group $2(\mathrm{n}=21):$ midazolam $(0.5 \mathrm{mg} / \mathrm{kg})$ \\
\hline Outcomes & Ramsay, Brietkopf and Buttner, Frankl, Houpt scales \\
\hline Notes & Papoose board \\
\hline
\end{tabular}

Risk of bias

\begin{tabular}{|c|c|c|}
\hline Bias & Authors' judgement & Support for judgement \\
\hline $\begin{array}{l}\text { Random sequence genera- } \\
\text { tion (selection bias) }\end{array}$ & Unclear risk & "Randomly divided" - method of sequence generation not described \\
\hline $\begin{array}{l}\text { Allocation concealment } \\
\text { (selection bias) }\end{array}$ & Unclear risk & Not described \\
\hline Blinding - Participant & Low risk & Study described as double-blind \\
\hline $\begin{array}{l}\text { Blinding - Operator/seda- } \\
\text { tionist }\end{array}$ & Low risk & Study described as double-blind \\
\hline $\begin{array}{l}\text { Blinding - Outcome asses- } \\
\text { sor }\end{array}$ & Low risk & $\begin{array}{l}\text { Outcomes assessed from videotapes by dentist and anaesthetist unaware of } \\
\text { allocated treatment }\end{array}$ \\
\hline $\begin{array}{l}\text { Incomplete outcome as- } \\
\text { sessment }\end{array}$ & Low risk & All randomised participants included in outcome assessment \\
\hline Free of selective reporting & Low risk & All planned outcomes reported \\
\hline Free of other bias & Low risk & No apparent differences between groups at baseline \\
\hline
\end{tabular}

Özen 2012

\begin{tabular}{ll}
\hline Methods & Parallel design \\
& Funding: not stated \\
& Location: Turkey \\
\hline Participants & $\begin{array}{l}\text { Inclusion criteria: ASA } 1 \text {; children with definitely or slightly negative behaviour ratings on the Frankl Be- } \\
\text { haviour Rating Scale and who had prior experience with sedation or general anaesthesia }\end{array}$ \\
& $\begin{array}{l}\text { Age range }=4 \text { to } 6 \text { years } \\
\text { Interventions }\end{array}$ \\
\hline $\begin{array}{l}\text { Group } 1 \text { ( } \mathrm{n}=60): \text { midazolam }(0.20 \mathrm{mg} / \mathrm{kg})(40 \mathrm{mg} / \mathrm{ml}) \text { intranasally, inhalation sedation } 50 \% / 50 \% \text { ni- } \\
\text { trous oxide/oxygen }\end{array}$
\end{tabular}


Özen 2012 (Continued)

Group $2(\mathrm{n}=60)$ : midazolam $(0.75 \mathrm{mg} / \mathrm{kg})(15 \mathrm{mg} / 3 \mathrm{ml})$ orally, inhalation sedation $50 \% / 50 \%$ nitrous oxide/oxygen

Group 3 ( $\mathrm{n}=60)$ : midazolam $(0.50 \mathrm{mg} / \mathrm{kg})(15 \mathrm{mg} / 3 \mathrm{ml})$ orally, inhalation sedation $50 \% / 50 \%$ nitrous oxide/oxygen

Group $4(n=60)$ : inhalation sedation $50 \% / 50 \%$ nitrous oxide/oxygen

\begin{tabular}{ll}
\hline Outcomes & Bispectral Index System; modified scale to classify behaviour; Vancouver Recovery Scale \\
\hline Notes & Restraint used
\end{tabular}

\section{Risk of bias}

\begin{tabular}{|c|c|c|}
\hline Bias & Authors' judgement & Support for judgement \\
\hline $\begin{array}{l}\text { Random sequence genera- } \\
\text { tion (selection bias) }\end{array}$ & Unclear risk & Not described \\
\hline $\begin{array}{l}\text { Allocation concealment } \\
\text { (selection bias) }\end{array}$ & Unclear risk & Not described \\
\hline Blinding - Participant & Unclear risk & Not described \\
\hline $\begin{array}{l}\text { Blinding - Operator/seda- } \\
\text { tionist }\end{array}$ & Unclear risk & Not described \\
\hline $\begin{array}{l}\text { Blinding - Outcome asses- } \\
\text { sor }\end{array}$ & Unclear risk & Not described \\
\hline $\begin{array}{l}\text { Incomplete outcome as- } \\
\text { sessment }\end{array}$ & High risk & $\begin{array}{l}\text { Difficult to gather if dropouts had occurred. Percentage of patients that did not } \\
\text { accept route of treatment mentioned }\end{array}$ \\
\hline Free of selective reporting & Low risk & All planned outcomes reported \\
\hline Free of other bias & High risk & Little information on participants in each group as baseline \\
\hline
\end{tabular}

ASA I/ASA II = American Society of Anesthesiologists (ASA) physical status classification; BIS = bispectral index; DSTG = Dental SedationTeachers Group scale; ITT = intention-to-treat; IV = intravenous; LA = local anaesthesia; $\mathrm{min}=$ minute; $\mathrm{RCT}=$ randomised controlled trial; SD = standard deviation; $\mathrm{SE}=$ standard error.

Characteristics of excluded studies [ordered by study ID]

\begin{tabular}{ll}
\hline Study & Reason for exclusion \\
\hline Al-Zahrani 2009 & Cross-over trial \\
\hline Arya 2002 & Participants not randomly assigned \\
\hline Badalaty 1990 & Cross-over trial \\
\hline Baldinelli 1989 & No comparison of groups \\
\hline Berge 1999 & No comparison of groups \\
\hline Blake 1999 & Ages ranging from 3 to 46 years \\
\hline
\end{tabular}




\begin{tabular}{|c|c|}
\hline Study & Reason for exclusion \\
\hline & Review authors assumed the subjects were adults \\
\hline Campbell 1998 & Participants not randomly assigned (explicitly stated) \\
\hline Canpolat 2017 & Described as deep sedation \\
\hline Cathers 2005 & Cross-over trial \\
\hline Chaushu 2002 & No comparison of groups \\
\hline Coldwell 1999 & Evaluates adverse effects only \\
\hline da Costa 2007 & Cross-over trial \\
\hline Dallman 2001 & Cross- over trial \\
\hline Davila 1990 & Review \\
\hline Doring 1985 & Not comparative \\
\hline Downs 1997 & Cross-over trial \\
\hline Duncan 1984 & Survey \\
\hline Duncan 1994 & No comparison of groups \\
\hline Dunn-Russell 1993 & No comparison of groups \\
\hline el Magboul 1995 & Cross-over trial \\
\hline Erlandsson 2001 & No comparison of groups \\
\hline Evans 1966 & Cross-over trial \\
\hline Flaitz 1985 & Cross-over trial \\
\hline Fuks 1994 & Cross-over trial \\
\hline Fukuta 1993 & $\begin{array}{l}\text { No comparison of groups } \\
\text { Ages } 4 \text { to } 21 \text { years }\end{array}$ \\
\hline Fukuta 1994 & Ages from 5 to 20 years \\
\hline Gallardo 1984 & Cross-over trial \\
\hline Gamonal Aravena 1989 & Cross-over trial \\
\hline Garton 1970 & Review \\
\hline Haas 1996 & Cross-over trial \\
\hline Hall 2006 & Adults \\
\hline Hartgraves 1994 & Cross-over trial \\
\hline
\end{tabular}




\begin{tabular}{|c|c|}
\hline Study & Reason for exclusion \\
\hline Hasty 1991 & Cross-over trial \\
\hline Heard 2010 & Not randomised \\
\hline Henry 1990 & Compares scavenged/non-scavenged groups with regard to levels of ambient nitrous oxide \\
\hline Houpt 1985a & Cross-over trial \\
\hline Houpt $1985 b$ & Cross-over trial \\
\hline Houpt 1989 & Cross-over trial \\
\hline Houpt 1996 & Cross-over trial \\
\hline Hulland 2002 & Retrospective \\
\hline Isik 2008 & Looked at the effect of flavouring on acceptability of oral sedatives \\
\hline Jensen 1998 & Retrospective study \\
\hline Kantovitz 2007 & Cross-over trial \\
\hline Kayalibay 1987 & Review \\
\hline Kerins 2007 & Not randomised \\
\hline Kopel 1971 & Not randomised \\
\hline Koroluk 2000 & Retrospective study \\
\hline Kramer 1991a & No comparison of groups \\
\hline Kramer 1991b & No comparison of groups \\
\hline Kupietzky 1996 & No relevant outcomes \\
\hline Lahoud 2001 & Pilot study - no comparative group \\
\hline Leelataweedwud 2001 & Retrospective study \\
\hline Leelataweewud 2000 & Cross-over trial \\
\hline Lima 2003 & Cross-over trial \\
\hline Lindh-Stromberg 2001 & No comparison of groups \\
\hline Lindsay 1980 & Cross-over trial \\
\hline Lindsay 1985 & Cross-over trial \\
\hline Litman 1997 & Premedication before general anaesthesia \\
\hline Litman 1998 & Not randomised (author contacted) \\
\hline Lökken 1994 & Cross-over trial \\
\hline
\end{tabular}




\begin{tabular}{|c|c|}
\hline Study & Reason for exclusion \\
\hline Machen 1977 & No relevant outcomes \\
\hline Malamed 1989 & No comparison of groups \\
\hline Marshall 1999 & $\begin{array}{l}\text { The study was based on } 56 \text { different treatment attempts on } 34 \text { patients. Therefore it was a } \\
\text { partial cross-over design as some of the patients would have had more than } 1 \text { type of treat- } \\
\text { ment }\end{array}$ \\
\hline Martinez 2006 & Not randomised \\
\hline McCann 1996 & Cross-over trial \\
\hline Milnes 2000 & No comparison of groups \\
\hline Moore 1997 & No comparison of groups \\
\hline Musial 2003 & Cross-over trial \\
\hline Myers 1977 & No comparison of groups \\
\hline Myers 2004 & Cross-over trial \\
\hline Nathan 1987 & Not randomised \\
\hline Oei-Lim 1991 & $\begin{array}{l}\text { No comparison of groups } \\
\text { Ages ranging from } 23 \text { to } 37 \text { years, mental and physical handicapped }\end{array}$ \\
\hline Pandey 2010 & Cross-over trial \\
\hline Pisalchaiyong 2005 & Cross-over trial \\
\hline Poorman 1990 & Not randomised \\
\hline Primosch 1999 & Cross-over trial \\
\hline Primosch 2001 & $\begin{array}{l}\text { Retrospective study } \\
\text { No comparison of groups }\end{array}$ \\
\hline Quarnstrom 1992 & Not randomised \\
\hline Ram 1999 & Cross-over trial \\
\hline Reinemer 1996 & $\begin{array}{l}\text { Inappropriate design, partial cross-over with some subjects having both and others only } 1 \\
\text { regimen }\end{array}$ \\
\hline Robbins 1967 & $\begin{array}{l}\text { Inappropriate design, partial cross-over with some subjects having both and others only } 1 \\
\text { regimen }\end{array}$ \\
\hline
\end{tabular}

\begin{tabular}{ll}
\hline Roberts 1979 & $\begin{array}{l}\text { Age range } 4 \text { to } 17 \text { years } \\
\text { No comparison of groups }\end{array}$ \\
\hline Roberts 1982 & No comparison of groups \\
\hline Roberts 1992 & $\begin{array}{l}\text { Inappropriate design, partial cross-over with some subjects having both and others only } 1 \\
\text { regimen }\end{array}$ \\
\hline
\end{tabular}




\begin{tabular}{|c|c|}
\hline Study & Reason for exclusion \\
\hline Robertson 1998 & $\begin{array}{l}\text { Not randomised (quasi-randomisation). First patient randomised by toss of a coin, remain- } \\
\text { ing patients alternated }\end{array}$ \\
\hline Roelofse 1990 & Premedication before general anaesthesia \\
\hline Roelofse 1993 & Premedication before general anaesthesia \\
\hline Rohlfing 1998 & No comparison of groups \\
\hline Sams 1992 & No relevant outcome \\
\hline Sams 1993b & Review \\
\hline Sanders 1997 & No comparison of groups \\
\hline Shapira 1992 & Cross-over trial \\
\hline Shapira 1996 & Cross-over trial \\
\hline Shapira 2004 & Cross-over trial \\
\hline Sharma 1992 & Inappropriate design (partial cross-over) \\
\hline Sheroan 2006 & Cross-over trial \\
\hline Silver 1994 & Ages from 3 to 18 years \\
\hline Songvasin 1990 & Cross-over trial \\
\hline Subramaniam 2017 & $\begin{array}{l}\text { Interventions not randomised: "Based on the parent preference of the route of administra- } \\
\text { tion, children were then randomly divided into } 2 \text { groups" }\end{array}$ \\
\hline Sullivan 2001 & Cross-over trial \\
\hline Tanaka 2000 & General anaesthesia \\
\hline Tobias 1975 & Not randomised \\
\hline Tsinidou 1992 & Cross-over trial \\
\hline van der Bijl 1991 & Adults \\
\hline Varpio 1991 & Not randomised \\
\hline Veerkamp 1997 & Deep sedation \\
\hline Whitehead 1988 & Not randomised (author contacted to confirm) \\
\hline Wilson 1990 & Retrospective study \\
\hline Wilson 1992 & Dose response study measuring physiological outcomes \\
\hline Wilson 1993 & Cross-over trial \\
\hline Wilson 2000 & Retrospective study \\
\hline
\end{tabular}




\begin{tabular}{ll}
\hline Study & Reason for exclusion \\
\hline Wilson 2002 & Cross-over trial \\
\hline Wilson 2003 & Cross-over trial \\
\hline Wilson 2006 & Cross-over trial \\
\hline Wilson 2007 & Cross-over trial \\
\hline Yanase 1996 & Cross-over trial \\
\hline
\end{tabular}

\section{DATA AND ANALYSES}

\section{Comparison 1. Sedatives versus placebo}

\begin{tabular}{|c|c|c|c|c|}
\hline $\begin{array}{l}\text { Outcome or subgroup ti- } \\
\text { tle }\end{array}$ & No. of studies & $\begin{array}{l}\text { No. of partici- } \\
\text { pants }\end{array}$ & Statistical method & Effect size \\
\hline $\begin{array}{l}1 \text { Mean Houpt/other be- } \\
\text { havioural score }\end{array}$ & 7 & & Std. Mean Difference (IV, Fixed, 95\% CI) & Subtotals only \\
\hline 1.1 Midazolam (oral) & 6 & 202 & Std. Mean Difference (IV, Fixed, 95\% Cl) & $1.96[1.59,2.33]$ \\
\hline $\begin{array}{l}1.2 \text { Midazolam (intra- } \\
\text { venous) }\end{array}$ & 1 & 20 & Std. Mean Difference (IV, Fixed, 95\% CI) & $1.21[0.24,2.18]$ \\
\hline $\begin{array}{l}1.3 \text { Nitrous oxide versus } \\
\text { placebo }\end{array}$ & 1 & 52 & Std. Mean Difference (IV, Fixed, 95\% Cl) & $0.69[0.13,1.26]$ \\
\hline 1.4 Diazepam (oral) & 1 & 20 & Std. Mean Difference (IV, Fixed, 95\% CI) & $0.62[-0.28,1.53]$ \\
\hline $\begin{array}{l}2 \text { Good or better behav- } \\
\text { iour }\end{array}$ & 2 & & Risk Ratio (M-H, Fixed, 95\% Cl) & Totals not selected \\
\hline 2.1 Chloral hydrate & 1 & & Risk Ratio (M-H, Fixed, 95\% Cl) & $0.0[0.0,0.0]$ \\
\hline 2.2 Meperidine & 1 & & Risk Ratio (M-H, Fixed, 95\% Cl) & $0.0[0.0,0.0]$ \\
\hline
\end{tabular}

Analysis 1.1. Comparison 1 Sedatives versus placebo, Outcome 1 Mean Houpt/other behavioural score.

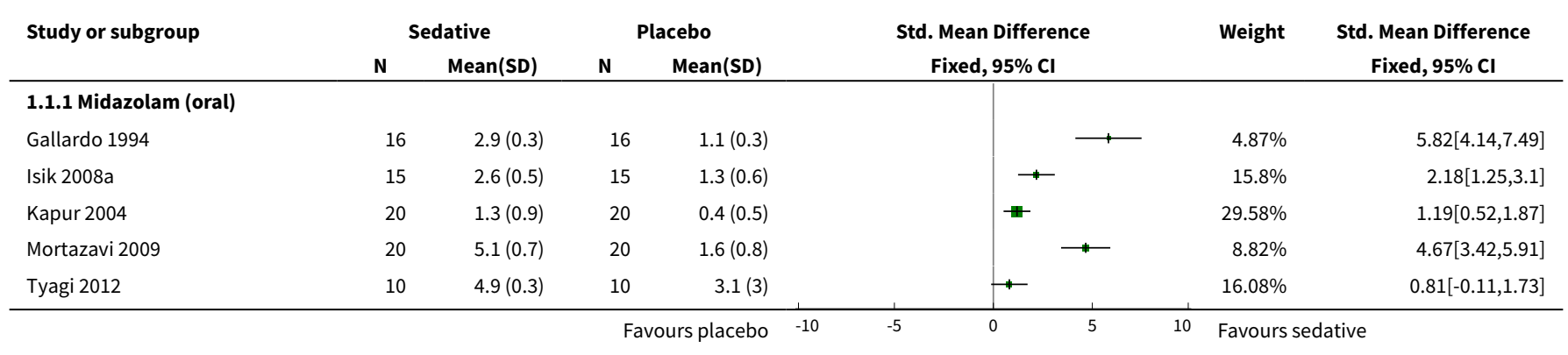




\begin{tabular}{|c|c|c|c|c|c|c|c|c|}
\hline \multirow{3}{*}{$\begin{array}{l}\text { Study or subgroup } \\
\text { Wan } 2006\end{array}$} & \multicolumn{2}{|c|}{ Sedative } & \multicolumn{2}{|c|}{ Placebo } & & \multirow{2}{*}{$\begin{array}{l}\text { Std. Mean Difference } \\
\text { Fixed, } 95 \% \mathrm{Cl}\end{array}$} & \multirow{3}{*}{$\begin{array}{l}\text { Weight } \\
24.85 \%\end{array}$} & \multirow{3}{*}{$\begin{array}{c}\text { Std. Mean Difference } \\
\text { Fixed, 95\% Cl } \\
1.75[1.01,2.49]\end{array}$} \\
\hline & \multirow{2}{*}{$\frac{\mathbf{N}}{21}$} & \multirow{2}{*}{$\frac{\operatorname{Mean}(\mathrm{SD})}{4.7(1.2)}$} & & \multirow{2}{*}{\multicolumn{2}{|c|}{$\begin{array}{r}\text { Mean(SD) } \\
2.3(1.5)\end{array}$}} & & & \\
\hline & & & & & & $\rightarrow$ & & \\
\hline 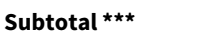 & 102 & & 100 & & & $\boldsymbol{\diamond}$ & $100 \%$ & $1.96[1.59,2.33]$ \\
\hline \multicolumn{9}{|c|}{ Heterogeneity: $\mathrm{Tau}^{2}=0 ; \mathrm{Chi}^{2}=50.09, \mathrm{df}=5(\mathrm{P}<0.0001) ; \mathrm{I}^{2}=90.02 \%$} \\
\hline \multicolumn{9}{|c|}{ Test for overall effect: $Z=10.39(P<0.0001)$} \\
\hline \multicolumn{9}{|c|}{ 1.1.2 Midazolam (intravenous) } \\
\hline Tyagi 2012 & 10 & $5.8(0.4)$ & 10 & $3.1(3)$ & & & $100 \%$ & $1.21[0.24,2.18]$ \\
\hline 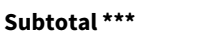 & 10 & & 10 & & & & $100 \%$ & $1.21[0.24,2.18]$ \\
\hline \multicolumn{9}{|c|}{ Heterogeneity: Not applicable } \\
\hline \multicolumn{9}{|c|}{ Test for overall effect: $\mathrm{Z}=2.44(\mathrm{P}=0.01)$} \\
\hline \multicolumn{9}{|c|}{ 1.1.3 Nitrous oxide versus placebo } \\
\hline Veerkamp 1993 & 27 & $3.5(0.9)$ & 25 & $2.8(0.8)$ & & & $100 \%$ & $0.69[0.13,1.26]$ \\
\hline Subtotal $\star \star \star$ & 27 & & 25 & & & & $100 \%$ & $0.69[0.13,1.26]$ \\
\hline \multicolumn{9}{|c|}{ Heterogeneity: Not applicable } \\
\hline \multicolumn{9}{|c|}{ Test for overall effect: $Z=2.43(P=0.02)$} \\
\hline \multicolumn{9}{|l|}{ 1.1.4 Diazepam (oral) } \\
\hline Tyagi 2012 & 10 & $4.5(0.5)$ & 10 & $3.1(3)$ & & & $100 \%$ & $0.62[-0.28,1.53]$ \\
\hline Subtotal $* \star \star$ & 10 & & 10 & & & & $100 \%$ & $0.62[-0.28,1.53]$ \\
\hline \multicolumn{9}{|c|}{ Heterogeneity: Not applicable } \\
\hline \multicolumn{9}{|c|}{ Test for overall effect: $\mathrm{Z}=1.35(\mathrm{P}=0.18)$} \\
\hline \multicolumn{9}{|c|}{ Test for subgroup differences: $\mathrm{Chi}^{2}=17.64, \mathrm{df}=1(\mathrm{P}=0), \mathrm{I}^{2}=82.99 \%$} \\
\hline
\end{tabular}

Analysis 1.2. Comparison 1 Sedatives versus placebo, Outcome 2 Good or better behaviour.

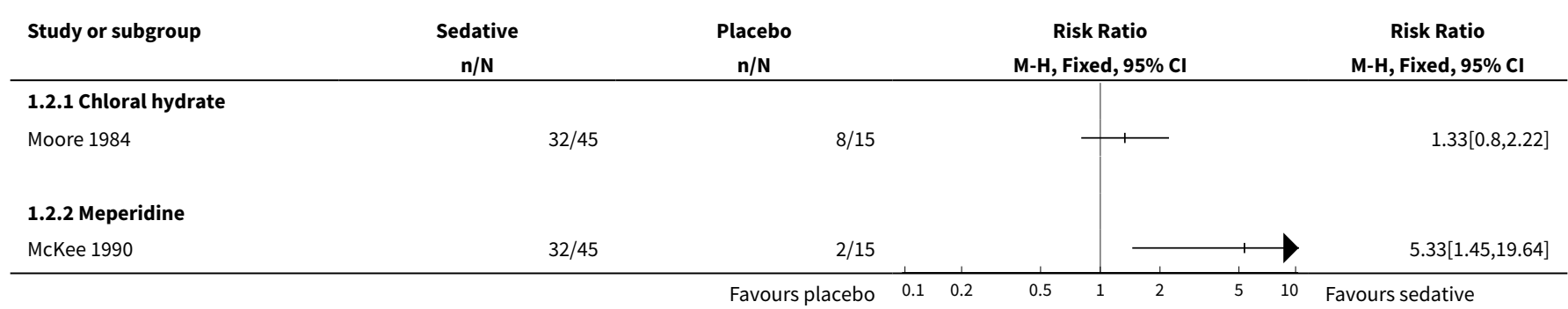

\section{Comparison 2. Chloral hydrate (CH)}

\begin{tabular}{lllll}
\hline Outcome or subgroup title & No. of studies & $\begin{array}{l}\text { No. of partici- } \\
\text { pants }\end{array}$ & Statistical method & Effect size \\
\hline $\begin{array}{l}\text { 1 Overall behaviour (ordinal scale, } \\
\text { Houpt or similar) }\end{array}$ & 5 & & $\begin{array}{l}\text { Mean Difference (IV, Fixed, 95\% } \\
\mathrm{Cl})\end{array}$ & $\begin{array}{l}\text { Totals not select- } \\
\text { ed }\end{array}$ \\
\hline $\begin{array}{llll}1.1 \mathrm{CH} \text { vs CH/hydroxyzine } \\
\text { M }\end{array}$ & 1 & $\begin{array}{l}\text { Mean Difference (IV, Fixed, 95\% } \\
\mathrm{Cl})\end{array}$ & $0.0[0.0,0.0]$ \\
\hline
\end{tabular}




\begin{tabular}{|c|c|c|c|c|}
\hline Outcome or subgroup title & No. of studies & $\begin{array}{l}\text { No. of partici- } \\
\text { pants }\end{array}$ & Statistical method & Effect size \\
\hline $1.2 \mathrm{CH} /$ hydroxyzine vs triazolam & 1 & & $\begin{array}{l}\text { Mean Difference (IV, Fixed, 95\% } \\
\mathrm{CI})\end{array}$ & $0.0[0.0,0.0]$ \\
\hline $\begin{array}{l}1.3 \mathrm{CH} / \text { hydroxyzine vs midazo- } \\
\text { lam/acetaminophen }\end{array}$ & 1 & & $\begin{array}{l}\text { Mean Difference (IV, Fixed, 95\% } \\
\mathrm{CI})\end{array}$ & $0.0[0.0,0.0]$ \\
\hline $\begin{array}{l}1.4 \mathrm{CH} / \text { promethazine vs meperi- } \\
\text { dine/promethazine }\end{array}$ & 1 & & $\begin{array}{l}\text { Mean Difference (IV, Fixed, 95\% } \\
\mathrm{CI})\end{array}$ & $0.0[0.0,0.0]$ \\
\hline $\begin{array}{l}1.5 \mathrm{CH} / \text { hydroxyzine vs } \mathrm{CH} / \text { hydrox- } \\
\text { yzine/midazolam }\end{array}$ & 1 & & $\begin{array}{l}\text { Mean Difference (IV, Fixed, 95\% } \\
\mathrm{CI})\end{array}$ & $0.0[0.0,0.0]$ \\
\hline 2 Good or better behaviour & 1 & & Risk Ratio (M-H, Fixed, 95\% Cl) & Subtotals only \\
\hline $2.1 \mathrm{CH}$ vs $\mathrm{CH}$ /hydroxyzine & 1 & 20 & Risk Ratio (M-H, Fixed, 95\% Cl) & $0.57[0.24,1.35]$ \\
\hline
\end{tabular}

\begin{tabular}{|c|c|c|c|c|c|c|}
\hline \multirow[t]{2}{*}{ Study or subgroup } & \multicolumn{2}{|c|}{ Group 1} & \multicolumn{2}{|c|}{ Group 2} & \multirow{2}{*}{$\begin{array}{c}\text { Mean Difference } \\
\text { Fixed, } 95 \% \mathrm{Cl}\end{array}$} & \multirow{2}{*}{$\begin{array}{c}\text { Mean Difference } \\
\text { Fixed, } 95 \% \mathrm{Cl}\end{array}$} \\
\hline & $\mathbf{N}$ & Mean(SD) & $\mathbf{N}$ & Mean(SD) & & \\
\hline \multicolumn{7}{|c|}{ 2.1.1 $\mathrm{CH}$ vs $\mathrm{CH} /$ hydroxyzine } \\
\hline Avalos-Arenas 1998 & 20 & $4.9(1.1)$ & 20 & $5(0.7)$ & & $-0.1[-0.67,0.47]$ \\
\hline \multicolumn{7}{|c|}{ 2.1.2 CH/hydroxyzine vs triazolam } \\
\hline Meyer 1990 & 20 & $4.3(1.9)$ & 20 & $4.3(1.9)$ & & $0[-1.18,1.18]$ \\
\hline \multicolumn{7}{|c|}{ 2.1.3 CH/hydroxyzine vs midazolam/acetaminophen } \\
\hline Reeves 1996 & 20 & $3.6(1.2)$ & 20 & $3.7(1.2)$ & & $-0.1[-0.83,0.63]$ \\
\hline \multicolumn{7}{|c|}{ 2.1.4 CH/promethazine vs meperidine/promethazine } \\
\hline Sams 1993a & 13 & $4.5(0.9)$ & 11 & $4.1(1.3)$ & 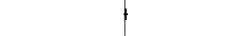 & $0.4[-0.51,1.31]$ \\
\hline \multicolumn{7}{|c|}{ 2.1.5 CH/hydroxyzine vs $\mathrm{CH} /$ hydroxyzine/midazolam } \\
\hline Park 2006 & 15 & $0.5(0.5)$ & 16 & $0.8(0.4)$ & & $-0.34[-0.66,-0.02]$ \\
\hline
\end{tabular}

Analysis 2.2. Comparison 2 Chloral hydrate (CH), Outcome 2 Good or better behaviour.

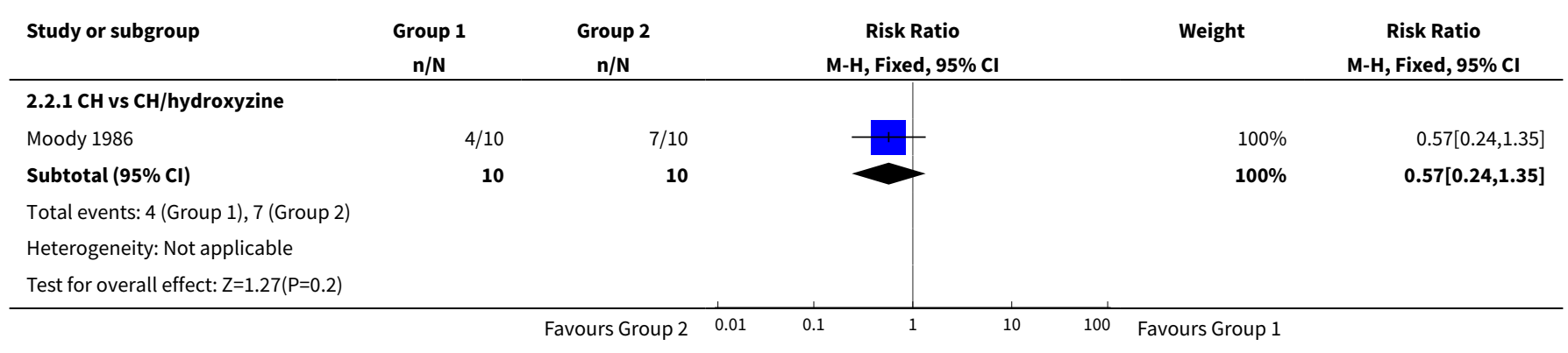


Comparison 3. Ketamine

\begin{tabular}{|c|c|c|c|c|}
\hline Outcome or subgroup title & No. of studies & $\begin{array}{l}\text { No. of partici- } \\
\text { pants }\end{array}$ & Statistical method & Effect size \\
\hline $\begin{array}{l}1 \text { Overall behaviour (ordinal scale, } \\
\text { Houpt or similar) }\end{array}$ & 5 & & $\begin{array}{l}\text { Std. Mean Difference (IV, Random, } \\
95 \% \mathrm{CI} \text { ) }\end{array}$ & $\begin{array}{l}\text { Totals not select- } \\
\text { ed }\end{array}$ \\
\hline 1.1 Ketamine vs midazolam & 2 & & $\begin{array}{l}\text { Std. Mean Difference (IV, Random, } \\
95 \% \mathrm{CI} \text { ) }\end{array}$ & $0.0[0.0,0.0]$ \\
\hline 1.2 Ketamine vs propofol & 1 & & $\begin{array}{l}\text { Std. Mean Difference (IV, Random, } \\
95 \% \mathrm{CI} \text { ) }\end{array}$ & $0.0[0.0,0.0]$ \\
\hline $\begin{array}{l}1.3 \text { Ketamine/midazolam vs } \\
\text { trimeprazine/methadone }\end{array}$ & 1 & & $\begin{array}{l}\text { Std. Mean Difference (IV, Random, } \\
95 \% \mathrm{CI} \text { ) }\end{array}$ & $0.0[0.0,0.0]$ \\
\hline $\begin{array}{l}\text { 1.4 Ketamine vs meperi- } \\
\text { dine/promethazine }\end{array}$ & 1 & & $\begin{array}{l}\text { Std. Mean Difference (IV, Random, } \\
95 \% \mathrm{CI} \text { ) }\end{array}$ & $0.0[0.0,0.0]$ \\
\hline $\begin{array}{l}1.5 \text { Ketamine vs ketamine/promet- } \\
\text { hazine }\end{array}$ & 1 & & $\begin{array}{l}\text { Std. Mean Difference (IV, Random, } \\
95 \% \mathrm{CI} \text { ) }\end{array}$ & $0.0[0.0,0.0]$ \\
\hline 2 Good or better behaviour & 2 & & Risk Ratio (M-H, Fixed, 95\% Cl) & $\begin{array}{l}\text { Totals not select- } \\
\text { ed }\end{array}$ \\
\hline $\begin{array}{l}2.1 \text { Ketamine vs trimeprazine/ } \\
\text { methadone/droperidol }\end{array}$ & 1 & & Risk Ratio (M-H, Fixed, 95\% Cl) & $0.0[0.0,0.0]$ \\
\hline $\begin{array}{l}2.2 \text { Ketamine/midazolam vs } \\
\text { trimeprazine/methadone }\end{array}$ & 1 & & Risk Ratio (M-H, Fixed, 95\% Cl) & $0.0[0.0,0.0]$ \\
\hline
\end{tabular}

Analysis 3.1. Comparison 3 Ketamine, Outcome 1 Overall behaviour (ordinal scale, Houpt or similar).

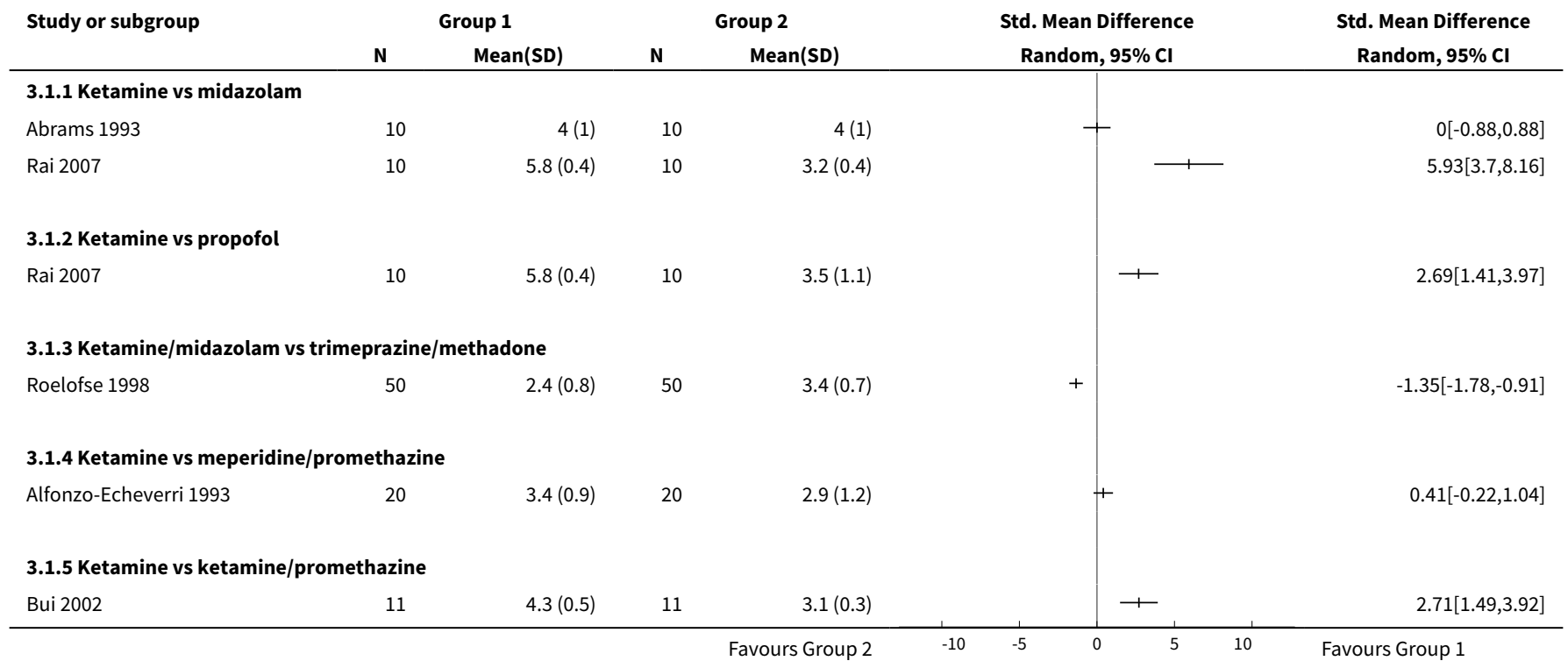


Analysis 3.2. Comparison 3 Ketamine, Outcome 2 Good or better behaviour.

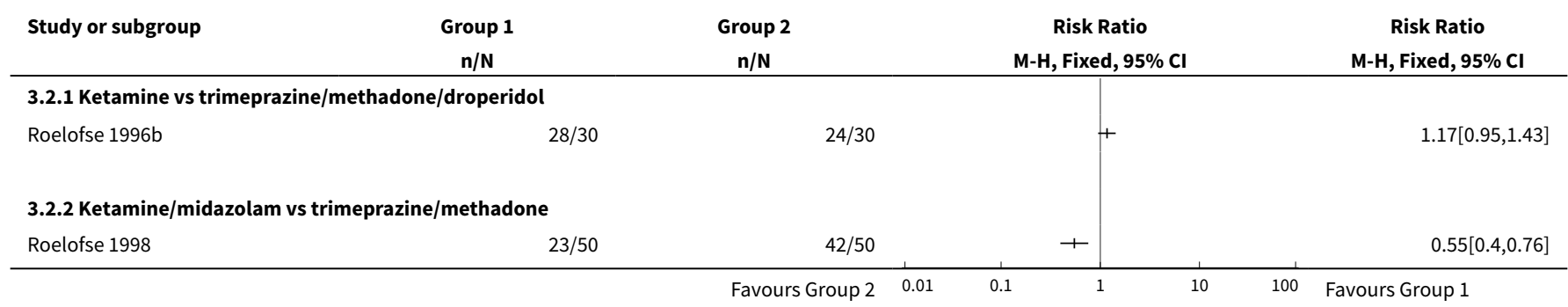

Comparison 4. Midazolam (versus other)

\begin{tabular}{|c|c|c|c|c|}
\hline Outcome or subgroup title & No. of studies & $\begin{array}{l}\text { No. of partici- } \\
\text { pants }\end{array}$ & Statistical method & Effect size \\
\hline $\begin{array}{l}1 \text { Overall behaviour (ordinal } \\
\text { scale, Houpt or similar) }\end{array}$ & 12 & & $\begin{array}{l}\text { Std. Mean Difference (IV, Random, } \\
95 \% \mathrm{CI})\end{array}$ & $\begin{array}{l}\text { Totals not select- } \\
\text { ed }\end{array}$ \\
\hline $\begin{array}{l}\text { 1.1 Midazolam (low dose) vs mi- } \\
\text { dazolam (high dose) }\end{array}$ & 2 & & $\begin{array}{l}\text { Std. Mean Difference (IV, Random, } \\
95 \% \mathrm{CI})\end{array}$ & $0.0[0.0,0.0]$ \\
\hline $\begin{array}{l}1.2 \text { Midazolam (intramuscular) } \\
\text { vs midazolam (intranasal) }\end{array}$ & 2 & & $\begin{array}{l}\text { Std. Mean Difference (IV, Random, } \\
95 \% \mathrm{CI})\end{array}$ & $0.0[0.0,0.0]$ \\
\hline 1.3 Midazolam vs ketamine & 2 & & $\begin{array}{l}\text { Std. Mean Difference (IV, Random, } \\
95 \% \mathrm{CI})\end{array}$ & $0.0[0.0,0.0]$ \\
\hline 1.4 Midazolam vs nitrous oxide & 1 & & $\begin{array}{l}\text { Std. Mean Difference (IV, Random, } \\
95 \% \mathrm{CI})\end{array}$ & $0.0[0.0,0.0]$ \\
\hline 1.5 Midazolam vs hydroxyzine & 1 & & $\begin{array}{l}\text { Std. Mean Difference (IV, Random, } \\
95 \% \mathrm{CI} \text { ) }\end{array}$ & $0.0[0.0,0.0]$ \\
\hline $\begin{array}{l}\text { 1.6 Midazolam vs midazo- } \\
\text { lam/ketamine }\end{array}$ & 2 & & $\begin{array}{l}\text { Std. Mean Difference (IV, Random, } \\
95 \% \mathrm{CI})\end{array}$ & $0.0[0.0,0.0]$ \\
\hline 1.7 Midazolam vs promethazine & 1 & & $\begin{array}{l}\text { Std. Mean Difference (IV, Random, } \\
95 \% \mathrm{CI})\end{array}$ & $0.0[0.0,0.0]$ \\
\hline 1.8 Midazolam vs triclofos & 1 & & $\begin{array}{l}\text { Std. Mean Difference (IV, Random, } \\
95 \% \mathrm{CI} \text { ) }\end{array}$ & $0.0[0.0,0.0]$ \\
\hline 1.9 Midazolam vs propofol & 1 & & $\begin{array}{l}\text { Std. Mean Difference (IV, Random, } \\
95 \% \mathrm{CI})\end{array}$ & $0.0[0.0,0.0]$ \\
\hline $\begin{array}{l}\text { 1.10 Midazolam/aceta- } \\
\text { minophen vs } \mathrm{CH} / \text { hydroxyzine }\end{array}$ & 1 & & $\begin{array}{l}\text { Std. Mean Difference (IV, Random, } \\
95 \% \mathrm{CI})\end{array}$ & $0.0[0.0,0.0]$ \\
\hline $\begin{array}{l}\text { 1.11 Midazolam/ketamine vs } \\
\text { trimeprazine/methadone }\end{array}$ & 1 & & $\begin{array}{l}\text { Std. Mean Difference (IV, Random, } \\
95 \% \mathrm{CI})\end{array}$ & $0.0[0.0,0.0]$ \\
\hline
\end{tabular}




\begin{tabular}{|c|c|c|c|c|}
\hline Outcome or subgroup title & No. of studies & $\begin{array}{l}\text { No. of partici- } \\
\text { pants }\end{array}$ & Statistical method & Effect size \\
\hline $\begin{array}{l}1.12 \text { Midazolam (oral) vs mida- } \\
\text { zolam (intravenous) }\end{array}$ & 1 & & $\begin{array}{l}\text { Std. Mean Difference (IV, Random, } \\
95 \% \mathrm{CI})\end{array}$ & $0.0[0.0,0.0]$ \\
\hline 1.13 Midazolam vs diazepam & 1 & & $\begin{array}{l}\text { Std. Mean Difference (IV, Random, } \\
95 \% \mathrm{CI})\end{array}$ & $0.0[0.0,0.0]$ \\
\hline 2 Good or better sedation & 1 & & Risk Ratio (M-H, Fixed, $95 \% \mathrm{Cl}$ ) & $\begin{array}{l}\text { Totals not select- } \\
\text { ed }\end{array}$ \\
\hline $\begin{array}{l}2.1 \text { Midazolam (rectal) vs di- } \\
\text { azepam (rectal) }\end{array}$ & 1 & & Risk Ratio (M-H, Fixed, $95 \% \mathrm{Cl}$ ) & $0.0[0.0,0.0]$ \\
\hline
\end{tabular}

\section{Analysis 4.1. Comparison 4 Midazolam (versus other), Outcome 1 Overall behaviour (ordinal scale, Houpt or similar).}

\begin{tabular}{|c|c|c|c|c|c|c|c|}
\hline \multirow[t]{2}{*}{ Study or subgroup } & \multicolumn{2}{|c|}{ Group 1} & \multicolumn{2}{|c|}{ Group 2} & \multirow{2}{*}{\multicolumn{2}{|c|}{$\begin{array}{c}\text { Std. Mean Difference } \\
\text { Random, } 95 \% \mathrm{CI}\end{array}$}} & \multirow{2}{*}{$\begin{array}{c}\text { Std. Mean Difference } \\
\text { Random, } 95 \% \mathrm{CI}\end{array}$} \\
\hline & $\mathbf{N}$ & Mean(SD) & $\mathbf{N}$ & Mean(SD) & & & \\
\hline \multicolumn{5}{|c|}{ 4.1.1 Midazolam (low dose) vs midazolam (high dose) } & & & \\
\hline Al-Rakaf 2001 & 12 & $3.4(1.3)$ & 13 & $4.9(0.6)$ & $千$ & & $-1.43[-2.32,-0.53]$ \\
\hline Isik 2008b & 14 & $1.2(0.4)$ & 13 & $2.7(0.6)$ & 1 & & $-2.87[-4,-1.75]$ \\
\hline \multicolumn{8}{|c|}{ 4.1.2 Midazolam (intramuscular) vs midazolam (intranasal) } \\
\hline Shashikiran 2006 & 20 & $2.2(0.5)$ & 20 & $2.2(0.6)$ & & + & $0.09[-0.53,0.71]$ \\
\hline \multicolumn{8}{|c|}{ 4.1.3 Midazolam vs ketamine } \\
\hline Abrams 1993 & 10 & $4(1)$ & 10 & $4(1)$ & - & + & $0[-0.88,0.88]$ \\
\hline Rai 2007 & 10 & $3.2(0.4)$ & 10 & $5.8(0.4)$ & & & $-5.93[-8.16,-3.7]$ \\
\hline Baygin 2010 & 15 & $2.3(0.8)$ & 15 & $1.7(0.6)$ & & + & $0.78[0.03,1.52]$ \\
\hline \multicolumn{8}{|c|}{ 4.1.5 Midazolam vs hydroxyzine } \\
\hline Baygin 2010 & 15 & $2.3(0.8)$ & 15 & $1.8(0.7)$ & & + & $0.65[-0.09,1.38]$ \\
\hline \multicolumn{8}{|c|}{ 4.1.6 Midazolam vs midazolam/ketamine } \\
\hline Baygin 2010 & 15 & $2.3(0.8)$ & 15 & $2(0.9)$ & & + & $0.35[-0.37,1.07]$ \\
\hline Roelofse 1996a & 50 & $3.2(0.6)$ & 50 & $3.6(0.6)$ & + & & $-0.56[-0.96,-0.16]$ \\
\hline \multicolumn{8}{|c|}{ 4.1.7 Midazolam vs promethazine } \\
\hline Singh 2002 & 30 & $3.3(0.7)$ & 30 & $2.7(0.5)$ & & + & $0.92[0.39,1.46]$ \\
\hline \multicolumn{8}{|c|}{ 4.1.8 Midazolam vs triclofos } \\
\hline \multicolumn{8}{|c|}{ 4.1.9 Midazolam vs propofol } \\
\hline Rai 2007 & 10 & $3.2(0.4)$ & 10 & $3.5(1.1)$ & 1 & - & $-0.35[-1.24,0.53]$ \\
\hline \multicolumn{8}{|c|}{ 4.1.10 Midazolam/acetaminophen vs $\mathrm{CH} /$ hydroxyzine } \\
\hline
\end{tabular}




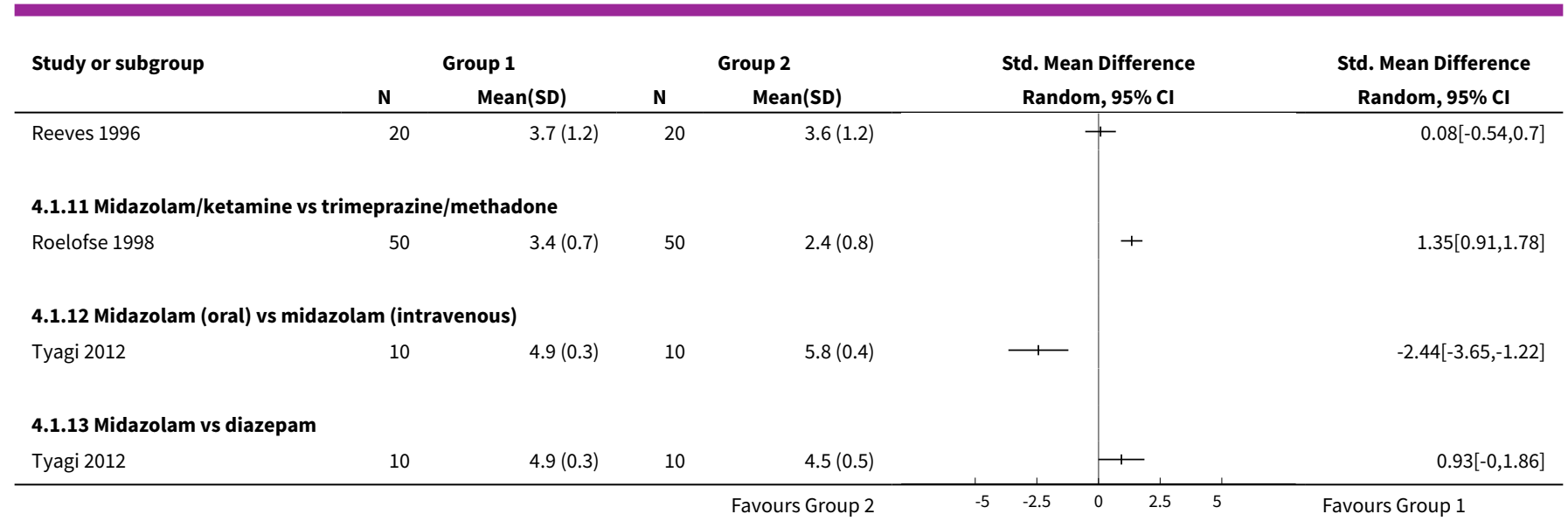

Analysis 4.2. Comparison 4 Midazolam (versus other), Outcome 2 Good or better sedation.

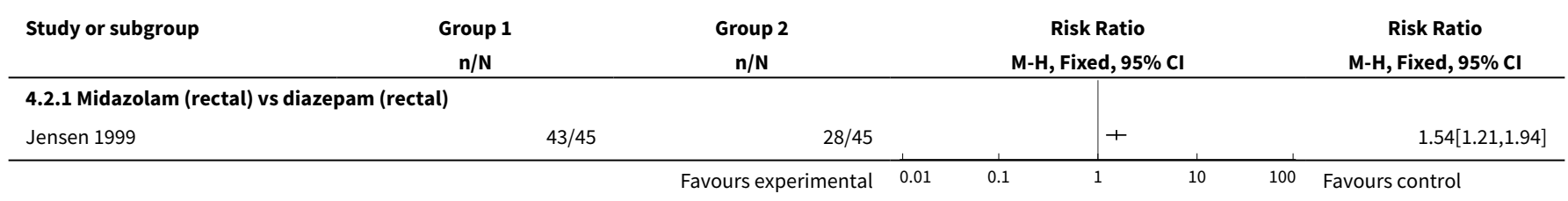

\section{Comparison 5. Nitrous oxide}

\begin{tabular}{|c|c|c|c|c|}
\hline Outcome or subgroup title & No. of studies & $\begin{array}{l}\text { No. of partici- } \\
\text { pants }\end{array}$ & Statistical method & Effect size \\
\hline $\begin{array}{l}1 \text { Overall behaviour (ordinal scale, } \\
\text { Houpt or similar) }\end{array}$ & 2 & & $\begin{array}{l}\text { Mean Difference (IV, Random, } \\
95 \% \mathrm{CI} \text { ) }\end{array}$ & $\begin{array}{l}\text { Totals not select- } \\
\text { ed }\end{array}$ \\
\hline 1.1 Nitrous oxide vs placebo & 1 & & $\begin{array}{l}\text { Mean Difference (IV, Random, } \\
95 \% \mathrm{CI} \text { ) }\end{array}$ & $0.0[0.0,0.0]$ \\
\hline 1.2 Nitrous oxide vs midazolam & 1 & & $\begin{array}{l}\text { Mean Difference (IV, Random, } \\
95 \% \mathrm{Cl} \text { ) }\end{array}$ & $0.0[0.0,0.0]$ \\
\hline
\end{tabular}

Analysis 5.1. Comparison 5 Nitrous oxide, Outcome 1 Overall behaviour (ordinal scale, Houpt or similar).

\begin{tabular}{|c|c|c|c|c|c|c|}
\hline \multirow[t]{2}{*}{ Study or subgroup } & \multicolumn{2}{|c|}{ Group 1} & \multicolumn{2}{|c|}{ Group 2} & \multirow{2}{*}{$\begin{array}{l}\text { Mean Difference } \\
\text { Random, 95\% Cl }\end{array}$} & \multirow{2}{*}{$\begin{array}{l}\text { Mean Difference } \\
\text { Random, } 95 \% \mathrm{CI}\end{array}$} \\
\hline & $\mathbf{N}$ & $\operatorname{Mean}(S D)$ & $\mathbf{N}$ & $\operatorname{Mean}(\mathrm{SD})$ & & \\
\hline \multicolumn{7}{|c|}{ 5.1.1 Nitrous oxide vs placebo } \\
\hline Veerkamp 1993 & 28 & $2.4(1.3)$ & 28 & $3.5(1.1)$ & & $-1.05[-1.69,-0.41]$ \\
\hline \multicolumn{7}{|c|}{ 5.1.2 Nitrous oxide vs midazolam } \\
\hline \multirow[t]{2}{*}{ Baygin 2010} & 15 & $1.7(0.6)$ & 15 & $2.3(0.8)$ & & $-0.57[-1.08,-0.06]$ \\
\hline & & & & avours Group $2 \quad-100$ & -50 & Favours Group 1 \\
\hline
\end{tabular}


ADDITIONALTABLES

Table 1. Placebo study outcomes

\begin{tabular}{|c|c|c|c|c|c|}
\hline Study ID & Sample & Intervention & Outcomes & Results & $\begin{array}{l}\text { Treatment } \\
\text { completed }\end{array}$ \\
\hline \multicolumn{6}{|c|}{ Chloral hydrate } \\
\hline Moore 1984 & $\begin{array}{l}\mathrm{n}=60 \\
\text { Group } 1 \text { ( } \mathrm{n}= \\
\text { 15), mean age } \\
3.6 \text { years, } 11 \\
\text { males, } 4 \text { fe- } \\
\text { males } \\
\text { Group } 2 \text { ( } \mathrm{n}= \\
\text { 15), mean age } \\
3.3 \text { years, } 7 \\
\text { males, } 8 \text { fe- } \\
\text { males } \\
\text { Group } 3 \text { ( } \mathrm{n} \\
=15), \text { mean } \\
\text { age } 3.8 \text { years, } \\
9 \text { males, } 6 \text { fe- } \\
\text { males } \\
\text { Group } 4 \text { ( } \mathrm{n} \\
=15 \text { ), mean } \\
\text { age } 3.9 \text { years, } \\
7 \text { males, } 8 \text { fe- } \\
\text { males }\end{array}$ & $\begin{array}{l}\text { Group 1: } \\
\text { placebo } \\
\text { Group 2: chlo- } \\
\text { ral hydrate (20 } \\
\mathrm{mg} / \mathrm{kg} \text { ) } \\
\text { Group 3: chlo- } \\
\text { ral hydrate (40 } \\
\mathrm{mg} / \mathrm{kg} \text { ) } \\
\text { Group 4: chlo- } \\
\text { ral hydrate (60 } \\
\mathrm{mg} / \mathrm{kg} \text { ) } \\
\text { All oral }\end{array}$ & $\begin{array}{l}\text { Behaviour } \\
\text { evaluations } \\
\text { Completion of } \\
\text { treatment } \\
\text { Analysed us- } \\
\text { ing Chi }{ }^{2} \text { and } \\
\text { Fisher's exact } \\
\text { test }\end{array}$ & $\begin{array}{l}\text { No statistically significant difference }(\mathrm{P}< \\
0.05) \text { seen between placebo and } 60 \mathrm{mg} / \mathrm{kg} \\
\text { chloral hydrate group for outcome of posi- } \\
\text { tive behaviour in operatory. No statistical- } \\
\text { ly significant differences between placebo } \\
\text { and other groups } \\
\text { Data reported as numbers and percentage } \\
\text { per group, at different stages of the treat- } \\
\text { ment and displayed in graphical form } \\
\text { Adverse effects: not clear, } 4 \text { children failed } \\
\text { to respond to obstruction (Group 4) after } \\
\text { nitrous oxide/oxygen started } \\
\text { Monitoring: cardiovascular and respiratory } \\
\text { monitoring mentioned }\end{array}$ & $\begin{array}{l}\text { All partici- } \\
\text { pants com- } \\
\text { pleted treat- } \\
\text { ment }\end{array}$ \\
\hline
\end{tabular}

\section{Dexmedetomidine (intranasal)}

\begin{tabular}{|c|c|c|c|c|}
\hline Malhotra 2016 & $\begin{array}{l}\mathrm{n}=36 \\
\begin{array}{l}\text { Age range }=3-9 \\
\text { years }\end{array} \\
\text { Mean age (SD) } \\
\text { in years: } 4.60 \pm \\
1.99 \\
\text { Mean weight } \\
\text { (SD) kg: } 15.62 \pm \\
4.21\end{array}$ & $\begin{array}{l}\text { Group 1: in- } \\
\text { tranasal nor- } \\
\text { mal saline, } \\
\text { oral midazo- } \\
\text { lam ( } 0.5 \mathrm{mg} / \\
\mathrm{kg} \text { ) oral ket- } \\
\text { amine }(5 \mathrm{mg} / \\
\mathrm{kg}) \text { in } 30 \mathrm{ml} \text { of } \\
\text { mango juice } \\
\text { Group 2: } \\
\text { intranasal } \\
\text { dexmedeto- } \\
\text { midine (1 } \mathrm{\mu} / \\
\text { kg), } 30 \text { ml of } \\
\text { mango juice } \\
\text { Group } 3: \text { in- } \\
\text { tranasal nor- } \\
\text { mal saline, } 30 \\
\text { ml of mango } \\
\text { juice }\end{array}$ & $\begin{array}{l}\text { Modified Ob- } \\
\text { server As- } \\
\text { sessment } \\
\text { of Alertness } \\
\text { and Sedation } \\
\text { (MOAAS) } \\
\text { Houpt scale }\end{array}$ & $\begin{array}{l}\text { Significant difference ( } P=0.007) \text { in behav- } \\
\text { iour during treatment compared to base- } \\
\text { line in Group } 1 \text { and Group } 2 \\
\text { Significant difference in the level of seda- } \\
\text { tion in Group } 1 \text { and Group } 2 \text { when a com- } \\
\text { parison is made at specific time stages } \\
\text { (treatment-baseline and end of treat- } \\
\text { ment-baseline) (e.g. for Group } 1 \text { treat- } \\
\text { ment-baseline comparison shows signifi- } \\
\text { cant difference ( } P=0.002) \text { in the level of se- } \\
\text { dation) } \\
\text { No significant difference between Group } 1 \\
\text { and Group } 2 \text { in sedative efficacy or anxioly- } \\
\text { sis potential } \\
\text { Adverse effects: not reported } \\
\text { Monitoring: blood pressure, heart rate, } \\
\text { oxygen saturation }\end{array}$ \\
\hline
\end{tabular}

Diazepam (oral) 
Table 1. Placebo study outcomes (Continued)

\begin{tabular}{|c|c|c|c|}
\hline Tyagi 2012 & $\begin{array}{l}\mathrm{n}=40 \\
\text { Age range = } \\
2-10 \text { years }\end{array}$ & $\begin{array}{l}\text { Group 1: oral } \\
\text { midazolam } \\
(0.5 \mathrm{mg} / \mathrm{kg}) \\
\text { Group 2: oral } \\
\text { diazepam } \\
(0.5 \mathrm{mg} / \mathrm{kg}) \\
\text { Group 3: in- } \\
\text { travenous mi- } \\
\text { dazolam (0.06 } \\
\text { mg/kg) } \\
\text { Group 4: } \\
\text { placebo }\end{array}$ & $\begin{array}{l}\text { Houpt scale } \\
\text { Child behav- } \\
\text { iour question } \\
\text { naire }\end{array}$ \\
\hline
\end{tabular}

Behaviour was assessed in terms of sleep, crying and movement at 30 minutes post drug administration in Group 1, Group 2 and Group 4 or 5 minutes in Group 3. At placement of blood pressure cuff, during administration of local anaesthesia or use of hand piece and every 15 minutes thereafter (e.g. at administration of local anaesthetic agent or use of hand piece significantly lower $(P<0.001)$ sleep in Group 4 compared to other groups. Significantly less crying in Group 3 compared to Group 1 , Group 2 and Group $4(P<0.001, P<0.01$ and $\mathrm{P}<0.05$ respectively))

Overall behaviour rating was significantly better $(P<0.001)$ in Group 3 compared to other groups

Positive behaviour post sedation: no significant difference between Group 1 and Group 2. Significant improvement $(\mathrm{P}<$ 0.05 ) in Group 3 compared to Group 2

Sleeping mentioned

Adverse effects: not reported

Monitoring: oxygen saturation, respiratory rate, blood pressure and respiratory rate

\section{Melatonin}

\begin{tabular}{|c|c|c|c|c|}
\hline Isik 2008a & $\begin{array}{l}\text { Mean age (SD) } \\
\text { in years, gen- } \\
\text { der, mean } \\
\text { weight (SD) in } \\
\text { kg: } \\
\text { Group 1: } \mathrm{n}= \\
15,4.87 \text { (0.99), } \\
7 \text { males, } 8 \mathrm{fe}- \\
\text { males, } 18.87 \\
(2.5) \\
\text { Group } 2: \mathrm{n}= \\
15,4.93(1.11) \text {, } \\
7 \text { males, } 8 \mathrm{fe}- \\
\text { males, } 17.87 \\
(3.88) \\
\text { Group } 3: \mathrm{n}= \\
15,4.93(1.10) \text {, } \\
8 \text { males, } 7 \mathrm{fe}- \\
\text { males, } 18.6 \\
(3.31) \\
\text { Group } 4: \mathrm{n}= \\
15,5.01(1.03) \text {, } \\
9 \text { males, } 6 \mathrm{fe}-\end{array}$ & $\begin{array}{l}\text { Group 1: } \\
\text { melatonin (3 } \\
\text { mg) } \\
\text { Group 2: } \\
\text { melatonin (0.5 } \\
\text { mg/kg) } \\
\text { Group 3: mi- } \\
\text { dazolam (0.75 } \\
\text { mg/kg) } \\
\text { Group 4: } \\
\text { placebo } \\
\text { All oral }\end{array}$ & $\begin{array}{l}\text { Ramsay Seda- } \\
\text { tion Score } \\
\text { Analysed with } \\
\text { Kruskal-Wallis }\end{array}$ & $\begin{array}{l}\text { Ramsay Sedation Score sign } \\
\text { er (i.e. more sedated) for Grc } \\
\text { all other groups ( } P<0.05) \text {. S } \\
\text { icantly likely to be scored as } \\
\text { in Group } 3 \text { versus other grou } \\
\text { Data presented graphically. } \\
\text { scored as unsatisfactory in } \\
\text { Adverse effects: vomiting, hi } \\
\text { coughing seen in all groups, } \\
\text { ported in Group } 3 \\
\text { Monitoring: pulse oximeter }\end{array}$ \\
\hline
\end{tabular}


Table 1. Placebo study outcomes (Continued)

males, 19.73

(4.77)

\section{Meperidine}

\begin{tabular}{|c|c|c|c|c|c|}
\hline McKee 1990 & $\begin{array}{l}\mathrm{n}=60 \\
\text { Mean age (SE) } \\
\text { in months: } \\
\text { Group 1: } \mathrm{n}=15, \\
36.5(2.7) \\
\text { Group 2: } \mathrm{n}=15, \\
41.7(3) \\
\text { Group 3: } \mathrm{n}=15, \\
35.9(2.7) \\
\text { Group 4: } \mathrm{n}=15, \\
43(2.7)\end{array}$ & $\begin{array}{l}\text { Group 1: } \\
\text { placebo } \\
\text { Group 2: } \\
\text { meperidine } \\
\text { (0.25 mg/lb) } \\
\text { Group 3: } \\
\text { meperidine } \\
(0.50 \mathrm{mg} / \mathrm{lb}) \\
\text { Group 4: } \\
\text { meperidine (1 } \\
\text { mg/lb) } \\
\text { All intramus- } \\
\text { cular }\end{array}$ & 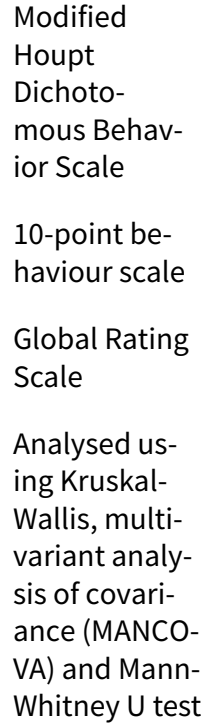 & $\begin{array}{l}\text { Global rating scale (good to excellent) sig- } \\
\text { nificantly favoured meperidine compared } \\
\text { to placebo. All doses of meperidine were } \\
\text { significantly better than placebo ( } P<0.05 \text { ) } \\
\text { for values of global sedation scale. All } 3 \\
\text { scales significantly contributed to overall } \\
\text { MANCOVA. Global rating reported as indi- } \\
\text { vidual frequencies } \\
\text { Sleep mentioned } \\
\text { Adverse effects: sleep/drowsiness (Groups } \\
1 \text { and 3), nausea/vomiting (Groups } 3 \text { and } \\
4 \text { ), hyperexcited (Group 3) } \\
\text { Monitoring: precordial stethoscope, auto- } \\
\text { matic sphygmomanometer, pulse oxime- } \\
\text { ter }\end{array}$ & $\begin{array}{l}1 \text { participant } \\
\text { from } 0.25 \mathrm{mg} / \\
\text { lb group and } 1 \\
\text { from } 0.5 \mathrm{mg} / \\
\text { lb group be- } \\
\text { came unman- } \\
\text { ageable and } \\
\text { treatment was } \\
\text { not complet- } \\
\text { ed }\end{array}$ \\
\hline
\end{tabular}

\section{Midazolam (intravenous)}

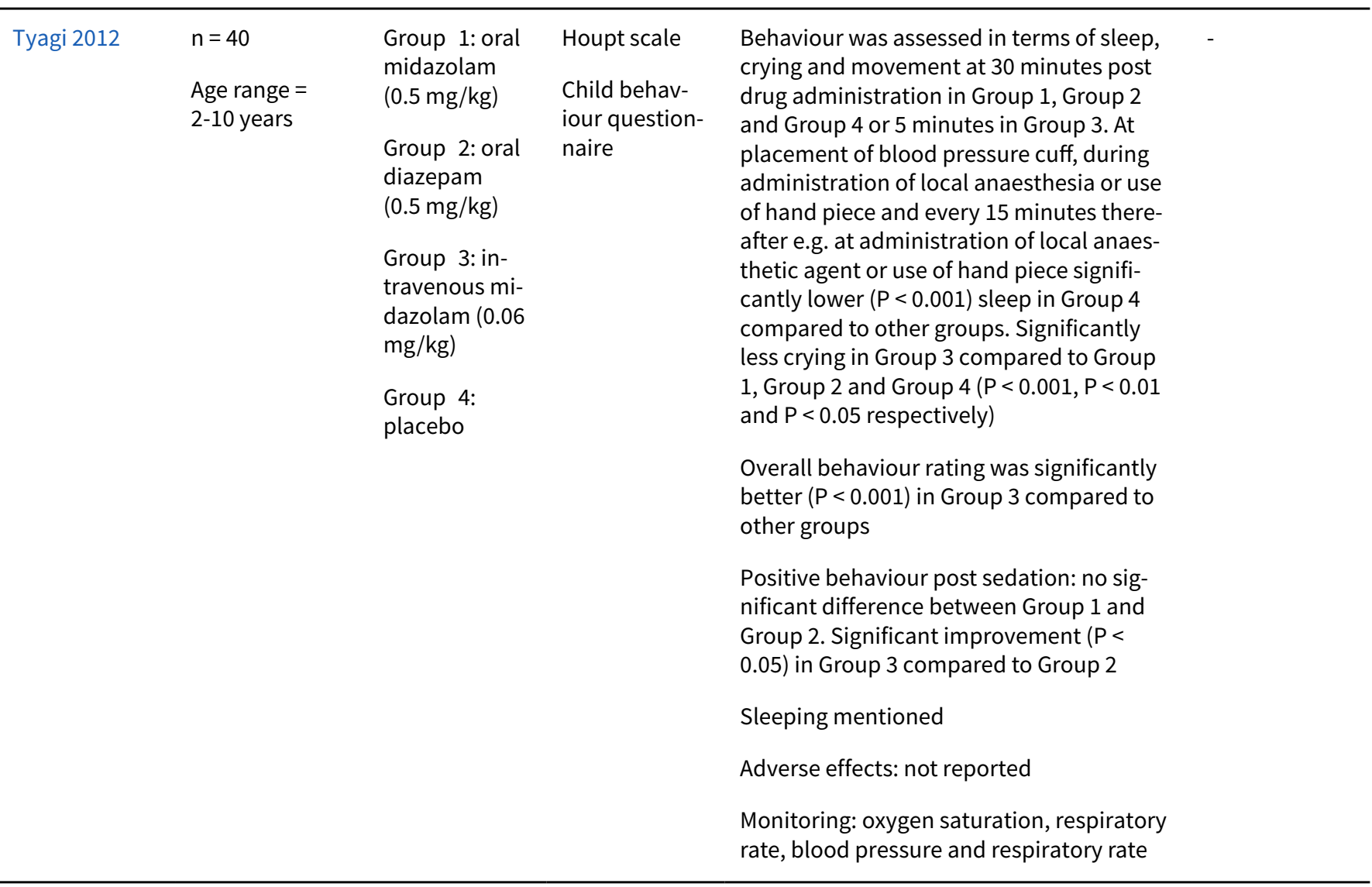

\section{Midazolam (oral)}




\section{Table 1. Placebo study outcomes (Continued)}

$\begin{array}{llll}\text { Gallardo } 1994 & \mathrm{n}=32 & \text { Group 1: mi- } & \text { Overall seda- } \\ \text { Age range }=4 & \text { dazolam (7.5 } & \text { tion mental } \\ \text { to 10 years } & \text { mg) (regard- } & \text { attitude } \\ 17 \text { males and } & \text { less of weight) } & \text { Hypnotic ef- } \\ 15 \text { females } & \text { Group 2: } & \text { fects } \\ & \text { placebo } & \text { Motor activity } \\ & \text { All oral } & \text { Ease of treat- } \\ & & \text { ment } \\ & & \text { Analysed us- } \\ & & \text { ing Wilcoxon } \\ & & \text { rank }\end{array}$

\begin{tabular}{|c|c|c|c|c|c|}
\hline Isik 2008a & $\begin{array}{l}\text { Mean age (SD) } \\
\text { in years, gen- } \\
\text { der, mean } \\
\text { weight (SD) in } \\
\mathrm{kg}: \\
\text { Group } 1: \mathrm{n}= \\
15,4.87 \text { (0.99), } \\
7 \text { males, } 8 \mathrm{fe}- \\
\text { males, } 18.87 \\
(2.5) \\
\text { Group } 2: \mathrm{n}= \\
15,4.93(1.11) \\
7 \text { males, } 8 \mathrm{fe}- \\
\text { males, } \\
17.87 \text { (3.88) } \\
\text { Group } 3: \mathrm{n}= \\
15,4.93(1.10) \text {, } \\
8 \text { males, } 7 \mathrm{fe}- \\
\text { males, } 18.6 \\
(3.31) \\
\text { Group } 4: \mathrm{n}= \\
15,5.01(1.03) \text {, } \\
9 \text { males, } 6 \mathrm{fe}- \\
\text { males, } 19.73 \\
(4.77)\end{array}$ & $\begin{array}{l}\text { Group 1: } \\
\text { melatonin (3 } \\
\text { mg) } \\
\text { Group 2: } \\
\text { melatonin (0.5 } \\
\text { mg/kg) } \\
\text { Group 3: mi- } \\
\text { dazolam (0.75 } \\
\text { mg/kg) } \\
\text { Group 4: } \\
\text { placebo } \\
\text { All oral }\end{array}$ & $\begin{array}{l}\text { Ramsay Seda- } \\
\text { tion Score } \\
\text { Analysed with } \\
\text { Kruskal-Wallis }\end{array}$ & $\begin{array}{l}\text { Ramsay Sedation Score significantly high- } \\
\text { er (i.e. more sedated) for Group } 3 \text { versus } \\
\text { all other groups }(P<0.05) \text {. Sedation signif- } \\
\text { icantly likely to be scored as satisfactory } \\
\text { in Group } 3 \text { versus other groups }(P<0.05) \text {. } \\
\text { Data presented graphically. No sedations } \\
\text { scored as unsatisfactory in Group } 3 \\
\text { Adverse effects: vomiting, hiccupping and } \\
\text { coughing seen in all groups, amnesia re- } \\
\text { ported in Group } 3 \\
\text { Monitoring: pulse oximeter }\end{array}$ & - \\
\hline Kapur 2004 & $\begin{array}{l}\mathrm{n}=40 \\
\text { Age: younger } \\
\text { than } 4 \text { years old } \\
\text { - no differences } \\
\text { at baseline with } \\
\text { regards to age, } \\
\text { sex and body } \\
\text { weight }\end{array}$ & $\begin{array}{l}\text { Group 1: mi- } \\
\text { dazolam (0.5 } \\
\mathrm{mg} / \mathrm{kg} \text { ) (oral/ } \\
\text { transmucosal) } \\
\text { Group 2: } \\
\text { placebo } \\
\text { (same vol- } \\
\text { ume) }\end{array}$ & $\begin{array}{l}\text { Sedation } \\
\text { score, treat- } \\
\text { ment comple- } \\
\text { tion, time } \\
\text { No statisti- } \\
\text { cal tests de- } \\
\text { scribed }\end{array}$ & $\begin{array}{l}\text { Significantly better sedation in Group } 1 \\
\text { (mean 3.75, SD 0.85) compared to Group } 2 \\
\text { (mean 4.6, SD } 0.5)(P<0.01) .18 \text { completed } \\
\text { Group } 1 \text { versus } 7 \text { Group } 2(P<0.01) \\
\text { Monitored with pulse oximeter }\end{array}$ & - \\
\hline $\begin{array}{l}\text { Mortazavi } \\
2009\end{array}$ & $\begin{array}{l}\mathrm{n}=40 \\
\text { Mean age (SD) } \\
\text { years: } 3.99 \\
(0.38)\end{array}$ & $\begin{array}{l}\text { Group 1: } \\
\text { placebo } \\
\text { Group 2: mi- } \\
\text { dazolam }(0.25 \\
\mathrm{mg} / \mathrm{kg}) \\
\text { All oral }\end{array}$ & $\begin{array}{l}\text { Houpt } \\
\text { Analysed us- } \\
\text { ing Mann- } \\
\text { Whitney U test }\end{array}$ & $\begin{array}{l}\text { Significant improvement in overall be- } \\
\text { haviour in midazolam group compared to } \\
\text { placebo group ( } 5.1 \text { versus } 1.6, \mathrm{P}<0.05) \\
\text { Adverse effects: none } \\
\text { Monitoring: pulse oximeter, precordial } \\
\text { stethoscope }\end{array}$ & $\begin{array}{l}11 \text { out of } \\
20 \text { patients } \\
\text { aborted treat- } \\
\text { ment in place- } \\
\text { bo group }\end{array}$ \\
\hline
\end{tabular}

Midazolam significantly better than placebo $(P<0.001)$ in all categories. Data presented graphically

Sleeping mentioned

Adverse effects and monitoring: not mentioned 
Table 1. Placebo study outcomes (Continued)

\begin{tabular}{|c|c|c|c|c|c|}
\hline Moreira 2013 & $\begin{array}{l}\mathrm{n}=44 \\
\text { Average age be- } \\
\text { low } 36 \text { months } \\
\text { Mean age (SD) } \\
\text { in months, gen- } \\
\text { der: } \\
\text { Group } 1: \mathrm{n}= \\
11,27.1(8.3) \text {, } \\
6 \text { males, } 5 \text { fe- } \\
\text { males } \\
\text { Group } 2: \mathrm{n}= \\
18 \text { (parents re- } \\
\text { fused treat- } \\
\text { ment for } 2 \text { ), } \\
27.7(5.5), 9 \\
\text { males, } 7 \text { fe- } \\
\text { males } \\
\text { Group } 3: \mathrm{n}= \\
15 \text { (parents re- } \\
\text { fused treat- } \\
\text { ment for } 1 \text { ), } \\
27.3(6.4), 9 \\
\text { males, } 4 \text { fe- } \\
\text { males }\end{array}$ & $\begin{array}{l}\text { Group 1: mi- } \\
\text { dazolam (0.5 } \\
\mathrm{mg} / \mathrm{kg})+ \text { ket- } \\
\text { amine (3 mg/ } \\
\mathrm{kg}) \\
\text { Group 2: mi- } \\
\text { dazolam (1 } \\
\text { mg/kg) } \\
\text { Group 3: no } \\
\text { sedation } \\
\text { Group } 1 \text { and } 2 \\
\text { oral }\end{array}$ & $\begin{array}{l}\text { Ohio State } \\
\text { University Be- } \\
\text { havior Rat- } \\
\text { ing Scale } \\
\text { (OSUBRS) }\end{array}$ & $\begin{array}{l}\text { Significant difference in behaviour ( } \mathrm{P}= \\
0.003 \text { ) between Group } 1 \text { and Group } 2 \text { and } \\
\text { Group } 1 \text { and Group } 3(\mathrm{P}=0.03 \text { ) when seda- } \\
\text { tives used } \\
\text { Behaviour during various stages of treat- } \\
\text { ment sessions was observed e.g. for local } \\
\text { anaesthetic administration OSUBRS score } \\
\text { for Group } 1 \text { was lower than Group } 2 \text { ( } P= \\
0.06 \text { ) and Group } 3(\mathrm{P}=0.02 \text { ) } \\
\text { During rubber dam placement OSUBRS } \\
\text { score for Group } 1 \text { was lower than Group } 2 \\
\text { ( } P=0.01 \text { ) and Group } 3 \text { ( } P=0.07) \text {. All groups } \\
\text { showed same behavioural pattern at the } \\
\text { end of the treatment session ( } P=0.25 \text { ) } \\
\text { Sleep mentioned } \\
\text { Adverse effects: within } 24 \text { hours post-op- } \\
\text { eratively Group } 1 \text { presented with agitation } \\
\text { and vomiting in } 3 \text { children }\end{array}$ & $\begin{array}{l}\text { All partici- } \\
\text { pants com- } \\
\text { pleted treat- } \\
\text { ment }\end{array}$ \\
\hline Tyagi 2012 & $\begin{array}{l}\mathrm{n}=40 \\
\text { Age range = } \\
2-10 \text { years }\end{array}$ & $\begin{array}{l}\text { Group 1: oral } \\
\text { midazolam } \\
(0.5 \mathrm{mg} / \mathrm{kg}) \\
\text { Group 2: oral } \\
\text { diazepam } \\
(0.5 \mathrm{mg} / \mathrm{kg}) \\
\text { Group 3: in- } \\
\text { travenous mi- } \\
\text { dazolam }(0.06 \\
\text { mg/kg) } \\
\text { Group 4: } \\
\text { placebo }\end{array}$ & $\begin{array}{l}\text { Houpt scale } \\
\text { Child behav- } \\
\text { iour question- } \\
\text { naire }\end{array}$ & $\begin{array}{l}\text { Behaviour was assessed in terms of sleep, } \\
\text { crying and movement at } 30 \text { minutes post } \\
\text { drug administration in Group } 1 \text {, Group } 2 \\
\text { and Group } 4 \text { or } 5 \text { minutes in Group } 3 \text {. At } \\
\text { placement of blood pressure cuff, during } \\
\text { administration of local anaesthesia or use } \\
\text { of hand piece and every } 15 \text { minutes there- } \\
\text { after e.g. at administration of local anaes- } \\
\text { thetic agent or use of hand piece signifi- } \\
\text { cantly lower ( } P \text { < } 0.001 \text { ) sleep in Group } 4 \\
\text { compared to other groups. Significantly } \\
\text { less crying in Group } 3 \text { compared to Group } \\
1, \text { Group } 2 \text { and Group } 4 \text { ( } P<0.001, P<0.01 \\
\text { and } P<0.05 \text { respectively) } \\
\text { Overall behaviour rating was significantly } \\
\text { better ( } P<0.001 \text { in Group } 3 \text { compared to } \\
\text { other groups } \\
\text { Positive behaviour post sedation: no sig- } \\
\text { nificant difference between Group } 1 \text { and } \\
\text { Group } 2 . \text { Significant improvement ( } P< \\
0.05) \text { in Group } 3 \text { compared to Group } 2 \\
\text { Sleeping mentioned } \\
\text { Adverse effects: not reported } \\
\text { Monitoring: oxygen saturation, respiratory } \\
\text { rate, blood pressure and respiratory rate }\end{array}$ & - \\
\hline
\end{tabular}


Table 1. Placebo study outcomes (Continued)

$\begin{array}{llll}\text { Wan } 2006 & \mathrm{n}=40 & \begin{array}{l}\text { Group 1: } \\ \text { placebo }\end{array} & \text { Ramsey } \\ \text { Group 1: } \mathrm{n}=19 & \begin{array}{l}\text { Group 2: mi- } \\ \text { dazolam }(0.5 \\ \mathrm{mg} / \mathrm{kg})\end{array} & \begin{array}{l}\text { Brietkopf and } \\ \text { Buttner scale }\end{array} \\ \begin{array}{l}\text { Mean age } \\ \text { (range) in years }\end{array} & \text { All oral } & \text { Frankl scale } \\ \begin{array}{l}\text { all subjects: } 7.3 \\ \text { (5-10) }\end{array} & & \text { Houpt scale } \\ & \begin{array}{l}\text { Mean weight } \\ \text { (range) in kg all } \\ \text { subjects: }\end{array} & & \text { ing 1-way } \\ & & \end{array}$

Scores significantly lower in placebo group for all outcomes $(P<0.001)$

Adverse effects: 15 subjects reported amnesia - all in the midazolam group Monitoring: blood pressure, pulse oximeter

$22.9(16-32)$

\section{Midazolam and ketamine (oral)}

\begin{tabular}{|c|c|c|c|c|c|}
\hline Malhotra 2016 & $\begin{array}{l}\mathrm{n}=36 \\
\begin{array}{l}\text { Age range }=3-9 \\
\text { years }\end{array} \\
\text { Mean age (SD) } \\
\text { in years: } 4.60 \pm \\
1.99 \\
\text { Mean weight } \\
\text { (SD) kg: } 15.62 \pm \\
4.21\end{array}$ & $\begin{array}{l}\text { Group 1: in- } \\
\text { tranasal nor- } \\
\text { mal saline, } \\
\text { oral midazo- } \\
\text { lam ( } 0.5 \mathrm{mg} / \\
\mathrm{kg})+ \text { oral ket- } \\
\text { amine }(5 \mathrm{mg} / \\
\mathrm{kg}) \text { in } 30 \mathrm{ml} \text { of } \\
\text { mango juice } \\
\text { Group 2: } \\
\text { intranasal } \\
\text { dexmedeto- } \\
\text { midine (1 } \mathrm{\mu} / \\
\mathrm{kg}), 30 \text { ml of } \\
\text { mango juice } \\
\text { Group } 3: \text { in- } \\
\text { tranasal nor- } \\
\text { mal saline, } 30 \\
\text { ml of mango } \\
\text { juice }\end{array}$ & $\begin{array}{l}\text { Modified Ob- } \\
\text { server As- } \\
\text { sessment } \\
\text { of Alertness } \\
\text { and Sedation } \\
\text { (MOAAS) } \\
\text { Houpt scale }\end{array}$ & $\begin{array}{l}\text { Significant difference }(\mathrm{P}=0.007) \text { in behav- } \\
\text { iour during treatment compared to base- } \\
\text { line in Group } 1 \text { and Group } 2 \\
\text { Significant difference in the level of seda- } \\
\text { tion in Group } 1 \text { and Group } 2 \text { when a com- } \\
\text { parison is made at specific time stages } \\
\text { (treatment-baseline and end of treat- } \\
\text { ment-baseline) e.g. for Group } 1 \text { treat- } \\
\text { ment-baseline comparison shows signifi- } \\
\text { cant difference ( } P=0.002) \text { in the level of se- } \\
\text { dation } \\
\text { No significant difference between Group } 1 \\
\text { and Group } 2 \text { in sedative efficacy or anxioly- } \\
\text { sis potential } \\
\text { Adverse effects: not reported } \\
\text { Monitoring: blood pressure, heart rate, } \\
\text { oxygen saturation }\end{array}$ & - \\
\hline Moreira 2013 & $\begin{array}{l}\mathrm{n}=44 \\
\text { Average age be- } \\
\text { low } 36 \text { months } \\
\text { Mean age (SD) } \\
\text { in months, gen- } \\
\text { der: } \\
\text { Group } 1: \mathrm{n}= \\
11,27.1(8.3) \\
6 \text { males, } 5 \text { fe- } \\
\text { males } \\
\text { Group } 2: \mathrm{n}= \\
18 \text { (parents re- } \\
\text { fused treat- } \\
\text { ment for } 2 \text { ), } \\
27.7 \text { (5.5), } 9\end{array}$ & $\begin{array}{l}\text { Group 1: mi- } \\
\text { dazolam (0.5 } \\
\mathrm{mg} / \mathrm{kg})+ \text { ket- } \\
\text { amine (3 mg/ } \\
\mathrm{kg} \text { ) } \\
\text { Group 2: mi- } \\
\text { dazolam (1 } \\
\text { mg/kg) } \\
\text { Group 3: no } \\
\text { sedation } \\
\text { Group } 1 \text { and } 2 \\
\text { oral }\end{array}$ & $\begin{array}{l}\text { Ohio State } \\
\text { University Be- } \\
\text { havior Rat- } \\
\text { ing Scale } \\
\text { (OSUBRS) }\end{array}$ & $\begin{array}{l}\text { Significant difference in behaviour ( } P= \\
0.003) \text { between Group } 1 \text { and Group } 2 \text { and } \\
\text { Group } 1 \text { and Group } 3(P=0.03 \text { ) when seda- } \\
\text { tives used } \\
\text { Behaviour during various stages of treat- } \\
\text { ment sessions was observed e.g. for local } \\
\text { anaesthetic administration OSUBRS score } \\
\text { for Group } 1 \text { was lower than Group } 2(P= \\
0.06 \text { ) and Group } 3(P=0.02) \\
\text { During rubber dam placement OSUBRS } \\
\text { score for Group } 1 \text { was lower than Group } 2 \\
\text { (P=0.01) and Group } 3(P=0.07) \text {. All Groups } \\
\text { showed same behavioural pattern at the } \\
\text { end of the treatment session }(P=0.25) \\
\text { Sleep mentioned }\end{array}$ & $\begin{array}{l}\text { All partici- } \\
\text { pants com- } \\
\text { pleted treat- } \\
\text { ment }\end{array}$ \\
\hline
\end{tabular}


Table 1. Placebo study outcomes (Continued)

males, $7 \mathrm{fe}$ -

males

Group 3: $\mathrm{n}=$

15 (parents re-

fused treat-

ment for 1$)$,

$27.3(6.4), 9$

males, 4 fe-

males
Adverse effects: within 24 hours post-operatively Group 1 presented with agitation and vomiting in 3 children

\begin{tabular}{|c|c|c|c|c|c|}
\hline \multicolumn{6}{|l|}{ Nitrous oxide } \\
\hline Nathan 1988 & $\begin{array}{l}\mathrm{n}=35 \\
\text { Age range }=48 \\
\text { to } 72 \text { months }\end{array}$ & $\begin{array}{l}\text { Group 1: no } \\
\text { intervention } \\
\text { Group 2: } \\
\text { placebo } \\
\text { inhalation } \\
\text { Group 3: } \\
\text { 20-50:50 ni- } \\
\text { trous ox- } \\
\text { ide/oxygen } \\
\text { inhalation }\end{array}$ & $\begin{array}{l}\text { Venham } \\
\text { Parental } \\
\text { questionnaire } \\
\text { Behavioral } \\
\text { screening in- } \\
\text { strument } \\
\text { Ratings of } \\
\text { anxiety and } \\
\text { behaviour } \\
\text { analysed us- } \\
\text { ing 2-way } \\
\text { ANOVA }\end{array}$ & $\begin{array}{l}\text { Significantly lower anxiety and behaviour } \\
\text { ratings in nitrous oxide group }(\mathrm{P}<0.05) \text {. } \\
\text { Data presented graphically } \\
\text { Adverse effects: not mentioned Monitoring: } \\
\text { precordial electrodes: heart rate using Ep- } \\
\text { stein's measure of mean heart rate }\end{array}$ & $\begin{array}{l}\text { All partici- } \\
\text { pants com- } \\
\text { pleted treat- } \\
\text { ment }\end{array}$ \\
\hline $\begin{array}{l}\text { Veerkamp } \\
1993\end{array}$ & $\begin{array}{l}\mathrm{n}=56 \\
\text { Group 1: } \mathrm{n}=27 \\
\text { Group 2: } \mathrm{n}=29 \\
\text { Age range all } \\
\text { subjects }=6 \text { to } \\
11 \text { years }\end{array}$ & $\begin{array}{l}\text { Group 1: be- } \\
\text { haviour man- } \\
\text { agement } \\
\text { Group 2: up to } \\
\text { 40:60 nitrous } \\
\text { oxide/oxygen } \\
\text { All inhalation }\end{array}$ & $\begin{array}{l}\text { Venham scale } \\
\text { Analysed us- } \\
\text { ing t-test }\end{array}$ & $\begin{array}{l}\text { Mean Venham scores from T1 p177 trans- } \\
\text { formed for forest plots } \\
\text { Significantly better outcome }(P<0.05) \text { in } \\
\text { nitrous oxide group (mean overall score } \\
\text { Group } 1=2.84, \text { SD } 0.80, \text { Group } 2=3.45, S D \\
0.92 \text { ) } \\
\text { Adverse effects and monitoring not men- } \\
\text { tioned }\end{array}$ & $\begin{array}{l}\text { All partici- } \\
\text { pants com- } \\
\text { pleted treat- } \\
\text { ment }\end{array}$ \\
\hline
\end{tabular}

ANOVA = analysis of variance; MANCOVA = multivariant analysis of covariance; $\mathrm{n}=$ number; $\mathrm{SD}=$ standard deviation; $\mathrm{SE}=$ standard error .

Table 2. Dosage study outcomes

\begin{tabular}{|c|c|c|c|c|c|}
\hline Study ID & Sample & Intervention & Outcomes & Outcome results & $\begin{array}{l}\text { Treatment } \\
\text { completed }\end{array}$ \\
\hline \multicolumn{6}{|c|}{ Hydroxyzine } \\
\hline $\begin{array}{l}\text { Faytrouny } \\
2007\end{array}$ & $\begin{array}{l}\mathrm{n}=30 \\
14 \text { females, } 16 \\
\text { males } \\
\text { Mean age (SD) } \\
\text { months: } \\
\text { Group 1 } \\
61.9 \text { (11.9) } \\
\text { Group 2 }\end{array}$ & $\begin{array}{l}\text { Group 1: hy- } \\
\text { droxyzine ( } 20 \\
\text { mg } 24 \text { hours } \\
\text { before) + hy- } \\
\text { droxyzine ( } 3.7 \\
\text { mg/kg at the } \\
\text { appointment) } \\
\text { Group 2: hy- } \\
\text { droxyzine (3.7 } \\
\text { mg/kg at the } \\
\text { appointment) }\end{array}$ & $\begin{array}{l}\text { Houpt. } \\
\text { Analysed us- } \\
\text { ing ANOVA } \\
\text { and Mann- } \\
\text { Whitney }\end{array}$ & $\begin{array}{l}\text { No significant differences at any time } \\
\text { point. At } 20 \text { minutes Houpt Group 1, } 5.2 \\
\text { (SD 1.5) and Group 2, } 4.6 \text { (SD 1.6) } \\
\text { No adverse effects reported in either } \\
\text { group } \\
\text { Monitoring: pulse oximeter }\end{array}$ & - \\
\hline
\end{tabular}


Table 2. Dosage study outcomes (Continued)

53.7 (12.8) All oral

\begin{tabular}{|c|c|c|c|c|c|}
\hline \multicolumn{6}{|c|}{ Midazolam (intranasal) } \\
\hline Al-Rakaf 2001 & $\begin{array}{l}\mathrm{n}=38 \text { children } \\
\text { Mean age }(S D) \\
\text { in years and gen- } \\
\text { der: } \\
\text { Group } 1(\mathrm{n}=12) \\
3.75(0.75), 6 \\
\text { males, } 6 \text { females } \\
\text { Group } 2(\mathrm{n}=13) \\
4.3(0.65), 6 \\
\text { males, } 7 \text { females } \\
\text { Group } 3(\mathrm{n}=13) \\
4 \text { (0.71), } 6 \text { males, } \\
7 \text { females }\end{array}$ & $\begin{array}{l}\text { Group 1: mi- } \\
\text { dazolam (0.3 } \\
\text { mg/kg) } \\
\text { Group 2: mi- } \\
\text { dazolam (0.4 } \\
\text { mg/kg) } \\
\text { Group 3: mi- } \\
\text { dazolam (0.5 } \\
\text { mg/kg) } \\
\text { All intranasal }\end{array}$ & $\begin{array}{l}\text { Houpt. } \\
\text { Analysed us- } \\
\text { ing Tukey's } \\
\text { range test and } \\
\text { non-paramet- } \\
\text { ric 2-factor } \\
\text { ANOVA } \\
\text { Duration of } \\
\text { sedation }\end{array}$ & $\begin{array}{l}\text { Significant difference in Houpt behaviour- } \\
\text { al scores between Group } 3 \text { and Group } 1 \\
(\mathrm{P}<0.0001) \text { and between Group } 3 \text { and } \\
\text { Group } 2(\mathrm{P}<0.01) \\
\text { No difference in outcomes between fast- } \\
\text { ing and no-fasting in each group ( } \mathrm{P}= \\
0.8286) \\
\text { None of the children were asleep } \\
\text { Adverse effects: sneezing and coughing } \\
\text { during administration and drowsiness } \\
\text { (Groups } 1 \text { and } 2 \text { ), diplopia (only in Group } \\
\text { 3) } \\
\text { Monitoring: pulse oximeter }\end{array}$ & $\begin{array}{l}79 \% 0.3 \mathrm{mg} / \\
\mathrm{kg}, 96 \% 0.4 \\
\mathrm{mg} / \mathrm{kg} \text { and } \\
100 \% 0.5 \mathrm{mg} / \\
\mathrm{kg} \text { completed } \\
\text { treatment }\end{array}$ \\
\hline Lam 2005 & $\begin{array}{l}\mathrm{n}=23 \text { (12 Group } \\
1,11 \text { Group 2) } \\
\text { Mean age (range) } \\
\text { in years: } 5.13 \\
(2-9) \\
\text { Mean weight } \\
\text { (range) in kg: } \\
21.74 \text { (12-30) } \\
15 \text { males, } 7 \text { fe- } \\
\text { males }\end{array}$ & $\begin{array}{l}\text { Group 1: mi- } \\
\text { dazolam (0.2 } \\
\mathrm{mg} / \mathrm{kg} \text { ) (intra- } \\
\text { muscular) } \\
\text { Group 2: mi- } \\
\text { dazolam (0.2 } \\
\mathrm{mg} / \mathrm{kg} \text { ) (in- } \\
\text { tranasal) } \\
\text { All used as } \\
\text { premed for } \\
\text { unspecified } \\
\text { intravenous } \\
\text { sedation drug }\end{array}$ & $\begin{array}{l}\text { Houpt. } \\
\text { Analysed us- } \\
\text { ing Mann- } \\
\text { Whitney. In- } \\
\text { ter-examiner } \\
\text { variability as- } \\
\text { sessed using } \\
\text { Spearmans } \\
\text { rank correla- } \\
\text { tion } \\
\text { Good/excel- } \\
\text { lent sedation } \\
\text { levels in each } \\
\text { group }\end{array}$ & $\begin{array}{l}\text { Patients more deeply sedated in Group } \\
1 \text { at time of local anaesthesia adminis- } \\
\text { tration and venepuncture ( } P<0.048, P \\
<0.015 \text { respectively). } 1 \text { observer found } \\
\text { Group } 1 \text { (intramuscular) significantly } \\
\text { more effective than Group } 2(\mathrm{P}<0.04) \text {. } \\
\text { Not significant for the second observer ( } \mathrm{P} \\
=0.056) \text {. Individual outcomes for each ob- } \\
\text { server not reported } \\
\text { Good/excellent sedation } 12 / 12(100 \%) \text { in } \\
\text { intramuscular group and } 6 / 11(54 \%) \text { in } \\
\text { the intranasal group } \\
\text { Children more likely to be drowsy in } \\
\text { Group } 1 \\
\text { Adverse effects: none reported } \\
\text { Monitoring: heart rate, respiratory rate, } \\
\text { blood pressure, oxygen saturation }\end{array}$ & $\begin{array}{l}\text { Treatment } \\
\text { completed } \\
\text { by all partici- } \\
\text { pants }\end{array}$ \\
\hline Lee-Kim 2004 & $\begin{array}{l}\mathrm{n}=40 \\
\text { Mean age (un- } \\
\text { clear, possibly } \\
\text { SD) in months; } \\
\text { mean weight } \\
\text { (unclear, pos- } \\
\text { sibly SD) in kg; } \\
\text { gender: } \\
\text { Group } 1 \text { ( } \mathrm{n}= \\
\text { 20) } 40.8(11), 17 \\
\text { (3.6), } 11 \text { males, } 9 \\
\text { females } \\
\text { Group } 2(\mathrm{n}=20) \\
38.5(9.8), 16.2\end{array}$ & $\begin{array}{l}\text { Group 1: mi- } \\
\text { dazolam (0.7 } \\
\text { mg/kg) (oral) } \\
\text { Group 2: mi- } \\
\text { dazolam (0.3 } \\
\text { mg/kg) (nasal) }\end{array}$ & $\begin{array}{l}\text { Modified } \\
\text { Houpt - do- } \\
\text { mains of sleep } \\
\text { movement } \\
\text { and crying } \\
\text { but no over- } \\
\text { all measure. } \\
\text { Analysed with } \\
\text { ANOVA, Chi2 } \\
\text { statistic and t- } \\
\text { test } \\
\text { Mean time } \\
\text { of onset and } \\
\text { mean working } \\
\text { time in each } \\
\text { group }\end{array}$ & $\begin{array}{l}\text { Data presented on graphs only and text } \\
\text { states no significant differences in Houpt } \\
\text { using multivariate ANOVA ( } P=0.749) \\
\text { Onset of sedation mean } 5.55 \text { minutes (SD } \\
2.2 \text { ) for nasal and mean } 15.5 \text { minutes (SD } \\
\text { 5) for oral ( } P<0.001) \\
\text { Mean working time was } 29.3 \text { minutes (SD } \\
\text { 11.6) for nasal and \& } 38.1 \text { min (SD 7.58) } \\
\text { for PO ( } P=0.007) \\
\text { Adverse effects: none reported, no differ- } \\
\text { ences between groups. } \\
\text { Monitoring: oxygen saturation, heart rate, } \\
\text { respiratory rate }\end{array}$ & $\begin{array}{l}\text { All partici- } \\
\text { pants com- } \\
\text { pleted }\end{array}$ \\
\hline
\end{tabular}


Table 2. Dosage study outcomes (Continued)

(4), 10 males, 10

females

\begin{tabular}{ll}
\hline $\begin{array}{l}\text { Shashikiran } \\
2006\end{array}$ & $\mathrm{n}=40$ \\
& Group 1: 11 \\
& males, 9 females, \\
& mean age (SD) \\
& in years 3.4 (0.6), \\
& mean weight \\
& (SD) in kg 12.2 \\
& $(1.2)$ \\
& Group 2: 8 males, \\
& 12 females, \\
& mean age (SD) \\
& in years 3.5 (0.7), \\
& mean weight \\
& (SD) in kg 12.6 \\
& $(1.4)$
\end{tabular}

$\begin{array}{llll}\text { Group 1: mi- } & \text { Houpt and } & \text { No difference in behaviour between } & \text { Score } 3 \text { given } \\ \text { dazolam }(0.2 & \text { Fukuta. } & \text { groups }(\mathrm{Chi}=0.37, \mathrm{P}=0.83), \text { but both } & \text { to excellent, } 2 \\ \mathrm{mg} / \mathrm{kg}) \text { (intra- } & \text { Analysed us- } & \text { groups showed improvement from base- } & \text { to satisfacto- } \\ \text { muscular) } & \text { ing Chi2 statis- } & \text { line. Intranasal midazolam was signifi- } & \text { ry, } 1 \text { to unsat- } \\ & \text { tic and Mann- } & \text { cantly faster acting at all time points and } & \text { isfactory }\end{array}$

Group 2: midazolam $(0.2$ $\mathrm{mg} / \mathrm{kg}$ ) (intranasal)

allowed a shorter treatment time overall $(P<0.001)$

Mean onset times $15.7 \pm 2.0$ minutes intramuscular versus $10.8 \pm 2.0$ minutes intranasal

Adverse effects: 2 patients in the intramuscular group and 6 patients in the intranasal group showed instances of sneezing/coughing/hiccups after the administration of the sedative (difference not statistically significant)

No fasting pretreatment and no vomiting in either group

Monitoring: heart rate, respiratory rate

\begin{tabular}{|c|c|c|}
\hline $\begin{array}{l}\text { Shanmugaav- } \\
\text { el } 2016 a\end{array}$ & $\begin{array}{l}n=20 \\
\text { Age range }=4-7 \\
\text { years }\end{array}$ & $\begin{array}{l}\text { Group 1: mi- } \\
\text { dazolam (0.2 } \\
\text { mg/kg) (in- } \\
\text { tranasal) }\end{array}$ \\
\hline & $\begin{array}{l}\text { Group } 1(n=10) \\
\text { Group } 2(n=10)\end{array}$ & $\begin{array}{l}\text { Group 2: } \mathrm{mi}- \\
\text { dazolam ( } 0.2 \\
\mathrm{mg} / \mathrm{kg}) \text { (sub- } \\
\text { lingual) }\end{array}$ \\
\hline
\end{tabular}

Venham's Significant decrease in anxiety in Group

Clinical Anxi- $\quad 1(P=0.004)$ and Group $2(P=0.0 .003) 20$ ety Scale minutes after drug administration

Salivary corti- Group 1 showed statistically significant sol level decrease in anxiety at each of the 4 points of measurement during operative procedure ( $\mathrm{T} 1, \mathrm{~T} 2, \mathrm{~T} 3, \mathrm{~T} 4)$, whereas Group 2 did not show statistically significant change at $\mathrm{T} 1, \mathrm{~T} 2$ and $\mathrm{T} 3$

No significant difference in salivary cortisol levels before and after drug administration in Group 1 and Group $2(\mathrm{P}=0.07, \mathrm{P}$ $=0.38$ respectively)

No significant correlation between decrease in clinical anxiety and salivary cortisol level in Group 1 and Group $2(\mathrm{P}=$ $0.554, \mathrm{P}=0.457$ respectively)

Adverse effects: not reported

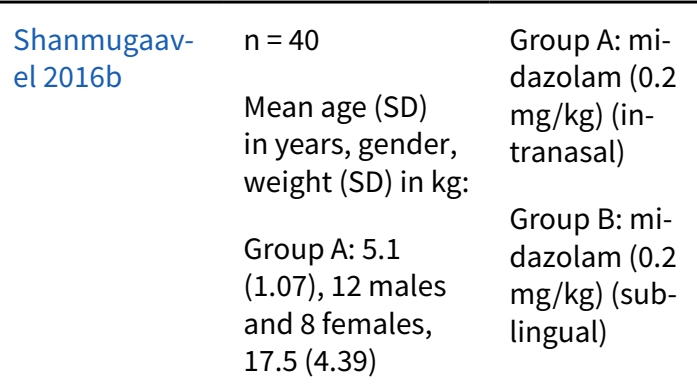
Venham's
Clinical Anxi- ety Scale
No statistically significant difference in Venham's anxiety score between groups at baseline or at the end time point (T4)
Acceptance
(Al-Rakaf
Mean (SD) Venham's score at T4 in Group A 0.35 (0.59) and Group B 0.45 (1.10) $\mathrm{P}=$ 0.001
Statistically significant difference in acceptance with better acceptance in Group B compared to Group A (95\% ver- sus $40 \%, P=0.001$ ) 
Table 2. Dosage study outcomes (Continued)

Group B: 5.2

Adverse effects not reported

(1.15), 12 males

and 8 females,

$17.4(4.33)$

\section{Midazolam (oral)}

\begin{tabular}{|c|c|c|c|c|c|}
\hline Aydintug 2004 & $\begin{array}{l}\mathrm{n}=50 \\
\text { Mean age (un- } \\
\text { clear, possibly } \\
\text { SD) in years; } \\
\text { mean weight } \\
\text { (unclear, pos- } \\
\text { sibly SD) in kg; } \\
\text { gender: } \\
\text { Group } 1 \text { ( } \mathrm{n}=25) \text {, } \\
\text { 5.36 (1.7), 19.068 } \\
\text { (3.43), } 18 \text { males } \\
\text { and } 7 \text { females } \\
\text { Group } 2 \text { ( } \mathrm{n}= \\
25), 4.96(1.513), \\
17.804(3.08), 12 \\
\text { males and } 13 \mathrm{fe}- \\
\text { males }\end{array}$ & $\begin{array}{l}\text { Group 1: mi- } \\
\text { dazolam (0.5 } \\
\text { mg/kg) (oral) } \\
\text { Group 2: mi- } \\
\text { dazolam (0.35 } \\
\text { mg/kg) (rec- } \\
\text { tal) }\end{array}$ & $\begin{array}{l}\text { Ramsay Seda- } \\
\text { tion Score, ac- } \\
\text { ceptance of } \\
\text { application, } \\
\text { acceptance of } \\
\text { local anaes- } \\
\text { thesia, oper- } \\
\text { ating condi- } \\
\text { tions, state of } \\
\text { amnesia } \\
\text { Analysed us- } \\
\text { ing Chi2 test }\end{array}$ & $\begin{array}{l}\text { Acceptance of application significantly } \\
\text { better in oral group ( } 72 \% \text { excellent in oral } \\
\text { group compared to } 20 \% \text { excellent in rec- } \\
\text { tal group, } P<0.05) \\
\text { No significant difference seen }(P>0.05) \\
\text { between acceptance of local anaesthesia, } \\
\text { state of amnesia or operating conditions. } \\
\text { Ramsay's Sedation Scores not reported } \\
\text { Adverse effects: no significant difference } \\
\text { ( }>0.05) \text { in adverse effects between } \\
\text { groups ( } 56 \% \text { oral, } 44 \% \text { rectal, included } \\
\text { hypoxaemia, vomiting and nausea, disin- } \\
\text { hibition) } \\
\text { Monitoring: oxygen saturation, heart rate, } \\
\text { blood pressure }\end{array}$ & $\begin{array}{l}\text { Treatment } \\
\text { completed } \\
\text { by all partici- } \\
\text { pants }\end{array}$ \\
\hline Isik 2008b & $\begin{array}{l}\text { Mean age (SD) } \\
\text { in years, gender, } \\
\text { mean weight } \\
\text { (SD) in kg: } \\
\text { Group } 1(\mathrm{n}=14) \text {, } \\
4.6(1.2), 7 \text { males } \\
\text { and } 7 \text { females, } \\
15.6(2.8) \\
\text { Group } 2(\mathrm{n}=13), \\
4.4(1.0), 8 \text { males } \\
\text { and } 5 \text { females, } \\
16.2(2.4) \\
\text { Group } 3 \text { ( } n=13), \\
4.4(0.9), 6 \text { males } \\
\text { and } 7 \text { females, } \\
16.1(2.4) \\
\text { Group } 4(n=13), \\
4.3(0.9), 5 \text { males } \\
\text { and } 8 \text { females, } \\
15.8(2.6)\end{array}$ & $\begin{array}{l}\text { Group 1: mi- } \\
\text { dazolam (0.2 } \\
\text { mg/kg) } \\
\text { Group 2: mi- } \\
\text { dazolam (0.5 } \\
\text { mg/kg) } \\
\text { Group 3: mi- } \\
\text { dazolam (0.75 } \\
\text { mg/kg) } \\
\text { Group 4: mi- } \\
\text { dazolam (1 } \\
\text { mg/kg) } \\
\text { All oral }\end{array}$ & $\begin{array}{l}\text { Ramsay Seda- } \\
\text { tion Score } \\
\text { Analysed us- } \\
\text { ing Kruskal- } \\
\text { Wallis, Mann- } \\
\text { Whitney U test }\end{array}$ & $\begin{array}{l}\text { At the } 20 \text { minute time point, mean Ram- } \\
\text { say Sedation Score was } 1.2(0.4), 1.6(0.5) \text {, } \\
2.2(0.6), 2.7(1.0) \text { in Groups } 1-4 \text { respec- } \\
\text { tively. Children in Groups } 3 \text { and } 4 \text { were } \\
\text { more sedated than children in Groups } 1 \\
\text { and } 2 \text { ( } P<0.05) \\
\text { Sedation considered inadequate in } 12 / 14 \text {, } \\
5 / 13,3 / 13 \text { and } 5 / 13 \text { in Groups } 1-4 \text { respec- } \\
\text { tively } \\
\text { Mean recovery time was } 45 \text { (0), } 45 \text { (0), } \\
47.3 \text { ( } 8.3 \text { ), and } 57.7 \text { ( } 42.8 \text { ) minutes in } \\
\text { Groups } 1-4 \text { respectively } \\
\text { Adverse effects: most of the adverse ef- } \\
\text { fects were seen in Group } 4 \text { with } 1 \text { pa- } \\
\text { tient desaturating and } 3 \text { presenting with } \\
\text { delayed recovery, no adverse effects in } \\
\text { Group } 1 \text { and "very few" in Groups } 2 \text { and } 3 \\
\text { Monitoring: pulse oximeter }\end{array}$ & - \\
\hline Somri 2012 & $\begin{array}{l}\mathrm{n}=90 \text { (30 per } \\
\text { group) } \\
\text { Age range }=3-10 \\
\text { years } \\
\text { Mean age (SD) } \\
\text { in years, weight } \\
\text { (SD) in kg: }\end{array}$ & $\begin{array}{l}\text { Group } 1: \mathrm{mi}- \\
\text { dazolam }(0.5 \\
\mathrm{mg} / \mathrm{kg}) \\
\text { Group } 2: \mathrm{mi}- \\
\text { dazolam }(0.75 \\
\mathrm{mg} / \mathrm{kg})\end{array}$ & $\begin{array}{l}\text { Wisconsin Se- } \\
\text { dation Scale } \\
\text { Houpt behav- } \\
\text { ioural rating } \\
\text { scale } \\
\text { Parent satis- } \\
\text { faction }\end{array}$ & $\begin{array}{l}\text { Sedation and behaviour co-operation } \\
\text { scores were noted at baseline, } 15 \text { min- } \\
\text { utes, } 30 \text { minutes and } 45 \text { minutes. Signif- } \\
\text { icant difference with sedation scores in } \\
\text { Group } 1 \text { lower than Group } 2 \text { and Group } 3 \\
(P<0.001)\end{array}$ & $\begin{array}{l}\text { Group } 120 \% \\
(n=6), \text { Group } \\
26.7 \%(n=2) \\
\text { did not com- } \\
\text { plete treat- } \\
\text { ment }\end{array}$ \\
\hline
\end{tabular}


Table 2. Dosage study outcomes (Continued)

$\begin{array}{ll}\text { Group 1: } 5.6 \pm & \text { Group 3: mi- } \\ 1.85 \text { years, } 19.2 \pm & \begin{array}{l}\text { dazolam (1 } \\ \mathrm{mg} / \mathrm{kg})\end{array} \\ 3.68 \mathrm{~kg} & \\ \text { Group 2: } 5.6 \pm & \\ 1.67 \text { years, } 19.7 \pm \\ 3.38 \mathrm{~kg}\end{array}$
$\begin{aligned} & \text { Group 3: } 6.2 \pm \\ & 2.00 \text { years, } 20.3 \pm \\ & 3.65 \mathrm{~kg}\end{aligned}$

No significant difference $(P<0.001)$ in sedation score of Group 2 and Group 3 except at baseline

Behavioural co-operation score was significantly lower $(P<0.001)$ in Group 1 compared to Group 2 and Group 3. Significant difference $(P<0.001)$ in behaviour scores of Group 2 and Group 3 with Group 2 having lower scores at baseline and 45 minutes

Significant difference $(P=0.025)$ in completion scores between Group 1 and Group 3

No significant difference $(P=0.43)$ in duration between the groups

Significant difference in discharge time between the groups. Group 1 had shorter mean inpatient stay ( 85 minutes \pm 18.5 , $\mathrm{P}<0.001)$ compared to Group 2 (103.7 \pm 13.3 minutes $)$ and Group $3(137 \pm 14.7$ minutes)

Significant difference in parent satisfaction $(P<0.001)$ where Group 1 is lower than Group 2 and Group 3. No significant difference $(P=0.147)$ between Group 2 and Group 3

Adverse effects: respiratory events Group 2 (3/30), Group $3(10 / 30)$

Nausea and drowsiness Group 1 (3/30), Group 2 (7/30), Group 3 (12/30)

ANOVA = analysis of variance; $\mathrm{n}=$ number $\mathrm{SD}=$ standard deviation .

Table 3. Drug comparison study outcomes

\begin{tabular}{|c|c|c|c|c|c|}
\hline Study ID & Sample & Intervention & Outcomes & Outcome results & $\begin{array}{l}\text { Treatment } \\
\text { completed }\end{array}$ \\
\hline
\end{tabular}

\section{Chloral hydrate/hydroxyzine versus}

\begin{tabular}{|c|c|c|}
\hline $\begin{array}{l}\text { Avalos-Arenas } \\
1998\end{array}$ & $\begin{array}{l}\mathrm{n}=40 \\
\text { Mean age (SD) } \\
\text { in months and } \\
\text { gender: } \\
\text { Group } 1(\mathrm{n}= \\
20), 27.7(2.9) \text {, } \\
13 \text { males and } 7 \\
\text { females } \\
\text { Group } 2 \text { ( } \mathrm{n}= \\
20), 29.2(3.6), \\
14 \text { males and } 6 \\
\text { females }\end{array}$ & $\begin{array}{l}\text { Group 1: chloral } \\
\text { hydrate ( } 70 \mathrm{mg} / \\
\text { kg) } \\
\text { Group 2: chlo- } \\
\text { ral hydrate ( } 70 \\
\mathrm{mg} / \mathrm{kg})+ \text { hydrox- } \\
\text { yzine ( } 2 \mathrm{mg} / \mathrm{kg}) \\
\text { All oral }\end{array}$ \\
\hline
\end{tabular}

Houpt.
Analysed us-
ing Kruskal-
Wallis and
Mann-Whitney
U tests

No significant difference $(P>0.05)$ for overall behaviour evaluation (mean values reported at 7 different time intervals e.g. at injection mean behaviour Group $1=4.9($ SD 1.1), Group 2 = $5.0($ SD 0.68)

Crying and movement evaluations significantly better $(P<0.05)$ at $45-60$ minutes after application of rubber dam for Group 1

Sleep mentioned
All participants completed treatment 
Table 3. Drug comparison study outcomes (Continued)

Adverse effects: Group 1 15\%-30\% children has oxygen saturation $<90 \%$ but in Group 2 range was $10 \%-45 \%$

Monitoring: precordial stethoscope, pulse oximeter and sphygmomanometer

\begin{tabular}{lll}
\hline Meyer 1990 & $\mathrm{n}=40$ & Group 1: chloral \\
Mean age & hydrate \\
(age range) in & $(40 \mathrm{mg} / \mathrm{kg})+$ hy- \\
months: & droxyzine $(25$ \\
Group 1 $(\mathrm{n}=$ & $\mathrm{mg})$ \\
$20), 44(21$ to & Group 2: triazo- \\
$74)$ & lam $(0.02 \mathrm{mg} / \mathrm{kg})$ \\
Group 2 $(\mathrm{n}=$ & All oral \\
$20), 42(23$ to & \\
$64)$ &
\end{tabular}

Houpt. Analysed using ANOVA and $\mathrm{Chi}^{2}$ test

No significant differences between groups (mean overall behaviour Group 1 and Group 2 the same with a value of 4.3 (SE 0.4354)

Sleeping mentioned

Adverse effects: vomiting (1 child in Group 1)

Monitoring: pulse oximeter and precordial stethoscope

\begin{tabular}{llll}
\hline Moody 1986 & $\mathrm{n}=30$ & Group 1: chloral & Modified Bark- \\
& Mean age in & hydrate $(50 \mathrm{mg} /$ & er \\
months: & $\mathrm{kg})($ oral $)$ & Overall quali- \\
Group $1(\mathrm{n}=$ & Group 2: chloral & ty sedation \\
10), 39.6 & hydrate $(50 \mathrm{mg} /$ & \\
Group 2 $(\mathrm{n}=$ & $\mathrm{kg})($ rectal $)$ & Behaviour- \\
10), 42 & Group 3: chlo- & al data not \\
Group 3 $(\mathrm{n}=$ & ral hydrate $(30$ & statistically \\
10), 38.4 & mg/kg) + hydrox- & analysed \\
& yzine $(25 \mathrm{mg})$ & \\
& (oral) &
\end{tabular}

Good or excellent sedation achieved in $4 / 10,7 / 10$ and $7 / 10$ of children in oral chloral hydrate, rectal chloral hydrate and oral chloral hydrate/hydroxyzine groups respectively

Adverse effects: not mentioned

Monitoring: precordial stethoscope and pulse oximeter

All received

nitrous ox-

ide inhalation

30\%-50\%

\begin{tabular}{|c|c|c|c|}
\hline Park 2006 & $\begin{array}{l}\mathrm{n}=31 \\
\text { Mean age in } \\
\text { months (SD), } \\
\text { gender, mean } \\
\text { weight in kg } \\
\text { (SD): } \\
\text { CH Group } 44.5 \\
(14.1), 6 \text { males } \\
\text { and } 9 \text { females, } \\
15.6 \text { (2.7) } \\
\text { CH-M Group } \\
34.3 \text { (9.3), } 11 \\
\text { males and } 5 \\
\text { females, } 15.1 \\
(2.6)\end{array}$ & $\begin{array}{l}\text { CH Group: chlo- } \\
\text { ral hydrate (60 } \\
\mathrm{mg} / \mathrm{kg})+ \text { hydrox- } \\
\text { yzine (1 mg/kg) } \\
\text { (both oral) } \\
\text { CH-M Group: } \\
\text { chloral hydrate } \\
\text { ( } 60 \mathrm{mg} / \mathrm{kg} \text { oral) } \\
+ \text { hydroxyzine } \\
(1 \mathrm{mg} / \mathrm{kg} \text { oral) + } \\
\text { midazolam }(0.1 \\
\text { mg/kg submu- } \\
\text { cosal) } \\
\text { All received ni- } \\
\text { trous oxide in- } \\
\text { halation } 50 \%\end{array}$ & $\begin{array}{l}\text { Houpt } \\
\text { Requirement } \\
\text { for restraint }\end{array}$ \\
\hline
\end{tabular}

Subjects in the $\mathrm{CH}-\mathrm{M}$ Group showed better overall behaviour as measured by Houpt. Mean score 0.47 (SD 0.5) in $\mathrm{CH}$ Group versus 0.81 (0.39) in CH-M Group, $\mathrm{P}=0.004$

Less restraint was required in the $\mathrm{CH}-\mathrm{M}$ Group $(P<0.05)$

Adverse effects: not reported

Monitoring: pulse oximeter

Modified
Houpt
Analysed us-
ing Wilcoxon

Subjects in chloral hydrate/hydroxyzine

Dental treatgroup were in a significantly deeper ment abortsleep $(P<0.05)$. Data presented graphically. Sleeping mentioned ed in 1 participant from chloral hy- 
Table 3. Drug comparison study outcomes (Continued)

Group $1(\mathrm{n}=$

20), 48 ( 32 to

73), 11 males

and 9 females

Group 2 ( $\mathrm{n}=$

20), 42 ( 27 to

70), 10 males

and 10 females
Group 2: midazolam $(0.5$ $\mathrm{mg} / \mathrm{kg})+$ acetaminophen (10

$\mathrm{mg} / \mathrm{kg}$ )

All oral matched pairs test and $\mathrm{Chi}^{2}$ test
Adverse effects: not reported

Monitoring: pulse oximeter, precordial stethoscope and capnograph drate/hydroxyzine group

\begin{tabular}{|c|c|c|c|c|c|}
\hline $\begin{array}{l}\text { Torres-Perez } \\
2007\end{array}$ & $\begin{array}{l}\mathrm{n}=54 \\
\text { Mean age (age } \\
\text { range) in years; } \\
\text { mean weight } \\
\text { (range) in kg; } \\
\text { gender: } \\
\text { Group 1: } 3.9 \\
\text { (4-6), } 11 \text { males, } \\
7 \text { females, } 18.1 \\
(0.9-22) \\
\text { Group 2: } 2.83 \\
(1-8), 11 \text { males, } \\
7 \text { females, } 15 \\
\text { (10.4-22.5) } \\
\text { Group 3: } 2.94 \\
(1-10), 10 \\
\text { males, } 8 \text { fe- } \\
\text { males, } \\
\text { 16.33 (10.4-20) }\end{array}$ & $\begin{array}{l}\text { Group 1: hydrox- } \\
\text { yzine ( } 2 \mathrm{mg} / \mathrm{kg} \\
2 \text { hours before, } \\
1 \mathrm{mg} / \mathrm{kg} 20 \text { min- } \\
\text { utes before) } \\
\text { Group 2: midazo- } \\
\text { lam (0.5 mg/kg) } \\
+ \text { hydroxyzine } \\
\text { (1.5 mg/kg) } \\
\text { Group 3: chlo- } \\
\text { ral hydrate ( } 50 \\
\mathrm{mg} / \mathrm{kg})+\mathrm{hydrox}- \\
\text { yzine ( } 1.5 \mathrm{mg} / \mathrm{kg}) \\
\text { All oral }\end{array}$ & $\begin{array}{l}\text { Ohio State Be- } \\
\text { havioral Rat- } \\
\text { ing Scale } \\
\text { Analysed us- } \\
\text { ing Wilcox- } \\
\text { on matched } \\
\text { pairs test and } \\
\text { Kruskal Wallis }\end{array}$ & $\begin{array}{l}\text { "Significantly quieter" (mean cardiac } \\
\text { rate 152, } 146 \text { and } 137 \text { in Group 1, Group } \\
2 \text { and Group } 3 \text { respectively (no P value } \\
\text { given). Data presented graphically sug- } \\
\text { gesting less movement in Group } 3 \\
\text { Adverse effects: in Group } 31 / 18 \text { experi- } \\
\text { enced oxygen saturation < } 90 \% \\
\text { Monitoring: oxygen saturation and car- } \\
\text { diac rate }\end{array}$ & - \\
\hline \multicolumn{6}{|c|}{ Chloral hydrate/promethazine versus } \\
\hline Sams 1993a & $\begin{array}{l}\mathrm{n}=24 \\
\text { Mean age (SD) } \\
\text { in months: } \\
\text { Group } 1(\mathrm{n}= \\
\text { 13), } 31.0(8.6) \\
\text { Group } 2(\mathrm{n}= \\
11), 35.8(10.6)\end{array}$ & $\begin{array}{l}\text { Group } 1: \text { chloral } \\
\text { hydrate }(50 \mathrm{mg} / \\
\mathrm{kg})+ \text { promet- } \\
\text { hazine }(1 \mathrm{mg} / \mathrm{kg}) \\
\text { Group } 2: \mathrm{meperi}- \\
\text { dine }(1 \mathrm{mg} / \mathrm{kg})+ \\
\text { promethazine (1 } \\
\mathrm{mg} / \mathrm{kg}) \\
\text { All oral }\end{array}$ & $\begin{array}{l}\text { Modified } \\
\text { Houpt } \\
\text { Analysed us- } \\
\text { ing Hotelings } \\
\text { T test and 2- } \\
\text { sample t-test }\end{array}$ & $\begin{array}{l}\text { Chloral hydrate/promethazine group } \\
\text { significantly "better" }(\mathrm{P}<0.05) \text { for over- } \\
\text { all evaluation at } 4 \text { of the } 10 \text { measured } \\
\text { time intervals (e.g. mean overall behav- } \\
\text { iour } 15 \text { minutes post-injection Group } 1 \\
=5.2 \text { (SD 1.1), Group } 2=4.4 \text { (SD } 1.3), P< \\
0.05) \\
\text { Adverse effects: not reported } \\
\text { Significantly more sleep in Group } 1 \text { than } \\
\text { Group } 2\end{array}$ & $\begin{array}{l}\text { All partici- } \\
\text { pants com- } \\
\text { pleted treat- } \\
\text { ment and } \\
\text { mean treat- } \\
\text { ment duration } \\
\text { was } 50.8 \text { (SD } \\
13.3) \text { and } 50.9 \\
\text { (SD } 17.6 \text { ) in } \\
\text { Groups } 1 \text { and } \\
2 \text { respectively }\end{array}$ \\
\hline
\end{tabular}

\section{Dexmedetomidine versus}

\begin{tabular}{|c|c|c|c|c|c|}
\hline Malhotra 2016 & $\begin{array}{l}\mathrm{n}=36 \\
\begin{array}{l}\text { Age range }=3-9 \\
\text { years }\end{array} \\
\text { Mean age }(\mathrm{SD}) \\
\text { in years: } 4.60 \pm \\
1.99\end{array}$ & $\begin{array}{l}\text { Group 1: in- } \\
\text { tranasal normal } \\
\text { saline, oral mida- } \\
\text { zolam }(0.5 \mathrm{mg} / \\
\mathrm{kg})+ \text { oral keta- } \\
\text { mine }(5 \mathrm{mg} / \mathrm{kg}) \\
\text { in } 30 \mathrm{ml} \text { of man- } \\
\text { go juice } \\
\text { Group 2: in- } \\
\text { tranasal }\end{array}$ & $\begin{array}{l}\text { Modified Ob- } \\
\text { server As- } \\
\text { sessment } \\
\text { of Alertness } \\
\text { and Sedation } \\
\text { (MOAAS) } \\
\text { Houpt scale }\end{array}$ & $\begin{array}{l}\text { Significant difference }(P=0.007) \text { in be- } \\
\text { haviour during treatment compared to } \\
\text { baseline in Group } 1 \text { and Group } 2 \\
\text { Significant difference in the level of se- } \\
\text { dation in Group } 1 \text { and Group } 2 \text { when } \\
\text { a comparison is made at specific time } \\
\text { stages (treatment-baseline and, end } \\
\text { of treatment-baseline) e.g. for Group } 1 \\
\text { treatment-baseline comparison shows }\end{array}$ & - \\
\hline
\end{tabular}


Table 3. Drug comparison study outcomes (Continued)

Mean weight dexmedetomi-

(SD): $15.62 \pm \quad$ dine $(1 \mu / \mathrm{kg})$,

$4.21 \quad 30 \mathrm{ml}$ of mango

juice

Group 3: intranasal normal saline, $30 \mathrm{ml}$ of mango juice

significant difference $(P=0.002)$ in the level of sedation

No significant difference between Group 1 and Group 2 in sedative efficacy or anxiolysis potential

Adverse effects: not reported

Monitoring: blood pressure, heart rate, oxygen saturation

\begin{tabular}{|c|c|c|c|c|}
\hline Surendar 2014 & $\begin{array}{l}n=84 \\
\text { Age range in } \\
\text { years, mean } \\
\text { age }(S D) \text { in } \\
\text { years: } \\
\text { Group } 1(n=21) \\
7.34(2.34) \\
\text { Group } 2(n=21) \\
6.71(2.31) \\
\text { Group } 3(n=21) \\
7.76(2.26) \\
\text { Group } 4(n=21) \\
7.24(2.36)\end{array}$ & $\begin{array}{l}\text { Group 1: } \\
\text { dexmedetomi- } \\
\text { dine }(1 \mu \mathrm{g} / \mathrm{kg}) \\
\text { Group 2: } \\
\text { dexmedetomi- } \\
\text { dine }(1.5 \mu \mathrm{g} / \mathrm{kg}) \\
\text { Group } 3: \mathrm{mida}- \\
\text { zolam (0.2 mg/ } \\
\text { kg) } \\
\text { Group } 4: \mathrm{keta}- \\
\text { mine }(5 \mathrm{mg} / \mathrm{kg}) \\
\text { All intranasal }\end{array}$ & $\begin{array}{l}\text { Modified } \\
\text { AAPD Seda- } \\
\text { tion Record } \\
\text { Face, Legs, Ac- } \\
\text { tivity, Cry and } \\
\text { Consolability } \\
\text { (FLACC) scale }\end{array}$ & $\begin{array}{l}\text { No significant difference }(P=0.378) \text { in } \\
\text { overall behaviour was observed } \\
\text { No significant difference }(P=0.242 \\
\text { and } P=0.120) \text { in overall success rate of } \\
\text { treatment and distribution of sedation } \\
\text { levels between the groups } \\
\text { Significant difference ( } P>0.05) \text { in intra } \\
\text { and postoperative analgesic effects re- } \\
\text { ported with Group } 1 \text {, Group } 2 \text { and Group } \\
4 \text { significantly better than Group } 3 \text { e.g. } \\
\text { intraoperative analgesia score Group } \\
3=5.62 \text { (SD } 1.12 \text { ) compared to Group } 1 \\
=3.81 \text { ( } 0.81) \text {, Group } 2=3.67 \text { ( } 0.91 \text { ) and } \\
\text { Group } 4=3.52 \text { (0.68) } \\
\text { Significant difference ( } P>0.05) \text { in on- } \\
\text { set time, recovery time, pulse rate and } \\
\text { systolic blood pressure of Group } 1 \text { and } \\
\text { Group } 2 \text { compared to Group } 3 \text { and } \\
\text { Group } 4 \text { was observed } \\
\text { Adverse effects: not reported } \\
\text { Monitoring: oxygen saturation, respira- } \\
\text { tory rate, blood pressure and respiratory } \\
\text { rate }\end{array}$ \\
\hline
\end{tabular}

\section{Ketamine versus}

\begin{tabular}{|c|c|c|c|c|}
\hline Abrams 1993 & $\begin{array}{l}\mathrm{n}=30 \text { ( } 10 \text { per } \\
\text { group with } \\
\text { sufentanil di- } \\
\text { vided into } 2 \\
\text { subgroups of } 5 \\
\text { each) } \\
\text { Age range = } 17 \\
\text { to } 62 \text { months }\end{array}$ & $\begin{array}{l}\text { Group 1: keta- } \\
\text { mine ( } 3 \mathrm{mg} / \mathrm{kg}) \\
\text { Group } 2: \mathrm{mida}- \\
\text { zolam }(0.4 \mathrm{mg} / \\
\mathrm{kg}) \\
\text { Group } 3 \text { : sufen- } \\
\text { tanil ( } 1 \mu \mathrm{g}) \\
\text { Group } 4 \text { : sufen- } \\
\text { tanil (1.5 } \mu \mathrm{g}) \\
\text { All intranasal }\end{array}$ & $\begin{array}{l}\text { Sedation scor- } \\
\text { ing criteria } \\
\text { No statistical } \\
\text { tests used }\end{array}$ & $\begin{array}{l}\text { Groups } 1 \text { to } 3 \text { had mean sedation score } \\
\text { of } 4 \text { (acceptable sedation), Group } 4 \text { had } \\
\text { mean sedation score of } 7 \text { (heavy seda- } \\
\text { tion) } \\
\text { Mean recovery times ( } \pm \text { SD) were } 7( \pm 7 \text { ), } \\
3( \pm 2), 7 \text { ( } \pm 13 \text { ), and } 58( \pm 40) \text { minutes for } \\
\text { Groups } 1-4 \text { respectively } \\
\text { Sleeping mentioned } \\
\text { Adverse effects: drowsiness (Group } 1 \text { ), } \\
\text { mild obtundation and deep sedation } \\
\text { (Group } 3 \text { ), desaturations in } 4 / 5 \text { children } \\
\text { on high dose sufentanil } \\
\text { Monitoring: pulse oximeter, automatic } \\
\text { blood pressure and if necessary capno- } \\
\text { graph }\end{array}$ \\
\hline
\end{tabular}


Table 3. Drug comparison study outcomes (Continued)

\begin{tabular}{|c|c|c|c|c|c|}
\hline Rai 2007 & $\begin{array}{l}\mathrm{n}=30 \text { (10 per } \\
\text { group) } \\
\text { Age range 3-6 } \\
\text { years }\end{array}$ & $\begin{array}{l}\text { Group 1: midazo- } \\
\text { lam (0.1 mg/kg) } \\
\text { (bolus) }+0.004 \\
\mathrm{mg} / \mathrm{kg} / \mathrm{min} \text { (infu- } \\
\text { sion) } \\
\text { Group 2: propo- } \\
\text { fol ( } 1 \mathrm{mg} / \mathrm{kg} \text { ) (bo- } \\
\text { lus) }+0.06 \mathrm{mg} / \\
\mathrm{kg} / \mathrm{min} \text { (infusion) } \\
\text { Group } 3 \text { : keta- } \\
\mathrm{mine}(0.5 \mathrm{mg} / \\
\mathrm{kg} \text { ) (bolus) } 0.01 \\
\mathrm{mg} / \mathrm{kg} / \mathrm{min} \text { (infu- } \\
\text { sion) } \\
\text { All intravenous } \\
\text { All children had } \\
\text { premedication } \\
1 \text { hour before of } \\
0.5 \mathrm{mg} / \mathrm{kg} \text { mi- } \\
\text { dazolam and at- } \\
\text { ropine ( } 0.6 \text { mg) }\end{array}$ & $\begin{array}{l}\text { Houpt } \\
\text { Analysed } \\
\text { Kruskal Wallis }\end{array}$ & $\begin{array}{l}\text { The maximum level of co-operation was } \\
\text { seen with ketamine then propofol and } \\
\text { then midazolam }(\mathrm{P}<0.001) \\
\text { At treatment end mean scores were } 5.8 \\
\pm 0.42,3.5 \pm 1.08 \text { and } 3.2 \pm 0.42 \text { in keta- } \\
\text { mine, propofol and midazolam groups } \\
\text { respectively } \\
\text { Propofol showed the fastest postoper- } \\
\text { ative recovery score followed by keta- } \\
\text { mine and the midazolam. Sleeping was } \\
\text { reported } \\
\text { Adverse effects: pain on injection with } \\
\text { propofol and intermittent cough } \\
\text { Monitoring: vital signs }\end{array}$ & - \\
\hline $\begin{array}{l}\text { Roelofse } \\
\text { 1996a }\end{array}$ & $\begin{array}{l}n=100 \\
\text { Mean age (SD) } \\
\text { in years, gen- } \\
\text { der: } \\
\text { Group } 1(\mathrm{n}= \\
50), 4.3(1), 24 \\
\text { males and } 26 \\
\text { females } \\
\text { Group } 2(\mathrm{n}= \\
50), 4.3(1.1), 22 \\
\text { males and } 28 \\
\text { females }\end{array}$ & $\begin{array}{l}\text { Group 1: keta- } \\
\text { mine }(5 \mathrm{mg} / \mathrm{kg})+ \\
\text { midazolam }(0.35 \\
\mathrm{mg} / \mathrm{kg}) \\
\text { Group } 2: \mathrm{mida}- \\
\text { zolam }(1 \mathrm{mg} / \mathrm{kg}) \\
\text { All rectal }\end{array}$ & $\begin{array}{l}\text { Ramsay Seda- } \\
\text { tion Score } \\
\text { Movement } \\
\text { Crying } \\
\text { Overall seda- } \\
\text { tion and be- } \\
\text { haviour } \\
\text { Analysed us- } \\
\text { ing McNew- } \\
\text { man's test } \\
\text { (sic), Chi² and } \\
\text { Fisher's Exact } \\
\text { tests }\end{array}$ & $\begin{array}{l}\text { Significant differences in level of seda- } \\
\text { tion with } 71 \% \text { subjects in Group } 2 \text { "ori- } \\
\text { entated and calm" compared to } 14 \% \text { in } \\
\text { Group } 130 \text { minutes after administration } \\
\text { Significantly less movement and crying } \\
(P<0.05) \text { in Group } 1(58 \% \text { no movement } \\
\text { at all compared to } 14 \% \text { in Group } 2) \\
\text { Sleep mentioned } \\
\text { Adverse effects: hallucination (Groups } 1 \\
(14 \%) \text { and } 2 \text { ( } 42 \%) \text { ), nausea (Group } 1) \\
\text { Monitoring: pulse oximeter }\end{array}$ & $\begin{array}{l}\text { Dental treat- } \\
\text { ment abort- } \\
\text { ed in } 1 \text { partic- } \\
\text { ipant (keta- } \\
\text { mine/midazo- } \\
\text { lam group) }\end{array}$ \\
\hline $\begin{array}{l}\text { Roelofse } \\
\text { 1996b }\end{array}$ & $\begin{array}{l}\mathrm{n}=60 \\
\text { Mean age (SD) } \\
\text { in years, gen- } \\
\text { der: } \\
\text { Group } 1(\mathrm{n}= \\
30), 4.8(1.3), 14 \\
\text { males and } 16 \\
\text { females } \\
\text { Group } 2(\mathrm{n}= \\
30), 4.9(1.3), 16 \\
\text { males and } 14 \\
\text { females }\end{array}$ & $\begin{array}{l}\text { Group 1: } \\
0.5 \mathrm{ml} / \mathrm{kg} \text { of } \\
\text { trimeprazine } \\
6 \mathrm{mg} / \mathrm{ml}+ \\
\text { physeptone } \\
\text { (methadone) } \\
\text { (0.4 } \mathrm{mg} / \mathrm{ml})+ \\
\text { droperidol (0.1 } \\
\mathrm{mg} / \mathrm{kg} \text { ) } \\
\text { Group } 2: \text { keta- } \\
\text { mine ( } 12.5 \mathrm{mg} / \\
\mathrm{kg} \text { ) } \\
\text { All oral }\end{array}$ & $\begin{array}{l}\text { Anxiety } \\
\text { Level of seda- } \\
\text { tion } \\
\text { Movement } \\
\text { Crying } \\
\text { Overall be- } \\
\text { haviour } \\
\text { Analysed us- } \\
\text { ing McNemar } \\
\text { test, Chi² and } \\
\text { Fisher's Exact } \\
\text { tests }\end{array}$ & $\begin{array}{l}\text { Sedation was significantly "better" (very } \\
\text { good/excellent } 80 \% \text { and } 93 \% \text { of Group } 1 \\
\text { and Group } 2 \text { respectively) } \\
\text { Overall evaluation good/very good in } \\
67 \% \text { and } 90 \% \text { of Group } 1 \text { and Group } 2 \text { re- } \\
\text { spectively } \\
\text { Sleeping mentioned } \\
\text { Adverse effects: hallucination ( } 9 \text { and 5), } \\
\text { restless/irritation } 4 \text { and } 1 \text {, in Group } 1 \\
\text { and Group } 2 \\
\text { Ketamine also } 2 \text { vomiting/nausea, } 4 \text { vi- } \\
\text { sual disturbances and } 4 \text { excess saliva- } \\
\text { tion } \\
\text { Monitoring: pulse oximeter }\end{array}$ & $\begin{array}{l}\text { All partici- } \\
\text { pants com- } \\
\text { pleted treat- } \\
\text { ment }\end{array}$ \\
\hline
\end{tabular}


Table 3. Drug comparison study outcomes (Continued)

\begin{tabular}{|c|c|c|c|}
\hline Roelofse 1998 & $\begin{array}{l}n=100 \\
\text { Mean age (SD) } \\
\text { in years, gen- } \\
\text { der: } \\
\text { Group } 1(\mathrm{n}= \\
50), 4.1(1.3), 27 \\
\text { males and } 23 \\
\text { females } \\
\text { Group } 2 \text { ( } \mathrm{n}= \\
50), 4(1.2), 29 \\
\text { males and } 21 \\
\text { females }\end{array}$ & $\begin{array}{l}\text { Group 1: keta- } \\
\text { mine (5 mg/kg) + } \\
\text { midazolam }(0.35 \\
\text { mg/kg) } \\
\text { Group 2: } \\
\text { trimeprazine } \\
\text { (3 mg/kg) + } \\
\text { methadone }(0.2 \\
\text { mg/kg) } \\
\text { All oral }\end{array}$ & $\begin{array}{l}\text { Modified } \\
\text { Houpt, Ram- } \\
\text { say Sedation } \\
\text { Score } \\
\text { Analysed us- } \\
\text { ing McNe- } \\
\text { mar's test, } \\
\text { Chi² and Fish- } \\
\text { er's Exact } \\
\text { tests }\end{array}$ \\
\hline
\end{tabular}

Significant differences $(P<0.05)$ in level of sedation immediately before treatment with $46 \%$ participants in Group 1 "oriented and calm" compared to $84 \%$ in Group 2

Overall surgeons rated $94 \%$ versus $78 \%$ of sedations as good/very good in Group 1 versus Group 2

Sedation rated as poor in significantly more children in Group 2 (24\%) than Group 1 (6\%)

Sleeping mentioned

Adverse effects: vomiting $(n=2)$ and hallucination $(n=10)$ in Group 1

Monitoring: pulse oximeter

\begin{tabular}{|c|c|c|c|c|c|}
\hline Singh 2014 & $\begin{array}{l}\mathrm{n}=112 \\
\text { Age range }= \\
1-10 \text { years } \\
\text { Mean age (SD) } \\
\text { in years, gender } \\
\text { and weight (SD) } \\
\text { in kg: } \\
\text { Group } 1 \text { ( } \mathrm{n}= \\
28), 6.54(1.79), \\
14 \text { males and } \\
14 \text { females, } \\
18.89 \text { ( } 4.33) \\
\text { Group } 2(\mathrm{n}= \\
28), 6.93(2.05), \\
13 \text { males and } \\
15 \text { females, } \\
17.04(5.33) \\
\text { Group } 3(\mathrm{n}= \\
28), 7.21(1.98), \\
11 \text { males and } \\
17 \text { females, } \\
16.93(4.22) \\
\text { Group } 4(\mathrm{n}= \\
28), 6.82(2.22), \\
14 \text { males and } \\
14 \text { females, } \\
16.61(4.92)\end{array}$ & $\begin{array}{l}\text { Group 1: keta- } \\
\text { mine }\left(8 \mathrm{mg} / \mathrm{kg}^{-1}\right) \\
\text { Group 2: } \\
\text { dexmedetomi- } \\
\text { dine }\left(3 \mu \mathrm{g} / \mathrm{kg}^{-1}\right) \\
\text { Group 3: } \\
\text { dexmedetomi- } \\
\text { dine }\left(4 \mu \mathrm{g} / \mathrm{kg}^{-1}\right) \\
\text { Group } 4: \\
\text { dexmedetomi- } \\
\text { dine }\left(5 \mu \mathrm{g} / \mathrm{kg}^{-1}\right) \\
\text { All oral }\end{array}$ & $\begin{array}{l}\text { Onset time, } \\
\text { recovery time } \\
\text { Sedation rat- } \\
\text { ing scale mod- } \\
\text { ified from } \\
\text { AAPD guide- } \\
\text { lines } \\
\text { Face, Legs, Ac- } \\
\text { tivity, Cry and } \\
\text { Consolabili- } \\
\text { ty Pain Scale } \\
\text { (FLACC) } \\
\text { Anterograde } \\
\text { amnesia } \\
\text { Behaviour } \\
\text { score }\end{array}$ & $\begin{array}{l}\text { Group } 4 \text { had highest "adequate" depth } \\
\text { of sedation and "satisfactory" comple- } \\
\text { tion of treatment ( } 82.1 \%, 85.7 \% \text { respec- } \\
\text { tively), but was not significantly differ- } \\
\text { ent to Group } 1 \text {, Group } 2 \text { and Group } 3 \\
\text { Significant difference ( } P<0.001 \text { ) in low- } \\
\text { ering of pulse rate and systolic blood } \\
\text { pressure in Group } 2, \text { Group } 3 \text { and Group } \\
4 \text { compared to Group } 1 \\
\text { Significant difference ( } P<0.001 \text { ) in on- } \\
\text { set time, recovery time (except Group } 1 \\
\text { and Group } 4 \text { ), intra and postoperative } \\
\text { pain scores when comparing the groups } \\
\text { e.g. postoperative pain score in Group } \\
1=1.54 \text { ( } 0.63 \text { ) and Group } 4=1.79 \text { ( } 0.74 \text { ) } \\
\text { were lower compared to Group } 2=2.43 \\
\text { (0.88) and Group } 3=2.11(1.19 \text { ) } \\
\text { Adverse effects: in office vomiting } \\
\text { (Group } 1 \mathrm{n}=5 \text {, Group } 4 \mathrm{n}=1 \text { ), emer- } \\
\text { gency reaction (Group } 1 \mathrm{n}=2 \text { ) } \\
\text { Monitoring: oxygen saturation, respira- } \\
\text { tory rate, blood pressure and respiratory } \\
\text { rate }\end{array}$ & - \\
\hline $\begin{array}{l}\text { Alfon- } \\
\text { zo-Echeverri } \\
1993\end{array}$ & $\begin{array}{l}\mathrm{n}=40 \\
\text { Mean age (SD) } \\
\text { in months: } \\
\text { Group } 1(\mathrm{n}= \\
\text { 20) } 40.4(10.2) \\
\text { Group } 2(\mathrm{n}= \\
\text { 20) } 37.5(10.6)\end{array}$ & $\begin{array}{l}\text { Group 1: keta- } \\
\text { mine }(6 \mathrm{mg} / \mathrm{kg}) \\
\text { Group } 2: \mathrm{meperi}- \\
\text { dine }(2.0 \mathrm{mg} / \mathrm{kg}) \\
+ \text { promethazine } \\
\text { (0.5 } \mathrm{mg} / \mathrm{kg}) \\
\text { All oral }\end{array}$ & $\begin{array}{l}\text { Modified } \\
\text { Houpt } \\
\text { Analysed us- } \\
\text { ing Chi test }\end{array}$ & $\begin{array}{l}\text { "Good sedation" in } 65 \% \text { of ketamine } \\
\text { group and } 45 \% \text { of meperidine/promet- } \\
\text { hazine } \\
\text { Overall no statistically significant dif- } \\
\text { ference in distribution of sedation out- } \\
\text { comes between groups ( } P=0.07 \text { ) }\end{array}$ & $\begin{array}{l}\text { Dental treat- } \\
\text { ment abort- } \\
\text { ed in } 4 \text { chil- } \\
\text { dren receiv- } \\
\text { ing meperi- } \\
\text { dine and none }\end{array}$ \\
\hline
\end{tabular}


Table 3. Drug comparison study outcomes (Continued)

All received

nitrous oxide

$30 \%-50 \%$
Sedation onset time and recovery time both shorter for ketamine $(P<0.001$ and $\mathrm{P}=0.08$ respectively)

Adverse effects: vomiting (Groups $1(\mathrm{n}=$ 8) and $2(n=1))$

Monitoring: precordial stethoscope and pulse oximeter

\begin{tabular}{|c|c|c|c|c|c|}
\hline Bui 2002 & $\begin{array}{l}n=22 \\
\text { Mean age (SD) } \\
\text { in months: } \\
\text { Group } 1(n= \\
\text { 11) } 34(6.28) \\
\text { Group } 2(n= \\
\text { 11) } 33(6.65)\end{array}$ & $\begin{array}{l}\text { Group } 1: \text { keta- } \\
\text { mine }(10 \mathrm{mg} / \mathrm{kg}) \\
+ \text { promethazine } \\
(1.1 \mathrm{mg} / \mathrm{kg}) \\
\text { Group } 2: \mathrm{keta}- \\
\text { mine }(10 \mathrm{mg} / \mathrm{kg}) \\
\text { All oral } \\
\text { All received ni- } \\
\text { trous oxide } 50 \%\end{array}$ & $\begin{array}{l}\text { Houpt } \\
\text { Analysed us- } \\
\text { ing Mann- } \\
\text { Whitney U test }\end{array}$ & $\begin{array}{l}\text { Statistically significant difference in } \\
\text { mean Houpt score favouring ketamine } \\
\text { group (mean score } 4.27, \text { SD 0.5) (Group } 1 \\
\text { (mean score 3.12, SD 0.29)) ( } P<0.05 \text { ) } \\
\text { Adverse effects: } 3 \text { patients from Group } 2 \\
\text { vomited. Most of the patients reported } \\
\text { as being drowsy or asleep after } 25 \text { min- } \\
\text { utes }\end{array}$ & $\begin{array}{l}\text { Dental treat- } \\
\text { ment abort- } \\
\text { ed in } 1 \text { par- } \\
\text { ticipant from } \\
\text { Group } 1 \text { due } \\
\text { to violent } \\
\text { physical } \\
\text { movement } \\
\text { and crying }\end{array}$ \\
\hline
\end{tabular}

\section{Ketamine/midazolam versus}

\begin{tabular}{|c|c|c|c|c|c|}
\hline Gomes 2017 & $\begin{array}{l}\text { Mean age }(\mathrm{SD}) \\
\text { in years, gen- } \\
\text { der, mean } \\
\text { weight }(25 \% \\
\text { median to } 75 \%) \\
\text { in kg: } \\
\text { Group } 1(\mathrm{n}= \\
13), 4.7(0.6) \text {, } \\
10 \text { males, } 3 \text { fe- } \\
\text { males, } 16.5 \\
(15.7-19.6) \\
\text { Group } 2(\mathrm{n}= \\
14), 5.2(0.8) \text {, } \\
8 \text { males, } 6 \mathrm{fe}- \\
\text { males, } 19.6 \\
(16.7-23.9)\end{array}$ & $\begin{array}{l}\text { Group 1: mida- } \\
\text { zolam (0.5 mg/ } \\
\mathrm{kg} \text { ) + ketamine (3 } \\
\mathrm{mg} / \mathrm{kg} \text { ) (oral) } \\
\text { Group 2: mida- } \\
\text { zolam }(0.5 \mathrm{mg} / \\
\mathrm{kg})(\text { oral) + keta- } \\
\text { mine ( } 3 \mathrm{mg} / \mathrm{kg} \text { ) } \\
\text { (oral) + sevoflu- } \\
\text { rane (0.1\%-0.4\% } \\
\text { inhalation) }\end{array}$ & $\begin{array}{l}\text { Houpt } \\
\text { Analysed us- } \\
\text { ing Mann- } \\
\text { Whitney U test } \\
\text { Adverse } \\
\text { events } \\
\text { Analysed us- } \\
\text { ing Chi2 test }\end{array}$ & $\begin{array}{l}\text { No significant difference in overall } \\
\text { Houpt score between the } 2 \text { groups ( } P> \\
0.05 \text { data presented graphically) } \\
\text { Adverse events: more children in Group } \\
1 \text { reported adverse events at } 24 \text { hours } \\
\text { than Group } 2 \text { (Group } 1 \mathrm{n}=10 \text {, Group } 2 \mathrm{n} \\
=4 ; \mathrm{P}=0.01 \text { ) } \\
\text { Adverse events seen in all children in- } \\
\text { cluded: excessive drowsiness } 22 \%(\mathrm{n}= \\
6 \text { ), vomiting } 22 \% \text { ( } \mathrm{n}=6 \text { ) } \\
\text { No apnoea /drop in oxygen saturation } \\
\text { seen } \\
\text { Monitoring: pulse oximeter }\end{array}$ & $\begin{array}{l}\text { Treatment not } \\
\text { completed in } \\
1 \text { child from } \\
\text { Group } 1 \text { due } \\
\text { to poor co-op- } \\
\text { eration }\end{array}$ \\
\hline
\end{tabular}

\section{Midazolam (oral) versus}

\begin{tabular}{|c|c|c|c|c|c|}
\hline Baygin 2010 & 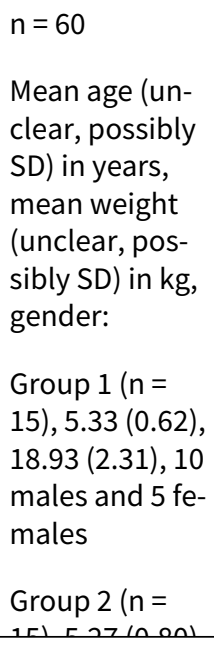 & $\begin{array}{l}\text { Group 1: hydrox- } \\
\text { yzine (1 mg/kg) } \\
\text { (oral) } \\
\text { Group 2: midazo- } \\
\text { lam (0.7 mg/kg) } \\
\text { Group 3: keta- } \\
\text { mine (3 mg/kg) + } \\
\text { midazolam (0.25 } \\
\text { mg/kg) } \\
\text { Group 4: no oral } \\
\text { premedication } \\
\text { 40\% nitrous ox- } \\
\text { ide oxygen was }\end{array}$ & $\begin{array}{l}\text { Ramsay Se- } \\
\text { dation Score, } \\
\text { Bispectral In- } \\
\text { dex System }\end{array}$ & $\begin{array}{l}\text { Ramsay Sedation Scores (RSS) were sig- } \\
\text { nificantly greater in Group } 2 \text { compared } \\
\text { to Groups } 1,3 \text { and } 4(\mathrm{P}<0.05) \\
\text { RSS satisfactory/mid-level satisfacto- } \\
\text { ry/unsatisfactory } \\
\text { was as follows: } \\
\text { Group 1: } 13.3 \% / 53.3 \% / 33.3 \% \\
\text { Group 2: } 54 \% / 20 \% / 26 \% \\
\text { Group 3: } 33.3 \% / 33.3 \% / 33.3 \% \\
\text { Group 4: } 6.7 \% / 60 \% / 33.3 \% \\
\text { P value or significance not reported }\end{array}$ & $\begin{array}{l}\text { Figure } 5 \text { used } \\
\text { to extrapo- } \\
\text { late data with } \\
\text { score } 3 \text { given } \\
\text { to satisfacto- } \\
\text { ry, } 2 \text { middle } \\
\text { level, } 1 \text { unsat- } \\
\text { isfactory } \\
\text { All partici- } \\
\text { pants com- } \\
\text { pleted treat- } \\
\text { ment }\end{array}$ \\
\hline
\end{tabular}


Table 3. Drug comparison study outcomes (Continued)

19.07 (3.62), $11 \quad$ administered to

males and $4 \mathrm{fe}$ - all participants

males

Group $3(\mathrm{n}=$

15), $5.20(0.41)$,

18.20 (2.34), 9

males and $6 \mathrm{fe}$ -

males

Group $4(\mathrm{n}=$

15), $5.53(0.99)$,

20.01 (3.99), 6

males and $9 \mathrm{fe}$ -

males

Adverse effects: nausea/vomiting ( $\mathrm{n}=$ $1 / 2 / 3 / 4)$, cough $(4 / 4 / /)$, hiccough $(/ 1 / / 5)$, enuresis $(/ 2 / /)$, bronchospasm $(/ 1 / /)$, hypersalivation $(/ / 8 /)$, otalgia $(/ / / 2)$, hallucination $(/ / 2 /)$, and epistaxis $(/ / / 1)$ in patients in groups $1,2,3$, and 4 , respectively

Monitoring: pulse oximeter

\begin{tabular}{ll}
\hline Bhatnagar & $\mathrm{n}=60$ \\
2012 & $\begin{array}{l}\text { Age range }=3-9 \\
\text { years }\end{array}$
\end{tabular}

Group 1: midazo-

Group 2: tramadol $(2 \mathrm{mg} / \mathrm{kg})$

Group 3: triclofos

(70 mg/kg)

Group 4: zolpi-

$\operatorname{dem}(0.4 \mathrm{mg} / \mathrm{kg})$

All oral lam $(0.5 \mathrm{mg} / \mathrm{kg})$
Sedation rat-
ing scale

Ease of treat-

ment completion
Significant difference $(P<0.001)$ in the

level of sedation (median scores) with Group $4>$ Group $3>$ Group 2 = Group 1

Mean score in the ease of treatment shown in the table of results reports Group $4>$ Group $3>$ Group $2>$ Group 1

No statistical difference between $(P>$ 0.05) between Group 1, Group 2, Group 3 in ease of treatment. Group 4 was found to have a statistical difference compared to the other groups $(P<0.001)$

Adverse effects: not mentioned

\begin{tabular}{|c|c|c|}
\hline Moreira 2013 & $\begin{array}{l}\mathrm{n}=44 \\
\text { Average age be- } \\
\text { low } 36 \text { months } \\
\text { Mean age (SD) } \\
\text { in months, gen- } \\
\text { der: } \\
\text { Group } 1 \text { ( } \mathrm{n}= \\
\text { 11), } 27.1(8.3), 6 \\
\text { males and } 5 \text { fe- } \\
\text { males } \\
\text { Group } 2 \text { ( } n=18, \\
\text { parents refused } \\
\text { treatment for } \\
\text { 2), } 27.7 \text { ( } 5.5), 9 \\
\text { males and } 7 \text { fe- } \\
\text { males } \\
\text { Group } 3 \text { ( } n=15 \text {, } \\
\text { parents refused } \\
\text { treatment for } \\
1 \text { ), } 27.3(6.4), 9 \\
\text { males and } 4 \text { fe- } \\
\text { males }\end{array}$ & $\begin{array}{l}\text { Group 1: mida- } \\
\text { zolam (0.5 mg/ } \\
\mathrm{kg})+ \text { ketamine (3 } \\
\mathrm{mg} / \mathrm{kg}) \\
\text { Group 2: midazo- } \\
\text { lam (1 mg/kg) } \\
\text { Group 3: no se- } \\
\text { dation } \\
\text { Group } 1 \text { and } 2 \\
\text { oral }\end{array}$ \\
\hline
\end{tabular}

Ohio State University Behavior Rating Scale (OSUBRS)

Significant difference in behaviour ( $P$ $=0.003$ ) between Group 1 and Group 2 and Group 1 and Group $3(P=0.03)$ when sedatives used

All participants completed treatment

Behaviour during various stages of treatment sessions was observed e.g. for local anaesthetic administration OSUBRS score for Group 1 was lower than Group $2(P=0.06)$ and Group $3(P=$ 0.02)

During rubber dam placement OSUBRS score for Group 1 was lower than Group $2(P=0.01)$ and Group $3(P=0.07)$. All Groups showed same behavioural pattern at the end of the treatment session $(P=0.25)$

Sleep mentioned

Adverse effects: within 24 hour postoperatively Group 1 presented with agitation and vomiting in 3 children 
Table 3. Drug comparison study outcomes (Continued)

\begin{tabular}{|c|c|c|c|c|c|}
\hline Koirala 2006 & $\begin{array}{l}\mathrm{n}=120 \text { ( } 20 \text { per } \\
\text { group) } \\
\text { Age range: } 2-9 \\
\text { years }\end{array}$ & $\begin{array}{l}\text { Group 1: midazo- } \\
\text { lam (9.5 mg/kg) } \\
\text { Group 2: keta- } \\
\text { mine (5 mg/kg) } \\
\text { Group 3: zolpi- } \\
\text { dem (0.4 mg/kg) } \\
\text { Group 4: mida- } \\
\text { zolam (0.4 mg/ } \\
\text { kg) + ketamine (3 } \\
\text { mg/kg) } \\
\text { Group 5: mida- } \\
\text { zolam (0.5 mg/ } \\
\text { kg) + tramadol (2 } \\
\text { mg/kg) } \\
\text { Group 6: zolpi- } \\
\text { dem (0.4 mg/kg) } \\
+ \text { tramadol (2 } \\
\text { mg/kg) } \\
\text { All oral }\end{array}$ & $\begin{array}{l}\text { Onset of ac- } \\
\text { tion } \\
\text { Level of seda- } \\
\text { tion } \\
\text { Ease of treat- } \\
\text { ment comple- } \\
\text { tion }\end{array}$ & $\begin{array}{l}\text { Group } 4 \text { and } 5 \text { the "best" and Groups } 3 \\
\text { and } 6 \text { the "worst" when compared on } \\
\text { level of sedation ( } P<0.001) \\
\text { Group } 4 \text { had the shortest time of onset } \\
\text { of sedation } \\
\text { (Data presented graphically) } \\
\text { No adverse effects were reported }\end{array}$ & - \\
\hline Singh 2002 & $\begin{array}{l}\mathrm{n}=90 \text { (30 per } \\
\text { group) } \\
\text { Age range: } 3-9 \\
\text { years }\end{array}$ & $\begin{array}{l}\text { Group 1: midazo- } \\
\text { lam (0.5 mg/kg) } \\
\text { Group 2: triclo- } \\
\text { fos ( } 70 \mathrm{mg} / \mathrm{kg}) \\
\text { Group 3: } \\
\text { promethazine } \\
\text { (1.2 mg/kg) } \\
\text { All oral }\end{array}$ & $\begin{array}{l}\text { Degree of se- } \\
\text { dation } \\
\text { Time of onset, } \\
\text { time of recov- } \\
\text { ery } \\
\text { Statistical } \\
\text { techniques } \\
\text { not described }\end{array}$ & $\begin{array}{l}\text { Transformed sedative scores } \\
\text { Group } 1: 3.3 \pm 0.7 \text { (best) } \\
\text { Group } 2: 3.07 \pm 0.6 \\
\text { Group } 3: 2.73 \pm 0.5 \\
\text { Both Groups } 1 \text { and } 2 \text { were statistically } \\
\text { significantly better than Group } 3 \text { (P < } \\
0.05 \text { ) } \\
\text { Time of onset and time of recovery were } \\
\text { both shortest in Group } 1 \\
\text { Adverse effects: not mentioned } \\
\text { Monitoring: blood pressure, heart and } \\
\text { respiratory rate }\end{array}$ & - \\
\hline Özen 2012 & $\begin{array}{l}\mathrm{n}=240(\mathrm{n}=60 \\
\text { per group) } \\
\text { Mean age (SD) } \\
\text { in months } 57.02 \\
(9.31)\end{array}$ & $\begin{array}{l}\text { Group } 1 \text { : mida- } \\
\text { zolam }(0.20 \mathrm{mg} / \\
\mathrm{kg}(40 \mathrm{mg} / \mathrm{ml})) \\
\text { (intranasally) + } \\
\text { inhalation se- } \\
\text { dation } 50 \%- \\
50 \% \text { nitrous ox- } \\
\text { ide/oxygen } \\
\text { Group } 2 \text { : mida- } \\
\text { zolam (0.75 mg/ } \\
\text { kg (15 mg/3 ml)) } \\
\text { (orally) + inhala- } \\
\text { tion sedation } \\
50 \%-50 \% \text { ni- } \\
\text { trous oxide/oxy- } \\
\text { gen }\end{array}$ & $\begin{array}{l}\text { Bispectral In- } \\
\text { dex System } \\
\text { (BIS) } \\
\text { Modified scale } \\
\text { to classify be- } \\
\text { haviour } \\
\text { Vancouver Re- } \\
\text { covery Scale }\end{array}$ & $\begin{array}{l}\text { Modified scale used to classify behav- } \\
\text { iour/ respond to treatment/sedation } \\
\text { was highest in Group } 1(87 \%) \text { followed } \\
\text { by Group } 2(79 \%) \text {, Group } 3(72 \%) \text { and } \\
\text { Group } 4(55 \%) \text { respectively } \\
\text { No significant difference (P = } 0.230 \text { and } \\
\text { P = } 0.399) \text { in overall success rate be- } \\
\text { tween Group } 1 \text { and Group } 2 \text {, Group } 2 \\
\text { and Group } 3 \text { respectively. Significant dif- } \\
\text { ference (P < } 0.05) \text { between Group } 1 \text { and } \\
\text { Group } 3 \text {. Significant difference Group } 4 \\
\text { compared to all other groups } \\
\text { BIS values recorded every } 5 \text { minutes, } \\
\text { Group } 2 \text { was most sedated except for } \\
\text { at } 30 \text { minutes. From } 15 \text { minutes to end }\end{array}$ & - \\
\hline
\end{tabular}


Table 3. Drug comparison study outcomes (Continued)

\author{
Group 3: mida- \\ zolam $(0.50 \mathrm{mg} /$ \\ $\mathrm{kg}(15 \mathrm{mg} / 3 \mathrm{ml}))$ \\ (orally) + inhala- \\ tion sedation \\ 50\%-50\% ni- \\ trous oxide/oxy- \\ gen
}

Group 4: inhalation sedation $50 \%-50 \%$ nitrous oxide/oxygen of treatment all groups had BIS value above 90

Recovery time in minutes was shorter for intranasal midazolam (22.3) compared to $0.50 \mathrm{mg} / \mathrm{kg}$ oral midazolam (27.5) and $0.75 \mathrm{mg} / \mathrm{kg}$ oral midazolam (29.2)

Sleep mentioned

Adverse effects:

- drug administration: vomiting in oral midazolam group (4), nose bleeding intranasal midazolam group (1), transient burning and discomfort nasal midazolam group (not reported)

- recovery period: vomiting in oral midazolam group (7), coughing in intranasal midazolam group (1), transient burning and discomfort nasal midazolam group (not reported)

- after discharge: irritability (42\%), crying (34\%), sleepiness (31\%), nausea $(5 \%)$

\begin{tabular}{|c|c|c|c|c|}
\hline Tyagi 2012 & $\begin{array}{l}\mathrm{n}=40 \\
\text { Age range = } \\
2-10 \text { years }\end{array}$ & $\begin{array}{l}\text { Group 1: mida- } \\
\text { zolam (0.5 mg/ } \\
\text { kg) (oral) } \\
\text { Group 2: di- } \\
\text { azepam (0.5 } \\
\text { mg/kg) (oral) } \\
\text { Group 3: mida- } \\
\text { zolam (0.06 mg/ } \\
\text { kg) (intravenous) } \\
\text { Group 4: place- } \\
\text { bo }\end{array}$ & $\begin{array}{l}\text { Houpt scale } \\
\text { Child behav- } \\
\text { iour question- } \\
\text { naire }\end{array}$ & $\begin{array}{l}\text { Behaviour was assessed in terms of } \\
\text { sleep, crying and movement at } 30 \text { min- } \\
\text { utes postdrug administration in Group } \\
1 \text {, Group } 2 \text { and Group } 4 \text { or } 5 \text { minutes in } \\
\text { Group } 3 \text {. At placement of blood pres- } \\
\text { sure cuff, during administration of local } \\
\text { anaesthesia or use of hand piece and } \\
\text { every } 15 \text { minutes thereafter e.g. at ad- } \\
\text { ministration of local anaesthetic agent } \\
\text { or use of hand piece significantly lower } \\
\text { (P<0.001) sleep in Group } 4 \text { compared to } \\
\text { other groups. Significantly less crying in } \\
\text { Group } 3 \text { compared to Group } 1 \text {, Group } 2 \\
\text { and Group } 4 \text { ( } P<0.001, P<0.01 \text { and } P< \\
0.05 \text { respectively) } \\
\text { Overall behaviour rating was signifi- } \\
\text { cantly better ( } P<0.001 \text { ) in Group } 3 \text { com- } \\
\text { pared to other groups } \\
\text { Positive behaviour postsedation: no sig- } \\
\text { nificant difference between Group } 1 \text { and } \\
\text { Group } 2 \text {. Significant improvement ( } P< \\
0.05) \text { in Group } 3 \text { compared to Group } 2 \\
\text { Sleeping mentioned } \\
\text { Adverse effects: not reported } \\
\text { Monitoring: oxygen saturation, respira- } \\
\text { tory rate, blood pressure and respiratory } \\
\text { rate }\end{array}$ \\
\hline
\end{tabular}


Table 3. Drug comparison study outcomes (Continued)

Midazolam (intravenous) versus

\begin{tabular}{|c|c|c|c|c|c|}
\hline Kaviani 2015 & $\begin{array}{l}\mathrm{n}=38 \\
\text { Age range = 4-9 } \\
\text { years } \\
\text { Gender, mean } \\
\text { age in years: } \\
\text { Group } 1 \text { ( } \mathrm{n}= \\
18 \text { ), } 8 \text { males } \\
\text { and } 10 \text { females, } \\
6.27 \\
\text { Group } 2 \text { ( } \mathrm{n}= \\
20 \text { ), } 12 \text { males } \\
\text { and } 8 \text { females, } \\
6.75\end{array}$ & $\begin{array}{l}\text { Group 1: midazo- } \\
\text { lam }(0.05 \mathrm{mg} / \mathrm{kg}) \\
+ \text { ketamine }(0.5 \\
\mathrm{mg} / \mathrm{kg}) \\
\text { Group } 2: \text { mida- } \\
\text { zolam }(0.05 \mathrm{mg} / \\
\mathrm{kg})+ \text { fentanyl } \\
(0.5 \mu \mathrm{gg} / \mathrm{kg}) \\
\text { All intravenous, } \\
\text { administered by } \\
\text { an anaesthesiol- } \\
\text { ogist }\end{array}$ & $\begin{array}{l}\text { Dental Seda- } \\
\text { tion Teacher } \\
\text { Groups Sys- } \\
\text { tem } \\
\text { Frankl behav- } \\
\text { iour rating } \\
\text { scale }\end{array}$ & $\begin{array}{l}\text { No significant difference }(P>0.05) \text { in in- } \\
\text { traoperative sedation score and score of } \\
\text { operative conditions at } 10^{\text {th }}, 20^{\text {th }}, 30^{\text {th }} \\
\text { and } 40^{\text {th }} \text { minute } \\
\text { Significant difference }(P<0.05) \text { in the } \\
\text { sedation score and score of operating } \\
\text { condition in Group } 1 \text { and Group } 2 \text { at } \\
10 \text { - } 20 \text { minutes, } 10 \text {-30 minutes } \\
\text { Adverse effects: not reported }\end{array}$ & - \\
\hline Eshghi 2016 & $\begin{array}{l}\mathrm{n}=32 \\
\text { Age range = 3-7 } \\
\text { years } \\
\text { Mean age (SD) } \\
\text { in years: } 4.36 \\
(1.6) \\
\text { Group } 1 \text { ( } \mathrm{n}= \\
\text { 16), } 7 \text { males } \\
\text { and } 9 \text { females } \\
\text { Group } 2 \text { ( } \mathrm{n}= \\
\text { 16), } 8 \text { males } \\
\text { and } 8 \text { females }\end{array}$ & $\begin{array}{l}\text { Group 1: } \\
\text { remifentanil (0.1 } \\
\mu \mathrm{g} / \mathrm{kg} / \mathrm{min})+\mathrm{mi}- \\
\text { dazolam (0.01 } \\
\mathrm{mg} / \mathrm{kg})+ \text { propo- } \\
\text { fol }(0.5 \mathrm{mg} / \mathrm{kg}) \\
\text { Group 2: } \mathrm{keta}- \\
\text { mine }(0.5 \mathrm{mg} / \mathrm{kg}) \\
+ \text { midazolam }(0.1 \\
\mathrm{mg} / \mathrm{kg})+ \text { propo- } \\
\text { fol }(0.5 \mathrm{mg} / \mathrm{kg}) \\
\text { All intravenous }\end{array}$ & $\begin{array}{l}\text { Bispectral In- } \\
\text { dex System } \\
\text { (BIS) } \\
\text { DSTG scale }\end{array}$ & $\begin{array}{l}\text { Significant difference ( } \mathrm{P}=0.003 \text { ) with } \\
\text { higher BIS values in Group } 1 \text { compared } \\
\text { to Group } 2 \\
\text { DSTG score noted at } 9 \text { different time in- } \\
\text { tervals was } 5 \text { (eyes closed, no response } \\
\text { to mild physical stimulus) in Group } 1 \\
\text { and Group } 2 \\
\text { Heart rate and respiratory rate showed } \\
\text { no significant difference between Group } \\
1 \text { and Group } 2 \text { ( } P=0.884, P=0.775 \text { re- } \\
\text { spectively) } \\
\text { Significant difference ( } P<0.001 \text { ) with } \\
\text { Group } 1 \text { having quicker recovery com- } \\
\text { pared to Group } 2 \text { ( } 9.23 \pm 2.77,30.83 \pm \\
5.96 \text { minutes) } \\
\text { Adverse effects: severe nausea and vom- } \\
\text { iting was reported in Group } 1, \text { number } \\
\text { not reported } \\
\text { Monitoring: heart rate, respiratory rate, } \\
\text { oxygen saturation }\end{array}$ & - \\
\hline
\end{tabular}

Midazolam (rectal) versus

\begin{tabular}{|c|c|c|c|c|c|}
\hline Jensen 1999 & $\begin{array}{l}\mathrm{n}=90 \\
\text { Median age } \\
\text { (age range) in } \\
\text { months and } \\
\text { gender: } \\
\text { Group } 1 \text { ( } \mathrm{n}= \\
\text { 45), } 32 \text { (18 to } \\
\text { 44), } 23 \text { males } \\
\text { and } 22 \text { females } \\
\text { Group } 2 \text { ( } \mathrm{n}= \\
\text { 45), }\end{array}$ & $\begin{array}{l}\text { Group 1: di- } \\
\text { azepam }(0.7 \mathrm{mg} / \\
\text { kg) } \\
\text { Group 2: mida- } \\
\text { zolam }(0.3 \mathrm{mg} / \\
\text { kg) } \\
\text { All rectal }\end{array}$ & $\begin{array}{l}\text { Wilton's seda- } \\
\text { tion scale } \\
\text { Acceptance } \\
\text { of treatment } \\
\text { (Holst) } \\
\text { Analysed us- } \\
\text { ing Wilcoxon } \\
\text { matched pair } \\
\text { test and Fish- } \\
\text { er's exact test }\end{array}$ & $\begin{array}{l}\text { No difference in acceptance of dental } \\
\text { procedures }(P=0.07) \\
\text { At } 1 \text { hour significantly more children } \\
\text { agitated in the diazepam group } 13 / 45 \\
(29 \%) \text { versus } 1 / 45(2 \%)(P=0.006) \\
\text { Data presented graphically } \\
\text { Adverse effects: lasting effect: aggres- } \\
\text { siveness, tiredness and unco-ordinated } \\
\text { movements in diazepam group, children } \\
\text { unusually quiet or lively on next day in } \\
\text { Group } 2\end{array}$ & $\begin{array}{l}\text { Some children } \\
\text { did not com- } \\
\text { plete treat- } \\
\text { ment how- } \\
\text { ever, it is not } \\
\text { possible to } \\
\text { extract exact } \\
\text { numbers as } \\
\text { these data } \\
\text { were only pre- } \\
\text { sented as bar } \\
\text { chart }\end{array}$ \\
\hline
\end{tabular}


Table 3. Drug comparison study outcomes (Continued)

29 (15 to 44 ),

23 males and

22 females

\begin{tabular}{|c|c|c|c|c|c|}
\hline \multicolumn{6}{|c|}{ Sevoflurane versus } \\
\hline Lahoud 2002 & $\begin{array}{l}\mathrm{n}=411 \\
\text { Mean age (SD) } \\
\text { in years: } \\
\text { Group } 1(\mathrm{n}= \\
\text { 170), } 6.2(1.9) \\
\text { Group } 2(\mathrm{n}= \\
241), 6(1.7)\end{array}$ & $\begin{array}{l}\text { Group 1: } 40: 60 \\
\text { nitrous ox- } \\
\text { ide/oxygen } \\
\text { Group 2: } 40: 60 \\
\text { nitrous ox- } \\
\text { ide/oxygen } \\
\text { + 0.1\%-0.3\% } \\
\text { sevoflurane } \\
\text { All inhalation }\end{array}$ & $\begin{array}{l}\text { Venham scale } \\
\text { level of seda- } \\
\text { tion and fail- } \\
\text { ure rate } \\
\text { Analysed us- } \\
\text { ing Mann- } \\
\text { Whitney U test } \\
\text { and Chi2 test }\end{array}$ & $\begin{array}{l}\text { Effective sedation: Group } 1215 / 241 \\
\text { (89\%); Group } 289 / 170(52 \%) ;(P< \\
0.0001) \\
\text { Venham scale - relaxed: Group } 1=32 \% \text {; } \\
\text { Group } 2=67 \% \\
\text { Significantly less failure in sevoflu- } \\
\text { rane/nitrous oxide } \\
\text { Group } 148 \% \text { failed ( }<<0.0001) ; \text { Group } 2 \\
11 \% \text { failed } \\
\text { Adverse effects: none mentioned } \\
\text { Monitoring: pulse oximeter, capno- } \\
\text { graph, pretracheal stethoscope, visual } \\
\text { assessment, auscultation and visualiza- } \\
\text { tion of chest movements }\end{array}$ & $\begin{array}{l}89 \% \text { sevoflu- } \\
\text { rane group } \\
\text { completed } \\
\text { treatment } \\
\text { compared to } \\
52 \% \text { of nitrous } \\
\text { oxide group }\end{array}$ \\
\hline Averley 2004a & $\begin{array}{l}\mathrm{n}=65 \\
\text { Gender, mean } \\
\text { weight (SD) in } \\
\mathrm{kg}, \text { mean age } \\
\text { (SD) in years: } \\
\text { Group 1: } 13 \\
\text { males and } 7 \\
\text { females, } 33.6 \\
(11.2), 9.3(2.2) \\
\text { Group 2: } 15 \\
\text { males and } 5 \\
\text { females, } 37.6 \\
\text { (14.6), } 9.6(2.3) \\
\text { Group 3: } 4 \\
\text { males and } 16 \\
\text { females, } 36.1 \\
\text { (11.8), } 9.9(2.2)\end{array}$ & $\begin{array}{l}\text { Group 1: midazo- } \\
\text { lam (0.5 mg/min) } \\
\text { (intravenous) + } \\
\text { air (nasal inhala- } \\
\text { tion) } \\
\text { Group 2: mi- } \\
\text { dazolam (0.5 } \\
\mathrm{mg} / \mathrm{min} \text { ) (in- } \\
\text { travenous) + } \\
\text { nitrous oxide } \\
\text { (40\%) (nasal in- } \\
\text { halation) } \\
\text { Group 3: mi- } \\
\text { dazolam (0.5 } \\
\text { mg/min) (intra- } \\
\text { venous) + nitrous } \\
\text { oxide ( } 40 \% \text { ) } \\
\text { (nasal inhala- } \\
\text { tion) + sevoflu- } \\
\text { rane (0.3\%) } \\
\text { (nasal inhala- } \\
\text { tion) }\end{array}$ & $\begin{array}{l}\text { Primary: com- } \\
\text { pletion of } \\
\text { treatment } \\
\text { Secondary: } \\
\text { level of co-op- } \\
\text { eration during } \\
\text { treatment, re- } \\
\text { covery time, } \\
\text { perception of } \\
\text { anxiety and } \\
\text { pain and par- } \\
\text { ent's satisfac- } \\
\text { tion } \\
\text { Analysed us- } \\
\text { ing Chi2 test }\end{array}$ & $\begin{array}{l}\text { Treatment completion: } \\
\text { Group 1: } 10 / 20(50 \%) \\
\text { Group 2: } 16 / 22(73 \%) \\
\text { Group 3: } 19 / 23(83 \%) \\
\text { (Chi² = 5.53, df = 2, P = 0.07) } \\
\text { Of the } 16 \text { treatment failures in Groups } 1 \\
\text { and } 2,9 \text { were subsequently successfully } \\
\text { treated with the addition of sevoflurane } \\
+ \text { nitrous oxide } \\
\text { No adverse effects reported } \\
\text { Monitoring: pulse oximeter, blood pres- } \\
\text { sure, ECG }\end{array}$ & - \\
\hline Averley 2004b & $\begin{array}{l}\mathrm{n}=664 \\
\text { Gender, mean } \\
\text { weight }(\mathrm{SD}) \text { in } \\
\mathrm{kg}, \text { mean age } \\
(\mathrm{SD}) \text { in years: } \\
\text { Group } 1 \text { ( } \mathrm{n}= \\
222), 81 \text { males, } \\
36.3(13.4), 9.1 \\
(2.7) \\
\text { Group } 2 \text { ( } \mathrm{n} \\
=306), 127\end{array}$ & $\begin{array}{l}\text { Group 1: midazo- } \\
\text { lam (0.5 mg/min) } \\
\text { (intravenous) + } \\
\text { air (nasal inhala- } \\
\text { tion) } \\
\text { Group 2: mi- } \\
\text { dazolam (0.5 } \\
\mathrm{mg} / \mathrm{min} \text { ) (in- } \\
\text { travenous) + } \\
\text { nitrous oxide } \\
\text { (40\%) (nasal in- } \\
\text { halation) }\end{array}$ & $\begin{array}{l}\text { Primary: com- } \\
\text { pletion of } \\
\text { treatment } \\
\text { Secondary: } \\
\text { level of co-op- } \\
\text { eration during } \\
\text { treatment, re- } \\
\text { covery time, } \\
\text { perception of } \\
\text { anxiety and } \\
\text { pain and par- }\end{array}$ & $\begin{array}{l}\text { Treatment completion: } \\
\text { Group 1: } 94 / 174(54 \%) \\
\text { Group 2: } 204 / 256(80 \%) \\
\text { Group 3: } 249 / 267(93 \%) \\
\text { Chi² = 9.64, df = 2, P<0.001 } \\
\text { Adverse effects: } 1 \text { faint in Group } 1,6 \\
\text { vomited in Group } 3\end{array}$ & - \\
\hline
\end{tabular}


Table 3. Drug comparison study outcomes (Continued)

\begin{tabular}{|c|c|c|}
\hline $\begin{array}{l}\text { males, } 37.8 \\
(14.1), 9.5(2.7)\end{array}$ & $\begin{array}{l}\text { Group 3: mi- } \\
\text { dazolam }(0.5\end{array}$ & $\begin{array}{l}\text { ent's satisfac- } \\
\text { tion }\end{array}$ \\
\hline $\begin{array}{l}\text { Group } 3(\mathrm{n} \\
=320), 103 \\
\text { males, } 37.7 \\
(14), 9.6(2.5)\end{array}$ & $\begin{array}{l}\mathrm{mg} / \mathrm{min} \text { ) (intra- } \\
\text { venous) + nitrous } \\
\text { oxide }(40 \%) \\
\text { (nasal inhala- } \\
\text { tion) + sevoflu- } \\
\text { rane }(0.3 \%) \\
\text { (nasal inhala- } \\
\text { tion) }\end{array}$ & $\begin{array}{l}\text { Analysed us- } \\
\text { ing Chi² test }\end{array}$ \\
\hline
\end{tabular}

Monitoring: pulse oximeter, blood pressure, ECG

AAPD = American Academy of Pediatric Dentistry; DSTG scale $=$ Dental Sedation Teachers Group scale; $d f=$ degrees of freedom; $E C G=$ electrocardiogram; $\mathrm{n}$ = number; $\mathrm{SD}$ = standard deviation; $\mathrm{SE}$ = standard error.

Table 4. Frequency of studies in which drug regimens were tested

\begin{tabular}{|c|c|}
\hline Drug regimen tested & Study frequency \\
\hline Chloral hydrate & 3 \\
\hline Chloral hydrate + hydroxyzine & 6 \\
\hline Chloral hydrate + hydroxyzine + midazolam & 1 \\
\hline Chloral hydrate + promethazine & 1 \\
\hline Dexmedetomidine & 2 \\
\hline Diazepam & 1 \\
\hline Hydroxyzine & 3 \\
\hline Ketamine & 7 \\
\hline Ketamine + promethazine & 1 \\
\hline Ketamine + midazolam & 3 \\
\hline Ketamine + midazolam + sevoflurane & 1 \\
\hline Melatonin & 1 \\
\hline Meperidine & 1 \\
\hline Meperidine + promethazine & 2 \\
\hline Midazolam & 27 \\
\hline Midazolam + acetaminophen & 1 \\
\hline Midazolam + fentanyl & 1 \\
\hline Midazolam + hydroxyzine & 1 \\
\hline Midazolam + nitrous oxide/oxygen & 1 \\
\hline
\end{tabular}


Table 4. Frequency of studies in which drug regimens were tested (Continued)

\begin{tabular}{|c|c|}
\hline Midazolam + ketamine & 5 \\
\hline Midazolam + sevoflurane + nitrous oxide/oxygen & 2 \\
\hline Midazolam + tramadol & 1 \\
\hline Nitrous oxide/oxygen & 5 \\
\hline Promethazine & 1 \\
\hline Propofol & 1 \\
\hline Sevoflurane + nitrous oxide/oxygen & 1 \\
\hline Sufentanil & 1 \\
\hline Tramadol & 1 \\
\hline Triazolam & 1 \\
\hline Triclofos & 2 \\
\hline Trimeprazine + methadone & 1 \\
\hline Trimeprazine + physeptone & 1 \\
\hline Zolpidem & 2 \\
\hline Zolpidem + tramadol & 1 \\
\hline
\end{tabular}

Table 5. Comparison of behaviour/sedation rating scales

\begin{tabular}{|c|c|c|c|c|}
\hline Score & Ramsay Sedation Scale & $\begin{array}{l}\text { Briekopf and But- } \\
\text { tner Emotional Sta- } \\
\text { tus Scale }\end{array}$ & $\begin{array}{l}\text { Frankl Behav- } \\
\text { iour Rating } \\
\text { Scale }\end{array}$ & Houpt Behaviour Rating Scale \\
\hline 1 & $\begin{array}{l}\text { Awake, anxious and agi- } \\
\text { tated, restless or both }\end{array}$ & $\begin{array}{l}\text { Irritated: awake, rest- } \\
\text { less, crying }\end{array}$ & Refusal/distress & Aborted: no treatment rendered \\
\hline 2 & $\begin{array}{l}\text { Awake, co-operative, ori- } \\
\text { entated, tranquil }\end{array}$ & Normal: awake, calm & $\begin{array}{l}\text { Unco-opera- } \\
\text { tive/reluctant }\end{array}$ & $\begin{array}{l}\text { Poor: treatment interrupted, only } \\
\text { partial treatment was completed }\end{array}$ \\
\hline 3 & $\begin{array}{l}\text { Awake responds to com- } \\
\text { mands only }\end{array}$ & $\begin{array}{l}\text { Inactive: tired, hardly } \\
\text { moving }\end{array}$ & $\begin{array}{l}\text { Co-operative/re- } \\
\text { served }\end{array}$ & $\begin{array}{l}\text { Fair: treatment interrupted but even- } \\
\text { tually completed }\end{array}$ \\
\hline 4 & Asleep, brisk response & $\begin{array}{l}\text { Sleepy: drowsy, with } \\
\text { reaction but rousable }\end{array}$ & $\begin{array}{l}\text { Interested/en- } \\
\text { joyed }\end{array}$ & $\begin{array}{l}\text { Good: difficult but all treatment was } \\
\text { performed }\end{array}$ \\
\hline 5 & $\begin{array}{l}\text { Asleep, sluggish re- } \\
\text { sponse }\end{array}$ & & & $\begin{array}{l}\text { Very good: some limited crying and } \\
\text { movement }\end{array}$ \\
\hline 6 & Asleep, no response & & & Excellent: no crying or movement \\
\hline
\end{tabular}

From Wan 2006. 
Table 6. Outcome measures used (excluding physiological parameters)

\begin{tabular}{|c|c|c|}
\hline Name & Studies used & Characteristics \\
\hline Houpt & $\begin{array}{l}\text { Avalos-Arenas 1998; } \\
\text { Bui 2002; Faytrouny } \\
\text { 2007; Gomes 2017; Lam } \\
\text { 2005; Malhotra 2016; } \\
\text { Meyer 1990; Mortaza- } \\
\text { vi 2009; Park 2006; Rai } \\
\text { 2007; Reeves 1996; } \\
\text { Sams 1993a; Shashiki- } \\
\text { ran 2006; Somri 2012; } \\
\text { Tyagi 2012; Wan } 2006\end{array}$ & $\begin{array}{l}\text { 3-point scale for sleep (awake to asleep); 4-point scale for movement ( } 1=\text { vi- } \\
\text { olent movement to } 4=\text { no movement); } 4 \text {-point scale for crying }(1=\text { hysterical } \\
\text { crying to } 4=\text { no crying); } 6 \text {-point scale for overall behaviour }(1=\text { no treatment } \\
\text { rendered to } 4=\text { difficult but all treatment completed to } 6=\text { excellent } / \text { no crying } \\
\text { or movement) }\end{array}$ \\
\hline Modified from Houpt & $\begin{array}{l}\text { Alfonzo-Echeverri 1993; } \\
\text { McKee } 1990\end{array}$ & $\begin{array}{l}\text { 4-point scale ranging from } 1=\text { treatment aborted, } 2=\text { poor (treatment fre- } \\
\text { quently interrupted), } 3=\text { fair (planned treatment completed), } 4=\text { good (all } \\
\text { treatment completed without crying or movement) }\end{array}$ \\
\hline Modified from Houpt & Lee-Kim 2004 & Modification not specified \\
\hline $\begin{array}{l}\text { Dichotomous behaviour } \\
\text { scale }\end{array}$ & $\begin{array}{l}\text { McKee 1990; Moore } \\
1984\end{array}$ & $\begin{array}{l}\text { Dichotomous behavioural scale rates specific events of treatment as satisfac- } \\
\text { tory or unsatisfactory }\end{array}$ \\
\hline $\begin{array}{l}\text { Ohio State University } \\
\text { Behavior Rating Scale }\end{array}$ & $\begin{array}{l}\text { Moreira 2013; Tor- } \\
\text { res-Perez } 2007\end{array}$ & 4-point scale ranging from quiet to crying and struggling \\
\hline Venham scale & $\begin{array}{l}\text { Lahoud 2002; Shanmu- } \\
\text { gaavel 2016a; Shan- } \\
\text { mugaavel 2016b; } \\
\text { Veerkamp } 1993\end{array}$ & 6 -point scale ranging from $0=$ relaxed to $5=$ out of control \\
\hline $\begin{array}{l}\text { Mental attitude, hyp- } \\
\text { notic effect, motor ac- } \\
\text { tivity and overall seda- } \\
\text { tion }\end{array}$ & Gallardo 1994 & $\begin{array}{l}\text { 2-point scale for mental attitude (relaxed or agitated); 3-point scale for hyp- } \\
\text { notic effect (asleep to or awake); 3-point scale for motor activity (absent to re- } \\
\text { markable); 3-point scale for sedation (excellent to unsatisfactory) }\end{array}$ \\
\hline $\begin{array}{l}\text { Ramsay Sedation Scale, } \\
\text { movement, crying, } \\
\text { overall sedation and } \\
\text { behaviour }\end{array}$ & $\begin{array}{l}\text { Aydintug 2004; Baygin } \\
\text { 2010; Isik 2008a; Isik } \\
\text { 2008b; Roelofse 1996a; } \\
\text { Roelofse 1998; Wan } \\
2006\end{array}$ & $\begin{array}{l}\text { 6-point scale for Ramsay (patient anxious and agitated to no response); 3- } \\
\text { point scale for movement (continuous movement to no movement); 4-point } \\
\text { scale for crying (hysterical crying to no weeping); 4-point scale for overall seda- } \\
\text { tion (impossible to very good) }\end{array}$ \\
\hline $\begin{array}{l}\text { Sedation scoring sys- } \\
\text { tem }\end{array}$ & Abrams 1993 & $\begin{array}{l}\text { 10-point scale ranging from } 1 \text { = unmanageable, unable to examine/treat, to } 10 \\
=\text { obtunded: apneic where } 5 \text { is ideal (well sedated, co-operative with normal } \\
\text { oximetry) }\end{array}$ \\
\hline $\begin{array}{l}\text { Sedation scoring sys- } \\
\text { tem }\end{array}$ & $\begin{array}{l}\text { Kapur 2004; Koirala } \\
2006\end{array}$ & 5-point scale ranging from asleep to awake \\
\hline $\begin{array}{l}\text { Sedation scoring sys- } \\
\text { tem }\end{array}$ & Roelofse 1996b & 4-point scale for level of sedation \\
\hline Wilton's sedation scale & Jensen 1999 & 4-point scale for Wilton (drowsy to agitated) \\
\hline $\begin{array}{l}\text { Acceptance of treat- } \\
\text { ment (Holst, 1987) }\end{array}$ & $\begin{array}{l}\text { Jensen 1999; McKee } \\
1990\end{array}$ & 4-point scale for Holst (positive to no) \\
\hline
\end{tabular}


Table 6. Outcome measures used (excluding physiological parameters) (Continued)

\begin{tabular}{|c|c|c|}
\hline $\begin{array}{l}\text { Acceptance of treat- } \\
\text { ment (Al Rakaf, 2001) }\end{array}$ & Shanmugaavel 2016b & 4-point scale \\
\hline Frankl & Kaviani 2015; Wan 2006 & 4-point scale for Frankl (definitely negative to definitely positive) \\
\hline $\begin{array}{l}\text { Modification Barker se- } \\
\text { dation scoring system, } \\
\text { overall quality sedation }\end{array}$ & Moody 1986 & $\begin{array}{l}\text { Barker sedation score calculated by summing scores given at intervals } \\
\text { throughout the treatment; 4-point rating scale for sedation quality (poor to ex- } \\
\text { cellent) }\end{array}$ \\
\hline $\begin{array}{l}\text { Global rating scale of } \\
\text { overall behaviour }\end{array}$ & McKee 1990 & 5 ratings from excellent to poor-aborted \\
\hline Sedation rating scale & Singh 2002 & 7-point scale ranging from sleep to excited \\
\hline Brietkopf and Buttner & Wan 2006 & 4-point scale ranging from irritated to sleepy \\
\hline Fukuta & Shashikiran 2006 & 7-point scale ranging from asleep to violent rejection \\
\hline Sedation rating scale & Bhatnagar 2012 & 8-point scale ranging from sleep to excited \\
\hline $\begin{array}{l}\text { Modified scale to classi- } \\
\text { fy behaviour/response } \\
\text { to treatment/sedation }\end{array}$ & Özen 2012 & 4-point scale ranging from success to not accepting treatment \\
\hline $\begin{array}{l}\text { Behaviour/response to } \\
\text { treatment rating scale }\end{array}$ & Surendar 2014 & 5-point scale ranging from excellent to prohibitive \\
\hline $\begin{array}{l}\text { Modified Dental Seda- } \\
\text { tion Teachers Groups } \\
\text { Scale (Ransford, 2010) }\end{array}$ & Kaviani 2015 & $\begin{array}{l}\text { 4-point scale measuring operating conditions ranging from } 1=\text { good to } 4=\mathrm{im} \text { - } \\
\text { possible }\end{array}$ \\
\hline
\end{tabular}

\section{AP PE N D I C E S}

\section{Appendix 1. Cochrane Oral Health's Trials Register search strategy}

From January 2017, searches of the Cochrane Oral Health's Trials Register for this review were undertaken using the Cochrane Register of Studies and the search strategy below:

1. ((sedation or sedative* or "pre anesthetic medication" or "pre anaesthetic medication" or hypnotic* or "anti anxiety agent*" or barbiturate* or benzodiazepine* or "relative analgesia" or "nitrous oxide" or "nitrous-oxide" or midazolam or diazepam or "chloral hydrate" or hydroxyzine or temazepam or ketamine or meperidine or promethazine or triazolam or trimeprazine or metaclopramide or flunitrazepam or sevoflurane)) AND (INREGISTER)

2. ((anxiety or anxious or fear ${ }^{\star}$ or fright ${ }^{\star}$ or distress ${ }^{\star}$ or phobi ${ }^{\star}$ or uncopoperative or un-cooperative or un-cooperative)) AND (INREGISTER)

3. ((child* or infant $^{\star}$ or adolescen* ${ }^{\star}$ R pediatric* or paediatric $\left.\left.{ }^{\star}\right)\right)$ AND (INREGISTER)

4. \#1 and \#2 and \#3 (INREGISTER)

Previous searches were undertaken using the Procite software, and the search strategy below:

((sedation or sedative* or "pre anesthetic medication" or "pre anaesthetic medication" or hypnotic* or "anti anxiety agent " or barbiturate* or benzodiazepine* or "relative analgesia" or "nitrous oxide" or "nitrous-oxide" or midazolam or diazepam or "chloral hydrate" or hydroxyzine or temazepam or ketamine or meperidine or promethazine or triazolam or trimeprazine or metaclopramide or flunitrazepam or sevoflurane) OR (anxiety or anxious or fear ${ }^{\star}$ or fright* or distress* or phobi* or uncopoperative or un-cooperative or un-cooperative) AND (child* or infant* or adolescen* OR pediatric* or paediatric $\left.{ }^{\star}\right)$ )

\section{Appendix 2. Cochrane Central Register of Controlled Trials (CENTRAL) search strategy}

\#1 MeSH descriptor Oral Surgical Procedures explode all trees 
\#2 MeSH descriptor Tooth explode all trees

\#3 (dental ${ }^{\star}$ or dentist* or oral) and (surgery or surgical or orthodont ${ }^{\star}$ or endodont ${ }^{\star}$ or pulpot ${ }^{\star}$ or carie* or carious)

\#4 ((dental or tooth or teeth) and (filling* or restor ${ }^{\star}$ or extract $^{\star}$ or treat $\left.^{\star}\right)$ )

\#5 (\#1 OR \#2 OR \#3 OR \#4)

\#6 MeSH descriptor Conscious Sedation, this term only

\#7 MeSH descriptor Preanesthetic Medication, this term only

\#8 ("preanesthetic medication" or "preanaesthetic medication")

\#9 sedat*

\#10 MeSH descriptor Hypnotics and Sedatives explode all trees

$\# 11 \mathrm{MeSH}$ descriptor Anti-Anxiety Agents explode all trees

\#12 MeSH descriptor Barbiturates explode all trees

\#13 MeSH descriptor Benzodiazepines explode all trees

\#14 "relative analgesia"

\#15 MeSH descriptor Anxiety, this term only

\#16 MeSH descriptor Dental Anxiety, this term only

\#17 ((anxiety or anxious or fear ${ }^{\star}$ or fright ${ }^{\star}$ or stress ${ }^{\star}$ or distress ${ }^{\star}$ or phobi $^{\star}$ or uncooperative or un-cooperative or unco-operative) and (dental ${ }^{\star}$ or dentist*))

\#18 ("nitrous oxide" or midazolam or diazepam or "chloral hydrate" or hydroxyzine or temazepam or ketamine or meperidine or promethazine or triazolam or trimeprazine or metaclopramide or flunitrazepam or sevoflurane)

\#19 (\#6 OR \#7 OR \#8 OR \#9 OR \#10 OR \#11 OR \#12 OR \#13 OR \#14 OR \#15 OR \#16 OR \#17 OR \#18)

\#20 MeSH descriptor Child explode all trees

\#21 MeSH descriptor Infant, this term only

\#22 MeSH descriptor Adolescent, this term only

\#23 pediatric* or paediatric*

$\# 24$ child $^{\star}$ or infant* ${ }^{\star}$ or adolescent ${ }^{\star}$

\#25 (\#20 OR \#21 OR \#22 OR \#23 OR \#24)

\#26 (\#5 AND \#19 AND \#25)

\section{Appendix 3. MEDLINE Ovid search strategy}

1. exp Oral Surgical Procedures/

2. exp tooth/

3. ((((dental\$ or dentist\$ or oral) adj4 surgery) or oral) adj4 surgical\$) or orthodont\$ or endodont\$ or pulpot\$ or carie\$ or carious).mp.

[mp=title, original title, abstract, name of substance word, subject heading word]

4. ((dental or tooth or teeth) or (filling\$ or restor\$ or extract\$ or treat\$)).mp. [mp=title, original title, abstract, name of substance word,

subject heading word]

5. or/1-4

6. Conscious sedation/

7. Preanesthetic medication/

8. (preanesthetic medication or preanaesthetic medication).mp. [mp=title, original title, abstract, name of substance word, subject heading word]

9. sedat\$.mp. [mp=title, original title, abstract, name of substance word, subject heading word]

10. exp "Hypnotics and Sedatives"/

11. exp Anti-Anxiety Agents/

12. exp Barbiturates/

13. exp Benzodiazepines/

14. relative analgesia.mp. [mp=title, original title, abstract, name of substance word, subject heading word]

15. Anxiety/

16. Dental anxiety/

17. ((anxiety or anxious or fear $\$$ or fright\$ or stress\$ or distress\$ or phobi\$ or uncooperative or un-cooperative or unco-operative) and (dental\$ or dentist\$)).mp. [mp=title, original title, abstract, name of substance word, subject heading word]

18. (nitrous oxide or midazolam or diazepam or chloral hydrate or hydroxyzine or temazepam or ketamine or meperidine or promethazine or triazolam or trimeprazine or metaclopramide or flunitrazepam or sevoflurane).mp. [mp=title, original title, abstract, name of substance word, subject heading word]

19. or/6-18

20. $\exp$ Child/

21. Infant/

22. Adolescent/

23. (pediatric or paediatric).mp. [mp=title, original title, abstract, name of substance word, subject heading word]

24. (child\$ or infant\$ or adolescen\$).mp. [mp=title, original title, abstract, name of substance word, subject heading word]

25. or/20-24

26. 5 and 19 and 25 
This subject search was linked to the Cochrane Highly Sensitive Search Strategy (CHSSS) for identifying randomised trials in MEDLINE: sensitivity-maximising version (2008 revision) as referenced in Chapter 6.4.11.1 and detailed in box 6.4.c of theCochrane Handbook for Systematic Reviews of Interventions, Version 5.1.0 (updated March 2011) (Lefebvre 2011).

1. randomized controlled trial.pt.

2. controlled clinical trial.pt.

3. randomized.ab.

4. placebo.ab.

5. drug therapy.fs.

6. randomly.ab.

7. trial.ab.

8. groups.ab.

9. or/1-8

10. exp animals/ not humans.sh.

11.9 not 10

\section{Appendix 4. Embase Ovid}

1. exp Oral Surgical Procedures/

2. exp Tooth/

3. (((((dental\$ or dentist\$ or oral) adj4 surgery) or oral) adj4 surgical\$) or orthodont\$ or endodont\$ or pulpot\$ or carie\$ or carious).mp.

4. ((dental or tooth or teeth) and (filling\$ or restor\$ or extract\$ or treat\$)).mp.

5. or/1-4

6. Conscious sedation/

7. Preanesthetic medication/

8. ("preanesthetic medication" or "preanaesthetic medication").mp.

9. sedat\$.mp.

10. exp "Hypnotics and Sedatives"/

11. exp Anti-Anxiety Agents/

12. exp Barbiturates/

13. exp Benzodiazepines/

14. "relative analgesia".mp.

15. Anxiety/

16. Dental anxiety/

This subject search was linked to an adapted version of the Cochrane Centralised Search Project filter for identifying randomised controlled trials in Embase Ovid (see www.cochranelibrary.com/help/central-creation-details.html for information):

1. Randomized controlled trial/

2. Controlled clinical study/

3. Random\$.ti,ab.

4. randomization/

5. intermethod comparison/

6. placebo.ti,ab.

7. (compare or compared or comparison).ti.

8. ((evaluated or evaluate or evaluating or assessed or assess) and (compare or compared or comparing or comparison)).ab.

9. (open adj label).ti,ab.

10. ((double or single or doubly or singly) adj (blind or blinded or blindly)).ti,ab.

11. double blind procedure/

12. parallel group $\$ 1 . t i, a b$.

13. (crossover or cross over).ti,ab.

14. ((assign\$ or match or matched or allocation) adj5 (alternate or group\$1 or intervention $\$ 1$ or patient $\$ 1$ or subject $\$ 1$ or participant

\$1)).ti,ab.

15. (assigned or allocated).ti,ab.

16. (controlled adj7 (study or design or trial)).ti,ab.

17. (volunteer or volunteers).ti,ab.

18. trial.ti.

19. or/1-18

20. (exp animal/ or animal.hw. or nonhuman/) not (exp human/ or human cell/ or (human or humans).ti.)

21. 19 not 20 


\section{Appendix 5. US National Institutes of Health Ongoing Trials Register (ClinicalTrials.gov) search strategy}

sedation and child ${ }^{*}$ and dental

\section{Appendix 6. World Health Organization International Clinical Trials Registry Platform search strategy} sedation and child* and dental

\section{WHAT'S NEW}

\begin{tabular}{lll}
\hline Date & Event & Description \\
\hline 22 February 2018 & $\begin{array}{l}\text { New citation required and conclusions } \\
\text { have changed }\end{array}$ & $\begin{array}{l}\text { Changes to author byline. Review update including 14 new stud- } \\
\text { ies bringing the total to 50 included studies. Methods updated. } \\
\text { 'Summary of findings' tables included. Slight change to review's } \\
\text { conclusions. }\end{array}$ \\
\hline 22 February 2018 & New search has been performed & Searches updated to February 2018. \\
\hline
\end{tabular}

\section{H I S T O R Y}

Protocol first published: Issue 4, 2002

Review first published: Issue 2, 2005

\begin{tabular}{lll}
\hline Date & Event & Description \\
\hline 13 January 2012 & $\begin{array}{l}\text { New citation required and conclusions } \\
\text { have changed }\end{array}$ & $\begin{array}{l}\text { Major revision to tables and text including addition of meta- } \\
\text { analysis of oral midazolam and use of forest plots as another way } \\
\text { of displaying data. } \\
\text { Susan Furness now added as author. } \\
\text { All cross-over studies removed from the review and 11 new stud- } \\
\text { ies added. }\end{array}$ \\
\hline 13 January 2012 & New search has been performed & Searches updated to August 2011. \\
\hline 28 July 2008 & Amended & Converted to new review format. \\
\hline 15 November 2005 & New citation required but conclusions & Substantive amendment. \\
\hline
\end{tabular}

\section{CONTRIBUTIONS OF AUTHORS}

- Paul F Ashley contributed to all aspects of this review, in particular data extraction, analysis and interpretation of data and entering data into Review Manager.

- Mohsin Chaudhary contributed to all aspects of this review, in particular data extraction, interpretation of data and entering data into Review Manager.

- Liege Lourenço-Matharu contributed to all aspects of this review, in particular data collection and interpretation of data.

\section{DECLARATIONS OF INTEREST}

Paul F Ashley: no interests to declare.

Mohsin Chaudhary: no interests to declare.

Liege Lourenço-Matharu: no interests to declare. 


\section{SOURCES OF SUPPORT}

\section{Internal sources}

- Eastman Dental Institute, UK.

\section{External sources}

- National Institute for Health Research (NIHR), UK.

This project was supported by the NIHR, via Cochrane Infrastructure funding to Cochrane Oral Health. The views and opinions expressed herein are those of the review authors and do not necessarily reflect those of the Systematic Reviews Programme, the NIHR, the NHS or the Department of Health.

- Cochrane Oral Health Global Alliance, Other.

The production of Cochrane Oral Health reviews has been supported financially by our Global Alliance since 2011 (oralhealth.cochrane.org/partnerships-alliances). Contributors over the past year have been the American Association of Public Health Dentistry, USA; AS-Akademie, Germany; the British Association for the Study of Community Dentistry, UK; the British Society of Paediatric Dentistry, UK; the Canadian Dental Hygienists Association, Canada; the Centre for Dental Education and Research at All India Institute of Medical Sciences, India; the National Center for Dental Hygiene Research \& Practice, USA; New York University College of Dentistry, USA; NHS Education for Scotland, UK; and the Swiss Society for Endodontology, Switzerland.

\section{DIFFERENCES BETWEEN PROTOCOLAND REVIEW}

Cross-over trials are now excluded from this review, as they are not an appropriate study design when the intervention can have a long lasting effect (Higgins 2011). The relationship between pain and anxiety is well established, it is clear that the child's experience of any procedure will have an impact on any subsequent one (Shashikiran 2006).

\section{INDEX TERMS}

\section{Medical Subject Headings (MeSH)}

Analgesics, Non-Narcotic [administration \& dosage]; Anti-Anxiety Agents [administration \& dosage] [*therapeutic use]; Chloral Hydrate [administration \& dosage]; Dental Anxiety [*drug therapy]; Dental Care for Children [methods] [* psychology]; Hydroxyzine [administration \& dosage]; Hypnotics and Sedatives [administration \& dosage] [^therapeutic use]; Meperidine [administration \& dosage]; Midazolam [administration \& dosage]; Nitrous Oxide [administration \& dosage]; Preanesthetic Medication [methods]; Randomized Controlled Trials as Topic

\section{MeSH check words}

Child; Humans 